DOE/NV/11432-74

UC721

\title{
SITE CHARACTERIZATION AND MONITORING DATA FROM AREA 5 PILOT WELLS \\ NEVADA TEST SITE \\ NYE COUNTY, NEVADA
}

By

Special Projects Section

Environmental Restoration \& Technology Development Department

Environmental Management Division

Reynolds Electrical \& Engineering Co., Inc.

February 1994

Work performed under contract

No. DE-AC08-94-NV11432

Prepared by

Reynolds Electrical \& Engineering Co., Inc.

P.O. Box 98521

Las Vegas, Nevada 89193-8521 


\section{DISCLAIMER}

This report was prepared as an account of work sponsored by an agency of the United States Government. Neither the United States Government nor any agency Thereof, nor any of their employees, makes any warranty, express or implied, or assumes any legal liability or responsibility for the accuracy, completeness, or usefulness of any information, apparatus, product, or process disclosed, or represents that its use would not infringe privately owned rights. Reference herein to any specific commercial product, process, or service by trade name, trademark, manufacturer, or otherwise does not necessarily constitute or imply its endorsement, recommendation, or favoring by the United States Government or any agency thereof. The views and opinions of authors expressed herein do not necessarily state or reflect those of the United States Government or any agency thereof. 


\section{DISCLAIMER}

Portions of this document may be illegible in electronic image products. Images are produced from the best available original document. 


\section{DISCLAIMER}

The enclosed document has not received any secondary reviews by the U.S. Department of Energy's Office of Scientific and Technical Information (OSTI) for public releasability Post 9/11. It is being made available with the understanding that any further distribution, beyond the requesting organization, is the responsibility of the receiving organization/individual. Any distribution outside the DOE community may require additional reviews by the originating site in compliance with Secretary Abraham's May 30, 2002, memorandum titled "Safeguarding Information Pertaining to Weapons of Mass Destruction and Other Sensitive Information." 


\section{TABLE OF CONTENTS}

EXECUTIVE SUMMARY . .....................

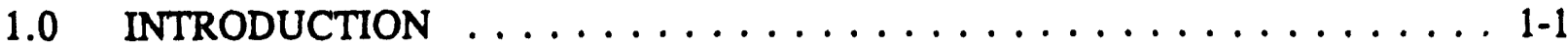

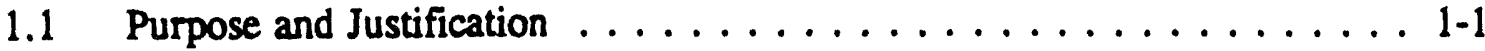

1.2 Scope of Report ........................

1.3 Overview of Activities $\ldots \ldots \ldots \ldots \ldots \ldots \ldots \ldots \ldots \ldots$

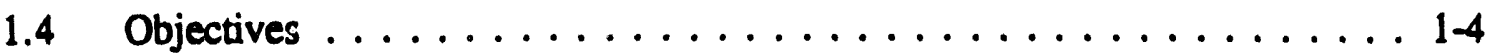

1.5 Site Description $\ldots \ldots \ldots \ldots \ldots \ldots \ldots \ldots \ldots \ldots \ldots \ldots$

1.6 Pilot Well Locations . . . . . . . . . . . . . . . . 1-6

1.7 Site Climate and Meteorology $\ldots \ldots \ldots \ldots \ldots \ldots \ldots \ldots \ldots$

2.0 DRILLING, CORING, AND COMPLETION $\ldots \ldots \ldots \ldots \ldots \ldots$ 2-1

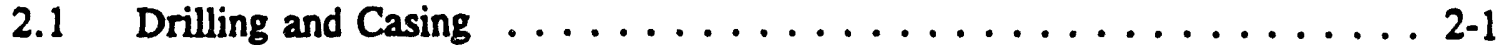

2.2 Collection of Geologic Samples . . . . . . . . . . . . 2-4

2.2.1 Collection of Core Samples . . . . . . . . . . . 2-5

2.2.2 Collection of Drill Cuttings Samples . . . . . . . . . 2-8

2.3 Geologic Description and Disposition of Samples . . . . . . . . 2-8

2.3.1 Handling, Description, and Disposition of Core Samples . . . . 2-8

2.3.2 Handling, Description, and Disposition of Drill Cuttings Samples . 2-9

2.4 Field Tests on Core and Drill Cuttings Samples . . . . . . . . . . . 2-9

2.4.1 $\mathrm{SF}_{6}$ Tracer Tests for Estimating Disturbance from

Air Drilling Fluid . . . . . . . . . . . . . . . 2-9

2.4.2 Radiological Surveys of Geologic Samples . . . . . . . 2-11

2.5 Pilot Well Completion . . . . . . . . . . . . . . . . 2-12

2.5.1 Subsurface Completion Design . . . . . . . . . . 2-12

2.5.2 Subsurface Completion Operations .............. 2-16

2.5.3 Surface Facilities and Wellhead Completion ... . . . . 2-17

2.6 Well Development . . . . . . . . . . . . . . . . 2-17

3.0 LABORATORY TESTING METHODS AND RESULTS . . . . . . . . . . . . 3-1

3.1 General Geologic Description, Lithology, Stratigraphy,

Mineralogy and Organic Matter . . . . . . . . . . . . . . . . 3-1

3.1.1 General Geologic, Lithologic, and Stratigraphic

Data for Alluvium . . . . . . . . . . . . . . 3-13

3.1.2 Tuff Lithology and Stratigraphy $\ldots \ldots \ldots \ldots \ldots \ldots \ldots$. . . . . . . . .

3.1.3 Mineralogy . . . . . . . . . . . . . . . . 3-16

3.1.4 Secondary Mineralogy and Organic Matter . . . . . . . . . 3-17

3.2 Physical Properties . . . . . . . . . . . . . . . . . . 3-25

3.2.1 Particle Size Distribution . . . . . . . . . . . 3-25 


\section{TABLE OF CONTENTS (Continued)}

Page

3.2.2 Bulk Density and Porosity . . . . . . . . . . . . . . . . . . 3-29

3.3 Hydrologic Properties . . . . . . . . . . . . . . . . . 3-34

3.3.1 Saturated Hydraulic Conductivity . . . . . . . . . . . . 3-34

3.3.2 Moisture Retention Relations ... . . . . . . . . . . . 3-34

3.3.3 Unsaturated Hydraulic Conductivity . . . . . . . . . . . . . 3-39

3.4 Hydrologic Conditions . . . . . . . . . . . . . . . . . 3-41

3.4 .1 Water Content . . . . . . . . . . . . . . . . . . . 3-41

3.4 .2 Water Potential ... . . . . . . . . . . . . . . 3-49

3.5 Environmental Tracers ..................... 3-51

3.5.1 Chloride/Bromide Profiles ................. 3-51

3.5 .2 Stable Isotope Profiles . . . . . . . . . . . . . . . . . 3-60

3.5.3 Cosmogenic Chlorine-36 Data . . . . . . . . . . . . 3-60 3- . . . . . .

3.5 .4 Soluble Sulfate . . . . . . . . . . . . . . . . . . . . . . . . 3-64

3.6 Sampling and Analysis of Core Samples for Hazardous and Radiological

Parameters . . . . . . . . . . . . . . . . . . . . 3-66

4.0 FIELD TESTING METHODS AND RESULTS . . . . . . . . . . . . . . 4-1

4.1 Preliminary Surface Surveys of Potential Contaminants at Drill Sites . . 4-1

4.1.1 Surface Soil Sampling, Analysis, and Results . . . . . . . . . . 4-1

4.1.2 Near-Surface Radon and Tritium Gas Sampling,

Analysis, and Results . . . . . . . . . . . . . . . . . . . 4-2

4.1.2.1 Radon Soil Gas Surveys . . . . . . . . . . . 4-2 . . . . . . . .

4.1.2.2 Tritium Soil Gas Surveys ... . . . . . . . 4-2

4.2 Surface Geophysical Surveys . . . . . . . . . . . . . . . . . . . 4-3

4.2.1 Resistivity Surveys . . . . . . . . . . . . . . . . . . . . . 4-4

4.2 .2 Magnetic Surveys . . . . . . . . . . . . . . . . . . . . 4-6

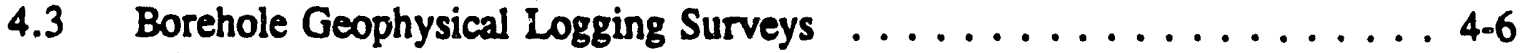

4.3.1 Description of Borehole Logging Activities . . . . . . . . . . . . . 4-6

4.3.2 Summary of Nuclear Logging Results . . . . . . . . . . . . . 4-8

4.3.3 Summary of Borehole Deviation Logs . . . . . . . . . . . . . . 4-9

4.4 In Situ Air Permeability Testing . . . . . . . . . . . . . . . . . . . 4-10

4.4.1 Air (Injection) Permeability Tests Below Drill Casing . . . . . . 4-10

4.4.2 Post Drilling Air (Injection) Permeability Testing . . . . . . . . . . 4-11

4.5 Upper Aquifer Hydraulic Parameter Testing . . . . . . . . . . . . . . 4-12

4.5.1 Water Table Elevations and Gradient . . . . . . . . . . . . 4-12 . . . . . 4-14

4.5.2 Hydraulic Conductivity Recovery Tests . . . . . . . . . . . . . 4-14

4.6 Neutron Logging Calibration Boreholes .............. . . 4-15

5.0 UPPER AQUIFER WATER QUALITY . . . . . . . . . . . . . . . 5-1

5.1 RCRA Groundwater Sampling and Analysis . . . . . . . . . . . . 5-1

5.2 Preliminary Comparison of General Water Chemistry ... . . . . . . . 5-3 
TABLE OF CONTENTS (Continued)

Page

6.0 PRELIMINARY VADOSE ZONE MONITORING DATA $\ldots \ldots \ldots \ldots$ 6-1

6.1 Temperature Profile Data . . . . . . . . . . . . . . 6-1

6.2 Formation Air Pressure Profile Data ..............6-1

6.3 Water Potential Profile Data ................. 6-3

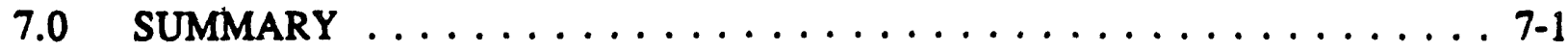

8.0 REFERENCES $\ldots \ldots \ldots \ldots \ldots \ldots \ldots \ldots \ldots \ldots \ldots \ldots \ldots \ldots$ 8-1

Errata to the Pilot Well Report Appendix

Addenda to the Pilot Well Report Appendix 


\section{LIST OF FIGURES}

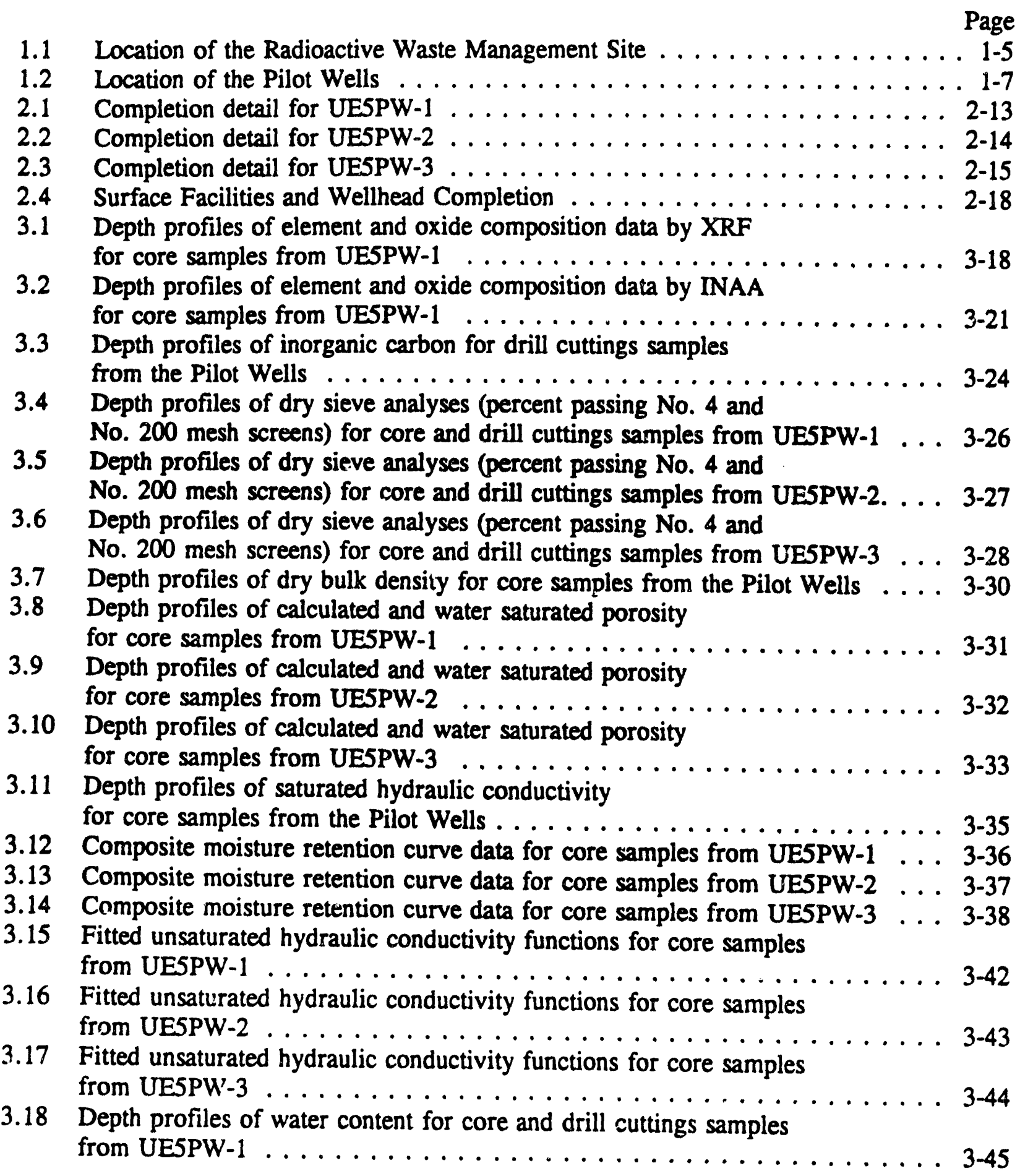




\section{LIST OF FIGURES (Continued)}

3.19 Depth profiles of water content for core and drill cuttings samples from UESPW-2 . . . . . . . . . . . . . . . 3-46

3.20 Depth profiles of water content for core and drill cuttings samples from UESPW $-3 \ldots \ldots \ldots \ldots \ldots \ldots \ldots \ldots$. . . . . . . . . .

3.21 Depth profiles of water content for core samples from the Pilot Wells . . . . 3 3-48

3.22 Depth profiles of water potential for core samples from the Pilot Wells . . . . 3-50

3.23 Depth profiles of dry soil chloride concentrations for drill cuttings samples from the Pilot Wells $\ldots \ldots \ldots \ldots \ldots \ldots \ldots$ 3-53

3.24 Depth profiles of dry soil chloride concentrations for core samples from the Pilot Wells . . . . . . . . . . . . . 3-54

3.25 Depth profiles of dry soil bromide concentrations for drill cuttings samples from the Pilot Wells $\ldots \ldots \ldots \ldots \ldots \ldots \ldots$ 3-55

3.26 Depth profiles of dry soil bromide concentrations for core samples from the Pilot Wells . . . . . . . . . . . . 3-56

3.27 Depth profiles of dry soil chloride/bromide ratios

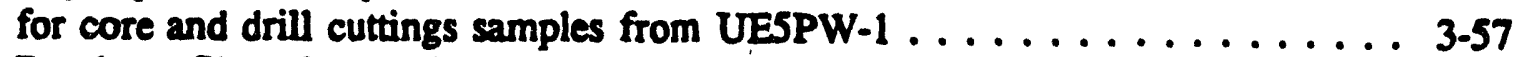

3.28 Depth profiles of dry soil chloride/bromide ratios for core and drill cuttings samples from UESPW-2 $\ldots \ldots \ldots \ldots \ldots \ldots 3-58$

3.29 Depth profiles of dry soil chloride/bromide ratios for core and drill cuttings samples from UESPW-3 . . . . . . . . . . . . 3-59

3.30 Depth profiles of stable isotopes for core samples from the Pilot Wells $\ldots \ldots$. . . 3-61

3.31 Comparison of measured stable isotopes for core and water samples from the Pilot Wells with stable isotope data for the global Meteoric Water Line (MWL) 3-62

3.32 Depth profile of ${ }^{36} \mathrm{Cl} / \mathrm{Cl}$ ratios for core samples from UESPW-1 . . . . . . 3-63

3.33 Depth profiles of soluble sulfate for drill cuttings samples from the Pilot Wells 3-65

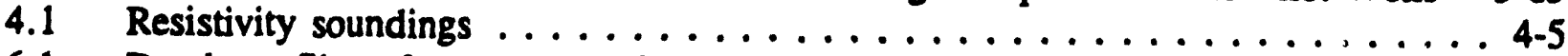

6.1 Depth profiles of temperature from the Pilot Wells ............. $6-2$

6.2 Depth profiles of in situ psychrometer data from the Pilot Wells $\ldots \ldots \ldots .66-4$ 


\section{LIST OF TABLES}

1.1. Page

1.1 Regulatory drivers for site characterization and monitoring . . . . . . . . . 1-2

1.2 Nevada State Central Zone coordinates for the Pilot Wells . . . . . . . . . . 1-7

2.1 Standard Operating Procedures (SOPs) and Test Plans (TPs) applicable to the Pilot Well Project $\ldots \ldots \ldots \ldots \ldots \ldots \ldots \ldots \ldots \ldots \ldots \ldots .2$

2.2 Summary of Pilot Well drilling lithology information $\ldots \ldots \ldots \ldots \ldots . \ldots 2-3$

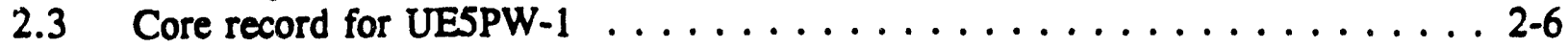

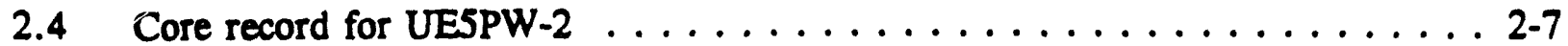

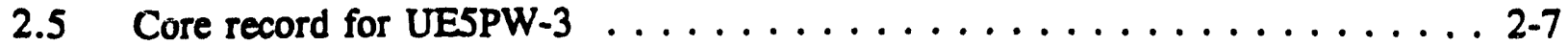

2.6 Definitions of core and drill cuttings sample labels . . . . . . . . 2-10

2.7 Pilot Well development data $\ldots \ldots \ldots \ldots \ldots \ldots \ldots \ldots \ldots \ldots . \ldots \ldots$

3.1 Summary of laboratory methods $\ldots \ldots \ldots \ldots \ldots \ldots \ldots \ldots \ldots \ldots . \ldots \ldots$ 3-2

3.2 Summary of tests performed on samples from the Pilot Wells . . . . . . . 3-4

3.3 Summary of descriptive statistics of alluvium samples from the Pilot Wells . . . 3-5

3.4 Summary of descriptive statistics of tuff samples from UESPW-3 . . . . . . 3-12

3.5 Summary of USCS group names for core and drill cuttings samples from the Pilot Wells . . . . . . . . . . . . . . . 3-14

3.6 Summary of descriptive statistics of moisture retention curves for core samples from the Pilot Wells $\ldots \ldots \ldots \ldots \ldots \ldots . . \ldots 3-40$

4.1 Borehole geophysicai logging episodes in the Pilot Wells . . . . . . . . . 4-7

4.2 Uncorrected water table elevation data . . . . . . . . . . . . . . . 4-13

5.1 Testing laboratories, chemical parameters, and analytical methods $\ldots \ldots \ldots$ 5-2 


\section{LIST OF APPENDICES}

A Drilling Information

A.1 Chronological Drilling Summary for UE5PW-1

A.2 Chronological Drilling Summary for UESPW-2

A.3 Chronological Drilling Summary for UE5PW-3

A.4 Drilling Penetration Rate Data for Pilot Wells

B Core and Drill Cuttings Sample Description Data

B.1 Borehole Log Sheets for UESPW-1

B.2 Borehole Log Sheets for UESPW-2

B.3 Borehole Log Sheets for UESPW-3

B.4 Drill Cuttings Log Data for UESPW-1

B.5 Drill Cuttings Log Data for UE5PW-2

B.6 Drill Cuttings Log Data for UE5PW-3

C Tracer $\left(\mathrm{SF}_{6}\right)$ Test Data

C.1 UESPW-1 SF 6 Data from Core Samples and Compressor Air Lines

C.2 Formation $\mathrm{SF}_{6}$ Tracer Gas Concentrations

D Completion Data

D.1 Pilot Well Completion

D.1.1 Annular Materials

D.1.2 Preparation for Completion

D.1.3 Casing and Instrumentation Installation Detail

D.1.4 Stemming Detail

D.1.5 Completion Operations Safety

D.2 Pilot Well Stemming Summaries

D.2.1 UESPW-1 Stemming Summary

D.2.2 UESPW-2 Stemming Summary

D.2.3 UESPW-3 Stemming Summary

D.3 Pilot Well Casing Tallies

D.3.1 UE5PW-1 Casing Tally

D.3.2 UE5PW-2 Casing Tally

D.3.3 UE5PW-3 Casing Tally

D.4 Pilot Well Daily Activities

D.4.1 UESPW-1 Daily Activity

D.4.2 UE5PW-2 Daily Activity

D.4.3 UE5PW-3 Daily Activity 


\section{LIST OF APPENDICES (Continued)}

E Laboratory Testing Data of Geologic Samples

E.1 Stratigraphy and Mineralogy Data

E.1.1 Profiles of USCS Textural Classes

E.1.2 XRF and INAA Data

E.1.2.1 Oxide Composition Data Determined by Major Elements XRF and INAA Methods for Core Samples for UE5PW-1

E.1.2.2 Elemental Composition Data Determined by INAA and Trace Element XRF Methods for Core Sampling from UE5PW-1

E.1.2.3 Oxide Composition Data Determined by Major Elements XRF and INAA Methods for Core Samples for UESPW-2

E.1.2.4 Elemental Composition Data Determined by INAA and Trace Element XRF Methods for Core Sampling from UESPW-2

E.1.2.5 Oxide Composition Data Determined by Major Elements XRF and INAA Methods for Core Samples for UESPW-3

E.1.2.6 Elemental Composition Data Determined by INAA and Trace Element XRF Methods for Core Sampling from UESPW-3

E.2 Material, Hydrologic, and Geochemical Parameter Data for Alluvial Samples

E.2.1 Results of Laboratory Tests for Core Samples from UESPW-1

E.2.2 Results of Laboratory Tests for Core Samples from UESPW-2

E.2.3 Results of Laboratory Tests for Core Samples from UE5PW-3

E.2.4 Results of Laboratory Tests for Drill Cuttings Samples from UESPW-1

E.2.5 Results of Laboratory Tests for Drill Cuttings Samples from UESPW-2

E.2.6 Results of Laboratory Tests for Drill Cuttings Samples from UESPW-3

E.2.7 Moisture Retention Data for Core Samples from UE5PW-1

E.2.8 Moisture Retention Data for Core Samples from UE5PW-2

E.2.9 Moisture Retention Data for Core Samples from UESPW-3

E.2.10 Parameters Required to Calculate Unsiturated Hydraulic Conductivities for Core Samples

E.3 Material, Hydrologic, and Geochemical Parameter Data for Tuff Samples

E.3.1 Results of Laboratory Tests for Tuff Core Samples from UESPW-3

E.3.2 Results of Laboratory Tests for Tuff Drill Cuttings Samples UE5PW-3

E.4 Results of Sampling and Analysis for Hazardous and Radiological Parameters in core samples

F Field Test Data

F.1 Near-Surface Soil Gas Surveys

F.1.1 Surface Soil Sampling, Analysis, and Results

F.1.2 Near-Surface Radon and Tritium Gas Sampling, Analysis, and Results

F.2 Surface Geophysical Surveys

F.2.1 Resistivity Survey Data

F.2.2 Magnetic Survey Data 


\section{LIST OF APPENDICES (Continued)}

F.3 Borehole Geophysical Surveys

F.3.1 Description of Borehole Geophysical Logging Tools Used

F.3.2 Borehole Geophysical Logs Run in UESPW-1 on 4/20/92

F.3.3 Borehole Geophysical Logs Run in UESPW-1 on 6/16/92

F.3.4 Borehole Deviation Logs Run in UE5PW-1 on 2/24/93

F.3.5 Borehole Geophysical Logs Run in UESPW-2 on 7/20/92

F.3.6 Borehole Geophysical Logs Run in UESPW-2 on 9/28/92 and 9/29/92

F.3.7 Borehole Deviation Logs Run in UESPW-2 on 2/25/93

F.3.8 Borehole Geophysical Logs Run in UESPW-3 on 9/28/92

F.3.9 Borehole Geophysical Logs Run in UESPW-3 on 11/18/92

F.3.10 Borehole Deviation Logs Run in UESPW-3 on 2/25/93

F.4 In Situ Air Permeability Testing Data

F.4.1 Dimensions of Air Permeability Testing Interval for the Pilot Wells

F.4.2 In Situ Air Permeability Testing Data

F.4.3 Effective Air Permeabilities and Inertial Coefficients for Field Testing in The Pilot Wells

F.5 Upper Aquifer Hydraulic Parameter Testing

F.5.1 Estimating the Water Table Slope under the Area 5 RWMS

F.5.2 Results of Hydraulic Conductivity Recovery Tests

G Data from Neutron Logging Calibration Boreholes

G.1 Drilling Information

G.1.1 Chronological Drilling Summary for UESPW-2A, 2B, and 2C

G.1.2 Core Record for UESPW-2A, 2B, and 2C

G.1.3 Nevada State Central Zone Coordinates for Neutron Logging Calibration Boreholes

G.2 Core and Drill Cuttings Sample Description Data

G.2.1 Borehole Log Sheets for UESPW-2A

G.2.2 Borehole Log Sheets for UESPW-2B

G.2.3 Borehole Log Sheets for UESPW-2C

G.2.4 Drill Cuttings Log Data for UESPW-2A

G.2.5 Drill Cuttings Log Data for UESPW-2B

G.2.6 Drill Cuttings Log Data for UESPW-2C

G.3 Laboratory Testing Data of Geologic Samples

G.3.1 Stratigraphy and Mineralogy Data

G.3.1.1 Surnmary of USCS Group Names for Core and Drill Cuttings Samples from Calibration Boreholes

G.3.1.2 Results from XRF and INAA for Core Samples from UESPW-2A

G.3.1.3 Results from XRF and INAA for Core Samples from UESPW-2B

G.3.1.4 Results from XRF and INAA for Core Samples from UESPW-2C 


\section{LIST OF APPENDICES (Continued)}

G.3.2 Material, Hydrologic, and Geochemical Parameter Data

G.3.2.1 Results of Laboratory Tests for Core Samples from UESPW-2A

G.3.2.2 Results of Laboratory Tests for Core Samples from UESPW-2B

G.3.2.3 Results of Laboratory Tests for Core Samples from UESPW-2C

G.3.2.4 Results of Laboratory Tests for Drill Cuttings Samples from UESPW-2A

G.3.2.5 Results of Laboratory Tests for Drill Cuttings Samples from UESPW-2B

G.3.2.6 Results of Laboratory Tests ior Drill Cuttings Samples from UESPW-2C

G.3.2.7 Summary of Descriptive Statistics of Alluvial Samples from UESPW-2A, UESPW-2B, and UESPW-2C

\section{G.4 Field Test Data}

G.4.1 Site Preparation Information

G.4.2 Neutron-Moisture Meter Data

G.4.2.1 Neutron-Moisture Meter Data for UE5PW-2A

G.4.2.2 Neutron-Moisture Meter Data for UESPW-2B

G.4.2.3 Neutron-Moisture Meter Data for UESPW-2C

G.4.3 Calibration of the Neutron-Moisture Meter in the Calibration Boreholes

H Upper Aquifer Water Quality Data

H.1 Upper Aquifer Water Quality Data

H.2 Preliminary General Water Chemistry

I Vadose Zone Calibration and Monitoring Data

I.1 Thermistor Calibration Data

1.2 Preliminary Temperature Monitoring Data

1.3 Pressure Transducer Calibration Data

I.4 Preliminary Pressure Monitoring Data

I.5 Thermocouple Psychrometer Calibration Data 


\section{LIST OF ACRONYMS}

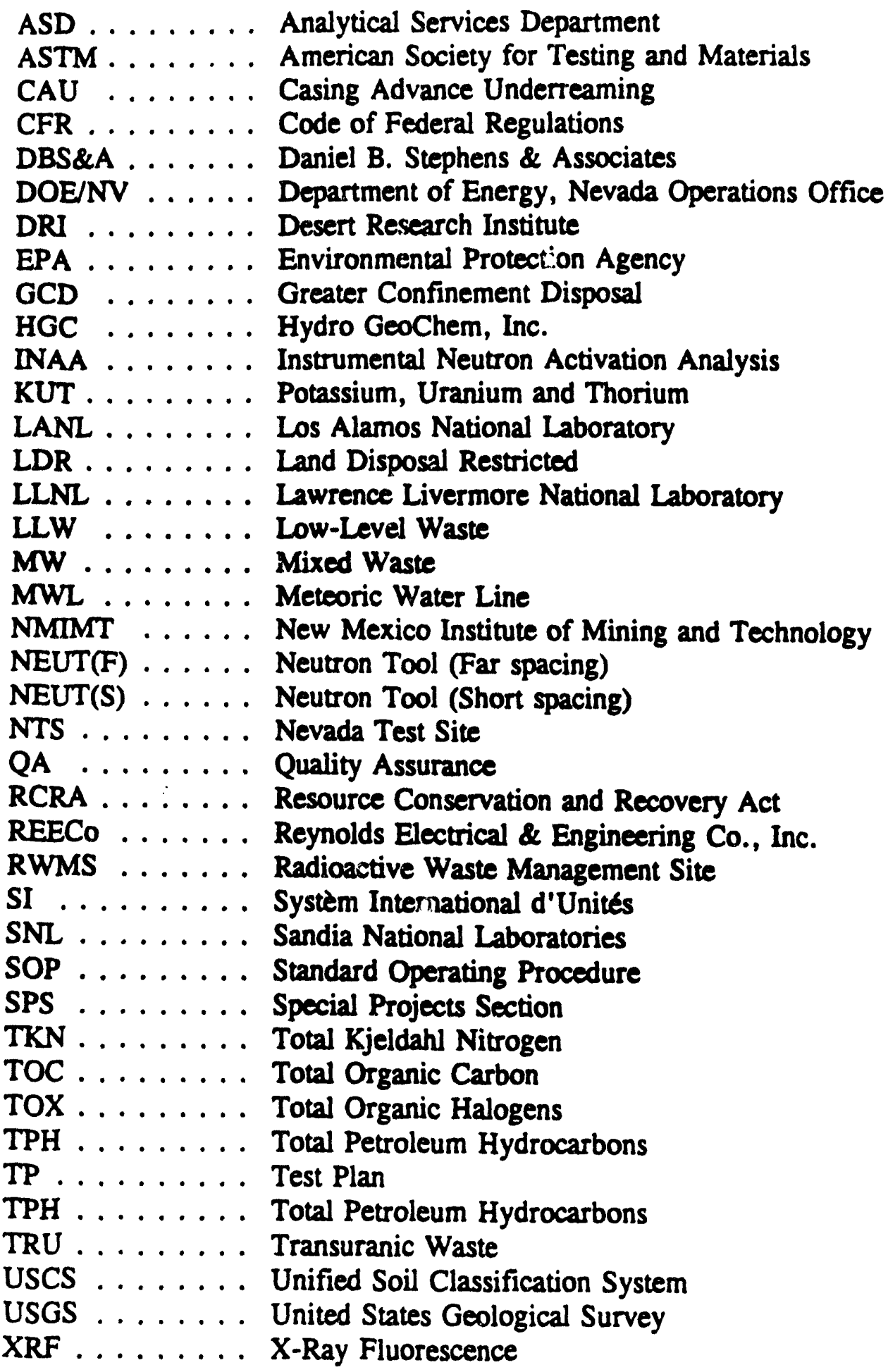




\section{EXECUTIVE SUMMARY}

Three exploratory boreholes (Pilot Wells) have been drilled and completed to the uppermost aquifer in Area 5 of the Nevada Test Site, Nye County, Nevada, at the behest of the U.S. Department of Energy. These exploratory Pilot Wells are part of the Area 5 Site Characterization Program developed to meet data needs associated with regulatory requirements applicable to the disposal of low-level, mixed, and high-specific activity waste at this site. This series of boreholes was specifically designed to characterize the hydrogeology of the thick vadose zone and to help define the water quality and hydraulic properties of the uppermost aquifer.

Wells UESPW-1, UESPW-2, and UESPW-3 are located in a triangular array near the southeast, northeast, and northwest corners, respecticely, of the approximately $2.6-\mathrm{km}^{2}$ (1-mi $\left.{ }^{2}\right)$ Area 5 Radioactive Waste Management Site to give reasonable spatial coverage for sampling and characterization and to help define the nearly horizontal water table. Two of the wells, UESPW-1 and UESPW-2, penetrated only unconsolidated alluvial materials and the third well, located closer to the margin of the basin, penetrated both alluvium and underlying ash-flow and bedded tuff units.

The results of laboratory testing of core and drill cuttings samples indicate that the mineralogical, material, and hydrologic properties of the alluvial deposits are very similar within and between boreholes. For example, the thick alluvial deposits have a remarkably sinilar lithologic composition; they are virtually free of layers of secondary carbonate; they are primarily coarse-grained sands and gravels with generally less than 10 percent fines; and have porosities, saturated hy-draulic conductivities, moisture retention relations, and unsaturated hydraulic conductivities that are typical of coarse-grained material.

Additional tests on the same core and drill cuttings samples indicate that hydrologic conditions within these alluvial deposits are also similar between Pilot Wells. Both core and drill cuttings samples are dry (less than 10 percent water content by weight) throughout the entire unsaturated section of alluvium, and water content increases slightly with depth in each Pilot Well. Water potential measurements on core samples show a large positive potential gradient (water tends to move upward, rather than downward) to a depth of approximately $30.5 \mathrm{~m}$ (100 ft) in each borehole, and a nearly zero potential gradient throughout the remaining portion of the vadose zone.

These hydrologic condition data and hydrologic property data indicate that little net downward liquid flow is occurring (if any) through the thick vadose zone. Conversely, gas flow by diffusion, and possibly by advection, may be an important transport mechanism.

The limited data collected from the tuff units underlying the alluvium, below a depth of approximately $188 \mathrm{~m}(617.5 \mathrm{ft})$ in UE5PW-3, indicate that they have properties similar to those previously reported for these units. 
Environmental tracer measurements made on water extracted from geologic samples support the conclusion that little, if any, liquid water movement is occurring in the vadose zone. These measurements included chloride and bromide, stable isotopes of hydrogen and oxygen, and cosmogenic chlorine-36. More specifically, these data strongly suggest that water vapor in the upper portion of the vadose zone is moving upward in response to evaporative demand of the present arid climate. Moreover, water in the vadose zone at depths on the order of several hundred meters probably infiltrated under a much wetter climate.

Preliminary water quality data from each Pilot Well indicate that key hazardous and radioactive constituents do not exceed appropriate standards in the uppermost aquifer. Further, the uppermost water table gradient is nearly horizontal, as found in previous studies.

Finally, vadose zone monitoring instruments and equipment, that were stemmed in place around the central monitoring well casing in each Pilot Well, are being used to make in situ measurements of key hydrologic and pneumatic parameters and to monitor changes in these parameters over time. 


\subsection{INTROD'JCTION}

The Special Projects Section (SPS) of Reynolds Electrical \& Engineering Co., Inc. (REECo) is responsible for characterizing the subsurface geology and hydrology of the Area 5 Radioactive Waste Management Site (RWMS) at the Nevada Test Site (NTS) for the U.S. Department of Energy, Nevada Operations Office (DOE/NV), Environmental Restoration and Waste Management Division, Waste Operations Branch. The three Pilot Wells that comprise the Pilot Well Project are an important part of the Area 5 Site Characterization Program designed to determine the suitability of the Area 5 RWMS for disposal of low-level waste (LLW), mixed waste (MW), and transuranic wastc (TRU).

\subsection{Purpose and Justification}

The primary purpose of the Pilot Well Project is two-fold: first, to characterize important water quality and hydrologic properties of the uppermost aquifer; and second, to characterize the lithologic, stratigraphic, and hydrologic conditions which influence infiltration, redistribution, and percolation, and chemical transport through the thick vadose zone in the vicinity of the Area 5 RWMS. The justification for this work comes from the state of Nevada review of the original DOE/NV Resource Conservation and Recovery Act (RCRA) Part B Permit application submitted in 1988 for disposal of mixed waste at the Area 5 RWMS. The state of Nevada determined that the permit was deficient in characterization data conceming the hydrogeology of the vadose zone and the water quality and hydraulic properties of the uppermost aquifer. DOE/NV agreed with the State and proposed the Pilot Well Project to satisfy these important site characterization data requirements. In addition, DOE/NV proposed to install and monitor vadose zone instruments to obtain baseline unsaturated hydraulic parameter data in these Pilot Wells.

A number of federal regulations and DOE Orders provide additional justification for the site characterization and baseline monitoring data collection activities incorporated in the Pilot Well Project. These regulations include specific RCRA requirements for the land disposal of hazardous waste, requirements for obtaining waivers relating to the land disposal of hazardous waste, as well as DOE Order 5820.2A "Radioactive Waste Management" and 40 Code of Federal Regulations (CFR) 191 requirements for land disposal of radioactive waste. Regulatory requirements for characterization and baseline monitoring are summarized in Table 1.1 for different waste types that DOE/NV is currently or may someday consider disposing of at the Area 5 RWMS.

\subsection{Scope of Report}

This report describes Pilot Well drilling and coring, geophysical logging, instrumentation and stemming, laboratory testing, and in situ testing and monitoring activities. In addition, this 
Table 1.1 Regulatory drivers for site characterization and monitoring.

\begin{tabular}{|c|c|c|c|c|c|c|}
\hline \multirow{2}{*}{ Requirement } & \multicolumn{6}{|c|}{ Waste and Faciliay Comegory } \\
\hline & $\begin{array}{l}\text { Low-Level } \\
\text { Waste }\end{array}$ & $\begin{array}{l}\text { Mixed Waste } \\
\text { (new cello) }\end{array}$ & $\begin{array}{l}\text { Mixed Waste } \\
\text { (exiting cellu) }\end{array}$ & $\begin{array}{l}\text { LD, Mixed Wane } \\
\text { (no treatment } \\
\text { available) }\end{array}$ & $\begin{array}{l}\text { TRU a Onphan } \\
\text { Mixed Waste } \\
\text { (new OCD cella) }\end{array}$ & $\begin{array}{l}\text { TRU \& Orphan } \\
\text { Mixed Waxte } \\
\text { (eximing GCD cello) }\end{array}$ \\
\hline \multicolumn{7}{|l|}{ DOE Order $5820.2 A$} \\
\hline Performance assessment & $\begin{array}{l}\text { Characterization } \\
\text { and Monitorine }\end{array}$ & $\begin{array}{l}\text { Characterization } \\
\text { and Monitoring }\end{array}$ & $\begin{array}{l}\text { Chancterization } \\
\text { and Monitoring }\end{array}$ & $\begin{array}{l}\text { Characterization } \\
\text { and Moniloring }\end{array}$ & $\begin{array}{l}\text { Characterization } \\
\text { and Monitorings }\end{array}$ & $\begin{array}{l}\text { Characterization } \\
\text { and Monitoring }\end{array}$ \\
\hline \multicolumn{7}{|l|}{ RCRA (Pant B Permit) } \\
\hline $\begin{array}{l}\text { Releasea from solid waste } \\
\text { management unit ( } 40 \mathrm{CFR} \\
264.90-101)^{1}\end{array}$ & $\mathbf{N} / \mathbf{A}$ & Monitoring & N/A & $\mathbf{N} / \mathbf{A}$ & Monitoring & N/A \\
\hline $\begin{array}{l}\text { Groundweter monitoring } \\
\text { waiver ( } 40 \text { CFR 264.90(b)(2))' }\end{array}$ & $\mathbf{N} / \mathbf{A}$ & $\mathbf{N} / \mathbf{A}$ & Characterization & $\mathbf{N} / \mathbf{A}$ & N/A & Monitoring \\
\hline $\begin{array}{l}\text { No miznation variance } \\
(40 \mathrm{CFR} 268.6(0))^{2}\end{array}$ & N/A & $\mathbf{N} / \mathbf{A}$ & $\mathbf{N} / \mathbf{A}$ & $\begin{array}{l}\text { Charseterization } \\
\text { ad Monitoring }\end{array}$ & $\begin{array}{l}\text { Characterization } \\
\text { and Monitorine }\end{array}$ & $\begin{array}{l}\text { Characterization } \\
\text { and Monitoring }\end{array}$ \\
\hline $\begin{array}{l}\text { Exemption for liner and } \\
\text { LCRS/LDCRS' ( } 40 \text { CFR } \\
264.301(b, d))^{4}\end{array}$ & $\mathbf{N} / \mathbf{A}$ & Chaneterization & $\mathbf{N} / \mathbf{A}$ & $\mathbf{N} / \mathbf{A}$ & N/A & $\mathbf{N} / \mathbf{A}$ \\
\hline Proposed 40 CFR 193" & & & $\mathbf{N} / \mathbf{A}$ & $\mathbf{N} / \mathbf{A}$ & $\mathbf{N} / \mathbf{A}$ & N/A \\
\hline Groundwater protection & $\begin{array}{l}\text { Characterization } \\
\text { and Monilorine }\end{array}$ & N/A & & & & \\
\hline $\begin{array}{l}40 \text { CFR 191' (vacated } \\
\text { and remanded) }\end{array}$ & & & & & & \\
\hline Performance assesament & $\mathbf{N} / \mathbf{A}$ & $\mathbf{N} / \mathbf{A}$ & N/A & $\mathbf{N} / \mathbf{A}$ & $\begin{array}{l}\text { Chancterization } \\
\text { and Monitoring }\end{array}$ & $\begin{array}{l}\text { Characterization } \\
\text { and Monitoring }\end{array}$ \\
\hline
\end{tabular}

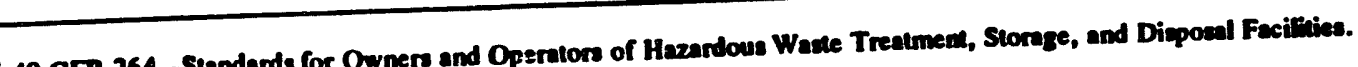

I 40 CFR 264-Standands for Owners and O

240 CFR 268-Land Disposal Restrictions

- CCRS/LCRS: Leachate Collection and Removal System/Leachate Detection, Collection, and Removal Sysem

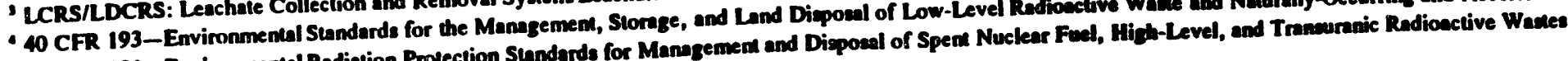

40 CFR $191-$ 
report summarizes all data obtained from these activities up to April 23, 1993. Data collected either from site characterization or baseline monitoring after this date will be included in annual Pilot Well data reports.

This report does not present detailed analyses and/or interpretations of the data. This will be presented in separate reports that are being developed for submittal to peer-reviewed professional joumals. This present report is designed to be a repository of methods and data which are as complete and detailed as possible, and which can be referenced by interpretative peer-reviewed professional journal publications. Also note, this report presents the data in le System International d'Unites (SI) system of units while the data in the Appendices have not been converted to this format.

\subsection{Overview of Activities}

Each Pilot Well was drilled and cored from the ground surface to approximately $21.3 \mathrm{~m}$ $(70 \mathrm{ft})$ below the water table. Total depths of the Pilot Wells ranged from approximately 256 to $292 \mathrm{~m}$ (840 to $955 \mathrm{ft}$ ). The drilling was accomplished using a casing-advance underreaming (CAU) in situ hydraulic conditions (water content and water potential) of the formation and drill cuttings. Core samples were collected in alluvium by driving a solid tube (containing segmented Lexan liners) into the formation ahead of the casing with an airpercussion hammer. Standard air-rotary coring methods were used to core the underlying tuff formation in UESPW-3.

Cuttings were collected at $0.76-\mathrm{m}(2.5-\mathrm{ft})$ intervals and cores were taken at selected intervals. The lithology of the drill cuttings and core was rapidly described in the field before samples were packaged to maintain their physical integrity and to minimize water loss by evaporation. Samples were then shipped to various testing laboratories or stored for future use. Laboratory tests were conducted on both drill cuttings and core samples to quantify the distribution with depth of hydrologic, geochemical, environmental tracer, and mineralogic parameters. These laboratory data will provide estimates of input parameters required to model liquid, vapor, and heat flow and some of the parameters required to model solute transport both in the vadose zone and the upper regions of the deep alluvial aquifer. Finally, both environmental tracer and unsaturated hydrologic parameters will be used to calculate recharge and travel times to the water table.

Borehole geophysical logging was performed during selected stages of drilling to attempt to make in situ measurements of key physical and hydrologic parameters. These logs were intended to support and possibly augment the data obtained from geologic cuttings samples.

Upon completion of drilling, monitoring well casing and vadose zone instruments were installed and stemmed in place. In situ hydrologic tests were conducted in the completed boreholes to characterize air and liquid permeabilites. In addition, monitoring the vadose zone with instruments (including thermocouple psychrometers, thermistors, and air pressure 
transducers) was initiated. Finally, each Pilot Well was developed and purged, and water quality samples were collected to measure general water quality parameters and concentrations of hazardous and radioactive constituents.

\subsection{Objectives}

The specific objectives of the Pilot Well Project were:

- To collect sufficient core samples required to meet geologic, hydrologic, geochemical, and hazardous constituent characterization objectives as specified below.

- To determine the stratigraphic, lithologic, mineralogic, physical, and magnetic characteristics of geologic samples to define vadose zone and groundwater flow paths.

- To determine the hydrologic characteristics (hydrologic properties and conditions) in geologic core samples and in situ formation materials to help delineate both vadose zone and groundwater flow paths.

- To measure environmental tracer concentrations and hydraulic parameters in geologic samples necessary to estimate recharge.

- To characterize the geochemical properties of geologic samples required to model the transport of contaminants.

- To measure concentrations of potential source term radionuclides and RCRA hazardous constituents in both geologic and groundwater samples to establish baseline conditions.

- To delineate the general background chemical composition of the uppermost aquifer to establish baseline conditions.

- To determine the extent to which drilling fluids have invaded geologic core samples and in situ formation materials.

\subsection{Site Description}

The NTS is a DOE facility occupying approximately $3,500 \mathrm{~km}^{2}\left(1,350 \mathrm{mi}^{2}\right)$ in southern Nevada, approximately $105 \mathrm{~km}(65 \mathrm{mi})$ northwest of Las Vegas (Figure 1.1). The site is bordered to the north, west, and east by the Nellis Air Force Range, a government-owned, restricted access area. Activities at the NTS include a variety of nuclear and non-nuclear projects and experiments. 


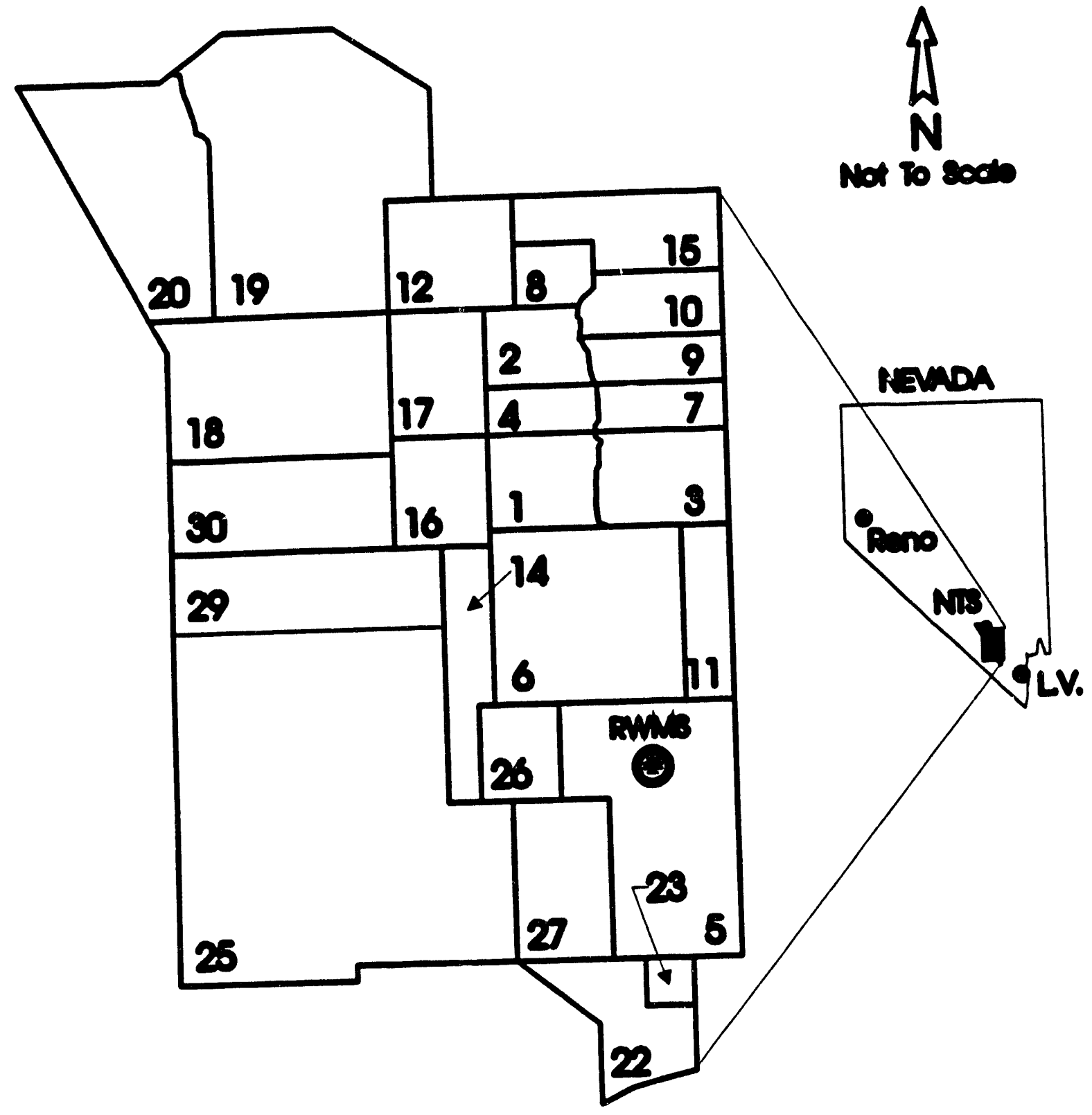

Figure 1.1 Location of the Area 5 Radioactive Waste Management Site. 
The Area 5 RWMS encompasses $3.0 \mathrm{~km}^{2}$ (740 acres) north of Frenchman Flat and is located near the junction of three alluvial fans within the Frenchman Lake drainage basin (Dozier and Rawlinson, 1991). The Low-level Waste Management Unit is a 0.39-km² (96-acre) facility located in the southeast section of the Area 5 RWMS. It was established in 1978 for the purpose of disposing of LLW generated at the NTS and other DOE facilities.

The Area 5 RWMS currently accepts low-level radioactive waste for shallow land burial. In the past, mixed wastes have been accepted for shallow land burial and high-specific-activity waste have been disposed of in $36.6 \mathrm{~m}$ (120 ft) deep augered shafts. These shafts are called the Greater Confinement Disposal (GCD) shafts. Most wastes are disposed of in steel drums, steel boxes, or wooden boxes. DOE/NV has accepted low-level mixed waste containing hazardous constituents that are not land disposal restricted (LDR), and plans are being made to resume accepting this type of mixed waste in the near future. In addition, DOE/NV plans to develop the capability to dispose of low-level LDR mixed waste that does not meet treatment standards.

\subsection{Pilot Well Locations}

The locations of the three Pilot Wells are outside past, current, and future waste disposal areas and are shown in Figure 1.2. In plan view, the wells are located approximately at the apexes of an equilateral triangle with sides approximately $1,500 \mathrm{~m}(1 \mathrm{mi})$ in length. These locations were selected to facilitate measurement of the expected very small water table gradient. UESPW-2 and UESPW-3 were positioned on the expected up-gradient side of the Area 5 RWMS to attempt to resolve questions concerning the effect of the Massachusetts Mountains on the uppermost aquifer groundwater gradient.

UE5PW-1 and UE5PW-2 were both located on older pediment surfaces where early stages of desert pavement have developed. UESPW-3 is located on a much younger alluvial fan. The Nevada State Central Zone Coordinates of the boreholes and elevations above sea level are given in Table 1.2.

\subsection{Site Climate and Meteorology}

The climate and meteorology of the region is typical of the upper Mojave Desert province. Two major air movement patterns affect this area: from fall through spring, the efffects of the Pacific high-pressure area moving over the Sierra Nevada are dominant; in summer, this high-pressure area dissipates, and the warm moist air mass in the Gulf of Mexico exerts its influence. Average daily temperatures range from $2^{\circ} \mathrm{C}\left(36^{\circ} \mathrm{F}\right)$ in January to $24^{\circ} \mathrm{C}\left(75^{\circ} \mathrm{F}\right)$ in August. Precipitation is highly variable in the desert. The summer months have intense, isolated thunderstorms and the winter storms are of longer duration and lower intensity. The average precipitation is approximately $100 \mathrm{~mm}(4 \mathrm{in})$ per year and the estimated evapotranspiration rate is $2,200 \mathrm{~mm}$ (87 in) per year (EG\&G/SAIC, 1991). 


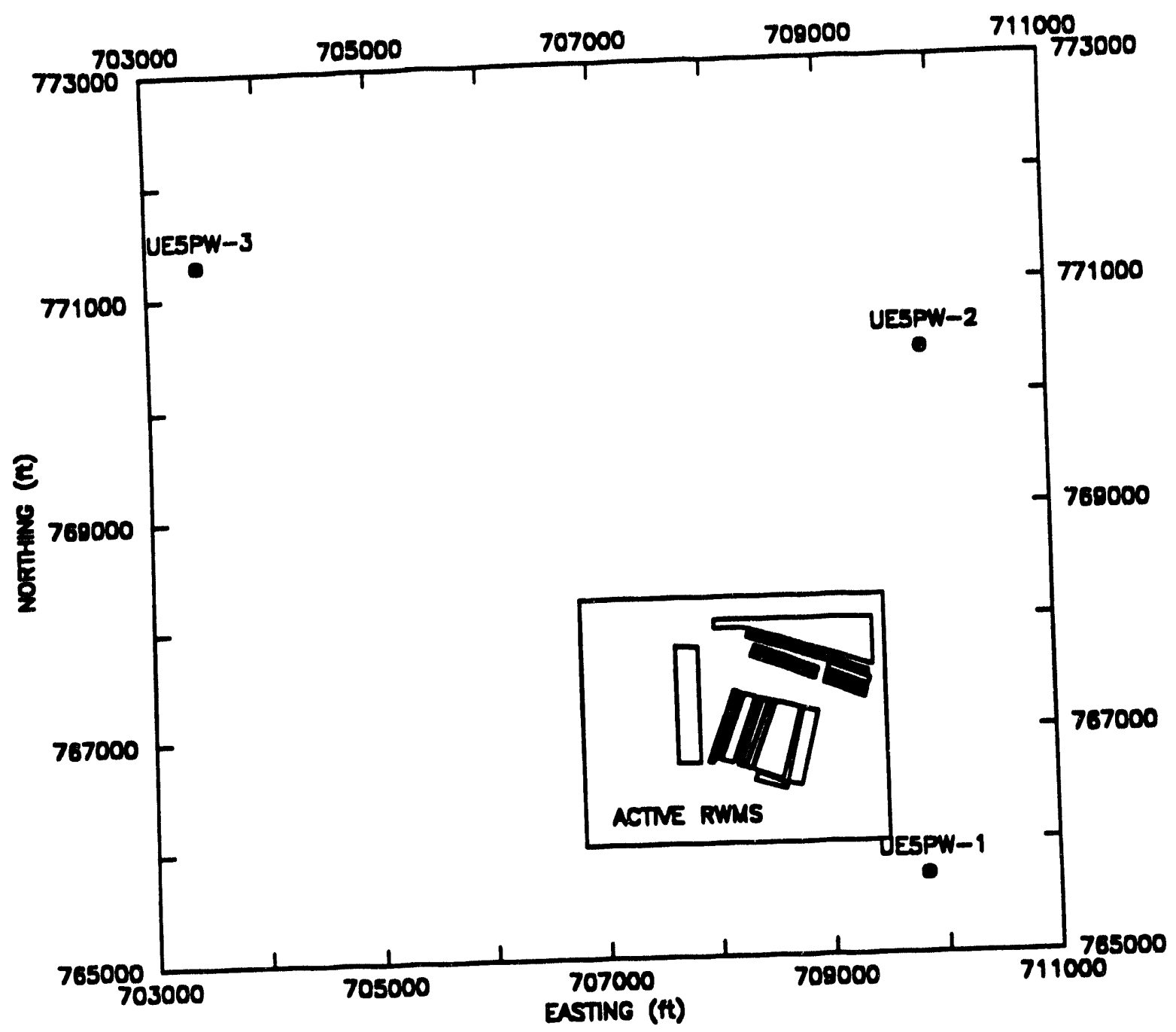

Figure 1.2 Location of the Pilot Wells.

Table 1.2 Nevada state Central zone coordinates for the Pilot Wells.

\begin{tabular}{|c|c|c|c|}
\hline & Elevation Above & Nevada state Central & zone Coordinates \\
\hline Borehole & $\begin{array}{c}\text { Sea Level } \\
\mathrm{m} \text { (ft) }\end{array}$ & North $m(f t)$ & East $m(f t)$ \\
\hline UESPW-1 & $\begin{array}{c}969.37 \\
(3.180 .35) \\
\end{array}$ & $\begin{array}{r}223,386.48 \\
(765,702.19) \\
\end{array}$ & $\begin{array}{c}216,357.08 \\
(709,831.57) \\
\end{array}$ \\
\hline UE5PW-2 & $\begin{array}{c}990.12 \\
(3.248 .42) \\
\end{array}$ & $\begin{array}{r}234,817.13 \\
(770,395.90) \\
\end{array}$ & $\begin{array}{c}216,376.00 \\
(709,893.63) \\
\end{array}$ \\
\hline UE5PW-3 & $\begin{array}{c}1,005.22 \\
(3,297.97)\end{array}$ & $\begin{array}{c}235,089.93 \\
(771,290.92)\end{array}$ & $\begin{array}{c}214,415.04 \\
(703,460.07)\end{array}$ \\
\hline
\end{tabular}

'Measured from top of monitor well casing. 


\subsection{DRILLING, CORNG, AND COMPLETION}

This section describes the drilling procedures used and data obtained; the collection of alluvial deposits, rock, and groundwater samples; and the installacion and stemming of monitoring well casing/screen and vadose zone instruments. Detailed procedures used to accomplish these activities are given in REECo Quality Assurance (QA) Standard Operating Procedures (SOPs) and Test Plans (TPs) listed in Table 2.1. In addition to following these formal procedures and recording data in procedure-specific forms, daily information on drilling, sampling, and completion activities were recorded in a log book.

\subsection{Drilling and Casing}

Each of the three Pilot Wells were drilled by Tonto Drilling Company with an Ingersol-Rand $\mathrm{T}-4 \mathrm{~W}$ rig using telescoping (successively smaller diameter) CAU drilling systems. Air was the only drilling fluid used. This drilling method has been described in detail by Hammermeister et al. (1986); therefore, only a brief description is included here. The method employed uses a downhole percussion hammer to drill and ream below the bottom joint of the casing. A pilot bit, in conjunction with an eccentric reamer, drills a hole slightly larger than the outside diameter (O.D.) of the casing. The percussion hammer forces the casing down the borehole by impacting on a shoe attached to the bottom joint of the casing. Thus, the casing is advanced downward as the borehole is drilled deeper. Drill cuttings are brought to the land surface through the casing, thereby minimizing the disturbance to the formation. The casing is moved downward until the desired depth for coring is reached. The interval is cored and then enlarged (reamed), and the casing is advanced to the bottom of the cored interval. This drilling, coring, reaming, and casing sequence is repeated until the total depth of the borehole is reached.

The CAU drilling system is ideally suited for vadose zone characterization studies because it minimizes the disturbance of properties related to in situ water content in the drill cuttings, core, and formation. It works well with air as a drilling fluid. The CAU drilling system cases (seals off) the formation from the drying effects of air immediately above the dill bit, and minimizes the exposure of drill cuttings to the air by moving them rapidly to the ground surface.

The drilling start and end dates, total depth, borehole diameters, and lithologies are summarized for all three Pilot Wells in Table 2.2. Related drilling information can also be found in the annual "Nevada Test Site Drilling and Mining Summary" compiled by Raytheon Services Nevada. Detailed chronological drilling summaries of each well, including problems and their resolution, are presented in Appendices A.1 to A.3.

Drilling penetration rates are presented in graphical form in Appendix A.4. Penetration rates are related to rock formation properties, drilling equipment condition and performance, and the particular techniques used by the drillers. The penetration rate graphs, together with the 
Table 2.1 Standard Operating Procedures (SOPs) and Test Plans (TPs) applicable to the Pilot Well Project.

\begin{tabular}{|c|c|c|c|}
\hline $\begin{array}{l}\text { Teat Plans } \\
\text { and Procedures }\end{array}$ & Title & Date & Rev. \\
\hline AND2D.T.01.00 & Surface Radiometric Survey Site Chanacterization Borchole & $08 / 21 / 91$ & 0 \\
\hline ADD2D.T.02.00 & Borehole Water Level Monitoring & $10 / 27 / 91$ & 0 \\
\hline AND2D.T.03.00 & Drawdown and Recovery Aquifer Teat Plan & $10 / 27 / 91$ & $\mathbf{0}$ \\
\hline AND2D.T.04.00 & Surface Resiativity Survey Site Charecterization Borehole & $10 / 17 / 91$ & 0 \\
\hline AMD2D.T.05.00 & Surface Magnetic Survey Site Characterization Borehole & $10 / 15 / 91$ & $\mathbf{0}$ \\
\hline AD2D.T.06.00 & Geologic Logging of Core and Drill Cuttings & $02 / 31 / 91$ & 0 \\
\hline AMD2D.T.07.00 & Measurement of Tritium Oxide in Soil Pore Gas & 08/31/91 & 0 \\
\hline AND2D.T.10.00 & Drilling, Coring, and Well Installation Project Plan & $12 / 10 / 91$ & $\mathbf{0}$ \\
\hline AAD2D.T.13.00 & $\begin{array}{l}\text { Determination of Mineralogic and Geologic Charecteriatics of Alluvial } \\
\text { Samples }\end{array}$ & $01 / 43 / 92$ & $\mathbf{0}$ \\
\hline WMD-T16 & $\begin{array}{l}\text { Science Trench Sampling for Determining Chamcterintics of Ceologic } \\
\text { Samples }\end{array}$ & $02 / 20 / 92$ & $\mathbf{0}$ \\
\hline WMD-T17 & Quality Asourance Project Plan for the Pilot Well Project & $04 / 24 / 92$ & 0 \\
\hline WMD-T18 & Pilot Well Geophysical Logging & $04 / 03 / 92$ & 0 \\
\hline WMD-T19 & $\begin{array}{l}\text { Pilot Well Core Sampling and Analysis for Hezardous and Radiological } \\
\text { Constituents }\end{array}$ & 05/01/92 & $\mathbf{0}$ \\
\hline WMD-T20 & Pilot Well Grounchwater Sampling and Aralysis & $05 / 12 / 92$ & $\mathbf{0}$ \\
\hline AND2D.D.04.00 & $\begin{array}{l}\text { Handling, Division, Preparation, Control, and Tranuport of } \\
\text { Characterization Samplea }\end{array}$ & 02/13/92 & $\mathbf{0}$ \\
\hline ADD2D.D.08.00 & Calibration of the Organic Vapor Monitor & $01 / 31 / 90$ & $\mathbf{0}$ \\
\hline WMD-D11 & Handling In-Progreas Datn Records for Special Projects Section Activities & $02 / 20 / 92$ & $\mathbf{0}$ \\
\hline WMD-D12 & Calculation Check Shed & $05 / 07 / 92$ & $\mathbf{0}$ \\
\hline WMD-D13 & $\begin{array}{l}\text { Use of Tracers to Determine Core and Groundwater Contamination from } \\
\text { Drilling }\end{array}$ & $05 / 18 / 92$ & $\mathbf{0}$ \\
\hline WMD-D15 & Gross Gamma Analysis of Pilor Well Core Samples & $04 / 03 / 92$ & 0 \\
\hline WMD-D17 & Pilot Well Abandorment & $05 / 18 / 92$ & $\mathbf{0}$ \\
\hline
\end{tabular}


Table 2.2 Summary of Pilot Well drilling and lithology information.

\begin{tabular}{|c|c|c|c|c|c|c|c|c|c|c|c|c|}
\hline \multirow{4}{*}{ Boreblole } & \multirow{4}{*}{$\begin{array}{l}\text { Surt } \\
\text { Dele }\end{array}$} & \multirow{4}{*}{$\begin{array}{l}\text { End } \\
\text { Dale }\end{array}$} & \multicolumn{8}{|c|}{ Boretrole Dimeter on (ia) } & \multirow{4}{*}{$\begin{array}{l}\text { Doreluole } \\
\text { Toul } \\
\text { Depit } \\
\text { (a) (a) }\end{array}$} & \multirow{3}{*}{ Lithelosy } \\
\hline & & & \multicolumn{2}{|c|}{$305.97(12.046)$} & \multicolumn{2}{|c|}{$237.31(9.343)$} & \multicolumn{2}{|c|}{$211.59(8.340)$} & \multicolumn{2}{|c|}{200.03 (1.075) } & & \\
\hline & & & from & 10 & froe & 10 & from & $\boldsymbol{\omega}$ & from & $\infty$ & & \\
\hline & & & \multicolumn{8}{|c|}{ Depth $=(\mathrm{a})$} & & \\
\hline UESPW-1 & 3-13-92 & $6-16-92$ & $\mathbf{0}$ & $\begin{array}{l}116 \\
(300)\end{array}$ & $\begin{array}{l}116 \\
(300)\end{array}$ & $\begin{array}{l}256 \\
(839)\end{array}$ & - & - & $\cdot$ & - & $\begin{array}{c}256 \\
(099.0)\end{array}$ & 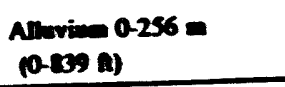 \\
\hline UESPW-2 & $6-18-92$ & $9-42$ & $\mathbf{0}$ & $\begin{array}{c}122 \\
(100)\end{array}$ & $\begin{array}{c}122 \\
(100)\end{array}$ & $\begin{array}{c}200 \\
(919.5)\end{array}$ & - & $\cdot$ & $\cdot$ & - & $\begin{array}{c}200 \\
(919.5)\end{array}$ & $\begin{array}{l}\text { Alming } 0.200= \\
\text { (0.919.5 a) }\end{array}$ \\
\hline UESTW-3 & $9-16-92$ & $11-9-92$ & $\mathbf{0}$ & $\begin{array}{l}137 \\
(450)\end{array}$ & $\begin{array}{l}137 \\
(450)\end{array}$ & $\begin{array}{l}235 \\
(770)\end{array}$ & $\begin{array}{l}235 \\
(\pi / v)\end{array}$ & $\stackrel{251}{(202.5)}$ & $\begin{array}{c}251 \\
(222.5)\end{array}$ & $\begin{array}{l}291 \\
\text { (955) }\end{array}$ & $\begin{array}{l}291 \\
\text { (95s.0) }\end{array}$ & 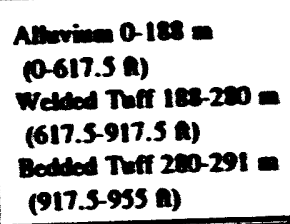 \\
\hline
\end{tabular}


drilling chronology summaries, show that numerous drilling problems were encountered and overcome in these holes. In almost all cases, these difficulties were related to the combined effects of a formation materials and the required use of air as the drilling fluid. The formation materials were primarily very dry, unconsolidated, and coarse-grained alluvium. The required use of air as the drilling fluid further destablized the already unstable borehole walls, resulting in "wash out" zones in some regions of hole. However, the borehole diameter depth profiles calculated from stemming material volumes (Section 2.5 ) show that extensive hole erosion was confined to relatively small intervals of the boreholes. Borehole geophysical density logs confirm that hole erosion was restricted to specific depth intervals (Section 4.3). Hole caving occurred in other depth intervals, creating a great deal of friction between the casing and formation and limiting the depth that a particular diameter CAU drilling system could be advanced. In summary, drilling activities never became routine, as different drilling problems were encountered in each borehole.

\subsection{Collection of Geologic Samples}

The CAU drilling system discussed above was in part selected because it produces drill cuttings samples that were remarkably representative of the formation. The system, when operated as designed, rapidly and nearly completely moves drill cuttings from the interval being drilled to the ground surface, ensuring that drill cuttings samples collected at the ground surface were in fact from the interval being drilled. Further, the rapid transport of drill cuttings to the ground surface minimizes the disturbance of the water content of the samples. Finally, the drilling action of the percussion hammer system minimizes the disturbance of the particle size distribution of unconsolidated alluvial materials penetrated. For these reasons, and because of the difficulty and high cost of coring unconsolidated alluvial materials, emphasis was placed on drill cuttings sample collection in this Projec:.

Certain important laboratory tests are not valid unless performed on samples with pore size distributions and water contents representative of the formation. Hence, coring unconsolidated alluvial materials, even though difficult and expensive, was necessary. The coring method described below is the only known method capable of producing this type of core sample from unconsolidated, relatively dry, coarse-grained alluvial deposits. Because this coring method is a standard industry method, it will only be briefly described in the Section 2.2.1.

Air-rotary coring was employed for coring the tuff formation underlying the alluvium in UESPW-3. This coring method was also unsuccessfully attempted in several of the more consolidated alluvium regions in UESPW-1 and UESPW-2. 


\subsubsection{Collection of Core Samples}

Core samples were collected from the alluvium at selected intervals (Tables 2.3, 2.4, and 2.5) using drive core methods. An air-percussion hammer was used to drive a 0.76-m (2.5-ft) long by $114.3-\mathrm{mm}$ (4.5-in) O.D. solid tube core barrel containing clear Lexan (polycarbonate) liner segments $(76.2-\mathrm{mm}$ [3-in] long by $88.9-\mathrm{mm}$ [3.5-in] O.D.) to contain the sample material. In several cases, a $1.5-\mathrm{m}(5.0-\mathrm{ft})$ long by $114.3-\mathrm{mm}$ O.D. core bartel was substituted for the $0.76-\mathrm{m}$ long barrel.

Past experience demonstrated that the drive core method provided good core recovery and minimized the disturbance of hydrologic conditions and physical properties of relatively dry coarse-grained unconsolidated alluvial samples (Hammermeister et al., 1986). Actual core recovery using these methods was generally excellent. Core loss or less-than-maximum recovery was mainly due either to blockage of the solid tube sample barrel with large rocks, or fallback of the cuttings (usually no more than $150 \mathrm{~mm}$ [6 in]) or loss of core from the core barrel while removing the core barrel from the borehole.

The process of drive coring unconsolidated alluvium could conceivably alter the pore size distribution of samples in several ways. Visual observation of core samples as they were removed from the core barrel indicated that the samples were generally very tightly packed into the liners. Visual inspection also showed fines accumulating along the outer edge of the core, suggesting some minor disturbance of the core along the outer circumference. This suggests that the drive coring process probably did not significantly decrease the compaction of the samples compared to in situ conditions. At the same time, it is hard to imagine that the coring process could significantly increase the compaction of relatively dry sandy alluvial materials which have in some cases been under as much as $275 \mathrm{~m}$ (900 ft) of overburden for many thousands of years. The possible effects of the coring process on the values of parameters that are sensitive to pore size distribution will be discussed further in Section 3.0.

Air-rotary core sampling methods were attempted in UESPW-1 and UESPW-2 in the more consolidated regions of alluvium (although still poorly consolidated) using HX core barrels (split inner tubes) with less success than drive core methods. In all cases, air-rotary core recovery was very poor in alluvial material. Air-rotary coring generally requires significant consolidation and/or cementation of the formation to yield reasonable recovery. Poor recovery in the two air-rotary core runs in welded tuff at UESPW-3 was probably due to a combination of factors, including the fractured nature of the formation and problems with stabilizing the core barrel and core rod within the relatively large diameter borehole. In all cases, the core barrels were transported to a temperature-controlled field laboratory for geologic description and disposition as soon as possible after removal from the borehole. 
Table 2.3 Core record for UESPW-1.

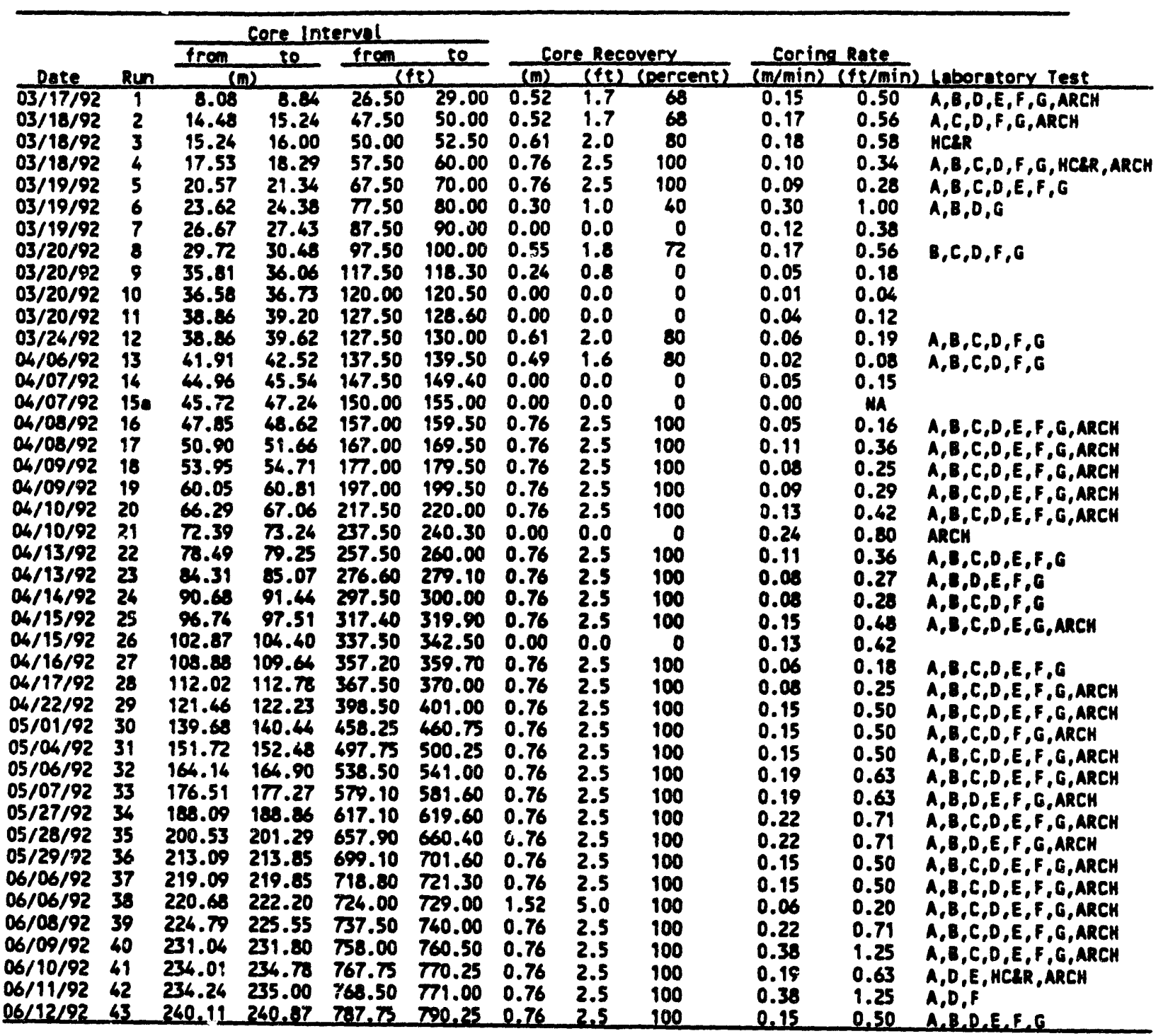

a: Rouny core

A: Physical and hydraulic properties

B: Particle size andysis, watar content

C: Chlorine. 36

D: Water potential, water content, bulk density

E: Clay mineralogy

F: Stable isotopes, tritium, bulk density, water consent

G: Chloride, bromide, sulfate, carbon, elemental mineralogy

HC\&R: Hazardous constituents and radionuclides

ARCH: Archived cemple 
Table 2.4 Core record for UESPW-2.

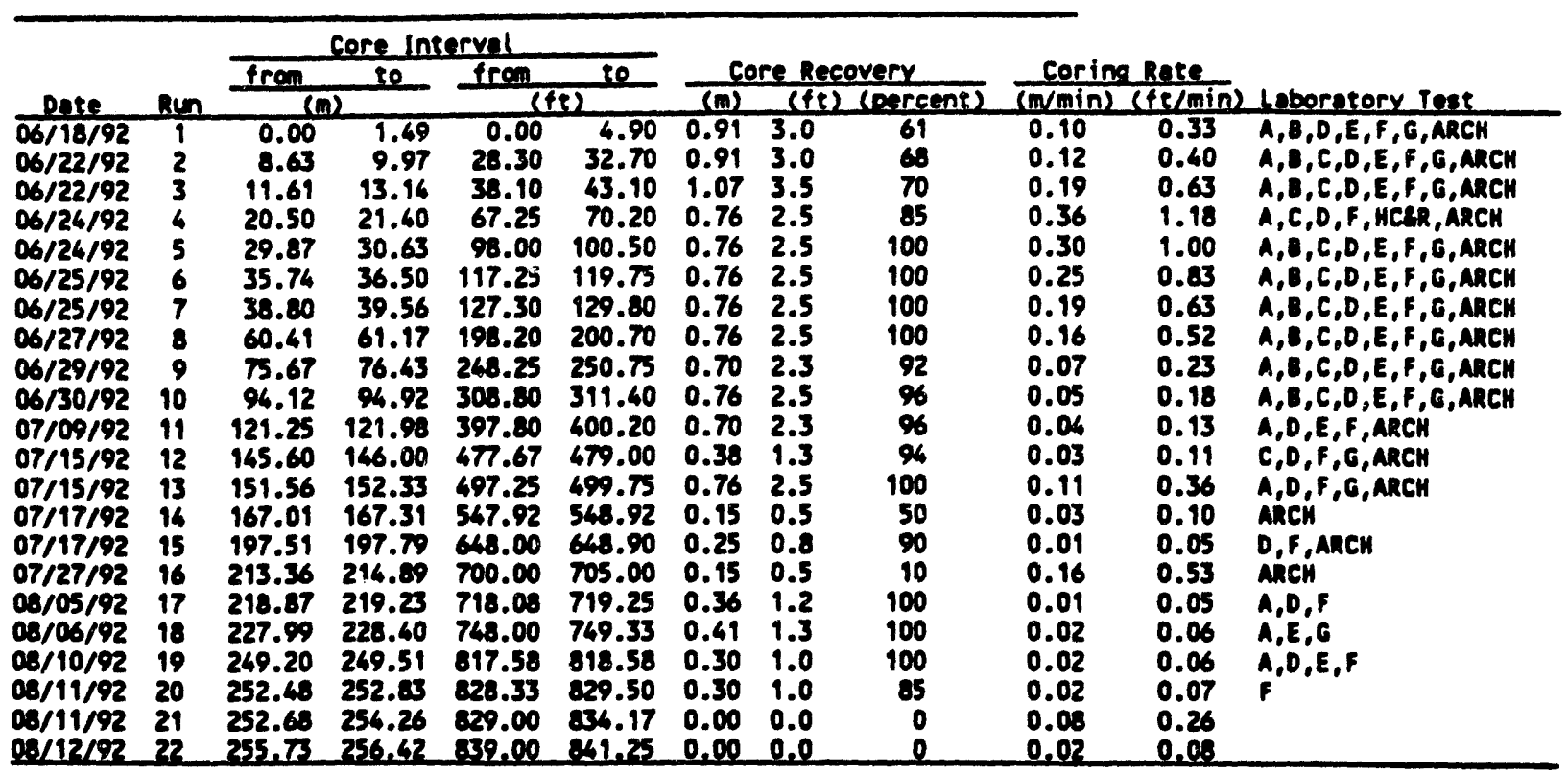

Table 2.5 Core record for UESPW-3.

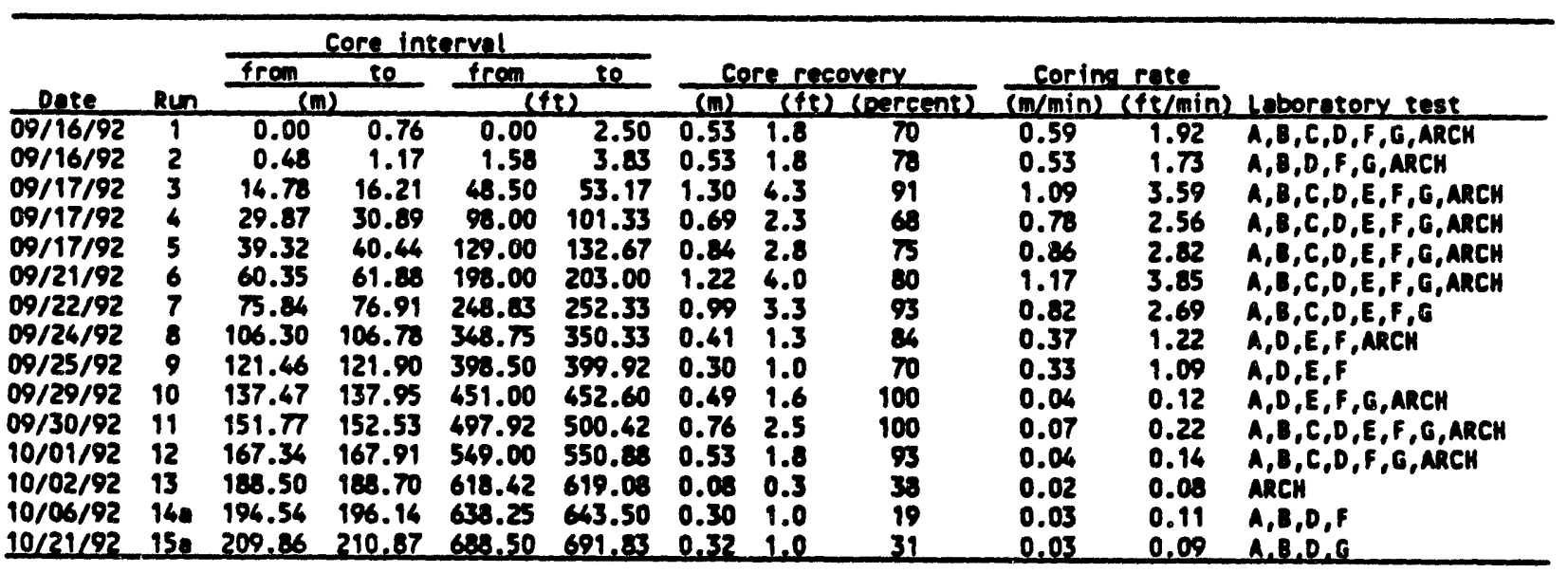

\section{a: Roury core}

A: Physical and hydraulic properties

B: Particle size asalysis, weter content

C: Chlorine-36

D: Water potential, water content, bulk density

E: Clay mineralozy

F: Stable isotopes, tritium, bulk density, whter content

G: Chloride, bromide, sulface, carbon, elemental mineralogy

HCQR: Hazardous conatituents and radionuclides

ARCH: Archived sample 


\subsubsection{Collection of Drill Cuttings Samples}

Drill cuttings samples were collected at $0.76-\mathrm{m}$ (2.5-ft) depth intervals from a cyclone separator. Drill cuttings samples were not collected during hole cleaning drilling activities. Sample collection procedures were designed to minimize the loss of water by evaporation. Immediately after drilling each $0.76-\mathrm{m}$ interval, a valve on the bottom of the cyclone separator was opened and a representative sample was collected in a bucket as drill cuttings fell into a large dumpster. A sample splitter was then used to obtain four subsamples from the bucket. These subsamples were placed in jars. The jars were capped, labeled with appropriate sample identification information, stored in plastic coolers, and taken to an temperature-controlled field laboratory as soon as logistically feasible.

\subsection{Geologic Description and Disposition of Samples}

Both drill cuttings and core samples were handled in the field laboratory and during subsequent storage and transport in a manner to minimize evaporative water loss, ensuring that the water content of samples was as close to in situ formation conditions as possible. Appropriate SOPs and TPs (Table 2.1) may be referred to for details on these procedures.

\subsubsection{Handling, Description, and Disposition of Core Samples}

Liner segments containing core samples were removed from the solid-tube drive core samplers by a pneumatic core extruder. A geologic description was then made on the core by examining the open ends of each 76.2- $\mathrm{mm}$ (3-in) long liner segment. This geologic description was recorded on field data forms which appear in Appendices B.1 to B.3. The description of the alluvium samples was based on methods from the American Society for Testing and Materials (ASTM), and the description of the tuff samples was based on procedures developed specifically for the NTS (Table 3.1).

Apparent magnetic susceptibility measurements were also made on both core and drill cuttings samples. Changes in magnetic susceptibility may be related to changes in lithology as well as other factors such as the rate of drill bit wear and the mixing of fine metal particles into the drill cuttings. These measurements were made on the flat ends of core segments and on the base of drill cuttings sample bottles using a Model KT-5 Exploranium meter. Measurements on samples should not be compared because of the different measurement conditions, including sample geometry, density, and type of container.

Following geologic description and measurement of magnetic susceptibility, each $76.2-\mathrm{mm}$ long core segment was capped, taped, and labeled with appropriate sample identification and intended use information. Core segments were further sealed in Protect-A-Core (a tubular laminate which, when sealed, protects the core from tampering and damage) and labelled again with the same information. Most of the core segments were specified for different 
types of laboratory testing, and the remainder were stored for future use. Tables 2.3, 2.4, and 2.5 summarize the uses specified for each core run. The intended use of each $76.2-\mathrm{mm}$ long core segment is summarized on detailed Borehole Log Sheets. Because core recovery was not always 100 percent, and further, because some core segments were more disturbed than others (e.g., disturbance of water content, porosity, and aggregation), the assignment of core segments for various tests was based on a priority system. This system took into account the relative importance of different laboratory tests, as well as the degree of sample disturbance acceptable for each test, and is described in detail in the applicable SOPs and TPs (Table 2.1). The core assignment procedure was altered when a core run contained a stratigraphic contact. In this case, cores on both sides of the stratigraphic contact were assigned to the same high-priority hydrologic parameter tests.

The labelling system used in the field to assign core segments and drill cuttings samples for different laboratory tests is summarized in Table 2.6. A particular sample label defined the laboratory testing required, the priority of these tests, and the laboratory responsible for conducting the analyses. In this report these labels are used to distinguish samples and responsible testing laboratories in tables of summary descriptive statistics of testing results and in figures of selected testing results in Section 3.0, and in tables of individual test results in Appendix $\mathbf{E}$.

\subsubsection{Handling, Description, and Disposition of Drill Cuttings Samples}

A geologic description of drill cuttings samples was made once samples were transported to the temperature-controlled field laboratory (Appendices B.4 to B.6). Sample jars containing drill cuttings were briefly opened, and the same geologic description and magnetic survey procedures referred to above for core samples were followed. Sample jars were then taped shut, sealed in Protect-A-Core, and labelled once again with appropriate sample identification information and intended use. Because these samples were more disturbed than core samples, fewer laboratory tests were specified. Four replicate drill cuttings samples were collected for these tests and other uses from each $0.76-\mathrm{m}$ (2.5-ft) depth interval. The labels assigned to drill cuttings samples which specified the tests to be conducted as well as the testing laboratories are summarized in Table 2.6.

\subsection{Field Tests on Core and Drill Cuttings}

\subsubsection{SF, Tracer Tests for Estimating Disturbance from Air Drilling Fluid}

Every effort was made to insure that air-percussion hammer-drive core samples were representative of in situ formation conditions. For example, drilling and air-percussion coring procedures in alluvium were designed and implemented so that drive core samples were collected from the bottom of the drillhole in formation materials where density, 
Table 2.6 Definitions of core and drill cuttings sample labels.

\begin{tabular}{|c|c|c|c|c|}
\hline $\begin{array}{l}\text { Sample } \\
\text { Type }\end{array}$ & $\begin{array}{l}\text { Sample } \\
\text { Label }\end{array}$ & $\begin{array}{l}\text { Sample } \\
\text { Priority }\end{array}$ & Laboratory Texting Specified & Testing Leboratory \\
\hline \multirow{8}{*}{ Core } & DBI & 1 & $\begin{array}{l}\text { Seturated hydraulic conductivity, moisture retention curves', } \\
\text { volumetric water content, dry bulk density, particle pize disuribution }\end{array}$ & Deniel B. Stephens \& Associmles, Albuquerque, NM \\
\hline & HYDI & 2 & $\begin{array}{l}\text { Gravimetric water content } \\
\text { Chloride, bromide, sulfece, inorganic carbon, organic carbon } \\
\text { Minerd element and oxide composition' }\end{array}$ & $\begin{array}{l}\text { Daniel B. Stephens \& Associstes, Albuquerque, NM } \\
\text { New Mexico Institute of Mining and Technology. } \\
\text { Dr. D. Branvold, Socorro, NM } \\
\text { New Mexico Institute of Mining and Technolozy. } \\
\text { Dr. P. Kyle, Socorro, NM }\end{array}$ \\
\hline & DRII & 3 & Suble isolopes of hydrogen and oxygen' & Desert Research Instiulue, Dr. S. Tyler, Reno, NV \\
\hline & DRI2 & 4 & Weter potential, volumetric water content, dry bulk density & Desert Recearch Institute, Dr. S. Tyler, Reno, NV \\
\hline & DB2 & 5 & Particle size disuribution, gravimetric water content & Daniel B. Stephens \& Associetes, Abuquerque, NM \\
\hline & HYD2 & 6 & Chlorine-36' & $\begin{array}{l}\text { Hydro CeoChem, Inc., Tucson, AZ and Lawrence Livermore } \\
\text { National Leboratory, Dr. M. Caffee, Livermore, CA }\end{array}$ \\
\hline & SNL & 7 & Clay mineralozy' & $\begin{array}{l}\text { Sandia National Leboretories, } \\
\text { Dr. H. Stockman, Abuquerque, NM }\end{array}$ \\
\hline & ARCH & 8 & To be determined & To Be Determined \\
\hline \multirow{4}{*}{$\begin{array}{l}\text { Drill } \\
\text { Cuntings }\end{array}$} & DB2 & 1 & Particle size distribution, gravimetric water content & Daniel B. Stephens \& Aseocintes, Albuquerque, NM \\
\hline & HYDI & 1 & $\begin{array}{l}\text { Gravimetric water content } \\
\text { Chloride, bromide, sulfute, inorganic carbon, organic carbon, }\end{array}$ & $\begin{array}{l}\text { Daniel B. Stephens \& Associales, Abuquerque, NM } \\
\text { New Mexico Institute of Mining and Technology. } \\
\text { Dr. D. Branvold, Socorro, NM }\end{array}$ \\
\hline & HYD2 & 1 & Chlorine-36 2 & $\begin{array}{l}\text { Hydro CeoChem, Ine., Tucson, AZ and Lawrence Livermore } \\
\text { Netiond Leboratory. Dr. M. Caffee, Livermore, CA }\end{array}$ \\
\hline & ARCH & 1 & To be determined & To Be Determined \\
\hline
\end{tabular}

- Tests conducted on selected samples

2 Chlorine-36 samples stored for future testing 
porosity, and pore size distribution had not been previously disturbed. However, the degree of drilling fluid (air) intrusion into the formation ahead of the drill bit, and consequently intocore samples collected from these formation materials, could not be accurately estimated prior to this drilling program. Even more difficult to estimate were the potentially disturbing effects of the drilling air on hydrologic conditions such as water content and water potential.

With this in mind, a program was implemented to estimate the extent to which the drilling fluid (air) penetrated into the formation (and core samples) directly ahead of the drill bit. A tracer gas (sulfur hexafluoride, $\mathbf{S F}_{6}$ ) was injected via a mass flow controller into the air stream originating from the air compressor during drilling and coring operations on UESPW-1. Failure of the mass flow controller prevented similar injections during drilling and coring in UESPW-2 and UESPW-3. However, SF 6 was injected into the uncased bottom portion of the UESPW-3 (235 to $291 \mathrm{~m}$ [770 to $955 \mathrm{ft}$ ) for $15 \mathrm{~min}$ during final reaming/cleaning of the borehole. This injection was accomplished by setting the $\mathrm{SF}_{6}$ tank pressure $689 \mathrm{kPa}\left(100 \mathrm{lb} / \mathrm{in}^{2}\right)$ above the compressor airstream pressure.

Concentrations of SF, were measured in air subsamples collected from the airstream, from the entire $0.76-\mathrm{m}$ (2.5-ft) long core barrel, and from $76.2-\mathrm{mm}$ (3-in) long individual core segments. The results of these analyses are presented in Appendix C.1. The results show that $\mathrm{SF}_{6}$ invaded all core samples to some extent, even segments located in the bottom of the core barrel which originated $0.76 \mathrm{~m}$ from the bottom of the original borehole. Large fluctuations in airstream line pressure resulted in large fluctuations in SF 6 concentrations in the airstream. This in turn prevented any quantitative analyses on the replacement of natural soil gases by air drilling fluid.

Analyses were conducted on extracted gases from 20.7- $\mathrm{mm}$ (0.814-in) inside diameter (I.D.) nylon access tubes leading to five instrument stations in UESPW-1 and one instrument station in UESPW-3. These analyses indicated that significant quantities of SF $_{6}$ were still in the formation adjacent to these stations several months after drilling and coring activities were completed (Appendix C.2). Prior to making any attempt to sample these instrument stations for in situ gases that could provide insight into pneumatic and hydraulic processes (e.g., ${ }^{14} \mathrm{CO}_{2}$ and fluorocarbons), access lines will be vacuum-pumped until concentrations return to less-than-detectable levels.

\subsubsection{Radiological Surveys of Geologic Samples}

Gamma radiation levels from drill cuttings were monitored continuously with an energycompensated Geiger-Mueller detector mounted directly on the cyclone separator. In addition, radiation protection workers analyzed drill cuttings samples and drilling and logging equipment via gamma spectroscopy and collected swipe samples for removable alpha and beta radiation contamination on a daily basis. Swipe samples were also collected from core barrels after each core run. All radiological monitoring results were consistent with natural levels of background radiation. 


\subsection{Pllot Well Completion}

This section briefly describes the materials, methods, and design followed to complete the three Pilot Wells. The completion involved installation and stemming of monitoring well casing/screen and vadose zone instruments in each well. Further details of all components of the completion design and operation are given in Appendix D.

The Pilot Well Completion objectives were:

- To install monitoring well casing/screen to provide access for sampling and hydraulic testing of the uppermost aquifer.

- To install pressure-, temperature-, and humidity-measuring instrumentation at selected intervals.

- To install air permeability test delivery tubing and remote pressure sensing/gas sampling tubing at selected intervals.

- To emplace annular sand pack to enhance filter pack/well screen effectiveness.

- To emplace permeable sand at instrument stations to enhance air movement between instrument stations and vadose zone formation.

- To emplace low-permeability annular seal materials between instrument stations to restrict preferential flow of fluids between instrument stations in the borehole annulus (short circuiting).

\subsubsection{Subsurface Completion Design}

The three Pilot Wells were completed according to the same basic design (Figures 2.1, 2.2, and 2.3). Each design includes a centralized approximately $63.5-\mathrm{mm}$ (2.5-in) 1.D. stainless steel casing. A 18.3-m (60-ft) long dual-screen prefabricated filter pack (Pre-Pack) was attached to the bottom of the central casing. Attached to the outside of the casing were a total of 34 instruments with associated cables and tubing running to 10 different depths in the borehole. Three major groups (stations) of instruments were located at the selected depths. Instrument stations and the associated instruments were as follows:

- Water level monitoring station consists of one submersible pressure transducer located

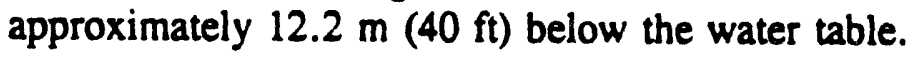

- Type A instrument stations consist of two thermistors for temperature measurements, two psychrometers for humidity measurements, and one air pressure transducer 


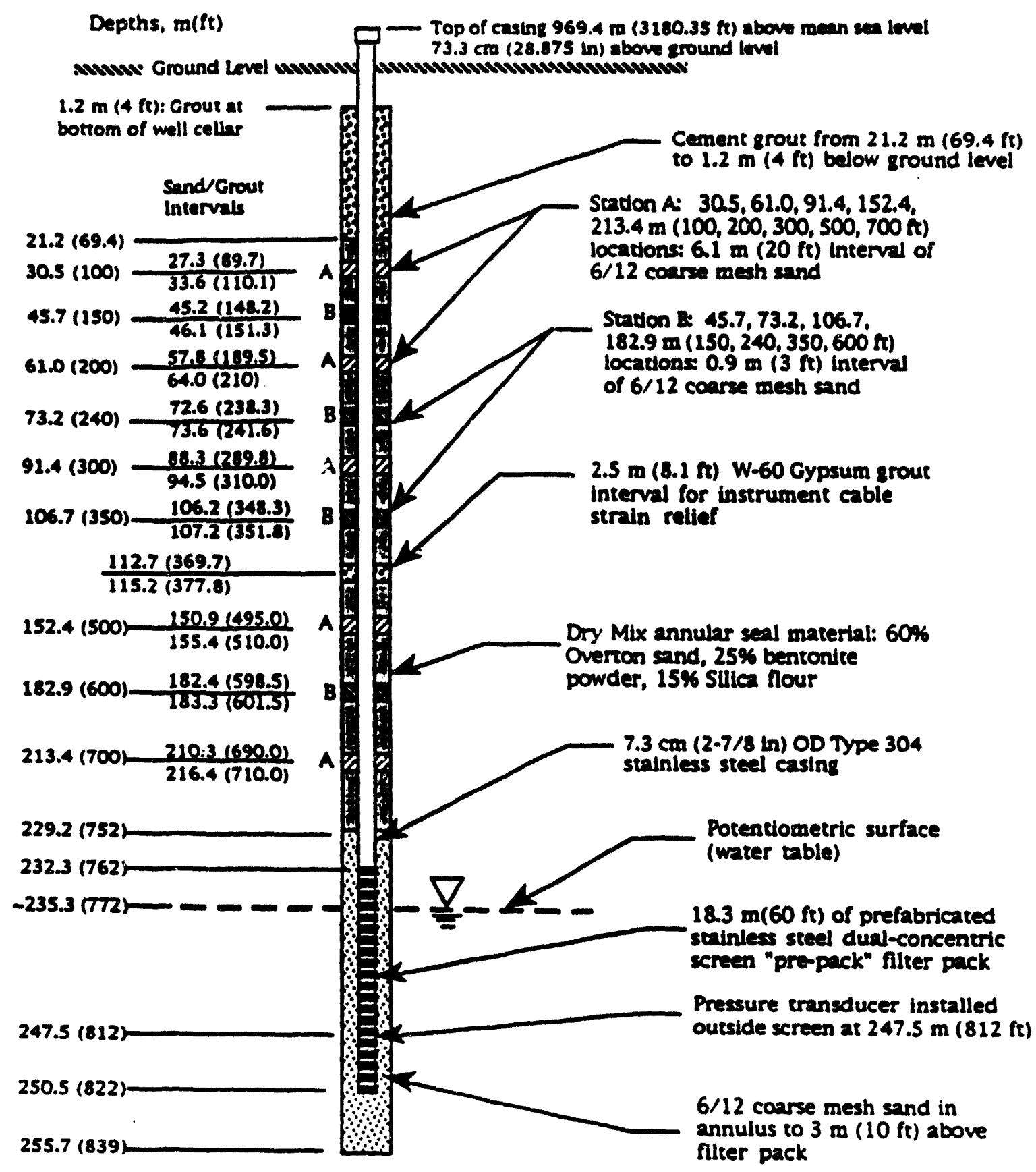

Figure 2.1 Completion detail for UESPW-1 


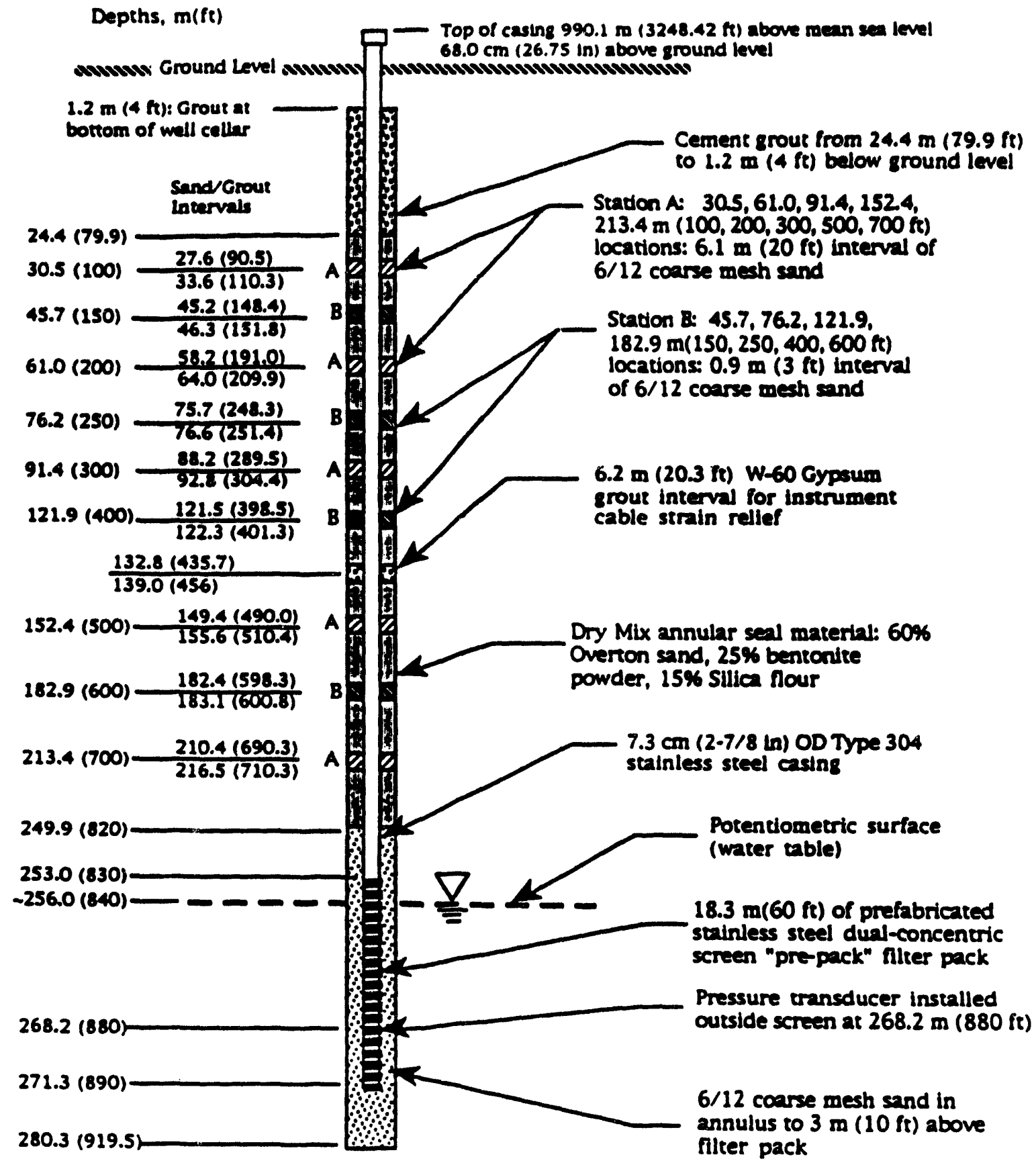

Figure 2.2 Completion detail for UESPW-2 


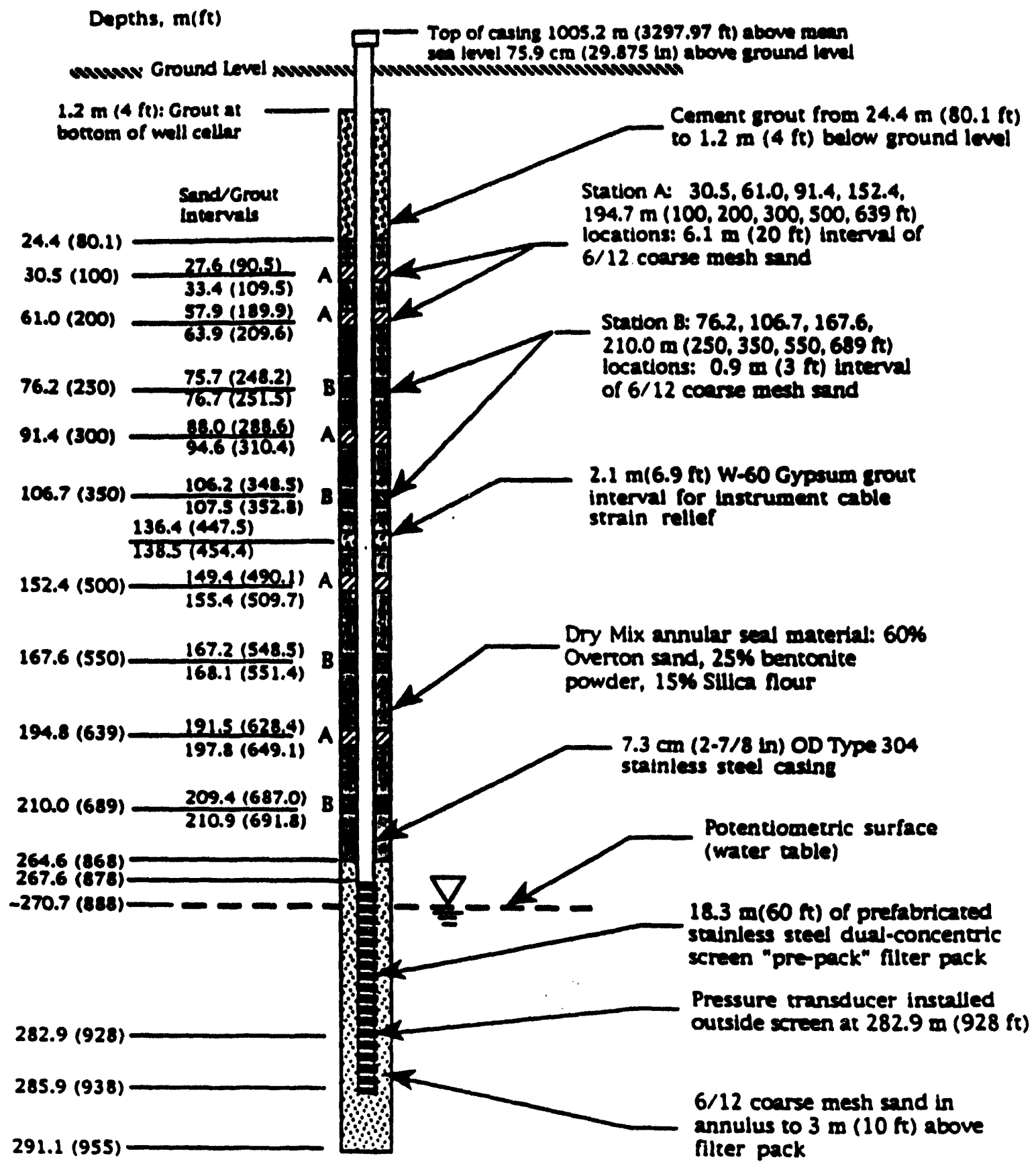

Figure 2.3 Completion detail for UESPW-3 
located at depths of approximately $30.5,61.0,91.4,152.4$, and $213.4 \mathrm{~m}(100,200,300$, 500 , and $700 \mathrm{ft}$ ).

- Type B instrument stations consist of screened air piezometers attached to $20.7-\mathrm{mm}$ (0.814-in) I.D. nylon tubing and 4.6-mm (0.18-in) I.D. stainless-steel tubing for air permeability testing and gas sampling located at depths of approximately 45.7, 76.2, 106.7 , and $182.9 \mathrm{~m}\left(150,250,35^{\prime}\right.$ nd $\left.600 \mathrm{ft}\right)$.

Note that some changes to the depths of several instrument stations were made to avoid "washed out" areas of the borehole or to correspond with core sample intervals. The actual depth of each instrument station is shown in the completion diagram for each Pilot Well.

The annular space around each station was stemmed with coarse-grained sand to facilitate pneumatic communication with the surrounding formation. The intervals between each station were stemmed with a low permeability bentonite/silica flour/sand mixture to eliminate preferential flow paths between the central casing and the formation. The air permeability of the dry low permeability mixture was found to be approximately $9.0 \times 10^{-14} \mathrm{~m}^{2}(90 \mathrm{mD})$ in laboratory tests. This value is at least two orders of magnitude less than the air permeability of the alluvial formation (Section 4.4.2).

\subsubsection{Subsurface Completion Operations}

After drilling was completed at each Pilot Well site, the drill rig was moved off the location, leaving the borehole with two strings of steel casing in place (219.1-mm [8.625-in] O.D. casing telescoped inside of 273.0-mm [10.75-in] O.D. casing). An Ingersoll-Rand TH-60 drill rig with a two-man crew was then moved on the borehole and used to complete each Pilot Well as described below. Details concerning materials used, preparation of the central casing and attachment of instruments, casing and instrument installation into the borehole, and stemming and cementing of the borehole are given in Appendix D.

The completion drill rig was used to run the centralized monitoring well casing/screen with attached instruments and associated cables and tubes inside the inner $219.1-\mathrm{mm}$ casing to the required depth. The completion rig was then used to pull (with hydraulic jacks) the inner drill casing from the borehole in $3.0-\mathrm{m}$ or $6.1-\mathrm{m}$ (10-ft or 20-ft) stages As this casing was pulled out of the borehole, dry stemming materials were added to fill the annular space between the formation and the centralized casing and attached instruments. The low permeability mixture was pumped down a steel tremmie pipe (1-in Schedule 80) to the depth interval of interest with a Shotcrete injector. The coarse-grained sand was simply poured into the tremmie and allowed to fall by gravity to the interval being stemmed. Frequent measurements of the level of stemming materials in the borehole demonstrated that these materials did not settle downward during the stemming operation. To minimize future settling and provide strain relief for instrument cables and tubes, a gypsum grout interval was placed midway in the borehole. 
When the 219.1-mm inner casing was pulled up to the depth of the $273.0-\mathrm{mm}$ casing, the former casing was pulled completely from the hole. The $273.0-\mathrm{mm}$ casing was then pulled up in stages and stemming materials added a- Jescribed previously for the 219.1-mm casing. When the $273.0-\mathrm{mm}$ casing was pulled up to approximately $24.4 \mathrm{~m}$ ( $80 \mathrm{ft}$ ) below ground surface, cement grout was poured into the casing. The casing was then pulled completely out of the hole, while adding grout as required, leaving a cement surface seal from a depth of approximately $24.4 \mathrm{~m}$ to the ground surface.

\subsubsection{Surface Facilities and Wellhead Completion}

Figure 2.4 shows the surface facilities constructed at each Pilot Well site. There are two buildings situated at each location: a wellhead building (which, in conjunction with a $3 \mathrm{~m}$ by $3 \mathrm{~m}$ [10 ft by $10 \mathrm{ft}$ ] concrete pad, provides weather protection, surface seal, and lockable access to the well in accordance with RCRA requirements); and an instrument building (housing the data acquisition system and related equipment).

The wellhead building consists of $a 2.4 \mathrm{~m}$ by $6.1 \mathrm{~m}$ ( $8 \mathrm{ft}$ by $20 \mathrm{f}$ ) transportainer and is located over the casing. This building houses the Bennett sample pump and other equipment and tools needed for groundwater sampling. A steel floorplate with a $0.6 \mathrm{~m}$ by $0.6 \mathrm{~m}(2 \mathrm{ft}$ by $2 \mathrm{ft}$ ) trapdoor provides access to the $1.8 \mathrm{~m}(6 \mathrm{ft})$ diameter by $1.2 \mathrm{~m}(4 \mathrm{ft})$ deep well cellar. Cables from downhole instruments were routed through a $152.4-\mathrm{mm}$ (6-in) diameter electrical conduit from the well cellar to the instrument building.

The instrument building was kept separate from the wellhead building in order to protect the electronics from vibrations or mechanical shock from pumping or other well activity. It contains an environmental chamber, that protects the data acquisition system.

\subsection{Well Development}

The three Pilot Wells were developed to help insure that hydraulic and other testing conducted in these wells will yield results that are as representative as possible of the uppermost aquifer, and are not indicative of disturbed conditions caused by drilling and coring activities. The small diameter of the monitoring well casing (63.5-mm [2.5-in] 1.D.) and screen (60.3-mm [2.375-in] I.D.) combined with the great depth to the water table (greater than $235 \mathrm{~m}$ [770 ft]) restricted the choice of development methods to bailing and low flow-rate pumping.

Initial development was conducted by bailing with an approximately 38.1-mm (1.5-in) O.D. by $6.1-\mathrm{m}(20-\mathrm{ft})$ long polyvinyl chloride bailer attached to a wireline system. During each bailing episode the bailer was run up and down between the water table surface and the bottom of the well screen several times before removing the bailer from the well. The 


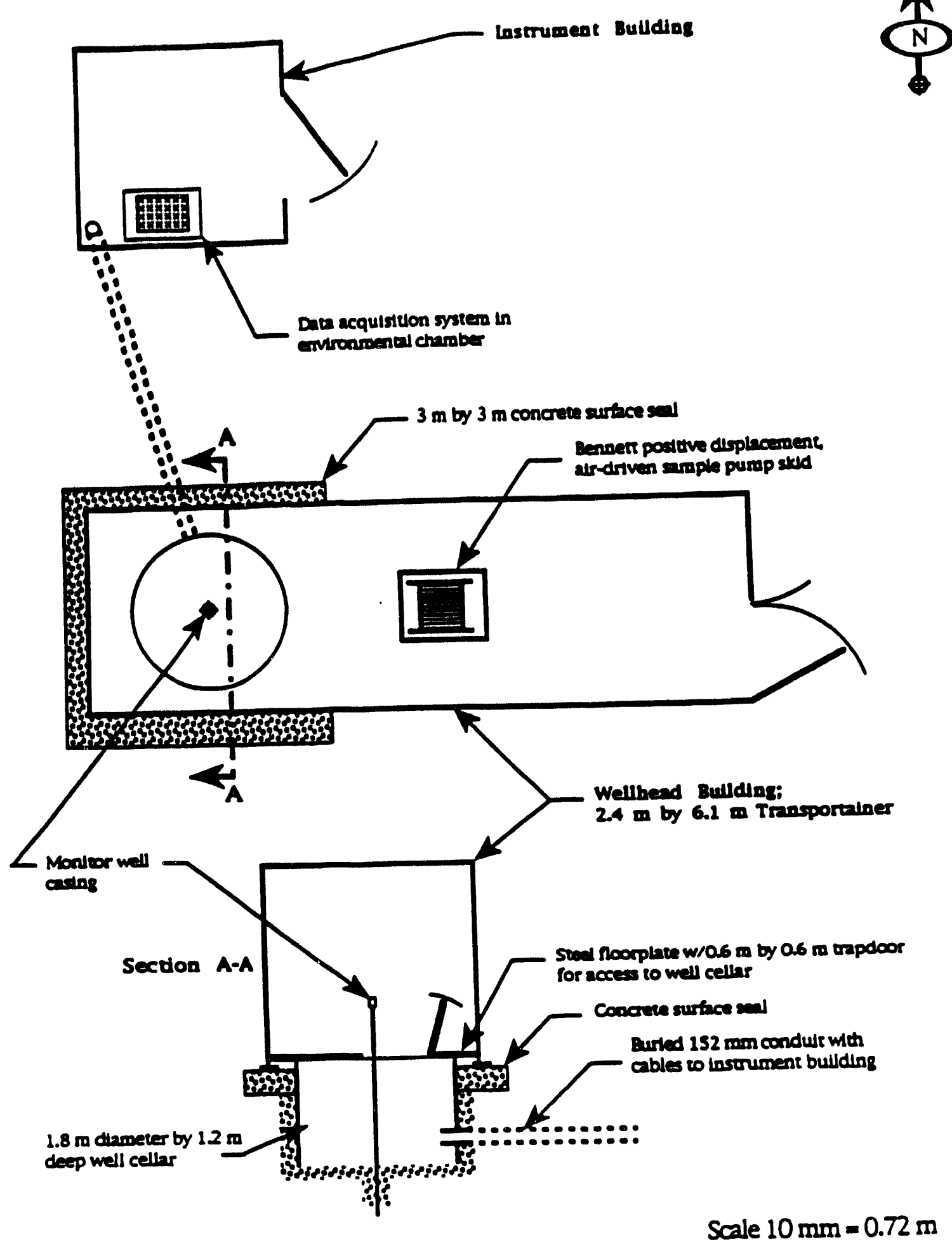

Figure 24 Surface facilities and wellhead completion 
turbidity of the bailed water decreased significantly with bailing. However, in all three wells the water never cleared completely. Bailing was discontinued when it appeared that this activity began to have little or no noticeable effect on decreasing turbidity.

Further development with a low flow-rate sample pump (Bennett pump) was not started until at least several days after bailing was completed to allow suspended sediment to settle to the bottom of the well screen. The sample pump was then lowered into the well screen to a predetermined depth and the well was pumped at the maximum sample rate (approximately $2 \mathrm{~L} / \mathrm{min}[0.5 \mathrm{gal} / \mathrm{min}]$ ). In all cases the pump was positioned at least $6.1 \mathrm{~m}$ above the bottom of the well screen to prevent disturbing any sediment which had settled to the bottom of the screen. The outlet line of the pump was connected to a flow-through cell and the general water quality parameters of $\mathrm{pH}$, temperature, conductivity, and Eh of the pumped water were monitored together with flow-rate. Pumping generally continued at a particular depth until at least three wellbore volumes of water were removed and the general water quality parameters stabilized. If the schedule for development and sampling permitted, the above described development procedure was repeated at several $1.5-\mathrm{m}(5-\mathrm{ft})$ intervals. The volumes of water bailed and pumped as well as final values of water quality parameters for each development episode are summarized in Table 2.7. 
Table 2.7 Pilot Well development data.

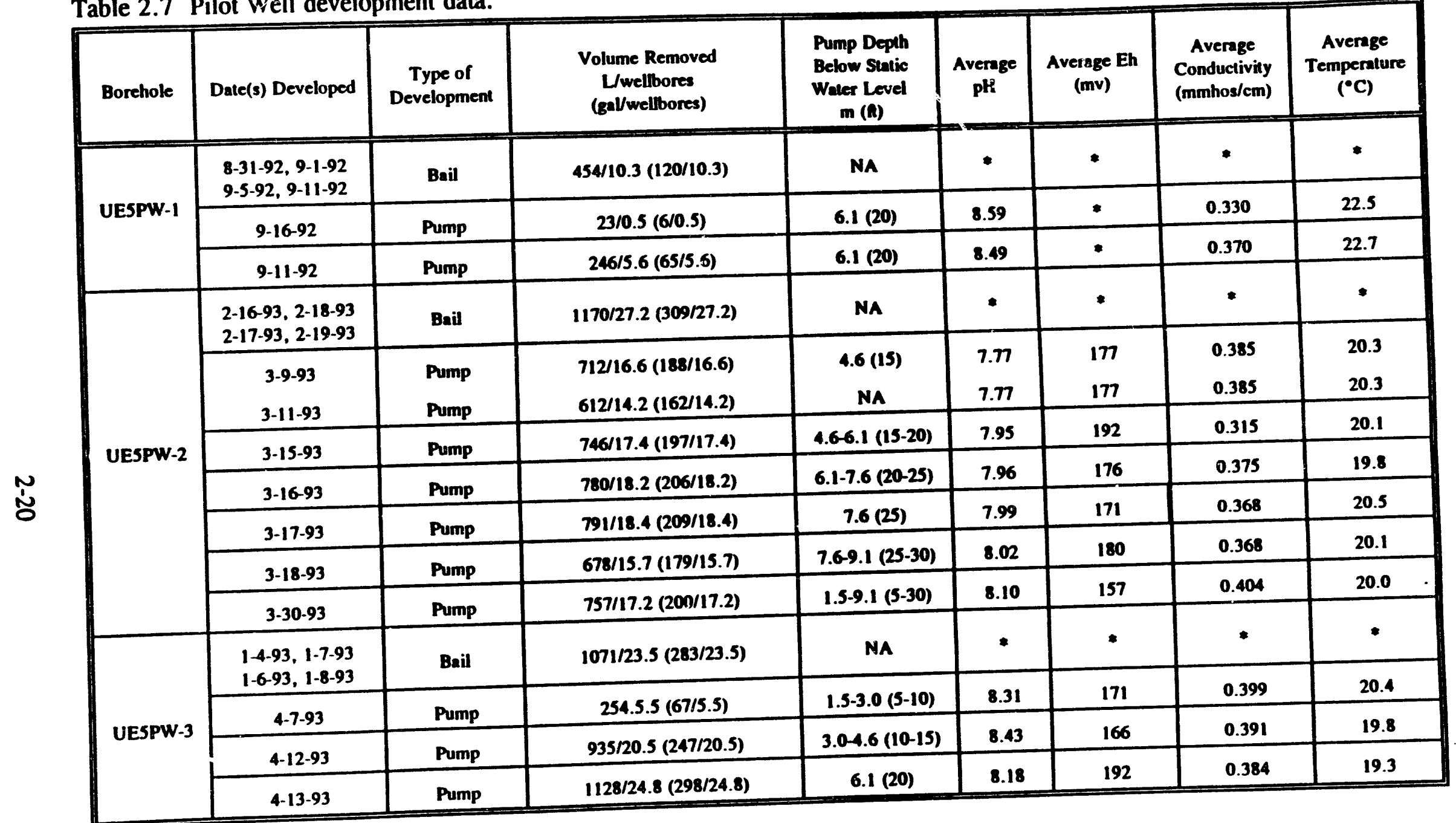

- Parameter nol measured 


\subsection{LABORATORY TESTING METHODS AND RESULTS}

A summary of laboratory tests and testing methods is given in Table 3.1 and specific details are contained in the cited references. In addition, a description of all laboratory testing methods used in the Pilot Well Project is given in the Science Trench Borehole data report (REECo, 1993a).

As described in Section 2.3 and Table 2.6, drill cuttings and core samples were sent to selected testing laboratories to measure material, hydrologic, mineralogic, and geochemical properties. In most cases, a testing laboratory conducted a number of related tests on the same core segment. For example, initial water content, bulk density, porosity, hydraulic conductivity, moisture retention, and particle size distribution measurements were conducted on the same core segment. A number of samples have been placed in storage (archived) for future testing as required.

REECo has audited and approved the QA programs of the following laboratories involved in the Pilot Well Project. Daniel B. Stephens \& Associates, Inc. (DBS\&A), Albuquerque, New Mexico was responsible for review and approval of the QA programs for the laboratories of Dr. B. Branvold and Dr. P. Kyle, New Mexico Institute of Mining and Technology (NMMMT), Socorro, New Mexico. REECo reviewed and approved the QA program of Hydro GeoChem (HGC), Inc., Tucson, Arizona. Sandia National Laboratories (SNL), Albuquerque, New Mexico, was responsible for review and approval of the QA programs for the laboratories of Dr. S. Tyler, Desert Research Institute (DRI), Reno, Nevada and Dr. M. Caffee, Lawrence Livermore National Laboratory (LLNL), Livermore, California.

The types and numbers of tests conducted on core and drill cuttings samples for each Pilot Well are summarized in Table 3.2. The tabular results from these laboratory tests for both core and drill cuttings samples are summarized in Appendix E. Summary statistics for laboratory measurements, where appropriate, are presented in Table 3.3 for samples from the alluvium and in Table 3.4 for samples from the tuff. Plots of laboratory testing results for specific tests are presented in the appropriate sections which follow.

\subsection{General Geologic Description, Lithology, Stratigraphy, Mineralogy and Organic Matter}

General geologic descriptive information, as well as specific lithologic and stratigraphic information, are useful in identifying the overall geometry of the hydrogeologic flow system, layers with possibly distinctive physical and hydrogeologic properties, and potentially important flow paths. This information is necessary to understand and model important processes under the existing arid climate, as well as for possible future climatic scenarios. 
Table 3.1 Summary of laboratory methods.

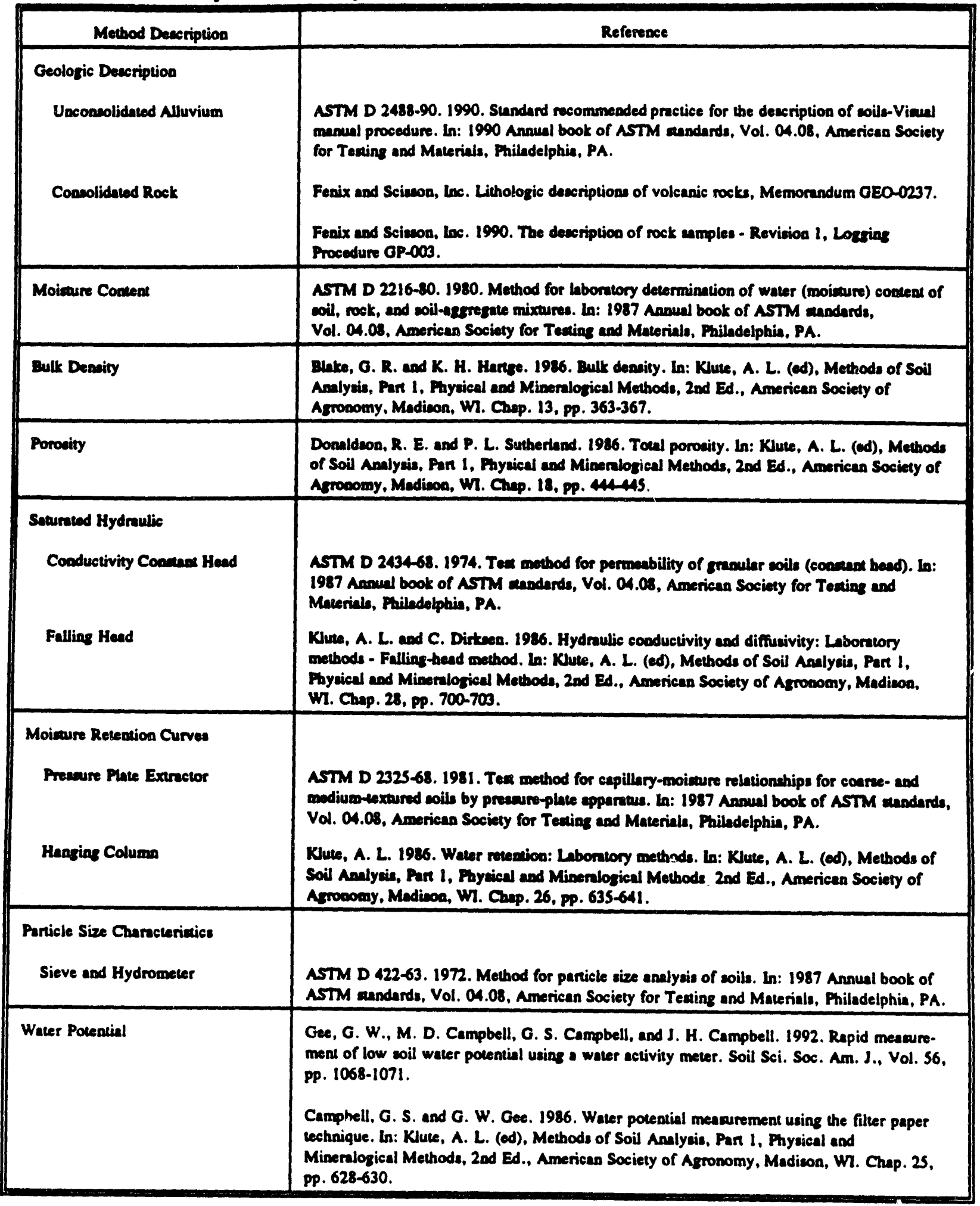


Table 3.1 Summary of laboratory methods (Continued).

\begin{tabular}{|c|c|}
\hline Mechod Doseription & Reforence \\
\hline \multicolumn{2}{|l|}{ Chloride and Bromide } \\
\hline Extretion from Soil & $\begin{array}{l}\text { Los Namos National Laborntory. 1992. Sample lasehing to extraet soluble chloride and } \\
\text { bromide. LANL-NC-DP-92.R0.pp. 3-15. }\end{array}$ \\
\hline Ion Chromatogrnphy Amalysis & $\begin{array}{l}\text { Los Namos National Labortory. 1991. Dren. Procedure for uning ion chromatography to } \\
\text { detormise chloride and bromide concentrations. LANL-DNC-DP-94.RO, pp. 3-25. }\end{array}$ \\
\hline Toul Organic Carbon & 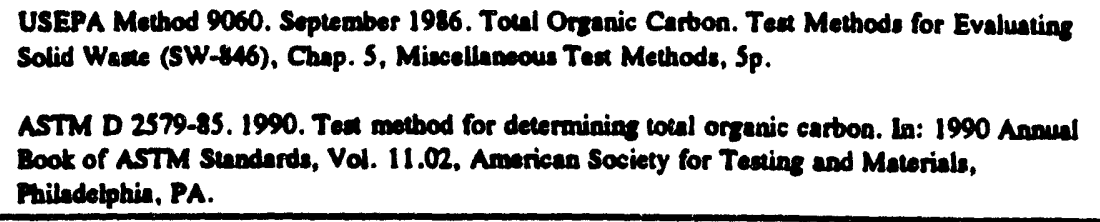 \\
\hline Inorganic Carbon & 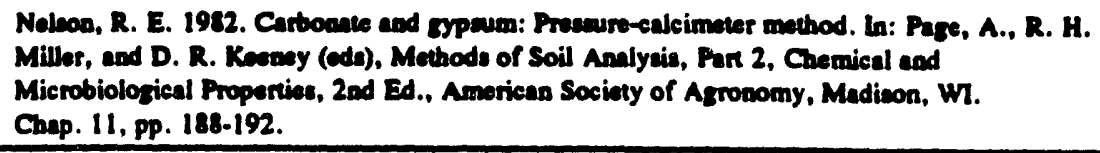 \\
\hline \multicolumn{2}{|l|}{ Culorien-36 } \\
\hline Exinction from soil & 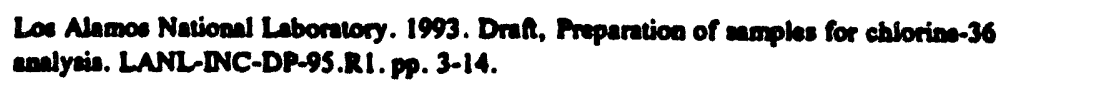 \\
\hline Mase Spectroscopy Amalyais & 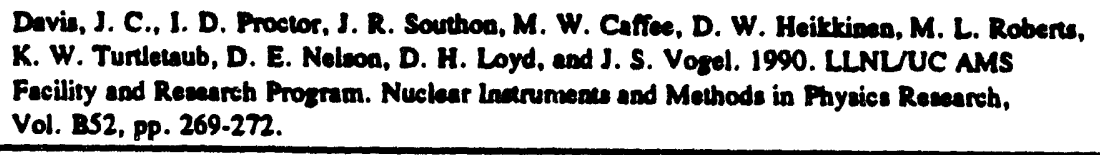 \\
\hline \multicolumn{2}{|l|}{ Stuble Lotopes } \\
\hline Tolvene Enunction & 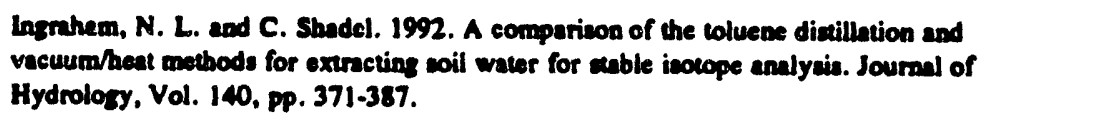 \\
\hline Mass Spectroscopy Amalyzis & Not obruised at time of writing this repon. \\
\hline Water Soluble und Adeorbed Sulfate & $\begin{array}{l}\text { Tabarabai, M. A. 1982. Sulfur: inorganic mulfate. In: Page, A. L., R. H. Miller, and D. R. } \\
\text { Keanay (eds), Meathods of Soil Analycis, Pan 2, Chemical asd Microbiclogical Properties, } \\
\text { 2ad Ed., Amarican Society of Agronomy, Madison. W. Chap. 28, pp. S18-522. }\end{array}$ \\
\hline $\begin{array}{l}\text { Semple Proparation and Amalyais by } \\
\text { X-Rey Fluoreacesce (XRF) }\end{array}$ & 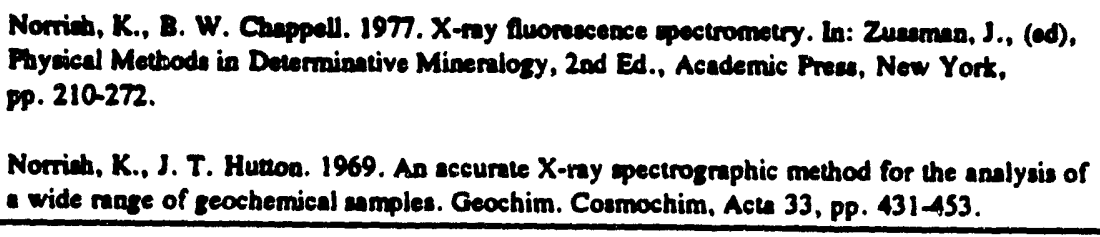 \\
\hline $\begin{array}{l}\text { Sample Preparntion and lnatrumental } \\
\text { Neutron Activation Analysis (WNAA) }\end{array}$ & $\begin{array}{l}\text { Jacobs, J. W., R. L. Konolev, D. P. Blanchard, and L. A. Haskins. 1977. A well-terted } \\
\text { procedure for inanumental neutron activation analysis of silicate rocks and minerals. J. } \\
\text { Radionnal. Chem. 40, pp. 93-114. }\end{array}$ \\
\hline
\end{tabular}


Table 3.2 Summary of tests performed on samples from the Pilot Wells.

\begin{tabular}{|c|c|c|c|c|c|c|c|c|c|c|c|c|c|c|c|}
\hline \multicolumn{2}{|c|}{ Borebole } & \multicolumn{2}{|c|}{ UESPW-1 } & \multicolumn{2}{|c|}{ UESPW-2 } & \multicolumn{3}{|c|}{ UWSPW-3 } & & \multicolumn{2}{|c|}{ UESPW-2A } & \multicolumn{2}{|c|}{ UESPW-2B } & \multicolumn{2}{|c|}{ UESPW-2C } \\
\hline \multirow{4}{*}{$\begin{array}{l}\text { Semple } \\
\text { type }\end{array}$} & Alluvium & $x$ & $x$ & $x$ & $x$ & $x$ & $\mathbf{x}$ & & & $x$ & $x$ & $x$ & $x$ & $x$ & $x$ \\
\hline & Tuti & & & & & & & $x$ & $x$ & & & & & & \\
\hline & Core & $x$ & & $x$ & & $x$ & & $x$ & & $x$ & & $x$ & & $x$ & \\
\hline & Curriags & & $x$ & & $x$ & & $x$ & & $x$ & & $x$ & & $x$ & & $x$ \\
\hline \multirow{6}{*}{$\begin{array}{l}\text { Hydrologic } \\
\text { propenice }\end{array}$} & $\begin{array}{l}\text { Hydraulic } \\
\text { conductivity }\end{array}$ & 34 & - & 16 & - & 10 & - & 3 & - & - & - & - & - & - & - \\
\hline & $\begin{array}{c}\text { Air } \\
\text { permobility }\end{array}$ & - & . & - & - & - & - & 3 & - & - & - & - & - & - & . \\
\hline & $\begin{array}{l}\text { Moimare } \\
\text { recention }\end{array}$ & 24 & - & 16 & - & 9 & - & - & - & - & - & - & - & - & . \\
\hline & $\begin{array}{l}\text { Onvibetric } \\
\text { wher comtent }\end{array}$ & 146 & 595 & 58 & 706 & so & 48 & $s$ & 79 & 15 & 26 & 5 & 15 & 12 & 30 \\
\hline & $\begin{array}{l}\text { Voluncerric } \\
\text { weer comene }\end{array}$ & 76 & - & 34 & - & 23 & • & 3 & $\cdot$ & 14 & - & 5 & - & 12 & - \\
\hline & Worer & S) & - & 25 & - & 18 & - & 2 & 19 & 4 & - & 1 & - & 3 & - \\
\hline \multirow{7}{*}{$\begin{array}{l}\text { Mecerial } \\
\text { propertiea }\end{array}$} & Hydrometer & 3 & 11 & 15 & 96 & 12 & - & - & - & 3 & . & 1 & . & 1 & - \\
\hline & Dry sieve & 56 & 299 & 20 & 355 & 25 & 24 & - & - & 7 & 13 & 2 & 8 & 5 & 15 \\
\hline & $\begin{array}{l}\text { Bulk } \\
\text { denity }\end{array}$ & 76 & - & 34 & - & 23 & - & 3 & - & 14 & - & 5 & - & 12 & - \\
\hline & $\begin{array}{c}\text { Orais } \\
\text { deasity }\end{array}$ & • & - & $\cdot$ & $\cdot$ & $\cdot$ & $\cdot$ & 3 & $\cdot$ & - & - & - & - & • & - \\
\hline & $\begin{array}{l}\text { Culculeced } \\
\text { poroaity }\end{array}$ & 76 & $\cdot$ & 34 & - & 23 & $\cdot$ & 3 & - & 14 & - & 5 & - & 12 & . \\
\hline & $\begin{array}{l}\text { Seturated } \\
\text { porvaity }\end{array}$ & 24 & $\cdot$ & 16 & - & 9 & $\cdot$ & - & - & - & - & - & - & - & . \\
\hline & Misernlozy & 34 & - & 13 & - & 13 & - & 3 & - & 4 & - & 2 & - & 4 & . \\
\hline \multirow{6}{*}{$\begin{array}{l}\text { Enviros- } \\
\text { meath } \\
\text { tracen }\end{array}$} & Carbos & 38 & 288 & 13 & 355 & 12 & 246 & 2 & 134 & - & 13 & - & 7 & - & 15 \\
\hline & Chloride & 38 & 287 & 14 & 353 & 12 & 246 & - & 134 & 4 & 13 & 2 & 7 & 4 & is \\
\hline & Bromide & 26. & 234 & 14 & 324 & 12 & 246 & - & 129 & 4 & 13 & 2 & 7 & 4 & 15 \\
\hline & Sulfate & 1 & 15 & 14 & 353 & 12 & 246 & - & 134 & 4 & 13 & 2 & 7 & 4 & 15 \\
\hline & Chlorise-36 & 9 & - & - & - & - & - & - & - & - & - & - & - & - & . \\
\hline & $\begin{array}{l}\text { Suble } \\
\text { iscropes }\end{array}$ & 22 & - & 16 & - & 14 & - & 1 & - & • & . & . & - & - & - \\
\hline
\end{tabular}


Table 3.3 Summary of descriptive statistics of alluvium samples from the Pilot Wells.

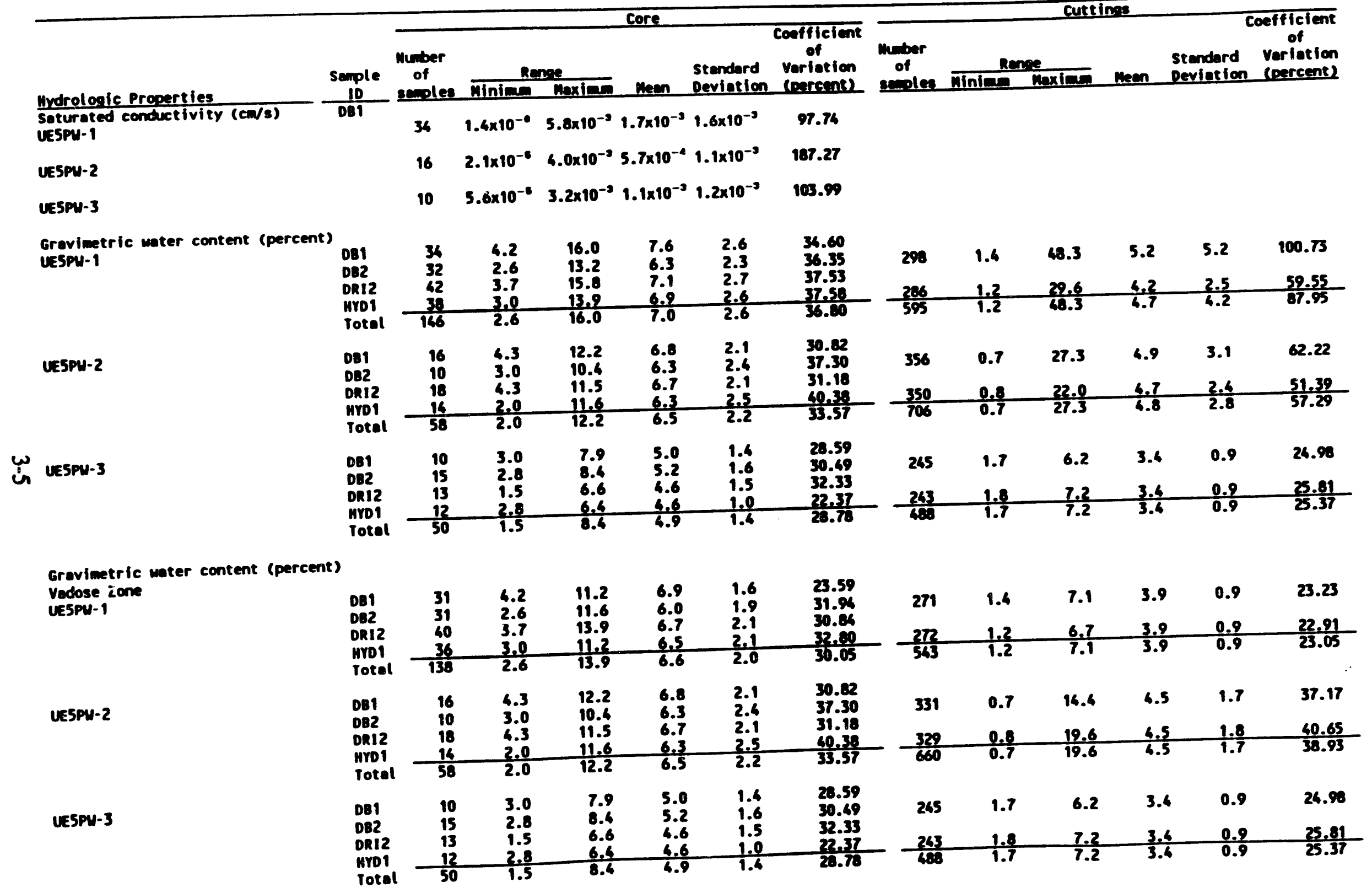


Table 3.3 Summary of descriptive statistics of alluvium samples from the Pilot Wells (continued).

\begin{tabular}{|c|c|c|c|c|c|c|c|}
\hline \multirow{3}{*}{ Uydrologic Properties } & \multirow{3}{*}{$\begin{array}{c}\text { Sample } \\
10\end{array}$} & \multicolumn{6}{|c|}{ Core } \\
\hline & & $\begin{array}{l}\text { Numer } \\
\text { of }\end{array}$ & Rer & & & stendard & $\begin{array}{l}\text { Coefficient } \\
\text { of } \\
\text { veriation }\end{array}$ \\
\hline & & semples & Minimen & Meximen & Meen & Devintion & (Darcent) \\
\hline 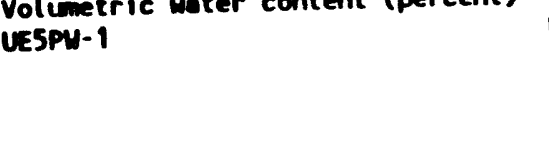 & $\begin{array}{l}\text { D81 } \\
\text { DR12 } \\
\text { Total }\end{array}$ & $\begin{array}{l}34 \\
42 \\
76\end{array}$ & $\begin{array}{l}6.5 \\
5.6 \\
5.6\end{array}$ & $\begin{array}{l}26.8 \\
28.6 \\
28.6\end{array}$ & $\begin{array}{l}12.4 \\
11.7 \\
12.0\end{array}$ & $\begin{array}{r}6.6 \\
4.9 \\
6.7\end{array}$ & $\begin{array}{l}36.93 \\
61.53 \\
39.27\end{array}$ \\
\hline UE5PU-2 & $\begin{array}{l}\text { DB1 } \\
\text { DR12 } \\
\text { Total }\end{array}$ & $\begin{array}{l}16 \\
18 \\
36\end{array}$ & $\begin{array}{l}7.5 \\
7.3 \\
7.3\end{array}$ & $\begin{array}{l}21.0 \\
15.9 \\
21.0\end{array}$ & $\begin{array}{l}11.2 \\
10.6 \\
10.9\end{array}$ & $\begin{array}{l}3.5 \\
2.5 \\
3.0\end{array}$ & $\begin{array}{l}31.45 \\
23.35 \\
27.37\end{array}$ \\
\hline UESPU-3 & $\begin{array}{l}\text { DB1 } \\
\text { DR12 } \\
\text { Total }\end{array}$ & $\begin{array}{l}10 \\
13 \\
23\end{array}$ & $\begin{array}{l}4.9 \\
\frac{2.6}{2.6}\end{array}$ & $\begin{array}{l}13.2 \\
10.7 \\
13.2\end{array}$ & $\begin{array}{l}8.4 \\
7.5 \\
7.9\end{array}$ & $\begin{array}{l}2.5 \\
2.3 \\
2.3\end{array}$ & $\begin{array}{l}29.06 \\
30.37 \\
29.73\end{array}$ \\
\hline $\begin{array}{l}\text { Volumetric water content (percent) } \\
\text { Vadose Zone }\end{array}$ & & & & & & & \\
\hline UESPU-1 & $\begin{array}{l}\text { D8! } \\
\text { DR12 } \\
\text { Total }\end{array}$ & $\begin{array}{l}31 \\
40 \\
71\end{array}$ & $\begin{array}{l}6.5 \\
5.6 \\
5.6\end{array}$ & $\begin{array}{l}16.6 \\
23.0 \\
23.0\end{array}$ & $\begin{array}{l}11.2 \\
11.0 \\
11.1\end{array}$ & $\begin{array}{l}2.5 \\
3.6 \\
3.2\end{array}$ & $\begin{array}{r}22.41 \\
33.17 \\
23.69\end{array}$ \\
\hline UESPU-2 & $\begin{array}{l}\text { DB1 } \\
\text { DRI2 } \\
\text { Total }\end{array}$ & $\begin{array}{l}16 \\
18 \\
34\end{array}$ & $\begin{array}{l}7.5 \\
7.3 \\
7.3\end{array}$ & $\begin{array}{l}21.0 \\
15.9 \\
21.0\end{array}$ & $\begin{array}{l}11.2 \\
10.6 \\
10.9\end{array}$ & $\begin{array}{l}3.5 \\
2.5 \\
3.0\end{array}$ & $\begin{array}{l}31.45 \\
23.35 \\
27.37\end{array}$ \\
\hline UE5PU-3 & $\begin{array}{l}\text { DB1 } \\
\text { DR12 } \\
\text { Total }\end{array}$ & $\begin{array}{l}10 \\
13 \\
23\end{array}$ & $\begin{array}{l}4.9 \\
2.6 \\
2.6\end{array}$ & $\begin{array}{l}13.2 \\
10.7 \\
13.2\end{array}$ & $\begin{array}{l}8.6 \\
7.5 \\
7.9\end{array}$ & $\begin{array}{l}2.5 \\
2.3 \\
2.3\end{array}$ & $\begin{array}{l}29.06 \\
30.37 \\
20.73\end{array}$ \\
\hline
\end{tabular}


Table 3.3 Summary of descriptive statistics of alluvium samples from the Pilot Wells (continued).

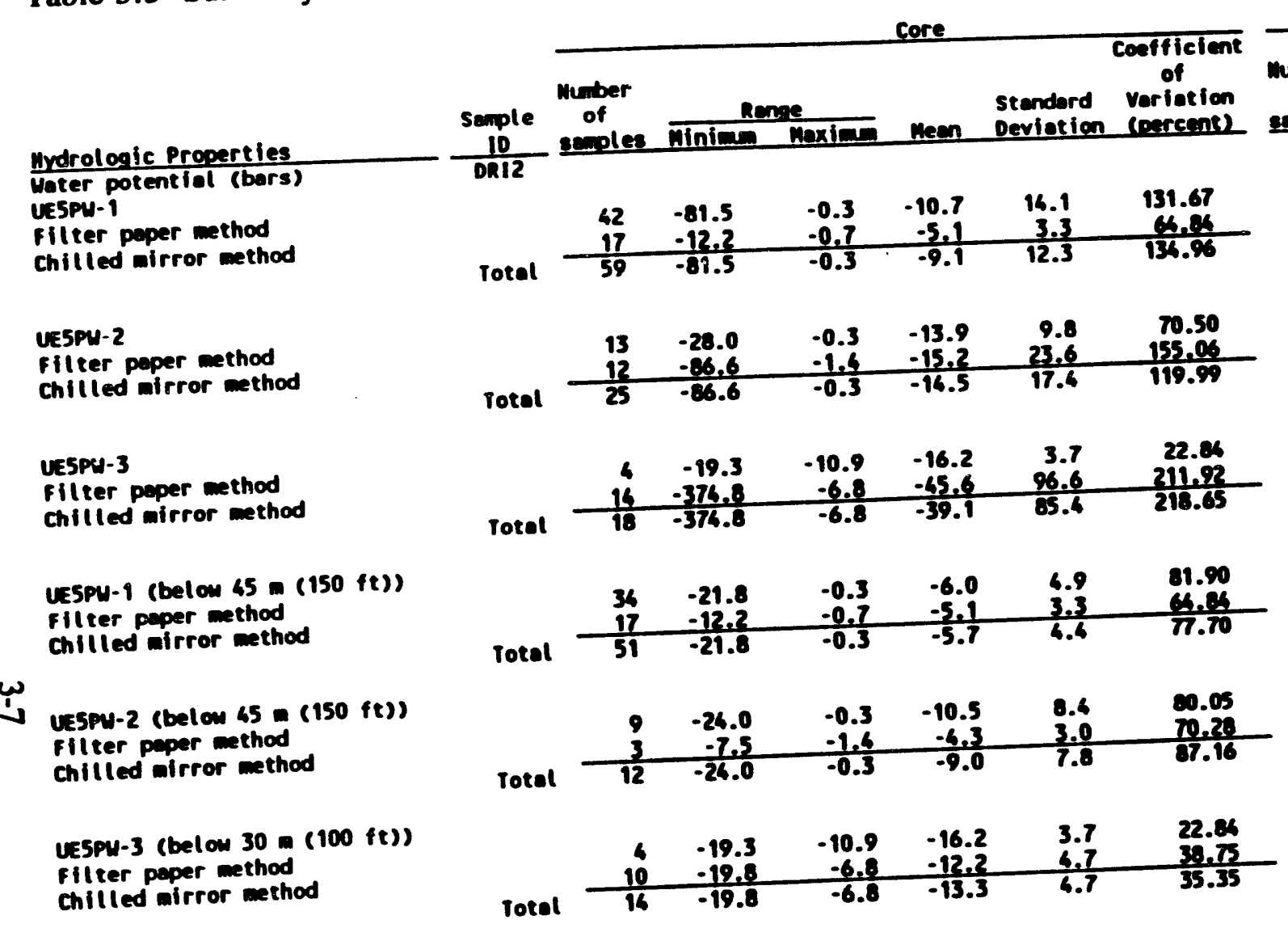


Table 3.3 Summary of descriptive statistics of alluvium samples from the Pilot Wells (continued).

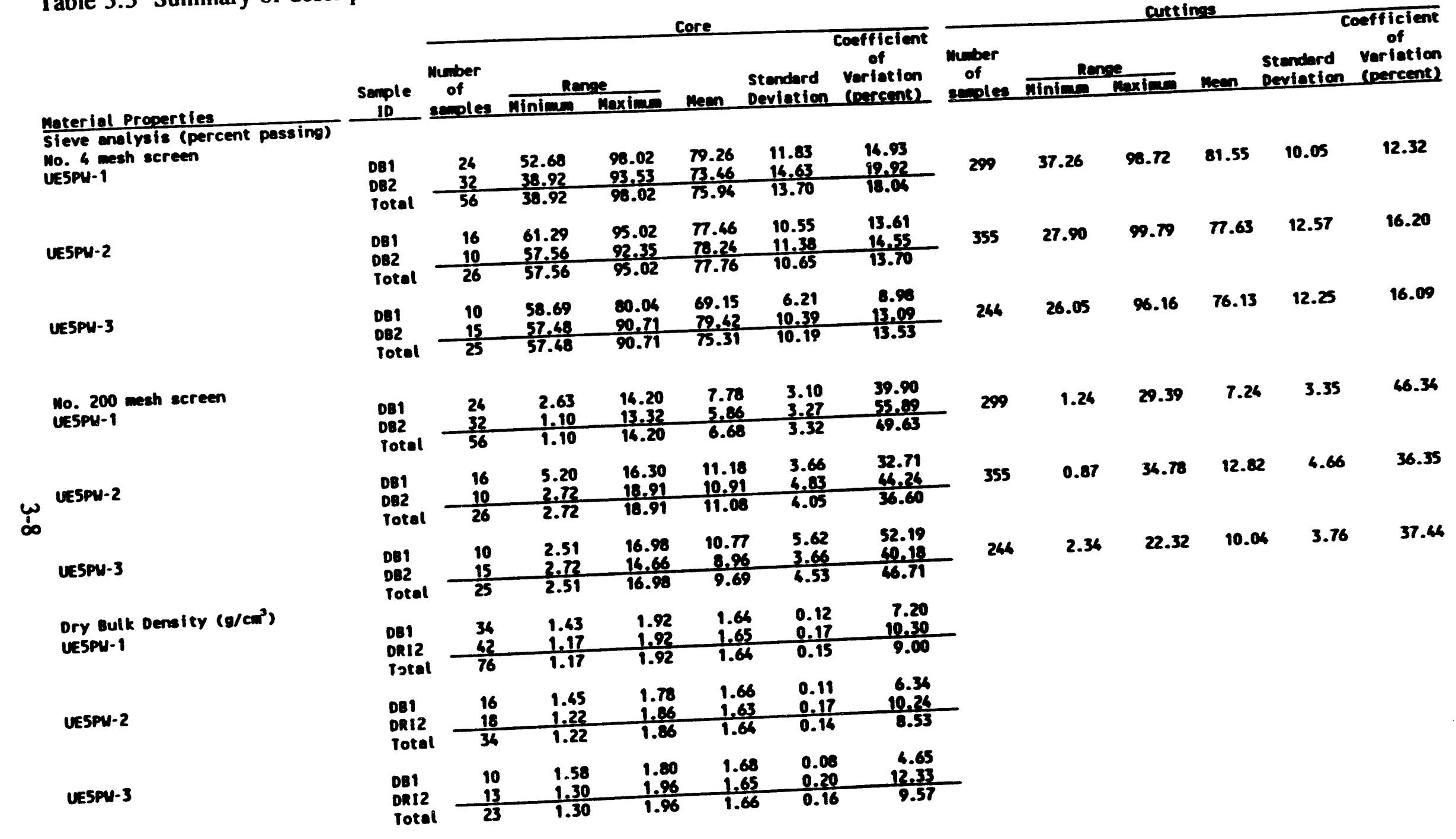


Table 3.3 Summary of descriptive statistics of alluvium samples from the Pilot Wells (continued).

\begin{tabular}{|c|c|c|c|c|c|c|c|c|c|c|c|c|c|}
\hline \multirow{4}{*}{$\begin{array}{l}\text { Material Properties } \\
\text { Porosity. colculated (percent) } \\
\text { UEspu-1 }\end{array}$} & \multirow{4}{*}{ 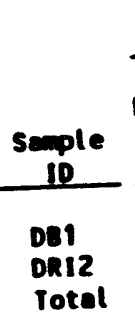 } & \multicolumn{6}{|r|}{ Coffletent } & \multicolumn{6}{|c|}{ coefficient } \\
\hline & & \multirow{3}{*}{$\begin{array}{l}\text { Muber } \\
\text { of } \\
\text { seneles } \\
36 \\
42 \\
76\end{array}$} & \multicolumn{2}{|c|}{$\frac{\text { Rene }}{\text { Menging }}$} & \multirow{3}{*}{$\begin{array}{l}\text { Meen } \\
30.07 \\
37.81 \\
37.93\end{array}$} & \multirow{2}{*}{$\begin{array}{l}\text { Standerd } \\
\text { Devintien }\end{array}$} & \multirow{2}{*}{$\begin{array}{l}\text { Confficient } \\
\text { of } \\
\text { Verfotion } \\
\text { (earesent) }\end{array}$} & \multirow{2}{*}{$\begin{array}{l}\text { mor } \\
\text { of } \\
\text { entes }\end{array}$} & \multicolumn{2}{|c|}{ nen } & \multirow{2}{*}{$\operatorname{men}$} & \multirow{2}{*}{$\begin{array}{l}\text { Co } \\
\text { Stendard } \\
\text { Devietion }\end{array}$} & \multirow{2}{*}{$\begin{array}{l}\text { Coefficient } \\
\text { of } \\
\text { veriation } \\
\text { (oxarent) }\end{array}$} \\
\hline & & & Mining & Maxien & & & & & Minies & & & & \\
\hline & & & $\begin{array}{r}27.53 \\
27.55 \\
27.53\end{array}$ & $\begin{array}{l}45.87 \\
55.85 \\
55.85\end{array}$ & & $\begin{array}{r}4.45 \\
6.60 \\
5.50\end{array}$ & $\begin{array}{l}11.68 \\
\frac{16.98}{16.71}\end{array}$ & & & & & & \\
\hline UESPU-2 & $\begin{array}{l}\text { D81 } \\
\text { DR12 } \\
\text { Total }\end{array}$ & $\begin{array}{l}16 \\
18 \\
36\end{array}$ & $\begin{array}{l}32.91 \\
29.81 \\
29.81\end{array}$ & $\begin{array}{l}65.36 \\
56.60 \\
56.60\end{array}$ & $\begin{array}{l}37.36 \\
60.06 \\
38.79\end{array}$ & $\frac{3.96}{7.27}$ & $\begin{array}{l}10.55 \\
18.15 \\
15.50\end{array}$ & & & & & & \\
\hline UESPN-3 & $\begin{array}{l}\text { De1 } \\
\text { DR12 } \\
\text { Total }\end{array}$ & $\begin{array}{l}10 \\
13 \\
23\end{array}$ & $\begin{array}{l}32.15 \\
26.06 \\
26.06\end{array}$ & $\begin{array}{l}40.26 \\
50.96 \\
50.96\end{array}$ & $\begin{array}{l}36.51 \\
37.85 \\
37.27\end{array}$ & $\begin{array}{l}2.90 \\
7.66 \\
5.99\end{array}$ & $\begin{array}{r}7.94 \\
29.26 \\
16.00\end{array}$ & & & & & & \\
\hline $\begin{array}{l}\text { Porosity, senturated (percent) } \\
\text { UESPW-1 }\end{array}$ & De1 & 24 & 27.50 & 39.20 & 33.50 & 3.39 & 10.12 & & & & & & \\
\hline UESPU-2 & Da1 & 16 & 27.93 & $39 . \pi$ & 32.70 & 3.61 & 10.42 & & & & & & \\
\hline UESPM-3 & De1 & 9 & 26.88 & 35.87 & 30.31 & 2.72 & 8.97 & & & & & & \\
\hline $\begin{array}{l}\text { Mogentic susceptibility } \\
\text { VESPU-1 }\end{array}$ & & 195 & 0.5 & 5.0 & 2.1 & 1.0 & 45.68 & 200 & 0.7 & 4.5 & 2.1 & 0.6 & 20.97 \\
\hline UESPU-2 & & 139 & 0.2 & 3.7 & 1.2 & 0.6 & 4.22 & 359 & 0.6 & 4.7 & 1.2 & 0.5 & 41.23 \\
\hline UESPU-3 & & 112 & 0.6 & 3.6 & 1.7 & 0.7 & 41.65 & 266 & 0.6 & 3.9 & 1.6 & 0.6 & 34.00 \\
\hline
\end{tabular}


Table 3.3 Summary of descriptive statistics $0 /$ alluviuni samples from the Pilot Wells (continued).

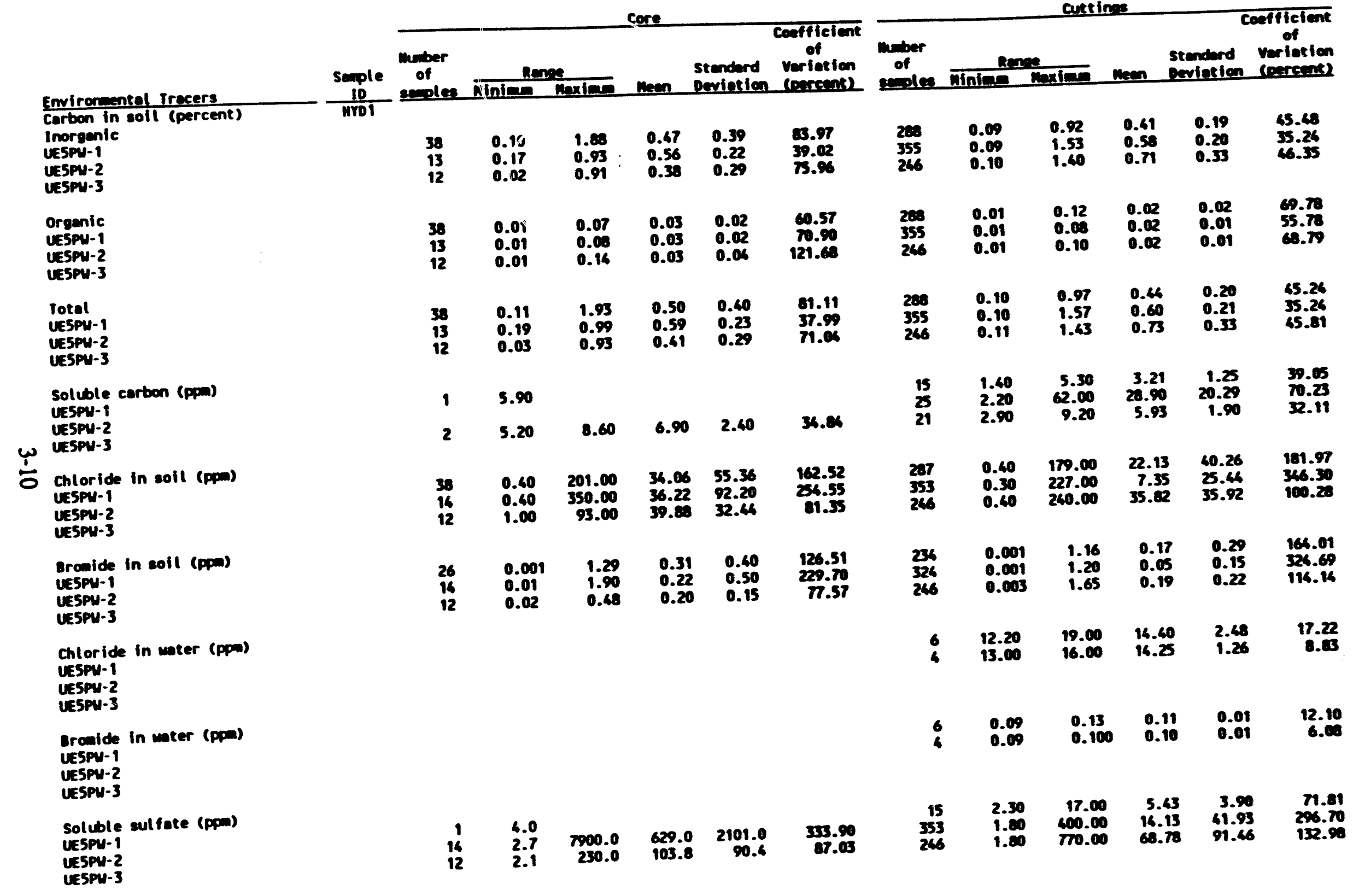


Table 3.3 Summary of descriptive statistics of alluvium samples from the Pilot Wells (continued).

Emironientel Trecers Carbon in soll (percent)

Inorgenic

UESPN-1 (belon $75=(250 \mathrm{ft})$

UEspu-2 (beton $30=(100 \mathrm{ft})$ )

Lespu-3 (belon 120 - $(400 \mathrm{ft})$

Organic

UESPU-1 (below $75=(250(t))$

UESPU-2 (beton 30 a (100 fe)

VESPU-3 (beton 120 a $(400 \mathrm{ft})$ )

Total

TE5PU-1 (belon $75=(250 \mathrm{ft})$ )

Lespu-2 (belon 30 (100 (t)

uespy-2 (belon 120 - (400 (t)

Soluble carbon (ppon)

(below $\pi 5=(250 \mathrm{ft})$

(250 (10)

UESPN-2 (belon $30=(100 \mathrm{ft})$

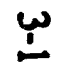

chloride in soll (ppo)

IESPU-1 (below $75=(250 \mathrm{ft})$ ) UEsp 2 (belon $30(100 \mathrm{ft})$ 120 - (400 (t)

Dramide in soll (ppa)

UEspu-1 (betou $75=(250 \mathrm{ft})$ )

$30=(100(2))$

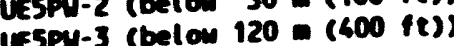

Soluble sulfate (ppo)

S=5Pu-1 (below $75=(250 \mathrm{ft}))$

(Espu-2 (belon $30=(100 \mathrm{ft})$ )

IEspu-3 (belou 120 in (600 ft)

UESPU- $18^{10} \mathrm{O}$

UESPU- $26^{10} \mathrm{O}$

UESPU-38'0

VESPU-180

UESPU-280

UESPU-300
Core

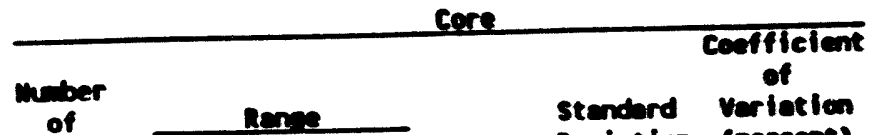

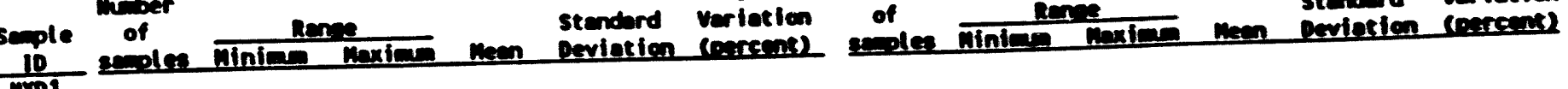

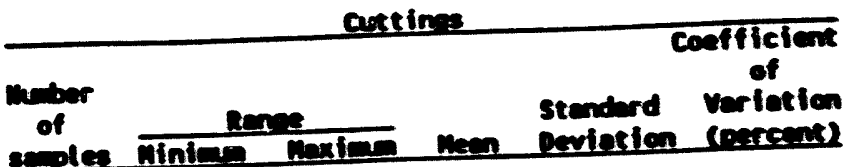

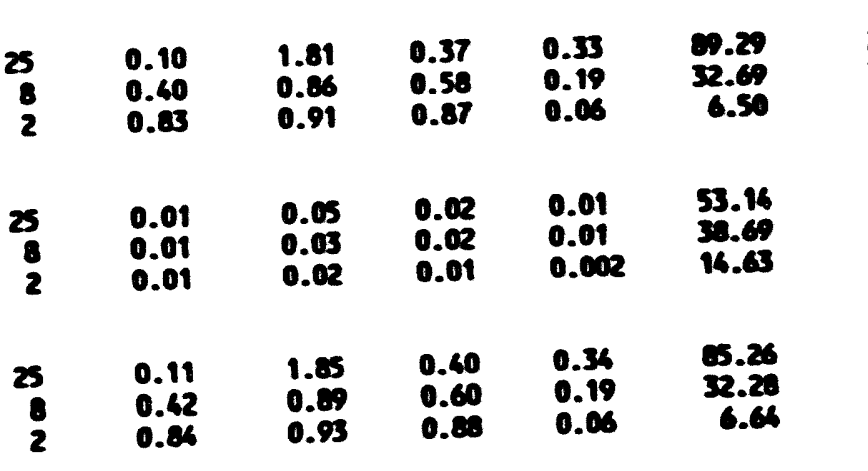

$\begin{array}{llllll}205 & 0.09 & 0.86 & 0.60 & 0.10 & 39.21\end{array}$

$\begin{array}{llllll}319 & 0.09 & 1.23 & 0.55 & 0.17 & 39.29 \\ 86 & 0.50 & 1.60 & 0.99 & 0.21 & 21.55\end{array}$

$\begin{array}{llllll} & 0.01 & 0.07 & 0.02 & 0.01 & 53.01\end{array}$

$\begin{array}{llllll}319 & 0.01 & 0.05 & 0.02 & 0.01 & 3.57 \\ 86 & 0.01 & 0.06 & 0.02 & 0.01 & 30.60\end{array}$

$\begin{array}{llllll}0.10 & 0.87 & 0.37 & 0.16 & 37.65\end{array}$

$\begin{array}{llllll}319 & 0.10 & 1.27 & 0.56 & 0.17 & 29.65 \\ 8 & 0.51 & 1.43 & 1.01 & 0.22 & 21.64\end{array}$

$\begin{array}{llllll}10 & 1.40 & 4.00 & 2.97 & 1.14 & 38.42\end{array}$

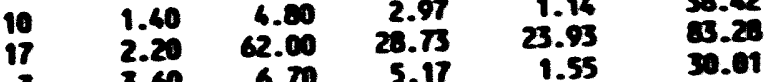

$\begin{array}{llll}0.40 & 0.60 \quad 1.15 & 0.93 & 01.08\end{array}$

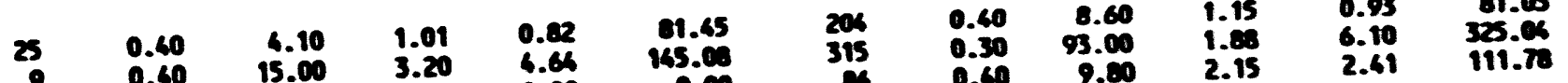

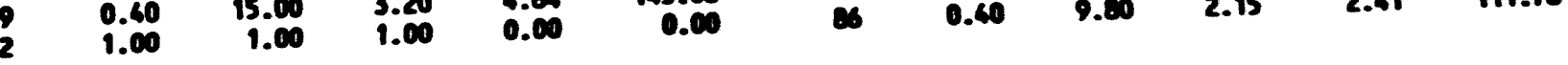

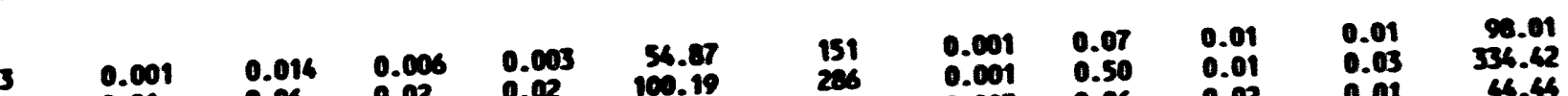

$\begin{array}{cccccccccccc}13 & 0.001 & 0.016 & 0.02 & 0.02 & 100.19 & 236 & 0.001 & 0.50 & 0.01 & 0.01 & 44.46\end{array}$

$\begin{array}{lllllll} & 0.02 & 0.02 & 0.02 & 0.0 & 0.0 & 0.02\end{array}$

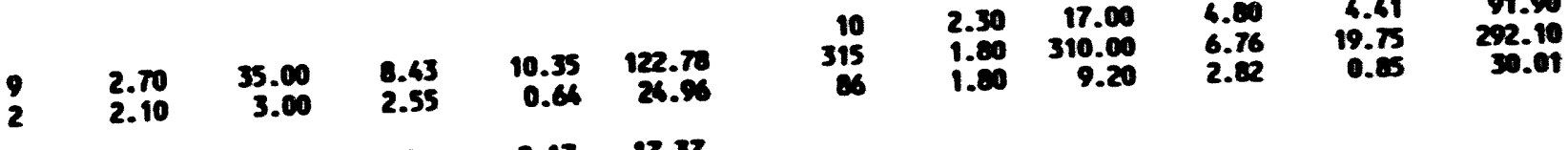

$\begin{array}{lllll}-16.5 & -6.6 & -12.5 & 2.17 & 17.37\end{array}$

$16 \quad-15.7 \quad-1.5 \quad-11.6 \quad 3.82 \quad 33.61$

$\begin{array}{llllll}15 & -16.6 & 4.8 & -10.8 & 6.00 & 56.20\end{array}$

$\begin{array}{llllll}22 & -114.0 & -69.0 & -106.2 & 6.83 & 6.43\end{array}$

$16-127.0 \quad-65.0 \quad-102.1$

$15 \quad-122.0 \quad-53.0-115.5$ 
Table 3.4 Summary of descriptive statistics of tuff samples from UESPW-3.

\begin{tabular}{|c|c|c|c|c|c|c|c|}
\hline \multirow[b]{2}{*}{ eromersin } & \multirow{2}{*}{$\frac{\text { sepple }_{10}}{10}$} & $\begin{array}{l}\text { Number } \\
\text { of }\end{array}$ & Inn & & Core & standard & $\begin{array}{c}\text { enfficiont } \\
\text { of } \\
\text { Veriation }\end{array}$ \\
\hline & & raples & Alning & Mndian & Mnn & Pevintion & (enrent) \\
\hline saturated conductivity (ea/s) & 081 & 3 & $6.0 \times 10^{-7}$ & $2.7 \times 10^{-6}$ & $1.6 \times 10^{-1}$ & $1.3 \times 10^{-8}$ & 93.09 \\
\hline Air permesbllity (ew/s) & & 3 & $2.0 \times 10^{-1}$ & $3.8 \times 10^{-6}$ & $2.8 \times 10^{-1}$ & $9.0 \times 10^{-6}$ & 32.46 \\
\hline Grovimerle metor centent (poreent) & $\begin{array}{l}\text { De1 } \\
\text { Del12 }\end{array}$ & $\begin{array}{r}3 \\
\frac{2}{5} \\
\end{array}$ & $\begin{array}{l}7.5 \\
0.8 \\
0.8\end{array}$ & $\begin{array}{l}7.6 \\
\frac{1.6}{7.6}\end{array}$ & $\begin{array}{l}7.6 \\
1.2 \\
5.0\end{array}$ & $\begin{array}{l}0.01 \\
0.57 \\
3.5\end{array}$ & $\begin{array}{r}0.13 \\
67.14 \\
69.65\end{array}$ \\
\hline Volumeric water content (parcent) & DE1 & 3 & 16.9 & 15.1 & 15.0 & 0.09 & 0.59 \\
\hline Woter potential (bars) & Da12 & 2 & .23 .2 & -16.3 & -19.8 & 4.90 & 24.56 \\
\hline Dry bulk denolty $\left(\mathrm{g} / \mathrm{cm}^{3}\right)$ & DA1 & 3 & 1.96 & 2.00 & 1.99 & 0.01 & 0.58 \\
\hline oruin density $\left(e / \mathrm{cm}^{3}\right)$ & DS1 & 3 & 2.57 & 2.38 & 2.57 & 0.01 & 0.22 \\
\hline Porealty, calculated (parcent) & 001 & 3 & 21.90 & 23.10 & 22.40 & 0.62 & 2.79 \\
\hline Pore volum (pereent) & D81 & 3 & 70.60 & 76.90 & r.e0 & 2.52 & 3.67 \\
\hline anmete sueratbllter & & 3 & 0.0 & $2 . \%$ & 0.7 & 1.17 & 156.57 \\
\hline
\end{tabular}

\begin{tabular}{|c|c|c|c|c|c|c|c|}
\hline \multirow[b]{3}{*}{$\begin{array}{l}\text { eropartins } \\
\text { orovimetric woter content (pareent) }\end{array}$} & \multirow[b]{3}{*}{$\begin{array}{l}\text { sapple } \\
\text { id } \\
\text { DhI2 } \\
\text { uro1 } \\
\text { Totel }\end{array}$} & \multicolumn{6}{|c|}{ Cutelines } \\
\hline & & & & & & standard & $\begin{array}{l}\text { ooffletiont } \\
\text { of } \\
\text { variation }\end{array}$ \\
\hline & & $\frac{19}{89}$ & $\begin{array}{c}\text { Minich } \\
0.6 \\
0.3 \\
0.3\end{array}$ & $\begin{array}{c}\text { Main. } \\
18.1 \\
3.6 \\
18.1\end{array}$ & $\begin{array}{l}\operatorname{Men} \\
3.6 \\
1.3 \\
1.8\end{array}$ & $\begin{array}{c}\text { Devineion } \\
4.53 \\
0.81 \\
2.66\end{array}$ & $\begin{array}{c}\text { (oxrenes) } \\
131.84 \\
60.45 \\
133.52\end{array}$ \\
\hline Water potential (bars) & Dn12 & 19 & -381.9 & -2.7 & -102.7 & 98.61 & \%.01 \\
\hline Maconetic susceptibillty & & 135 & 0.5 & 4.4 & 1.9 & 0.9 & 46.05 \\
\hline $\begin{array}{l}\text { Inorganic corben (parcent) } \\
\text { orgenic cerben (percent) } \\
\text { Total carbon (parcent) }\end{array}$ & 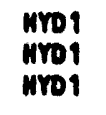 & $\begin{array}{r}66 \\
131 \\
66\end{array}$ & $\begin{array}{l}0.01 \\
0.002 \\
0.013\end{array}$ & $\begin{array}{l}1.19 \\
0.04 \\
1.20\end{array}$ & $\begin{array}{l}0.34 \\
0.01 \\
0.35\end{array}$ & $\begin{array}{l}0.33 \\
0.01 \\
0.33\end{array}$ & $\begin{array}{l}96.17 \\
67.60 \\
96.31\end{array}$ \\
\hline Soluble organic carbon (ppom) & MYDI & 3 & 2.8 & 20.60 & 10.30 & 9.24 & 90.00 \\
\hline $\begin{array}{l}\text { Chloride in soll (pom) } \\
\text { Bromide in soil (ppm) } \\
\text { solyble sulfete (oom) }\end{array}$ & $\begin{array}{l}\text { nYol } \\
\text { HYo1 } \\
\text { HYoI } \\
\end{array}$ & $\begin{array}{l}134 \\
129 \\
134 \\
\end{array}$ & $\begin{array}{l}0.30 \\
0.001 \\
0.7\end{array}$ & $\begin{array}{r}6.30 \\
0.05 \\
17.40 \\
\end{array}$ & $\begin{array}{l}2.00 \\
0.01 \\
2.80 \\
\end{array}$ & $\begin{array}{l}1.37 \\
0.01 \\
2.86\end{array}$ & $\begin{array}{r}68.06 \\
82.76 \\
102.44 \\
\end{array}$ \\
\hline
\end{tabular}




\subsubsection{General Geologic, Lithologic, and Stratigraphic Data for Alluvium}

Visual geologic descriptions were made on both core and drill cuttings samples (Sections 2.3.1 and 2.3.2) and recorded on Borehole Log Sheets (Appendix B.1 to B.3) and field notebooks. These included a field description of lithology, texture, color, cementation, and reaction to hydrochloric acid. Field descriptions of texture (particle size distribution) were not as accurate as the textural classifications based on laboratory dry sieve analyses. Therefore, the laboratory textural classifications were added to the edited versions of the Borehole Log Sheets. This geologic descriptive information is summarized below.

The alluvial core and drill cuttings clasts were primarily tuff with occasional quarzite and limestone. Basalt clasts were even rarer and only identified in several samples. The degree of welding in the tuff clasts (observable only in large clasts) ranged from welded to nonwelded. These samples were generally weakly cemented to uncemented and exhibited a weak to strong reaction to dilute hydrochloric acid. Poorly-graded gravels and coarse-sand fractions were more subangular than well-graded fractions of similar particle size. Cobbles were generally subrounded. The general color of the alluvial samples was predominantly very pale brown to light yellowish brown. Gravels, when separated from other size fractions, were pink and gray in color.

The Unified Soil Classification System (USCS) textural data are summarized for all alluvial core and drill cuttings samples in Table 3.5. The justification for combining core and drill cuttings particle size distribution is given in Section 3.2. Note that this table includes particle size distribution data from each drill cuttings interval and from two core segments (DB1 and DB2 samples) in every core run. These textural classes are composed primarily of sand with silt, some gravel, and no clay. The predominant textural group found in all Pilot Wells is well-graded sand with silt (SW-SM). The second most frequently occurring group is silty sand (SM) in UESPW-2 and UESPW-3, and well-graded sand (SW).

Preliminary stratigraphic columns (Appendix E.1.1) were prepared for each Pilot Well using particle size distribution data from each drill cuttings interval and one core segment (DB2) from each core run. In general these columns show, for all Pilot Wells, that the thickest layers consist of sand with silt (SW-SM) and silty sand (SM). These layers altemate with thinner layers of poorly graded sand (SP), poorly graded sand with silt (SP-SM), well-graded sand (SW), and gravel zones. Some subtle differences in textural groups between each Pilot Well are briefly outlined below.

In UESPW-1 textural units consist predominantly of well-graded sand with silt (SW-SM) with a maximum thickness of $8.2 \mathrm{~m}$ (27 ft); numerous layers of well-graded sand with gravel (SW) with a maximum thickness of $5.2 \mathrm{~m}(17 \mathrm{ft})$, but more commonly 0.76 to $1.5 \mathrm{~m}$ $(2.5$ to $5 \mathrm{ft})$ thick; and less numerous and thinner layers of poorly graded sand (SP) and silty sand (SM). Textural units in UESPW-2 were composed primarily of silty sand (SM) with a maximum thickness of $12.2 \mathrm{~m}$ (40 ft); with numerous interbedded gravel zones and layers of well-graded sand with silt (SW-SM). Between 42.7 to $122.0 \mathrm{~m}$ (140 to $400 \mathrm{ft}$ ), as well as 
Table 3.5 Summary of USCS group names for core and drill cuttings samples from the Pilot Wells.

\begin{tabular}{|c|c|c|c|c|c|c|c|c|c|c|c|}
\hline \multirow[b]{2}{*}{ Borehole } & \multirow[b]{2}{*}{$\begin{array}{c}\text { Sample } \\
\text { Type }\end{array}$} & \multicolumn{9}{|c|}{ Number and percent () of samples with given USCS group names } & \multirow[b]{2}{*}{ TOTAL } \\
\hline & & SM & SP-SM & SW-SM & SP & sw & $\mathbf{G M}$ & GP & GW & GW-GM & \\
\hline UESPW-1 & $\begin{array}{c}\text { Drill } \\
\text { Cuttings }\end{array}$ & $\begin{array}{l}24 \\
(8)\end{array}$ & $\begin{array}{c}10 \\
(3.3)\end{array}$ & $\begin{array}{c}193 \\
(64.5)\end{array}$ & $\begin{array}{c}2 \\
(0.7)\end{array}$ & $\begin{array}{c}66 \\
(22.1)\end{array}$ & & & $\begin{array}{c}2 \\
(0.7)\end{array}$ & $\begin{array}{c}2 \\
(0.7)\end{array}$ & 299 \\
\hline UESPW-1 & Core & $\begin{array}{c}5 \\
(8.9)\end{array}$ & $\begin{array}{c}5 \\
(8.9)\end{array}$ & $\begin{array}{c}24 \\
(42.8)\end{array}$ & $\begin{array}{c}1 \\
(1.8)\end{array}$ & $\begin{array}{c}19 \\
(34.0)\end{array}$ & & & $\begin{array}{c}2 \\
(3.6)\end{array}$ & & 56 \\
\hline UE5PW-2 & $\begin{array}{c}\text { Drill } \\
\text { Cuttings }\end{array}$ & $\begin{array}{c}192 \\
(54.1)\end{array}$ & $\begin{array}{c}3 \\
(0.8)\end{array}$ & $\begin{array}{c}131 \\
(36.9)\end{array}$ & $\stackrel{1}{1}$ & $\begin{array}{c}10 \\
(2.8)\end{array}$ & $\begin{array}{c}1 \\
(0.3)\end{array}$ & $\begin{array}{c}1 \\
(0.3)\end{array}$ & & $\begin{array}{c}16 \\
(4.5)\end{array}$ & 355 \\
\hline UESPW-2 & Core & $\begin{array}{c}10 \\
(38.5)\end{array}$ & & $\begin{array}{c}15 \\
(57.7)\end{array}$ & $\begin{array}{c}1 \\
(3.8)\end{array}$ & & & & & & 26 \\
\hline UESPW-3 & $\begin{array}{c}\text { Drill } \\
\text { Cuttings }\end{array}$ & $\begin{array}{c}71 \\
(29)\end{array}$ & & $\begin{array}{l}149 \\
(61)\end{array}$ & & $\begin{array}{c}11 \\
(4.5)\end{array}$ & & $\begin{array}{c}2 \\
(1)\end{array}$ & $\begin{array}{l}2 \\
\text { (1) }\end{array}$ & $\begin{array}{c}9 \\
(3.5)\end{array}$ & $\begin{array}{r}244 \\
25\end{array}$ \\
\hline UESPW-3 & Core & $\begin{array}{c}9 \\
(36)\end{array}$ & & $\begin{array}{c}12 \\
(48)\end{array}$ & & $\begin{array}{c}4 \\
(16)\end{array}$ & & & & & \\
\hline TOTAL & & $\begin{array}{c}311 \\
(31.0)\end{array}$ & $\begin{array}{c}18 \\
(1.8)\end{array}$ & $\begin{array}{c}524 \\
(52.1)\end{array}$ & $\begin{array}{c}5 \\
(0.5)\end{array}$ & $\begin{array}{c}110 \\
(10.9)\end{array}$ & $\begin{array}{c}1 \\
(0.1)\end{array}$ & $\begin{array}{c}3 \\
(0.3)\end{array}$ & $\begin{array}{c}6 \\
(0.6)\end{array}$ & $\begin{array}{c}27 \\
(2.7)\end{array}$ & 1005 \\
\hline $\begin{array}{r}\text { 'SM: } \\
\text { SP-SM: } \\
\text { SW-SM: } \\
\text { SP: }\end{array}$ & $\begin{array}{l}\text { Silty sand (greate } \\
\text { Poorly-graded sa } \\
\text { Well-graded sand } \\
\text { Poorly-graded sa }\end{array}$ & $\begin{array}{l}\text { than } 12 \mathrm{pe} \\
\text { with silt } \\
\text { vith silt (5 } \\
\text { (less thar }\end{array}$ & $\begin{array}{l}\text { cent silt) } \\
\text { j to } 12 \text { per } \\
\text { to } 12 \text { perce } \\
5 \text { percent }\end{array}$ & $\begin{array}{l}\text { silt) } \\
\text { silt) }\end{array}$ & & & $\begin{array}{r}\text { SW: } \\
\text { GM: } \\
\text { GP: } \\
\text { GW: } \\
\text { GW-GM: }\end{array}$ & $\begin{array}{l}\text { Well-g } \\
\text { Silly } 8 \\
\text { Poorly } \\
\text { Well-8 } \\
\text { Well-: }\end{array}$ & $\begin{array}{l}\text { ded sand } \\
\text { vel (great } \\
\text { raded gra } \\
\text { ded grave } \\
\text { ded grave }\end{array}$ & $\begin{array}{l}\text { ess than } 5 \text { pe } \\
\text { than } 12 \text { per } \\
\text { (less than } \\
\text { (less than } 5 \\
\text { with silt (5 }\end{array}$ & $\begin{array}{l}\text { cent silt) } \\
\text { ent silt) } \\
\text { percent silt) } \\
\text { ercent silt) } \\
12 \text { percent silt) }\end{array}$ \\
\hline
\end{tabular}


between 171 to $256 \mathrm{~m}$ (560 to $840 \mathrm{ft}$ ), the silty sand unit (SM) is fairly massive, less gravelly, and has fewer interbedded layers of well-graded sand (SW). Finally, UESPW-3 is composed mainly of well-graded sand with silt (SW-SM) with a maximum thickness of $27.4 \mathrm{~m}$ (90 ft). Between 38.1 and $115.8 \mathrm{~m}$ (125 and $380 \mathrm{ft}$ ) the well-graded sand and silt unit is fairly massive, but from 115.8 to $170.7 \mathrm{~m}$ (380 to $560 \mathrm{ft}$ ) there is an increase in the number of silty sand (SM) layers. Below $170.7 \mathrm{~m}$ (560 ft) the silty sand layer is quite massive with scatter zones of cobbles and boulders.

It is not surprising that these preliminary stratigraphic columns show no correlation between textural units in the Pilot Wells separated by approximately $1,500 \mathrm{~m}$ (1 mi). The depositional processes that combine to form alluvial fans often interact to produce highly variable and discontinuous stratigraphies both in the lateral and vertical directions. This makes it difficult to correlate deposits between even closely spaced boreholes. For example, attempts to correlate deposits between the Science Trench Boreholes located only $15.2 \mathrm{~m}$ (50 ft) apart (and in some cases only $1.5 \mathrm{~m}$ [5 ft] apart) based solely on particle size distribution (REECo, 1993a) were unsuccessful.

Through observations of existing excavations within the Area 5 RWMS, stratigraphic units (based on a visual description of texture and a field interpretation of the depositional process involved) have been identified to extend laterally up to several hundreds of meters (Dozier and Rawlinson, 1991). However, a detailed comparison of the physical and hydrologic properties of these units indicated that the differences between units were neiither distinct nor statistically significant in most cases. Each unit is made up of textural groups that are nearly identical, the only difference is that one unit is slightly finer in texture than the other.

It should be emphasized that the inability to correlate textural units between the Pilot Wells and Science Trench Boreholes is not a significant problem in terms of understanding and simulating the movement of fluids in the regions between these boreholes. Sully et al. (1993), in a report prepared for submittal to a peer-reviewed professional journal, quantitatively demonstrate that the physical and hydrologic properties of these textural units (required to simulate fluid flow) are very similar. Therefore, the subsurface penetrated by both the Science Trench Boreholes and Pilot Wells can be approximated as a homogenous hydrogeologic system. Data and more qualitative arguments supporting this conclusion are presented Sections 3.2 and 3.3. Similar data and qualitative arguments have been presented for the Science Trench Boreholes (REECo, 1993a).

\subsubsection{Tuff Lithology and Stratigraphy}

Lithologic and stratigraphic descriptive data for the tuff units in UESPW-3 were obtained by examining a complete record of drill cuttings samples collected over consecutive $0.76-\mathrm{m}$ (2.5- $\mathrm{ft})$ depth intervals from the alluvium-tuff contact at $188.2 \mathrm{~m}(617.5 \mathrm{ft})$ to the total borehole depth at $291.1 \mathrm{~m}$ (955.0 ft). The detailed descriptive information presented below was obtained from an in-depth laboratory examination of the complete set of drill cuttings 
samples. Some general descriptive lithologic and stratigraphic information collected during drilling is presented in drill cuttings log sheets (Appendix B.6).

Two major lithologic and stratigraphic tuff units were penetrated in UESPW-3. A rhyolytic ash-flow tuff was encountered from 188.2 to $279.7 \mathrm{~m}$ (617.5 to $917.5 \mathrm{ft})$. Underlying this unit is a bedded tuff which extends at least to the total borehole depth. The ash-flow tuff unit has been identified as the Ammonia Tanks Member of the Timber Mountain Tuff Formation (Poole, 1965; Byers et al., 1976). This unit is of Tertiary age and grades from moderately welded at the alluvium-tuff contact to nonwelded at the bedded tuff contact. Further evidence for this gradation in welding is seen in the natural gamma logs presented in Section 4.3.2. The core samples from the tuff from 194.54 to $196.14 \mathrm{~m}$ (638.25 to $643.50 \mathrm{ft}$ ) and from 209.86 to $210.87 \mathrm{~m}$ (688.50 to $691.83 \mathrm{ft}$ ) (Table 2.5) sampled the moderately welded and partially welded sections of this unit, respectively.

The ash-flow unit is fairly uniformly gray in color with a matrix that is glassy to devitrified. Abundant phenocrysts are present (20 percent to 25 percent by volume), consisting of bronze and black biotite, sanidine, sphene, and plagioclase feldspar minerals. Structural features were not observed in either the core or the drill cuttings samples. Nearby outcrops of this unit in the Massachusetts Mountains indicate that this unit is dipping approximately $15^{\circ}$ to $25^{\circ}$ to the southeast. This significant dip may extend beneath UESPW-3 and in part accounts for the apparent 91.4-m (300-ft) thickness of this unit. A nearby drill hole, UEIla, penetrated this unit and is described as dipping $28^{\circ}$ to the southeast (Fernald et al., 1965).

The underlying bedded tuff unit has been reworked by water, is vitric and weakly calcareous, and contains abundant phenocrysts. The colors in the tuff include shades of red, orange, brown, and white. Overall, the bedded tuff is expected to exhibit a higher porosity and hydraulic conductivity than the overlying moderately welded to nonwelded ash-flow tuff (Winograd and Thordarson, 1975).

\subsubsection{Mineralogy}

Information on the mineralogy of soil materials is useful for identifying soil horizons with chemical properties that have the potential to affect the transport of contaminants. For example, certain waste components may adsorb strongly to certain mineral surfaces. Clay minerals, because of their large specific surface area and charge, may be particularly important for attenuating the transport of solutes. For this reason, selected core samples were sent to Sandia National Laboratories for identification of individual clay minerals by $\mathrm{X}$-ray diffraction. However, these analyses had not been completed at the date of publication of this report.

In addition, characterization of the gross elemental and oxide composition is helpful in identifying the source(s) of sediments and understanding the depositional history. This information is in turn useful in estimating the age and stability of pediments, and the 
potential for future erosion at the Area 5 RWMS. With this in mind, selected core samples were pulverized and subsampled for major element $\left(\mathrm{SiO}_{2}, \mathrm{TiO}_{2}, \mathrm{Al}_{2} \mathrm{O}_{3}, \mathrm{Fe}_{2} \mathrm{O}_{3}, \mathrm{MnO}, \mathrm{MgO}\right.$, $\mathrm{CaO}, \mathrm{Na}_{2} \mathrm{O}, \mathrm{K}_{2} \mathrm{O}$, and $\mathrm{P}_{2} \mathrm{O}_{5}$ ) and trace element ( $\mathrm{Rb}, \mathrm{Sr}, \mathrm{Zr}, \mathrm{Y}, \mathrm{Nb}, \mathrm{Pb}, \mathrm{Th}$ ) analysis by $\mathrm{X}$-ray fluorescence (XRF). The weight loss on ignition was also determined for each sample as a check on the quality of the analyses. Selected core samples were also analyzed for the following elements by instrumental neutron activation analysis (INAA): $\mathrm{FeO}, \mathrm{Na}_{2} \mathrm{O}, \mathrm{Sc}, \mathrm{Cr}$, $\mathrm{Zn}, \mathrm{As}, \mathrm{Br}, \mathrm{Sb}, \mathrm{Cs}, \mathrm{Ba}, \mathrm{La}, \mathrm{Ce}, \mathrm{Nd}, \mathrm{Sm}, \mathrm{Eu}, \mathrm{Tb}, \mathrm{Yb}, \mathrm{Lu}, \mathrm{Hf}, \mathrm{Ta}, \mathrm{Th}$, and U.

The completed results of element and oxide composition analysis for core samples from the Pilot Wells are given in Appendix E.1.2. Figures 3.1 and 3.2 illustrate the variation of elemental and oxide composition with depth in UESPW-1. Overall, the elemental and oxide composition of minerals remained fairly constant with depth. The results from the other two Pilot Wells also show that the mineralogy profiles are similar to UESPW-1. The variation of the data with depth is not significantly different than the variability noted in several Science Trench Boreholes located some 20 to $30 \mathrm{~m}$ to the southeast of UESPW-1 (REECo, 1993a).

These analyses further indicate that the samples from the Pilot Wells and the Science Trench Boreholes have the same general composition as the source rock for the alluvium at the Area 5 RWMS, that is, primarily Tertiary volcanics from the Massachusetts Mountains (Timber Mountain Tuff). These results were consistent with visual lithologic descriptions described in Section 3.1.2. The Tertiary volcanics, and subsequently the alluvium, have a basic rhyolitic composition of approximately 65 percent $\mathrm{SiO}_{2}$ and 13 percent $\mathrm{Al}_{2} \mathrm{O}_{3}$; all other major elements total less than 5 percent.

\subsubsection{Secondary Mineralogy and Organic Matter}

Depth profiles of inorganic carbon in alluvial drill cuttings samples for all three Pilot Wells are illustrated in Figure 3.3. Tabular values of inorganic and organic carbon measurements, as well as calculated values of total carbon for core and drill cuttings samples, are presented in Appendix E.2 for samples from the alluvium and Appendix E.3 for samples from the tuff and descriptive statistics for these data are summarized in Tables 3.3 and 3.4, respectively.

The data show that inorganic carbon concentrations are very low (mean values are less than 1 percent by weight) and nearly constant throughout the entire thickness of alluvium penetrated. The only noticeable interval of elevated inorganic carbon is in UESPW-2 from approximately 168 to $171 \mathrm{~m}$ (550 to $560 \mathrm{ft}$ ). Elevated levels of chloride, bromide, and sulfate were also measured in this thin interval, further indicating that this is a layer of secondary mineral accumulation that could possibly be called a caliche layer. However, it should be noted that there was no visible evidence in the core or drill cuttings samples of secondary mineral accumulation at this or any other depth interval in the Pilot Wells. Finally, the consistency in depth profiles of inorganic carbon concentrations also suggests that the source rock for the entire thickness of alluvium penetrated contained remarkably 

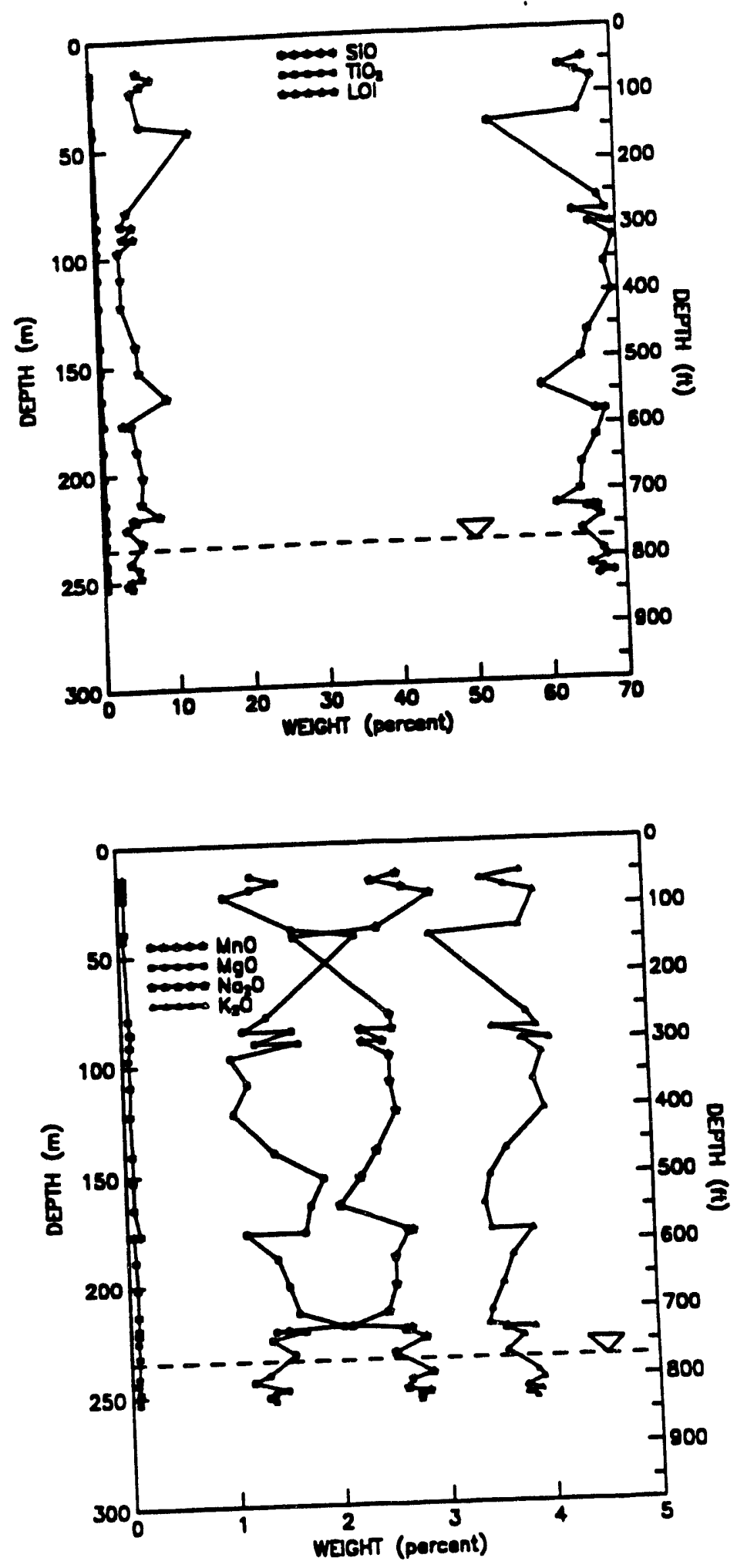

Figure 3.1 Depth profiles of element and oxide composition data by XRF for core samples from UESPW-1. 

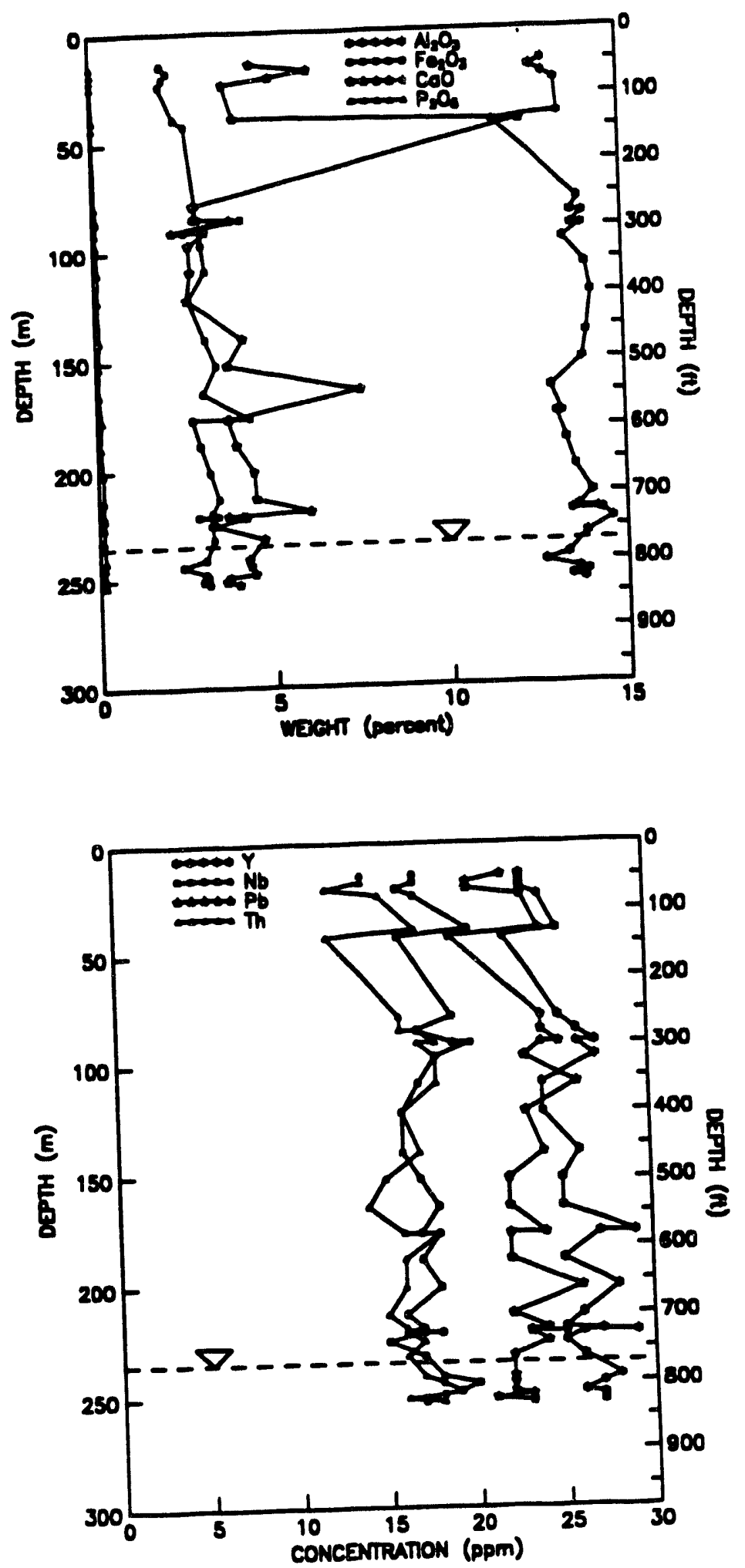

Figure 3.1 Depth profiles of element and oxide composition data by XRF for core samples from UESPW-1 (Continued). 


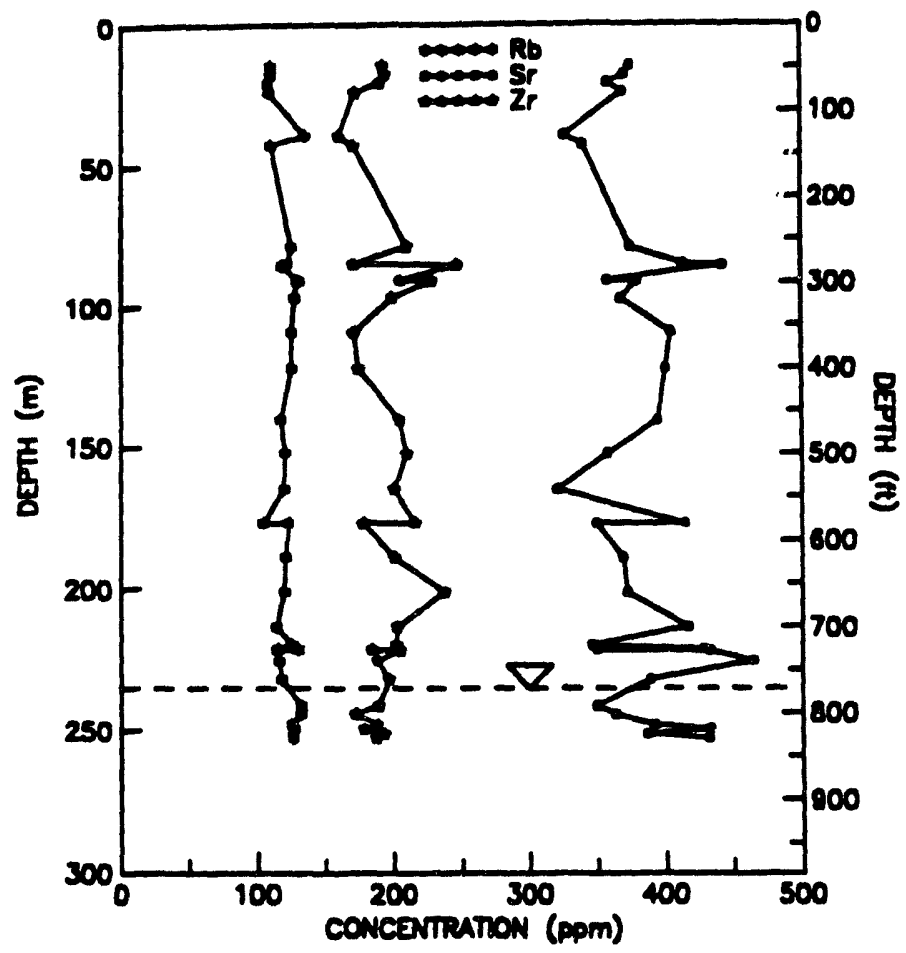

Figure 3.1 Depth profiles of element and oxide composition data by XRF for core samples from UESPW-1 (Continued). 

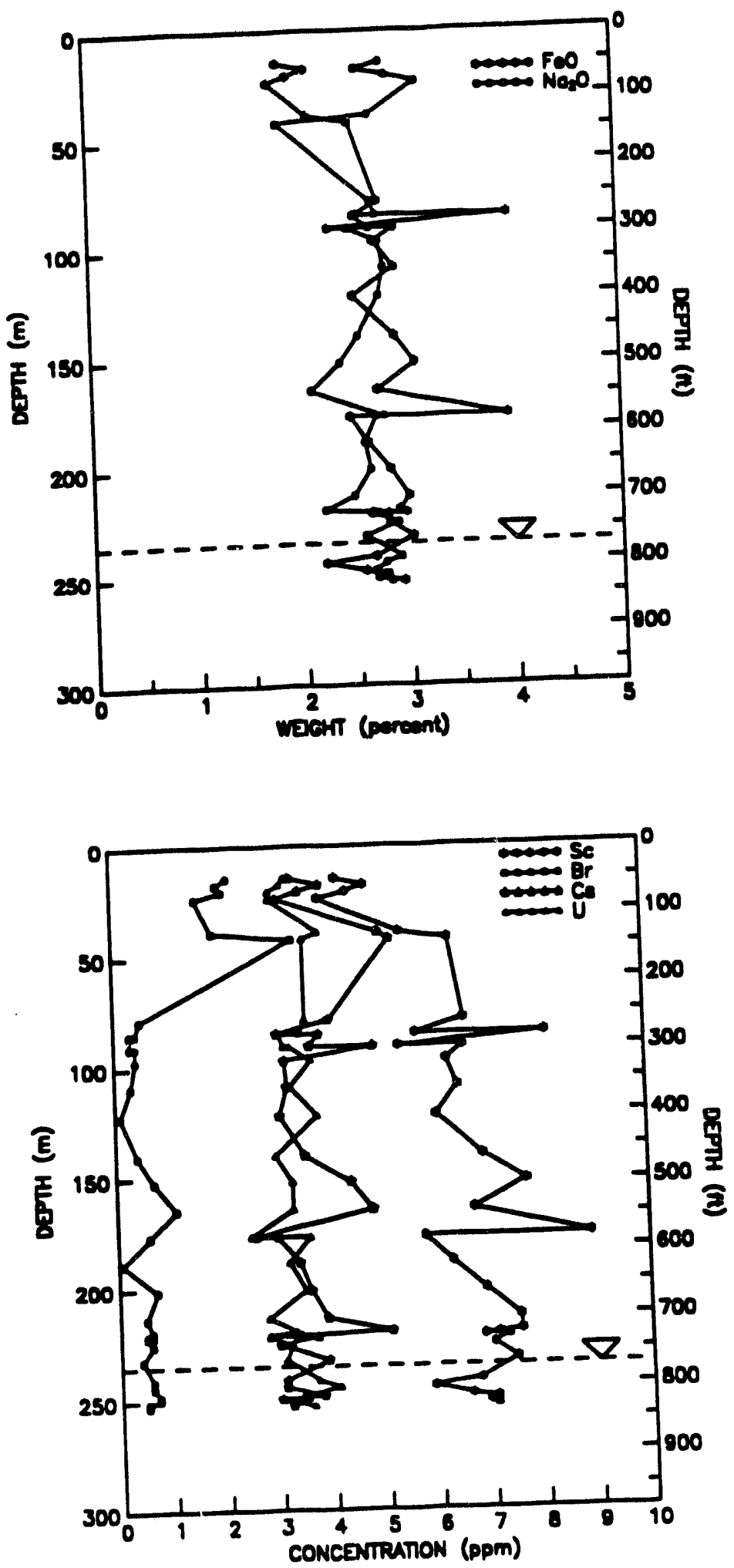

Figure 3.2 Depth profiles of element and oxide composition data by INAA for core samples from UESPW-1. 

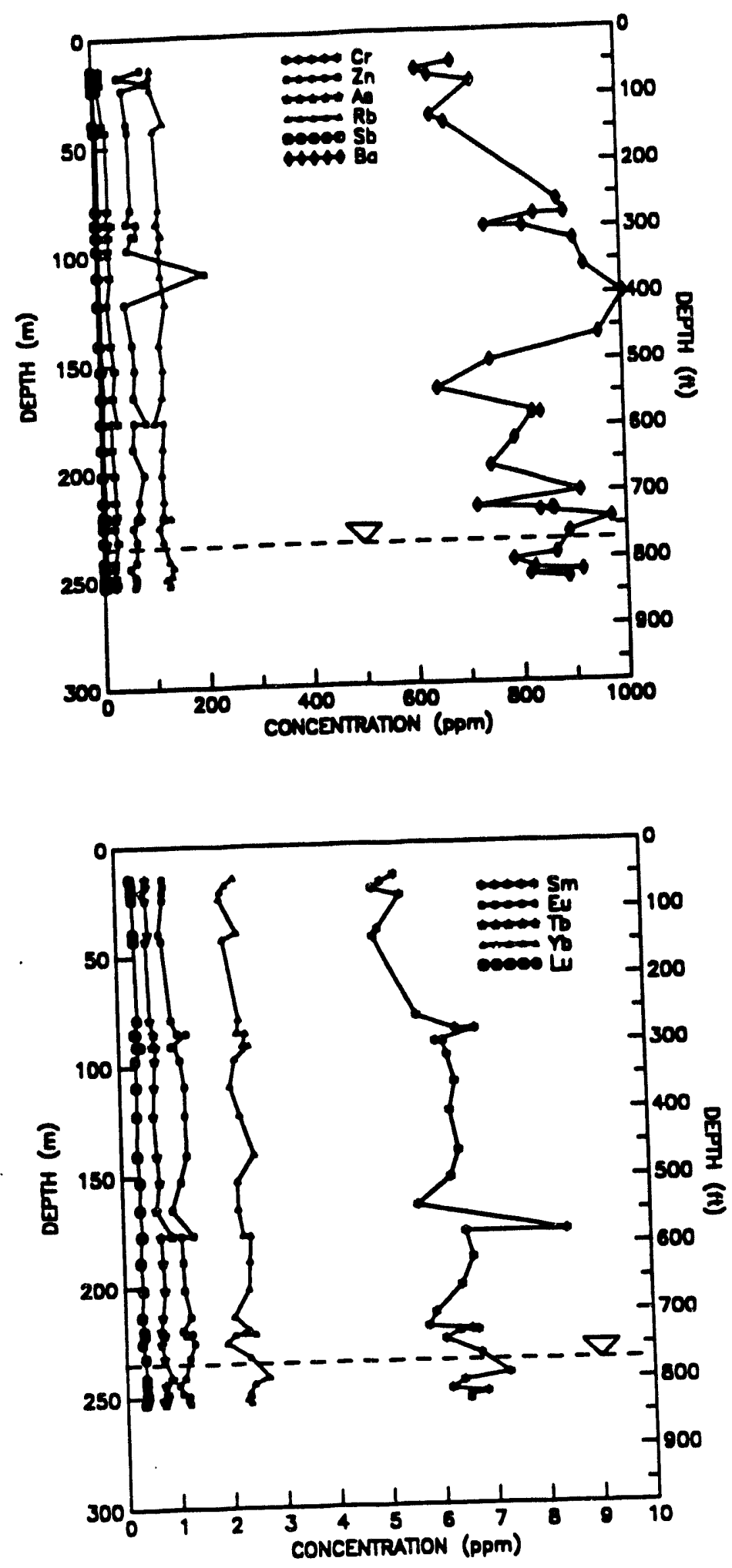

Figure 3.2 Depth profiles of element and oxide composition data by INAA for core samples from UESPW-1 (Continued). 


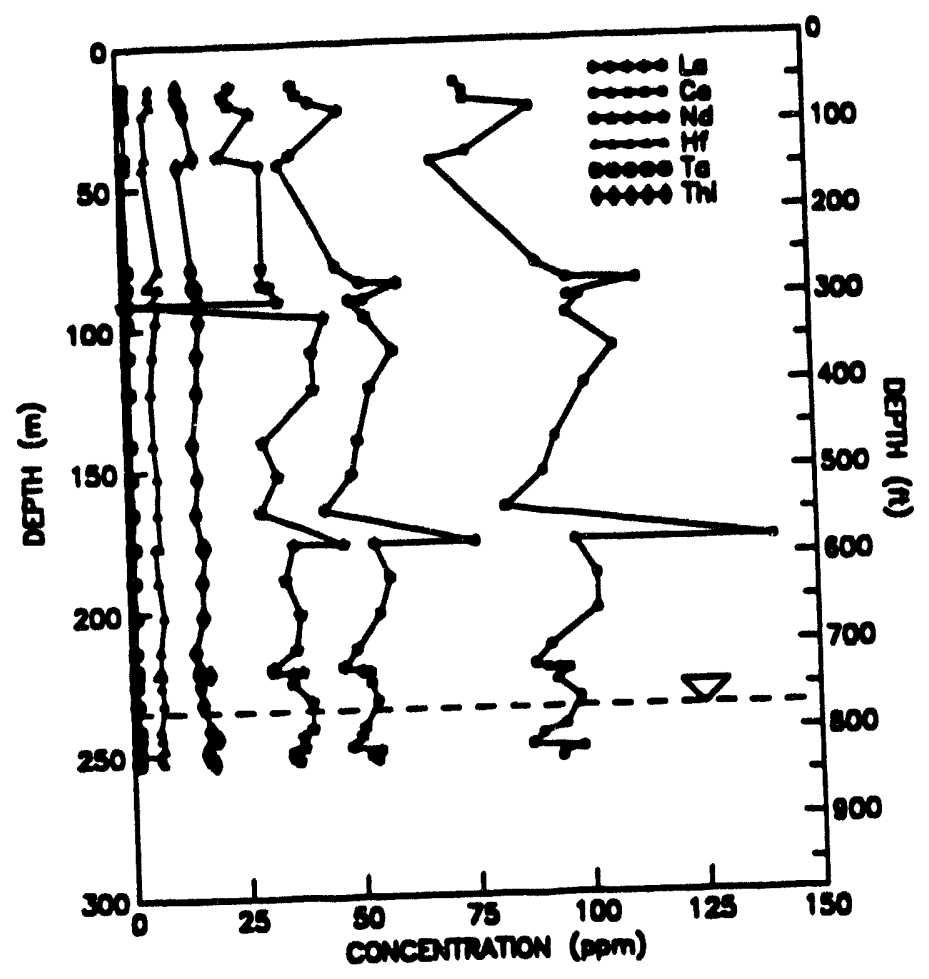

Figure 3.2 Depth profiles of element and oxide composition data by INAA for core samples from UESPW-1 (Continued). 


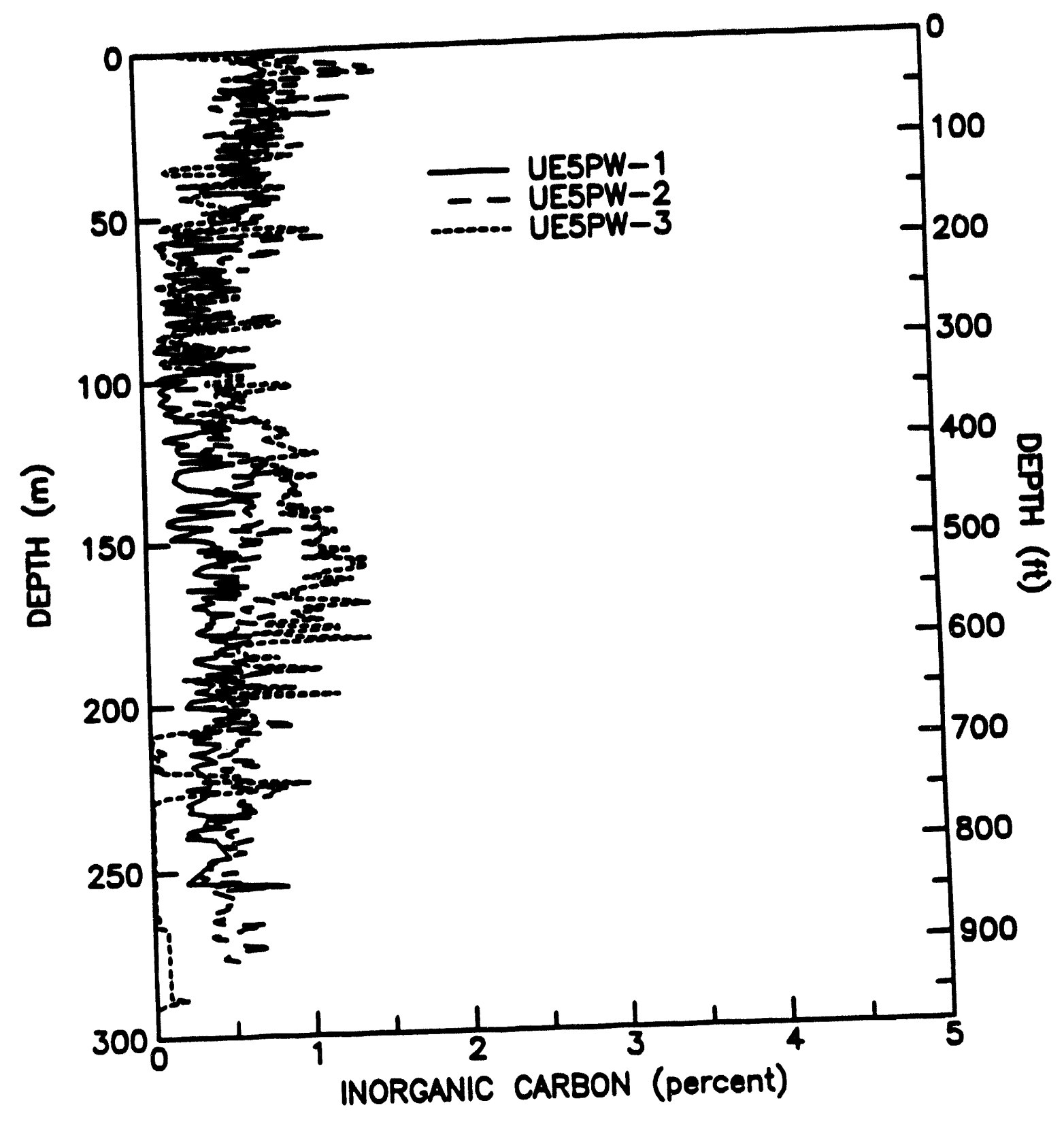

Figure 3.3 Depth profiles of inorganic carbon for drill cutting samples from the Pilot Wells. 
similar percentages of carbonates. This in turn suggests that the alluvial deposits originated from the same source rock.

Organic carbon values were generally an order of magnitude lower and equally as constant, demonstrating the absence of humus accumulation. The absence of caliche and humus layers helps support the argument (which will be expanded in the following sections) that the hydrogeologic system can be treated as a homogenous alluvial unit.

\subsection{Physical Properties}

Several physical properties are relatively easy and inexpensive to measure and provide valuable insight into understanding the hydrogeologic system beneath the Area 5 RWMS. These physical properties include particle size distribution, bulk density, and porosity. Bulk density and porosity measurements are dependent on the arrangement and degree of packing of unconsolidated alluvial particles, and therefore were made only on intact core samples. Particle size distributions of alluvial samples are independent of arrangement or packing and were determined on both intact core and drill cuttings samples. However, particle size distribution measurements are not appropriate for consolidated rock samples, and therefore were not conducted on tuff from UESPW-3.

\subsubsection{Particle Size Distribution}

Particle size distribution analyses were conducted on all alluvial drill cuttings samples collected at $0.76-\mathrm{m}(2.5-\mathrm{ft})$ intervals and on two $76.2-\mathrm{mm}$ (3-in) core segment from each core run (if available) using a dry sieve method. Previous analyses (REECo, 1993b) indicated only small differences between dry sieve and the much more expensive wet sieve methods on these relatively coarse-grained alluvial materials.

Since the sieve process destroys the physical integrity of the core samples, this test always followed a series of non-destructive physical and hydrologic tests on the same core sample. These precursor tests included saturated porosity, saturated hydraulic conductivity, and moisture retention measurements.

The results of particle size distribution analyses are presented in tabular form in Appendix E.2. Data from the No. 4 and No. 200 sieve screens (percent of material passing) for alluvial drill cuttings and core samples from UESPW-1, UE5PW-2, and UE5PW-3 are plotted vs. depth in Figures 3.4, 3.5, and 3.6, respectively. These figures illustrate the relative percent of materials falling into the gravel, sand, and silt/clay fractions at each depth and show that the particle size distribution of alluvial materials is remarkably similar with depth. These materials are predominantly composed of sand-sized particles with considerable amounts of gravel and usually contain less than 10 percent silt/clay. The small differences between core and drill cuttings profiles may be due to a number of geologic, drilling, and 


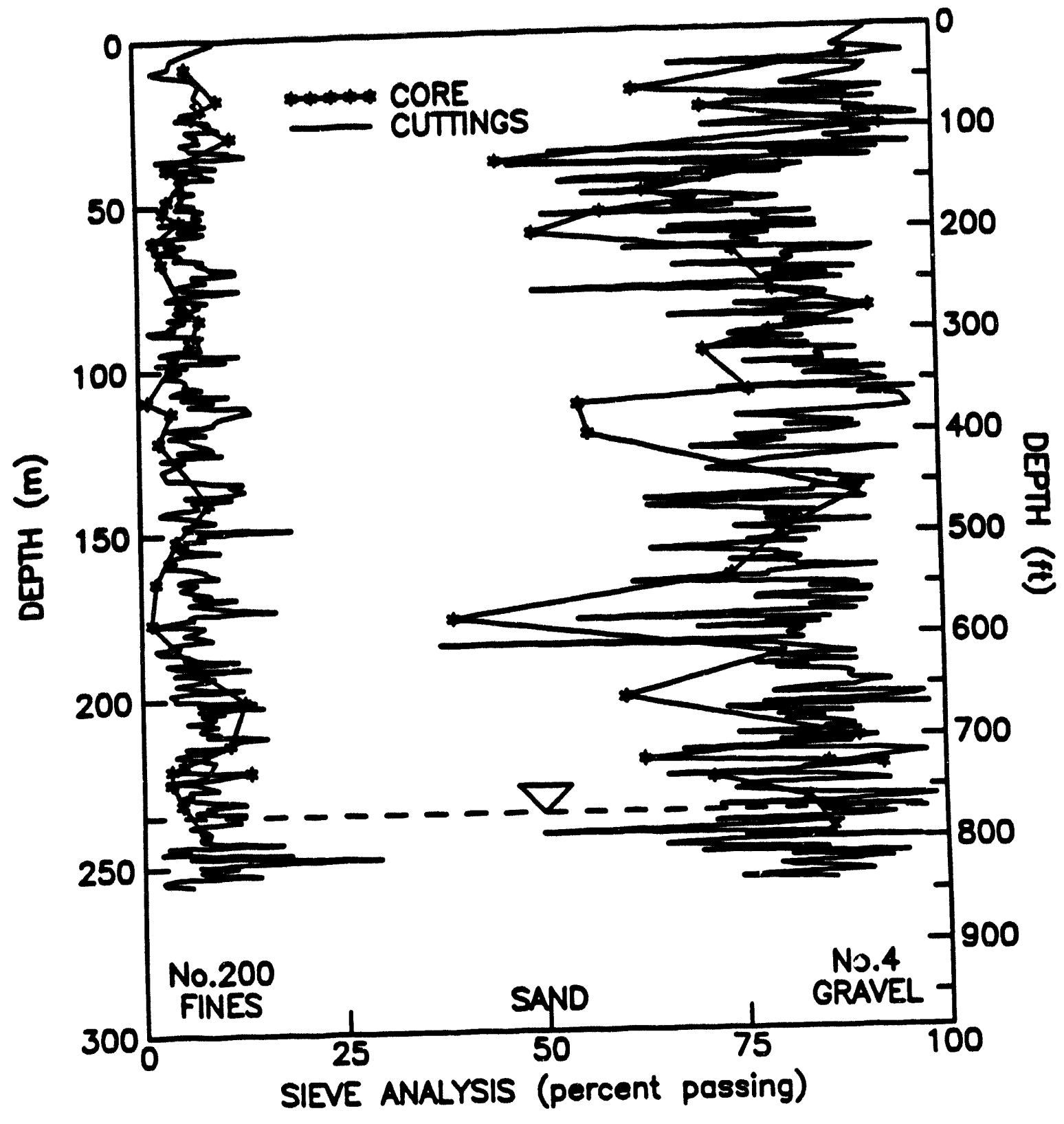

Figure 3.4 Depth profiles of dry sieve analyses (percent passing No. 4 and No. 200 mesh screens) for core and drill cuttings samples from UESPW-1. 


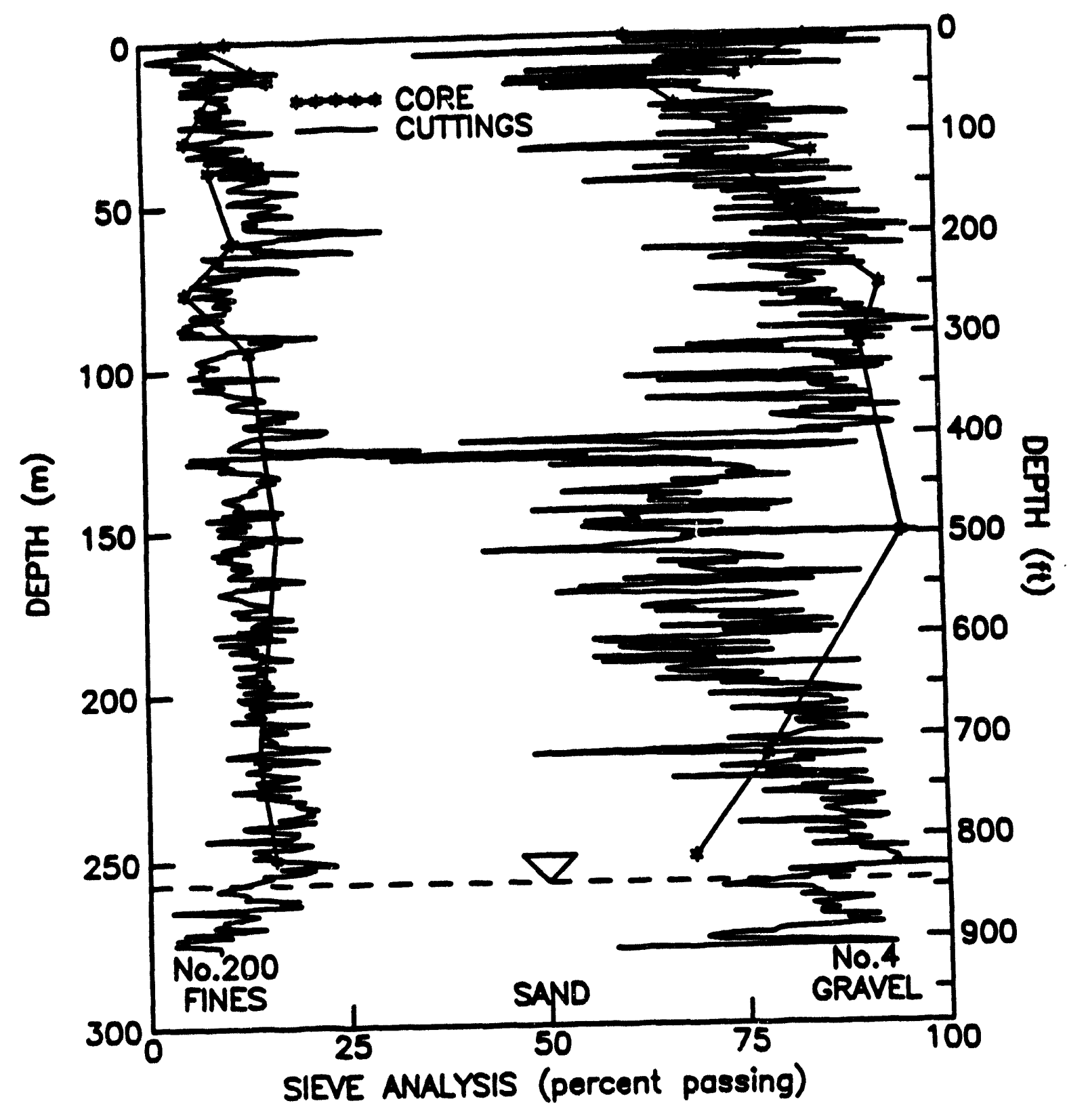

Figure 3.5 Depth profiles of dry sieve analyses (percent passing No. 4 and No. 200 mesh screens) for core and drill cuttings samples from UESPW-2. 


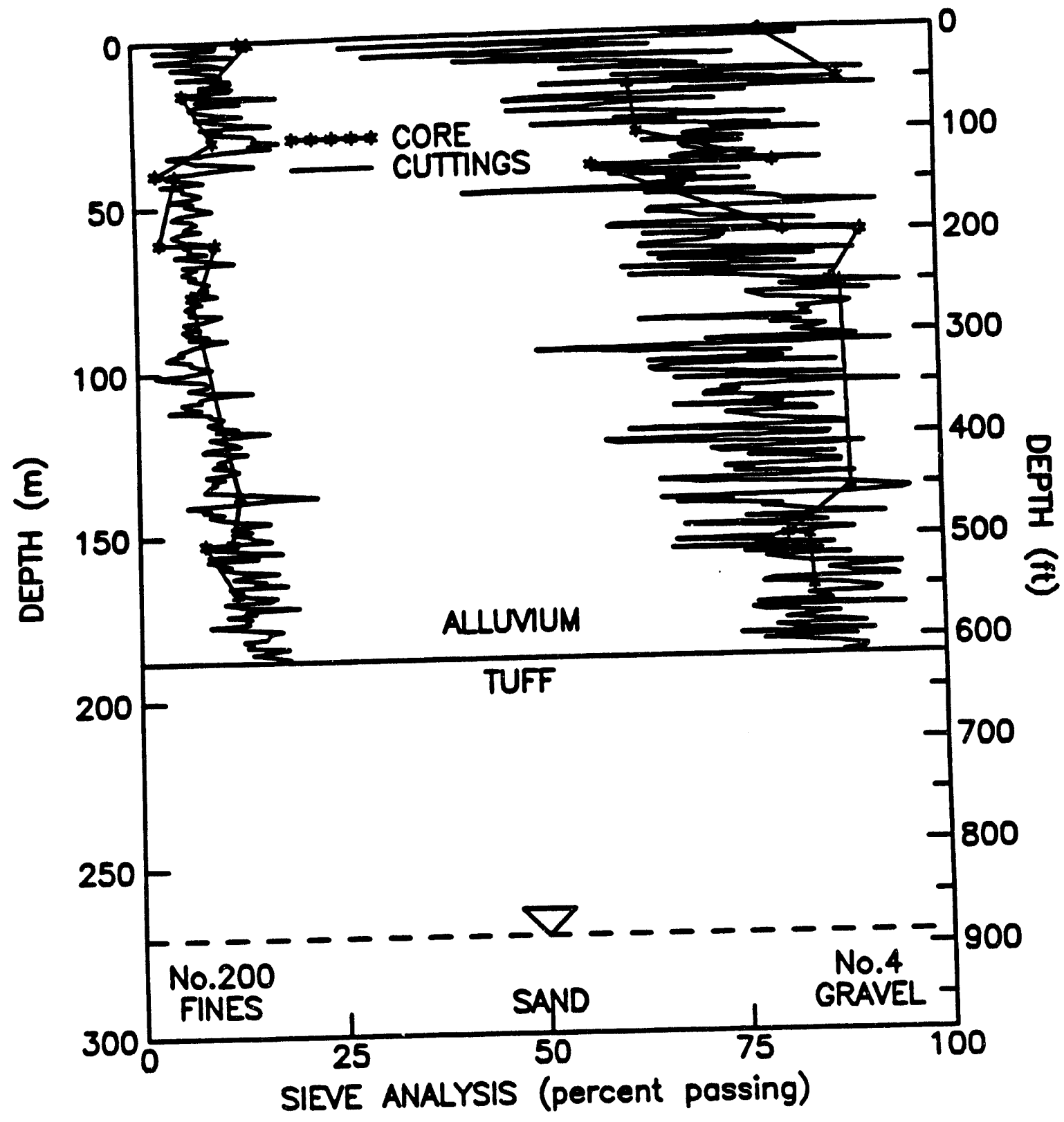

Figure 3.6 Depth profiles of dry sieve analyses (percent passing No. 4 and No. 200 mesh screens) for core and drill cuttings samples from UESPW-3. 
sampling-related factors. Apparently the different sample sizes (volumes) for core and drill cuttings is a factor.

Descriptive statistics of No. 4 and No. 200 sieve screen data for both core and drill cuttings from all three Pilot Wells are summarized in Table 3.3. These statistics have been calculated separately for different sample types as well as for the combined pool of samples from each borehole (Table 2.6). Mean values of percent silt/clay material in UESPW-2 appear to be significantly different from UESPW-1 and UESPW-3. However, mean values of this size fraction were very similar within each borehole. Mean values of the gravel fraction (material held on the No. 4 sieve) were very similar between holes for core samples but appear to significantly decrease from UESPW-1 to UESPW-3 for drill cuttings samples. This latter difference may be related to the ease and speed with which each borehole was drilled. The most drilling difficulty was encountered in UESPW-1 and the least was encountered in UESPW-3. This may suggest that air-percussion hammer drilling reduces the amount of gravel-sized particles under difficult drilling conditions.

\subsubsection{Bulk Density and Porosity}

Dry bulk densities were determined on two 76.2-mm (3-in) long core segments from each core run in alluvium and on $25.4-\mathrm{mm}(1-\mathrm{in})$ by $25.4-\mathrm{mm}$ plug subsamples from core in moderately welded tuff in UESPW-3. These data are presented in tabular form in Appendix E.2. Plots of alluvial bulk densities vs. depth for the Pilot Wells are presented in Figure 3.7. There appear to be no consistent trends in bulk densities with depth in the Pilot Wells. This may be due in part to the similarity of the particle size distribution (Section 3.2.1), consistency in lithology and mineralogy (Sections 3.1.2 and 3.1.3), and the near absence of secondary mineral cementing agents (Section 3.1.4).

Alluvial core porosities were calculated from dry bulk densities and using a particle density of approximately $2.65 \mathrm{~g} / \mathrm{cm}^{3}\left(165 \mathrm{lb} / \mathrm{ft}^{3}\right)$. In addition, water-saturated porosities were measured on alluvial core segments from all Pilot Wells following laboratory saturated hydraulic conductivity measurements made on the same core segment (Section 3.3.1). Both calculated and water-saturated porosities of samples from UESPW-1, UESPW-2, and UESPW-3 are plotted vs. depth in Figures 3.8, 3.9, and 3.10, respectively. Water saturated porosities were considerably lower than calculated porosities. Discussions with the testing laboratory indicate that the water-saturated porosities were in error resulting from unavoidable water loss (drainage) that occurs from the coarse-grained samples just prior to the measurement.

Descriptive statistics of dry bulk densities and porosities of alluvium samples are summarized in Table 3.3. Mean values and coefficients of variation of dry bulk densities and calculated porosities (by definition) for each Pilot Well were nearly identical. Dry bulk densities range from 1.17 to $1.96 \mathrm{~g} / \mathrm{cm}^{3}$ (73 to $\left.122 \mathrm{lb} / \mathrm{ft}^{3}\right)$. Bulk densities near both the lower and higher ends of the range may reflect sampling disturbance rather than in situ conditions. 


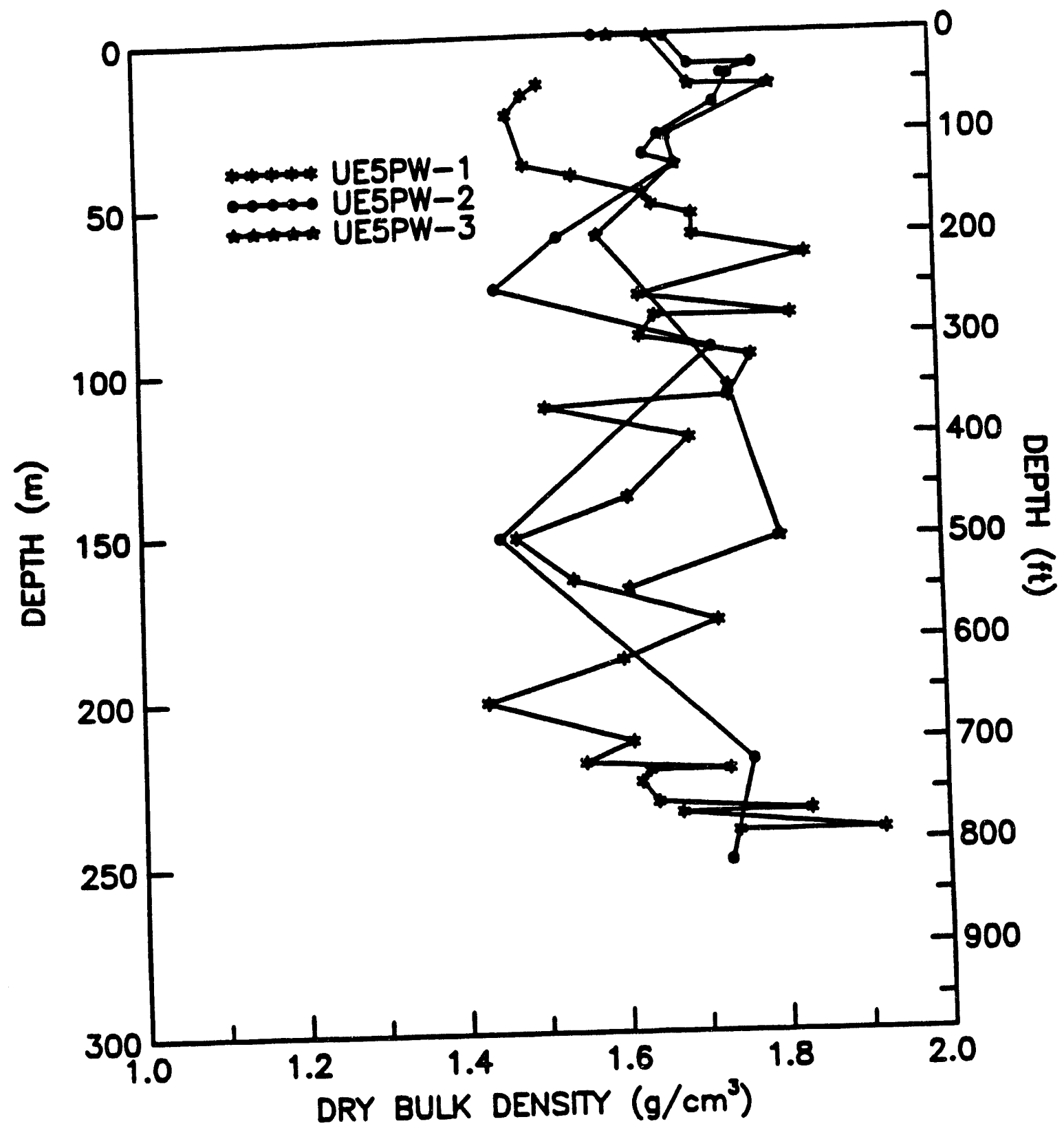

Figure 3.7 Depth profiles of dry bulk density for core samples from the Pilot Wells. 


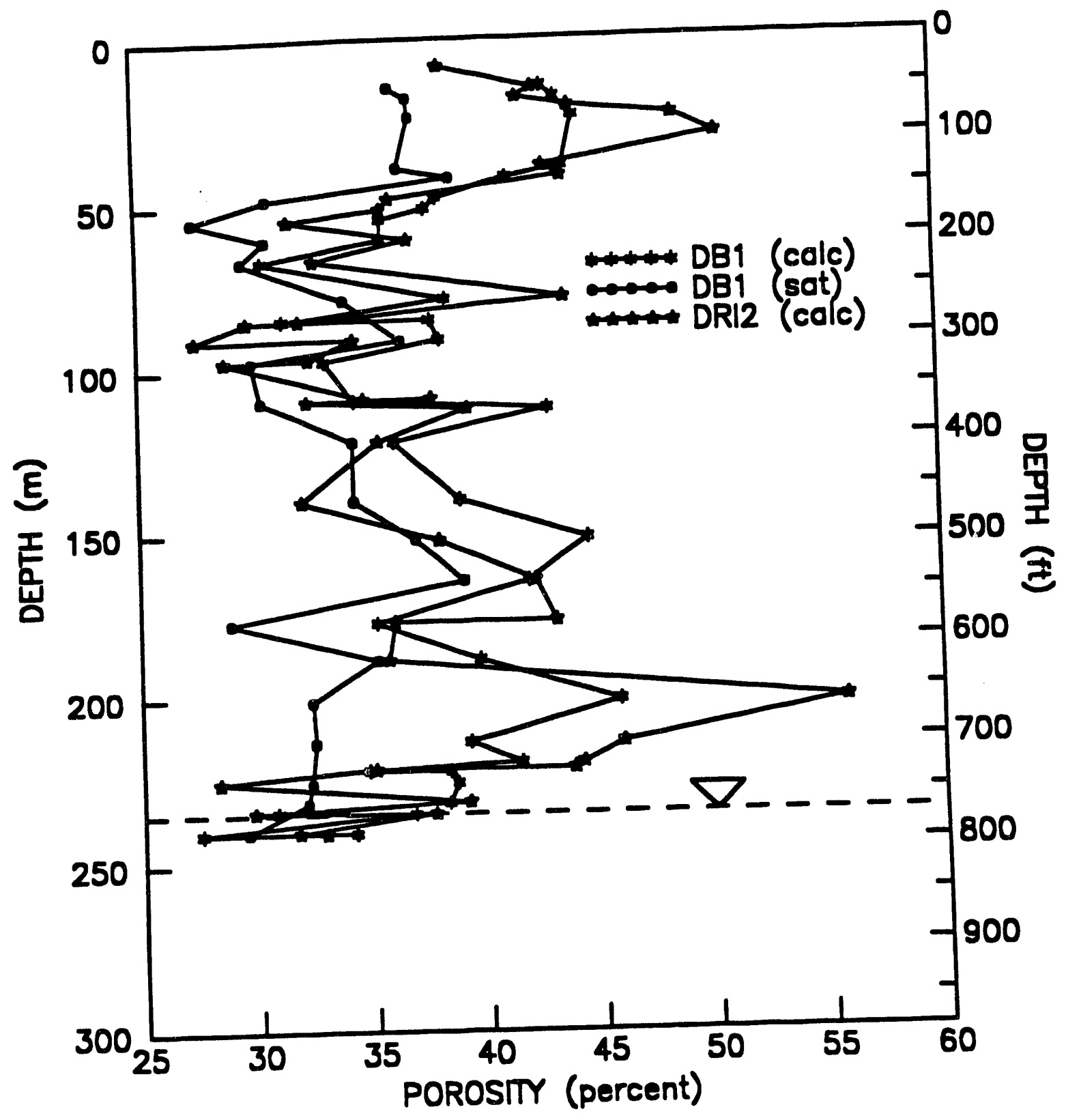

Figure 3.8 Depth profiles of calculated (calc) and water saturated (sat) porosity for core samples from UESPW-1. 


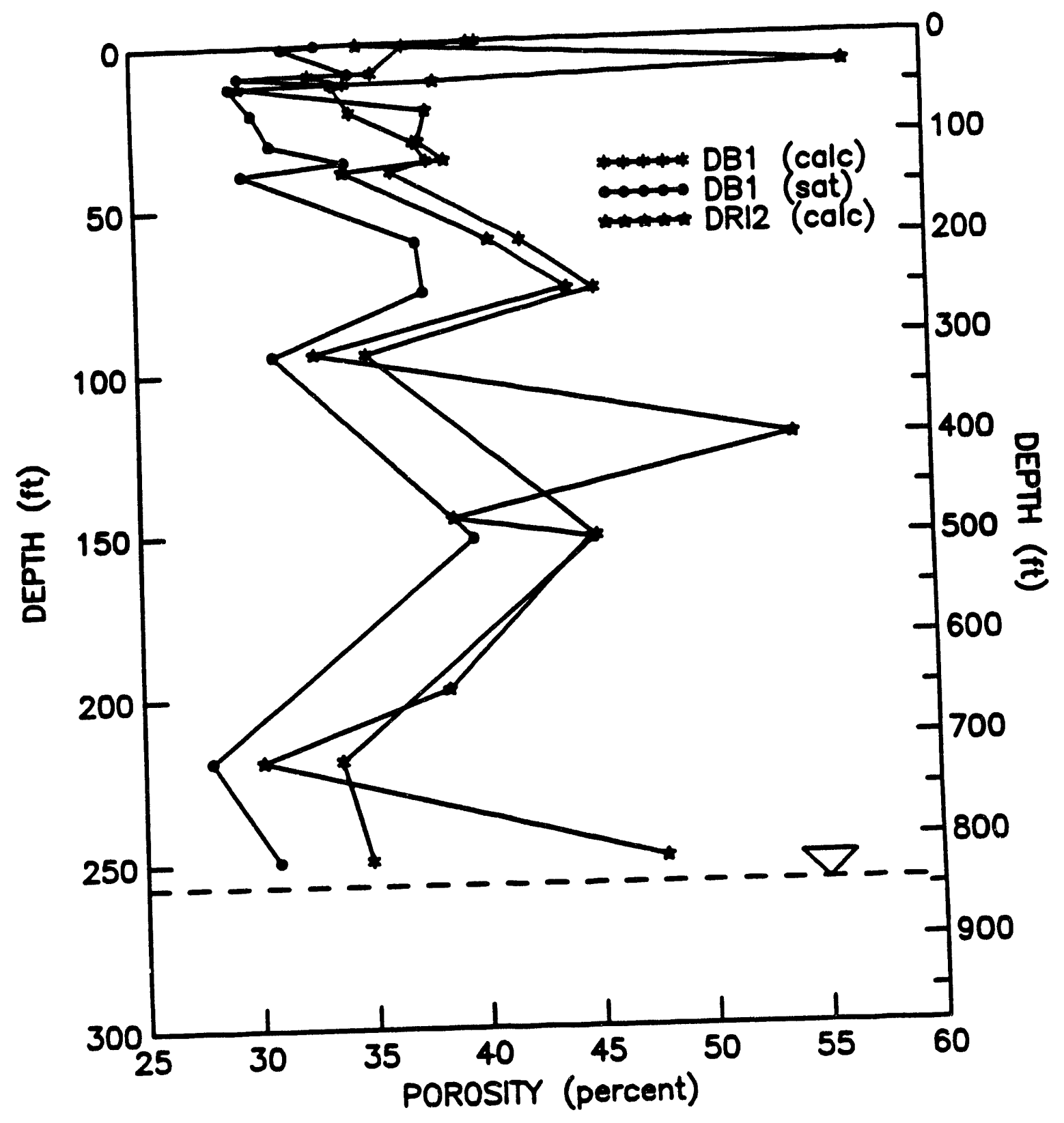

Figure 3.9 Depth profiles of calculated (calc) and water saturated (sat) porosity for core samples from UESPW-2. 


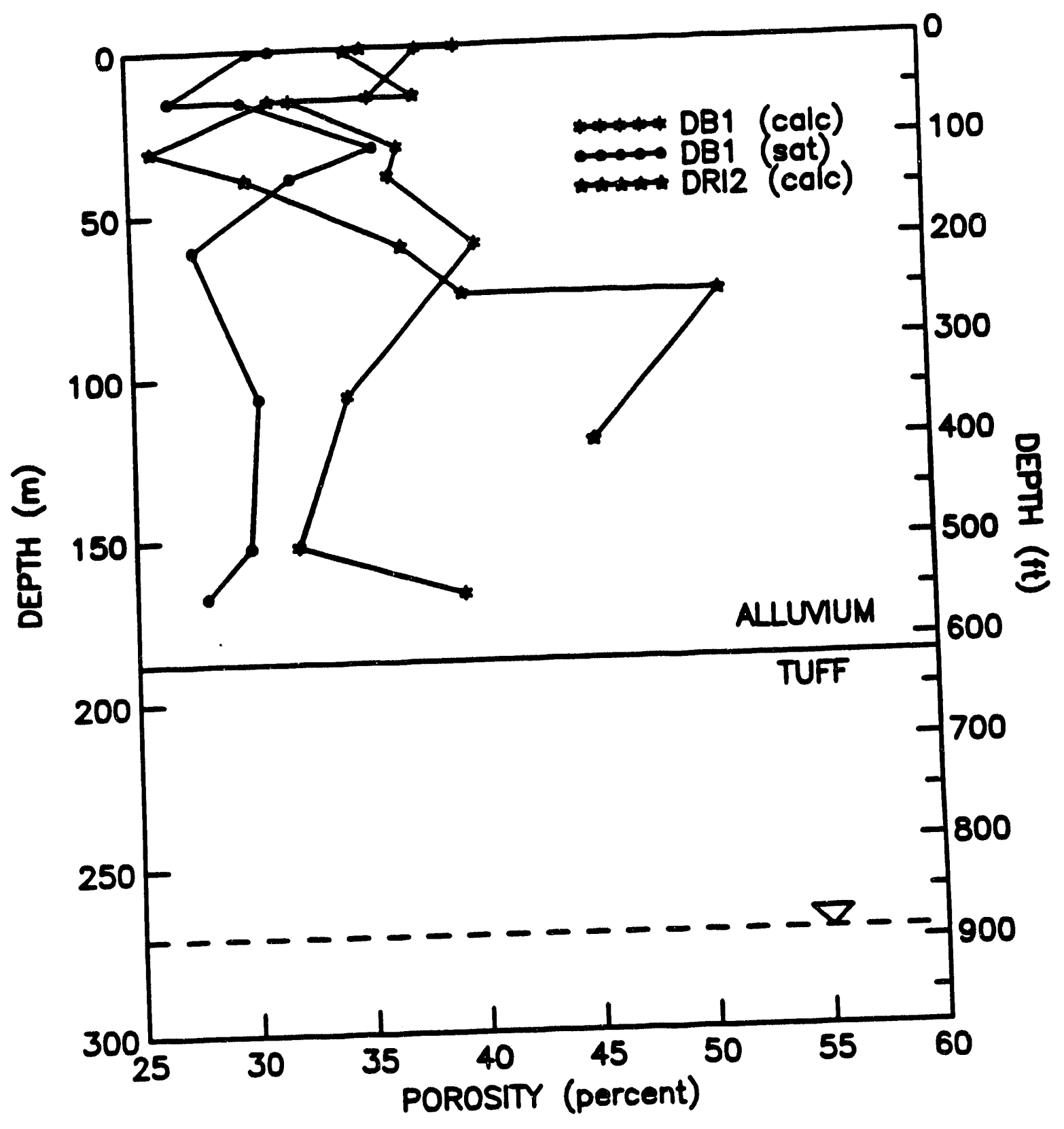

Figure 3.10 Depth profiles of calculated (calc) and water saturatod (sat) porosity for core samples from UESPW-3. 
The mean bulk density and calculated porosity of three partially welded tuff core samples are $1.99 \mathrm{~g} / \mathrm{cm}^{3}\left(124 \mathrm{lb} / \mathrm{ft}^{3}\right)$ and 22.40 percent, respectively (Table 3.4). These values fall into the range of values found for the same parameters on other partially welded tuff core samples from the NTS (Fernald et al., 1965).

\subsection{Hydrologic Properties}

Hydrologic properties are required, together with hydrologic conditions, to estimate rates of water movement and potential travel times. Hydrologic property measurements include saturated hydraulic conductivities and moisture retention curves. Unsaturated hydraulic conductivities were calculated from the above mentioned parameters in this study. Unsaturated hydraulic conductivities are very difficult, if not impossible, to measure in the laboratory at the very dry in situ water contents (Section 3.4.1) found in the vadose zone beneath the Area 5 RWMS.

\subsubsection{Saturated Hydraulic Conductivity}

Saturated hydraulic conductivity measurements, like dry bulk densities, were conducted on one 76.2-mm (3-in) long core segment from each alluvial core run in each Pilot Well, and on 25.4- $\mathrm{mm}(1-\mathrm{in})$ by $25.4-\mathrm{mm}$ plug subsamples from the UESPW-3 tuff formation. Saturated hydraulic conductivity profiles for the three Pilot Wells are presented in Figure 3.11, descriptive statistics are summarized in Table 3.3 (possible outliers were retained in computation of the descriptive statistics), and tabular data are listed in Appendix E.2. These data show that hydraulic conductivities range from $1.4 \times 10^{-6}$ to $5.8 \times 10^{-3} \mathrm{~cm} / \mathrm{s}(0.002$ to $8.2 \mathrm{in} / \mathrm{hr}$ ) for all Pilot Wells, with mean values for each Pilot Well ranging between $5.7 \times 10^{-1}$ to $1.1 \times 10^{-3} \mathrm{~cm} / \mathrm{s}(0.81$ to $1.6 \mathrm{in} / \mathrm{hr})$. There are no obvious trends as a function of depth, and these values are typical of silty sand alluvial deposits (Freeze and Cherry, 1979).

Statistical analyses have indicated hydraulic conductivity might be lognormally distributed (these analyses will be presented in a peer-reviewed joumal). A case could be made for presenting the geometric means and standard deviations, rather than the arithmetic means and standard deviations. Means and standard deviations were used to facilitate comparison with other values reported in the literature.

\subsubsection{Moisture Retention Relations}

Following saturated hydraulic conductivity measurements, core samples were subjected to moisture retention measurements. These measurements (curves) for UE5PW-1, UE5PW-2, and UE5PW-3 are presented in graphical form in Figures 3.12, 3.13, and 3.14, respectively; 


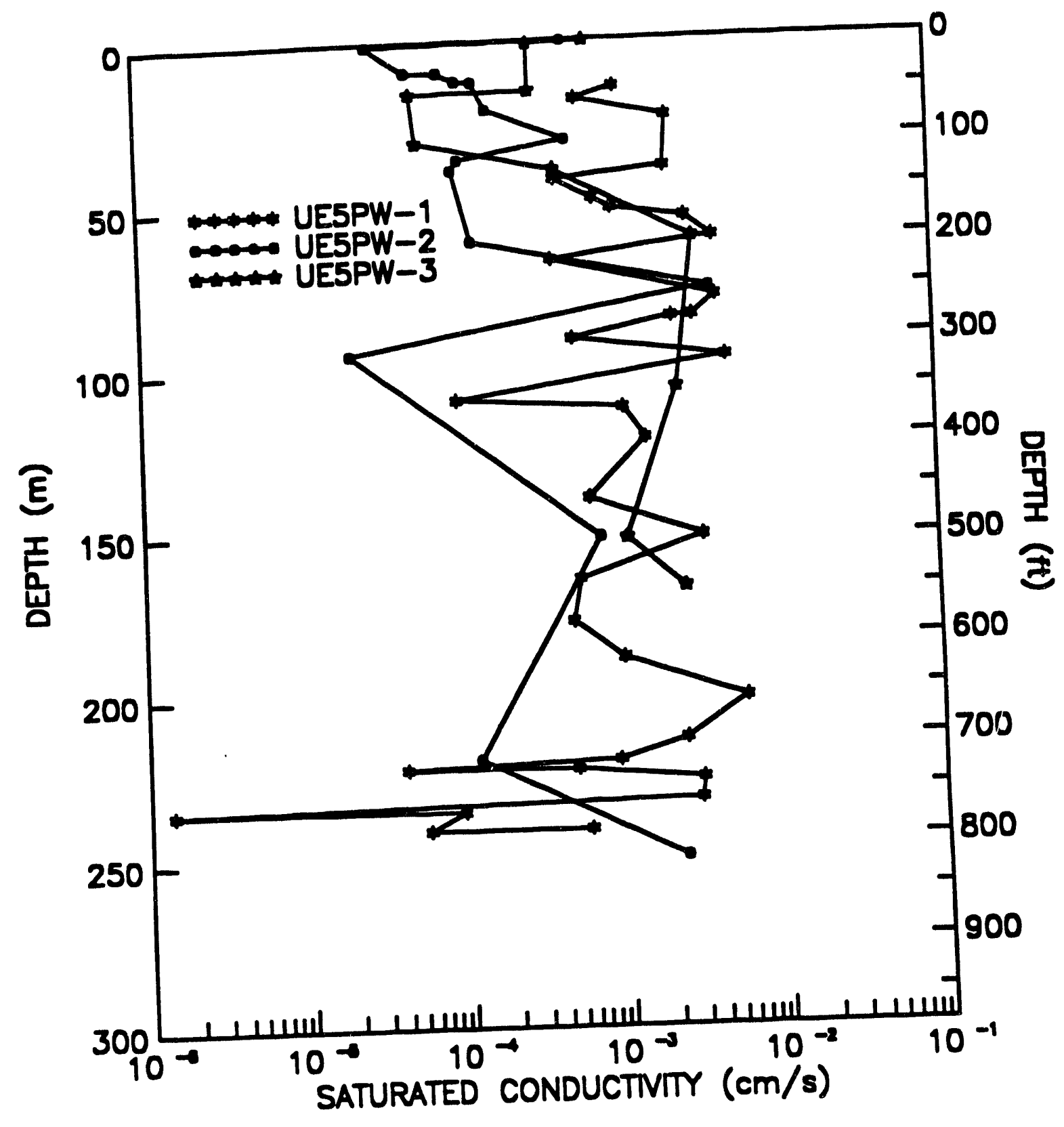

Figure 3.11 Depth profiles of saturated hydraulic conductivity for core samples from the Pilot Wells. 


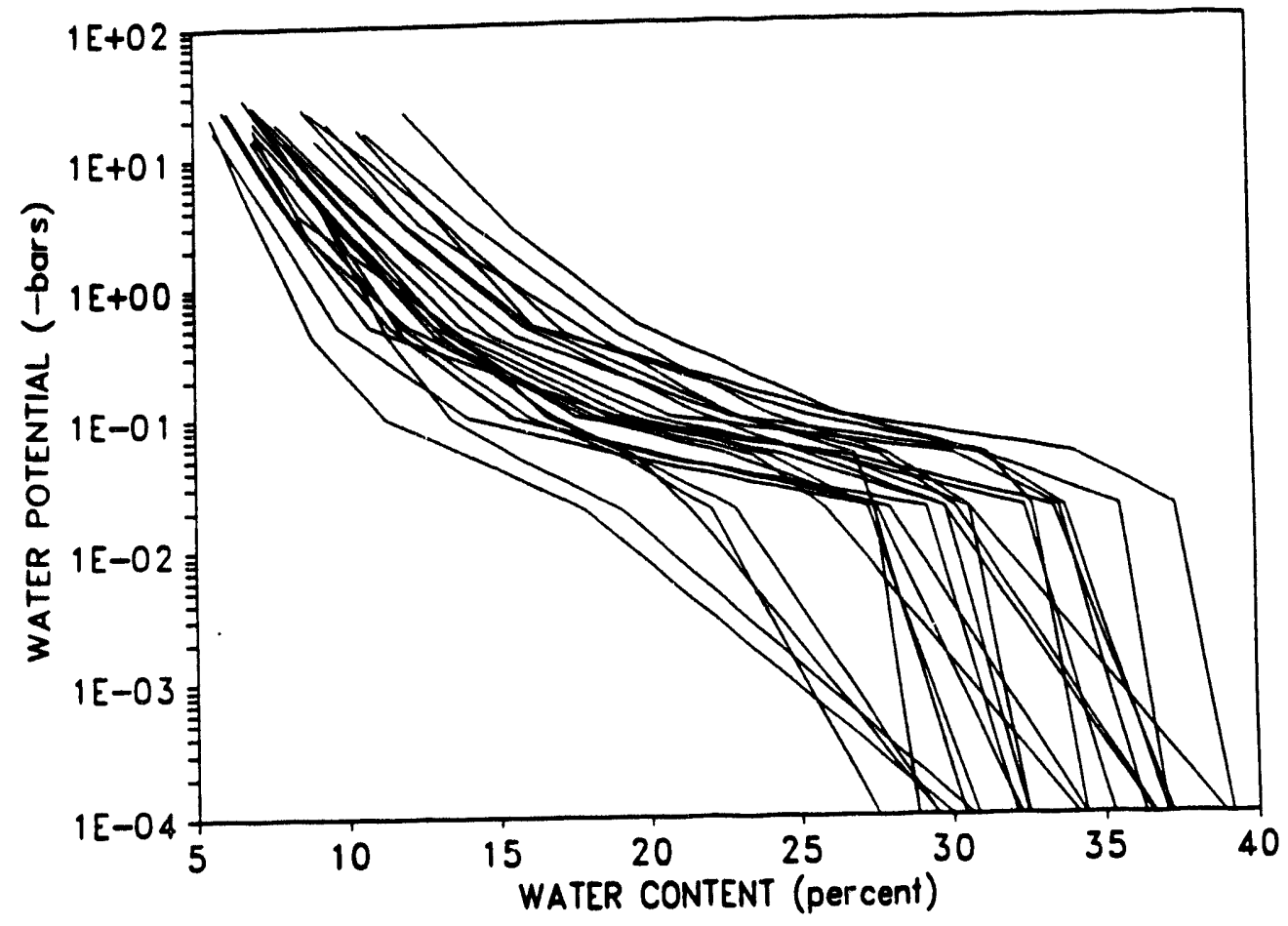

Figure 3.12 Composite moisture retention data for core samples from UE5PW-1. 


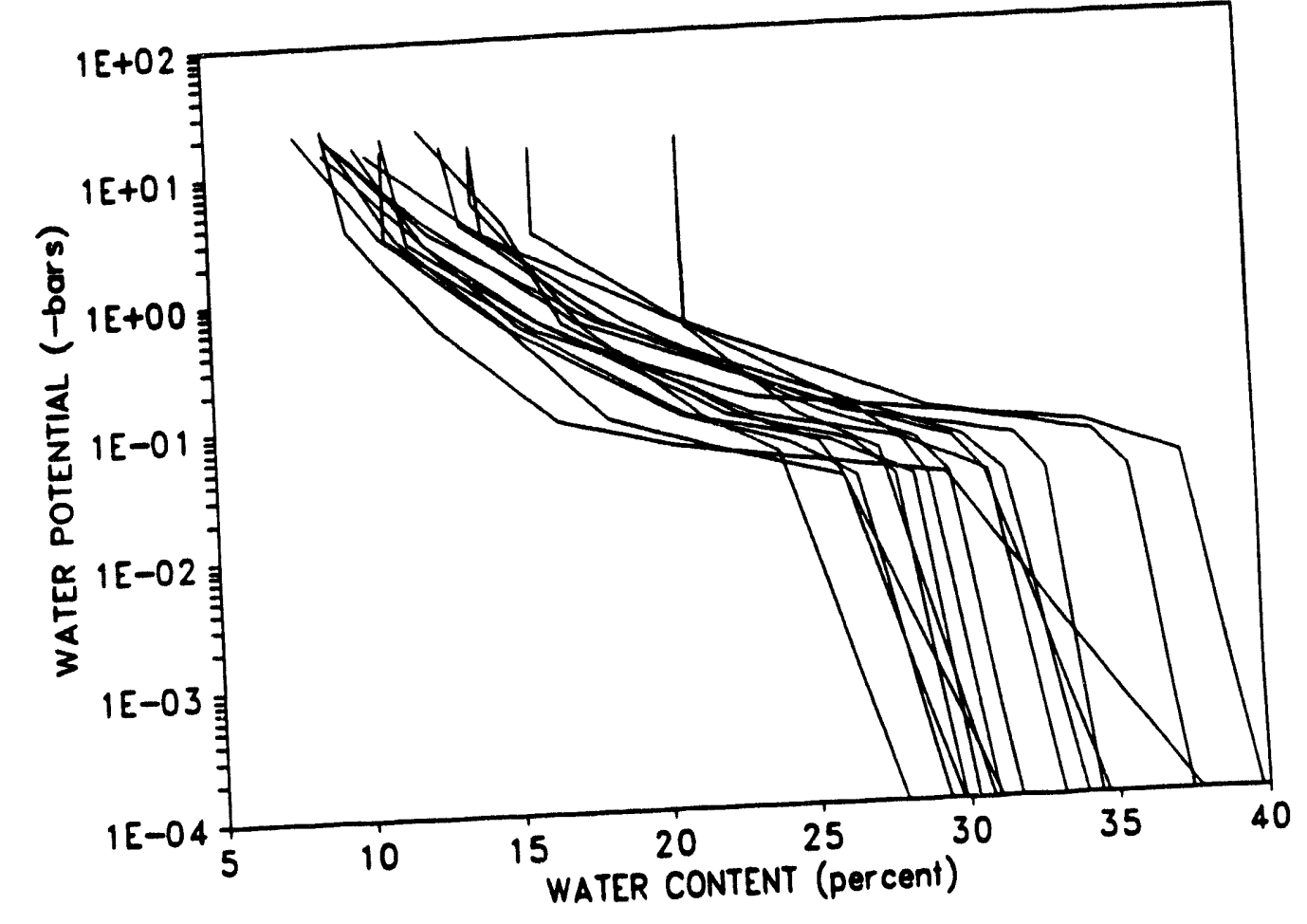

Figure 3.13 Composite moisture retention data for core samples from UESPW-2. 


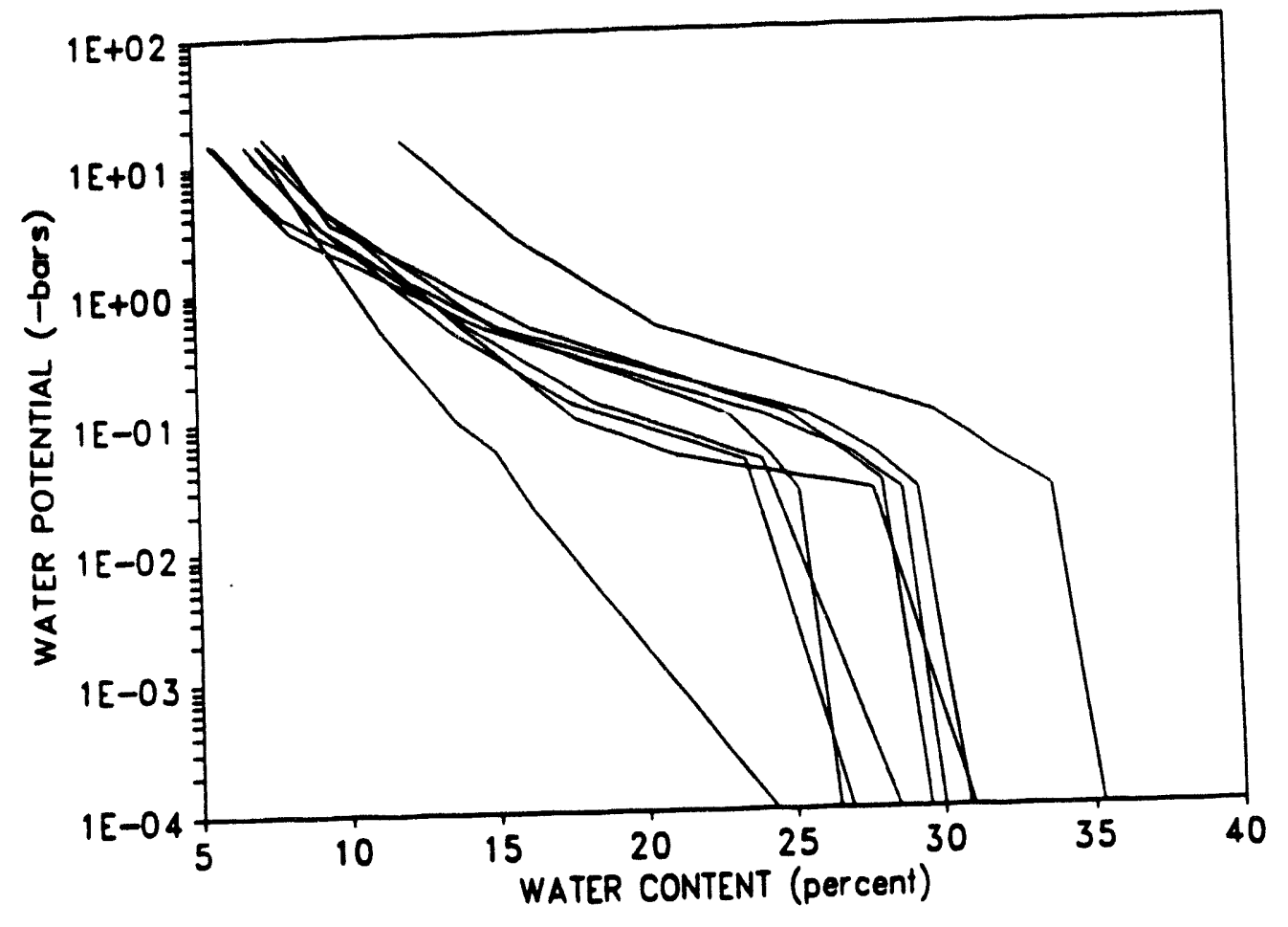

Figure 3.14 Composite moisture retention data for core samples from UESPW-3. 
tabular data are listed in Appendices E.2.7 to E.2.9. Core interval depths for each curve are not identified in these plots. The general shape of these moisture retention curves is (without exception) typical of coarse-grained deposits (Hillel, 1980).

Moisture retention data were fit to the van Genuchten $(1978,1980)$ parameterization of the water retention curve described by:

$$
\theta=\theta_{1}+\left(\theta_{1}-\theta_{1}\right)\left[1+(-\alpha h)^{\theta}\right]-
$$

where $\theta$ is volumetric water content $\left(\mathrm{cm}^{3} / \mathrm{cm}^{3}\right), \theta$, is the saturated volumetric water content, $\theta_{r}$ is the residual volumetric water content, $h$ is matric potential $(\mathrm{cm}), \alpha\left(\mathrm{cm}^{-1}\right)$, and $n$ (dimensionless) are curve fitting parameters, and $m$ is $(1-1 / n)$.

A ronlinear least squares computer code is used to calculate the curve-fitting parameters $\alpha$ and $n$, and residual saturation, $\theta_{r}$. These parameters are tabulated in Appendix E.2.10 for all Pilot Well core samples, and summary descriptive statistics are given in Table 3.6. There is some evidence $\alpha$ is lognormally distributed, indicating that the geometric mean and standard deviation would be more appropriate data summaries than the arithmetic mean and standard deviation. The latter were reported to facilitate comparison with other values reported in the literature. Observed values of $\alpha$ are consistent with values calculated for a number of coarse-grained materials (van Genuchten, 1978).

\subsubsection{Unsaturated Hydraulic Conductivity}

Unsaturated hydraulic conductivity, $\mathrm{K}(\mathrm{S})$, of core samples are generally calculated from moisture retention data and saturated hydraulic conductivity rather than being experimentally measured. This is primarily because experimental measurements, especially at low water contents, are extremely difficult, if not impossible to obtain. The equation used to calculate $K(S)$ in this program (van Genuchten, 1978, 1980) is derived by substituting the van Genuchten moisture retention curve-fitting parameters into the Mualem (1976) model of unsaturated hydraulic conductivity to obtain the following:

$$
K(S)=K_{s} S^{* / 2}\left[1-\left(1-S^{1 / \infty}\right)\right]^{2}
$$

where $K_{1}$ is the saturated hydraulic conductivity, $m$ is as in the van Genuchten water retention curve, and $S$ is effective saturation as defined by:

$$
S=\left(\theta-\theta_{\mathrm{r}}\right)\left(\theta_{\mathrm{s}}-\theta_{\mathrm{r}}\right)^{-1}
$$


Table 3.6 Summary of descriptive statistics of moisture retention curves for core samples from the Pilot Wells. ( $s$ is the number of samples, CV is coefficient of variation).

\begin{tabular}{llllll}
\hline Borehole & Statistic & $\begin{array}{c}\theta_{\mathrm{r}} \\
\left(\mathrm{cm}^{3} / \mathrm{cm}^{3}\right)\end{array}$ & $\begin{array}{c}\theta_{\mathrm{a}} \\
\left(\mathrm{cm}^{3} / \mathrm{cm}^{3}\right)\end{array}$ & $\begin{array}{c}\alpha \\
\left(\mathrm{cm}^{-1}\right)\end{array}$ & $n$ \\
\hline UESPW-1 & Minimum & 0.00 & 0.275 & 0.010 & 1.16 \\
$(\mathrm{~s}=24)$ & Maximum & 0.108 & 0.392 & 0.037 & 1.82 \\
& Mean & 0.061 & 0.335 & 0.090 & 1.49 \\
& Standard Deviation & 0.030 & 0.034 & 0.10 & 0.22 \\
& CV (percent) & 49.8 & 10.1 & 114.5 & 14.6 \\
UJE5PW-2 & Minimum & 0.00 & 0.279 & 0.010 & 1.16 \\
(s = 16) & Maximum & 0.105 & 0.398 & 0.060 & 1.97 \\
& Mean & 0.052 & 0.327 & 0.020 & 1.39 \\
& Standard Deviation & 0.031 & 0.034 & 0.010 & 0.20 \\
& CV (percent) & 59.8 & 10.4 & 52.0 & 14.6 \\
UJESPW-3 & Minimum & 0.017 & 0.269 & 0.010 & 1.14 \\
(s=9) & Maximum & 0.086 & 0.359 & 2.31 & 1.48 \\
& Mean & 0.045 & 0.303 & 0.028 & 1.38 \\
& Standard Deviation & 0.022 & 0.027 & 0.76 & 0.11 \\
& CV (percent) & 48.7 & 9.0 & 276.9 & 7.8 \\
\hline
\end{tabular}


The resulting $K(S)$ data, which have been converted to $K(\theta)$ data through Eq. 2, are illustrated for UESPW-1, UESPW-2, and UESPW-3 in Figures 3.15, 3.16, and 3.17, respectively.

These plots illustrate that unsaturated hydraulic conductivities decrease rapidly with decreasing water contents. At the low in situ formation water contents (Section 3.4.1) the unsaturated hydraulic conductivities are many orders of magnitude less than saturated hydraulic conductivities.

\subsection{Hydrologic Conditions}

Hydrologic conditions are parameters that vary over time. These include water content and water potential, where the latter is dependent on the former. The gradient of water potential values (i.e., the difference in value between two points divided by the distance separating these points) is one of the primary forces which drive the movement of liquid water.

\subsubsection{Water Content}

Water content on a weight basis (gravimetric water content) was determined for both drill cuttings and core samples. Water content on a volume basis (volumetric water content) was determined only for core samples. These data are summarized in tabular form in Appendix E.2, and descriptive statistics are presented in Tables 3.3 and 3.4 for alluvium and tuff, respectively. Gravimetric water content for both core and drill cuttings samples from the alluvium are plotted vs. depth for UESPW-1, UESPW-2, and UESPW-3 in Figures 3.18, 3.19 , and 3.20 , respectively.

The mean gravimetric water content of alluvial drill cuttings samples were generally several percent lower than the gravimetric water content of core samples. This is because the drill cuttings samples were subjected to drying by the air drilling fluid as they were lifted out of the borehole. The limited data available comparing tuff core and drill cuttings samples suggest that this drying occurs even more when drilling the tuff formation. Less drying occurred with coarse cuttings fragments than with the mixture of fine and coarse fragments that came directly out of the collection separator. The smaller surface area-to-volume ratio of coarse fragments is expected to be responsible for these effects. Moreover, based on only three core samples from one core run, the water content of the tuff is higher than overlying alluvial core samples. However, these water content differences are consistent with neutron geophysical logs described in Section 4.3.2.

A comparison of the alluvial volumetric water content profiles from all three Pilot Wells (Figure 3.21) illustrates that water content values were remarkably low and constant throughout the entire zone of the unsaturated alluvium. The only noticeable trend is a possible slight increase in water content from the ground surface to a depth of approximately 


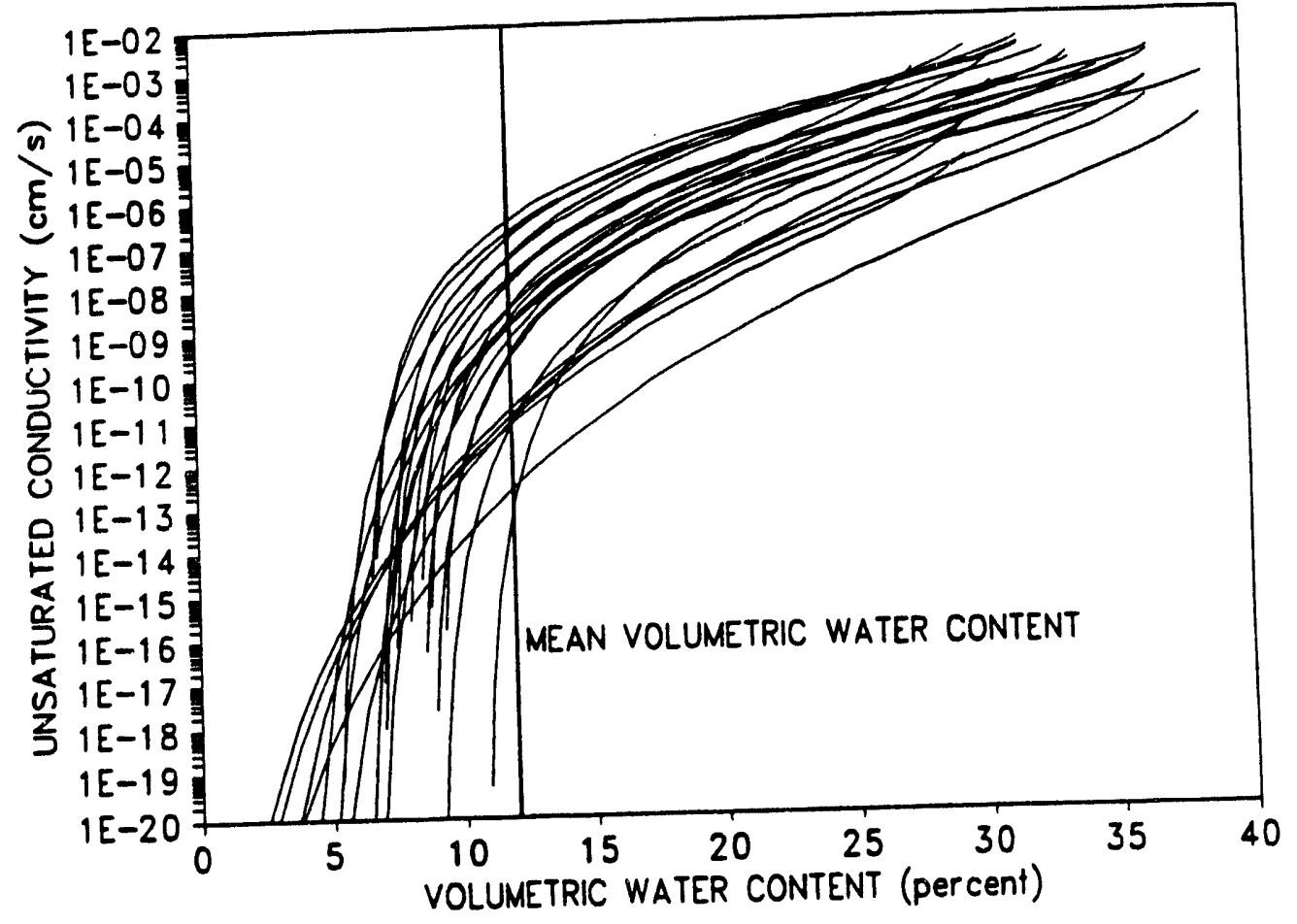

Figure 3.15 Fitted unsaturated hydraulic conductivity functions for core samples from UE5PW-1. 


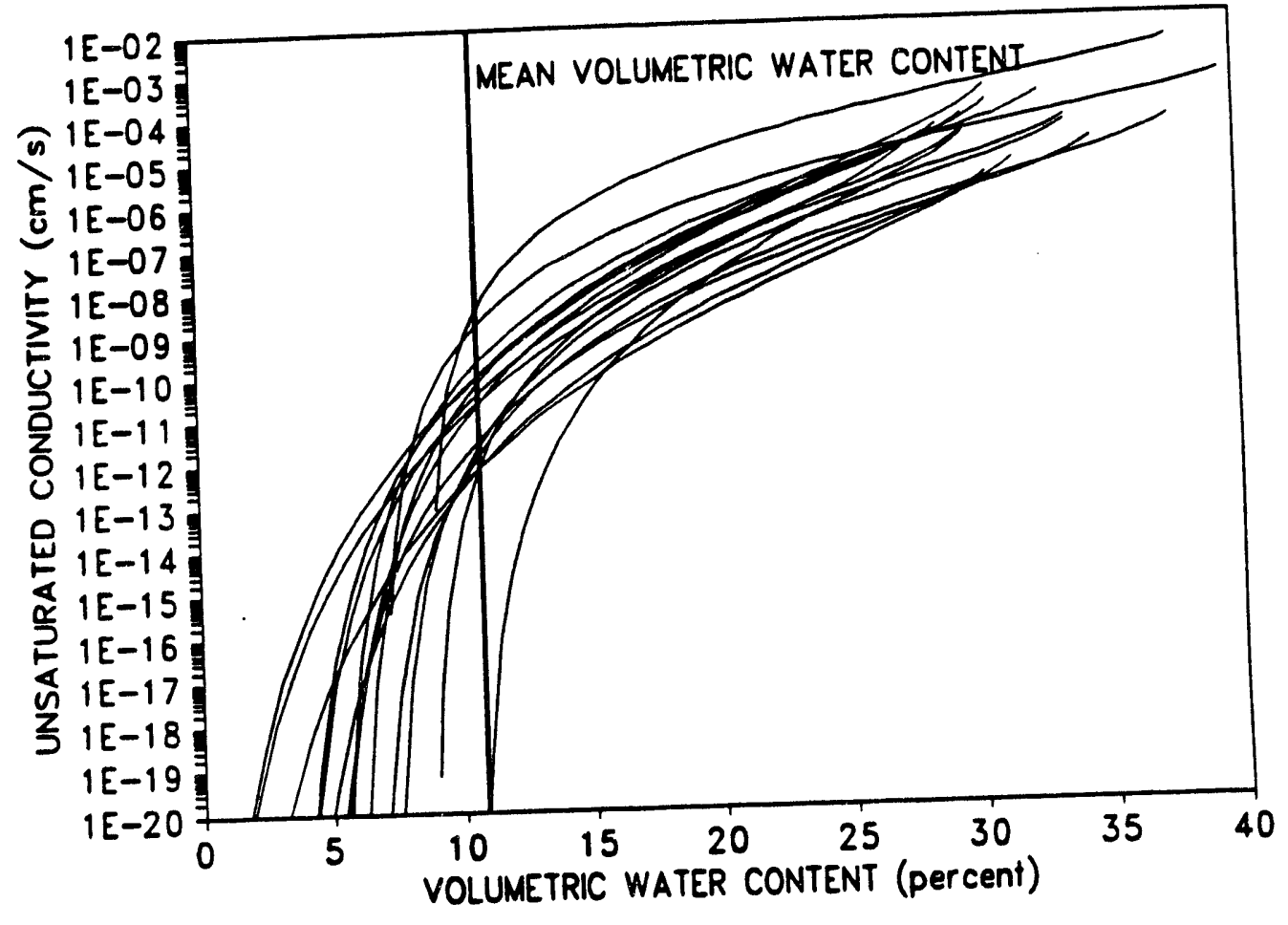

Figure 3.16 Fitted unsaturated hydraulic conductivity functions for core samples from UE5PW-2. 


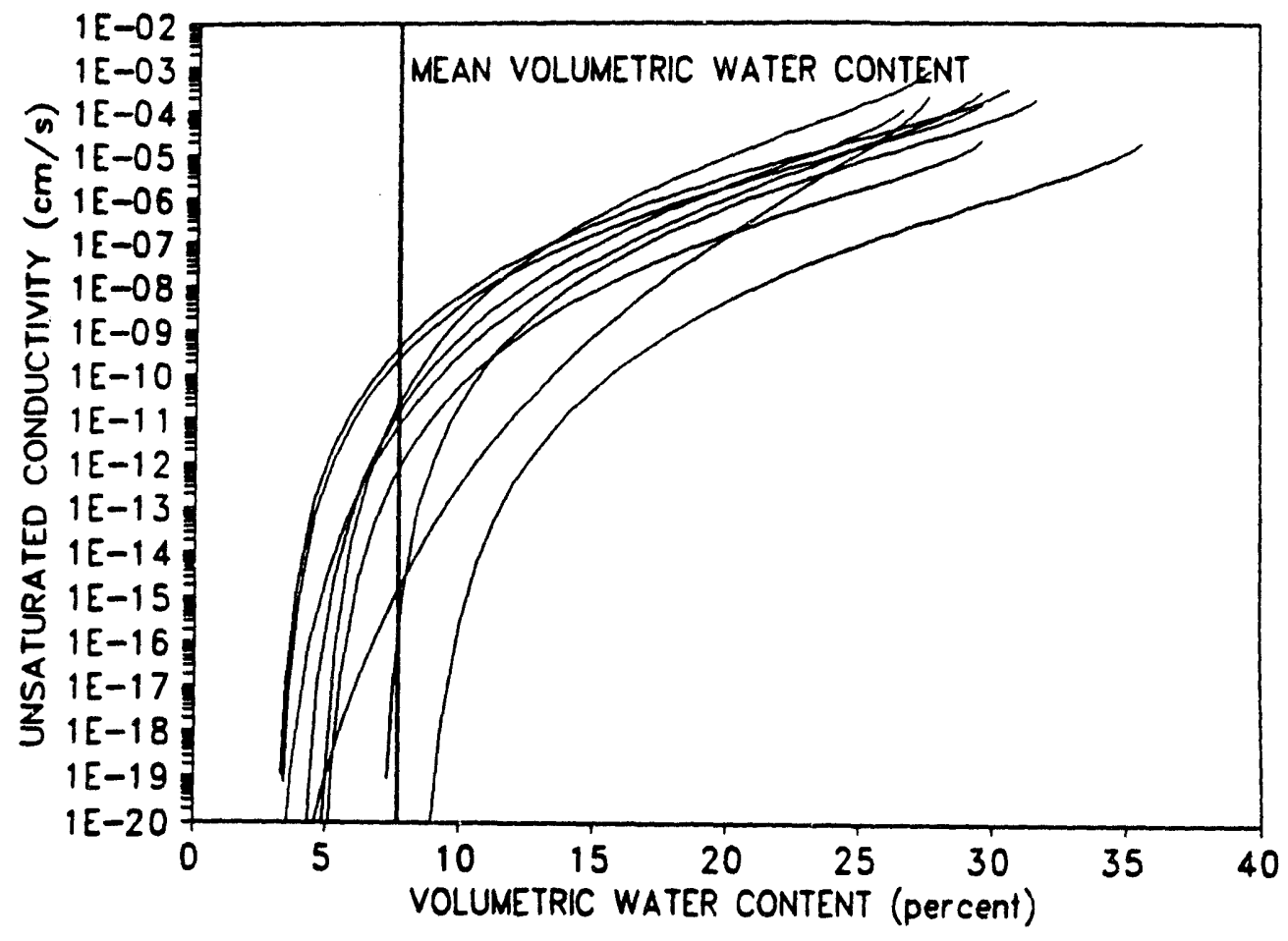

Figure 3.17 Fitted unsaturated hydraulic conductivity functions for core samples from UE5PW-3. 


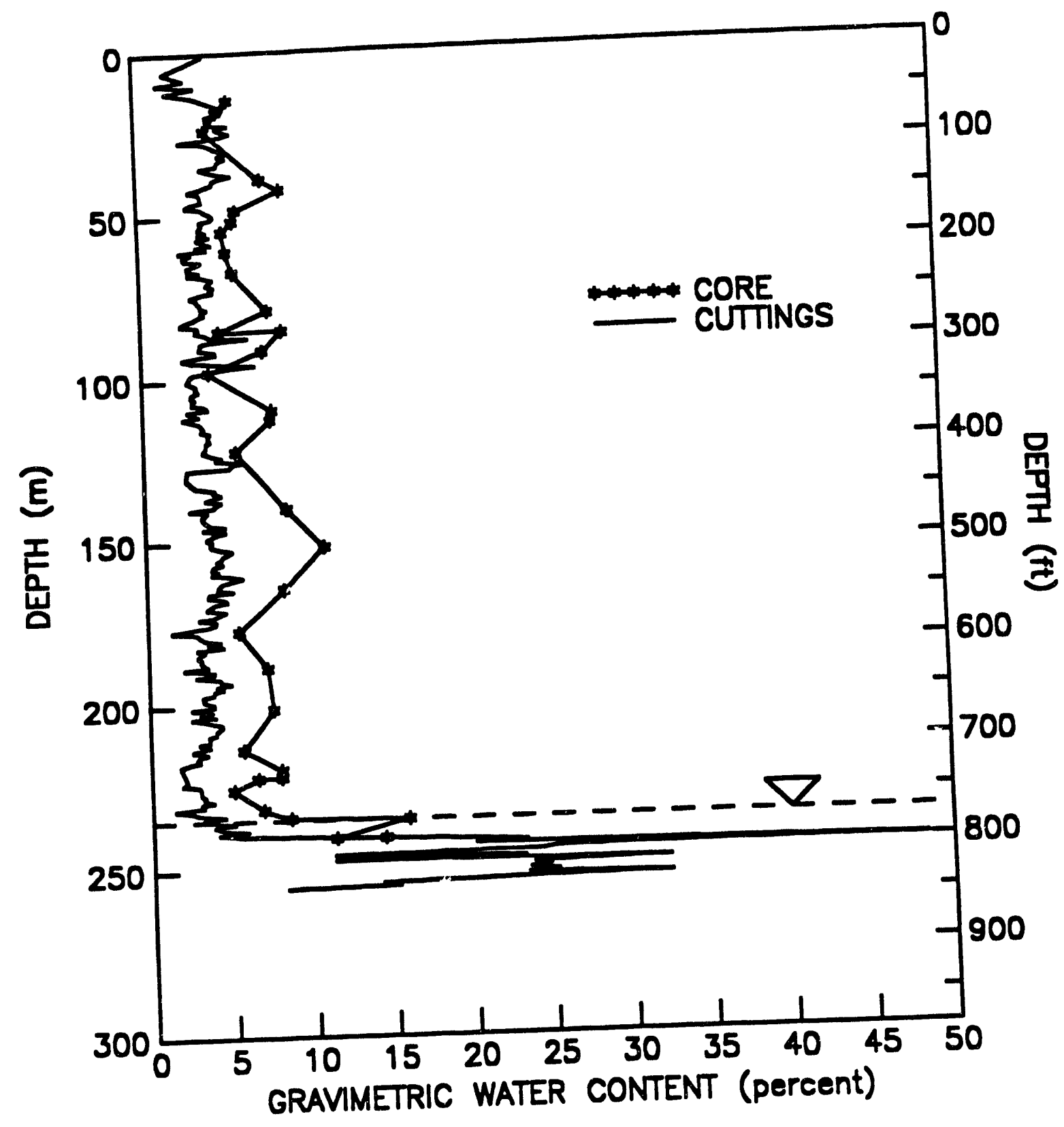

Figure 3.18 Depth profiles of gravimetric water content for core and drill cuttings samples from UESPW-1. 


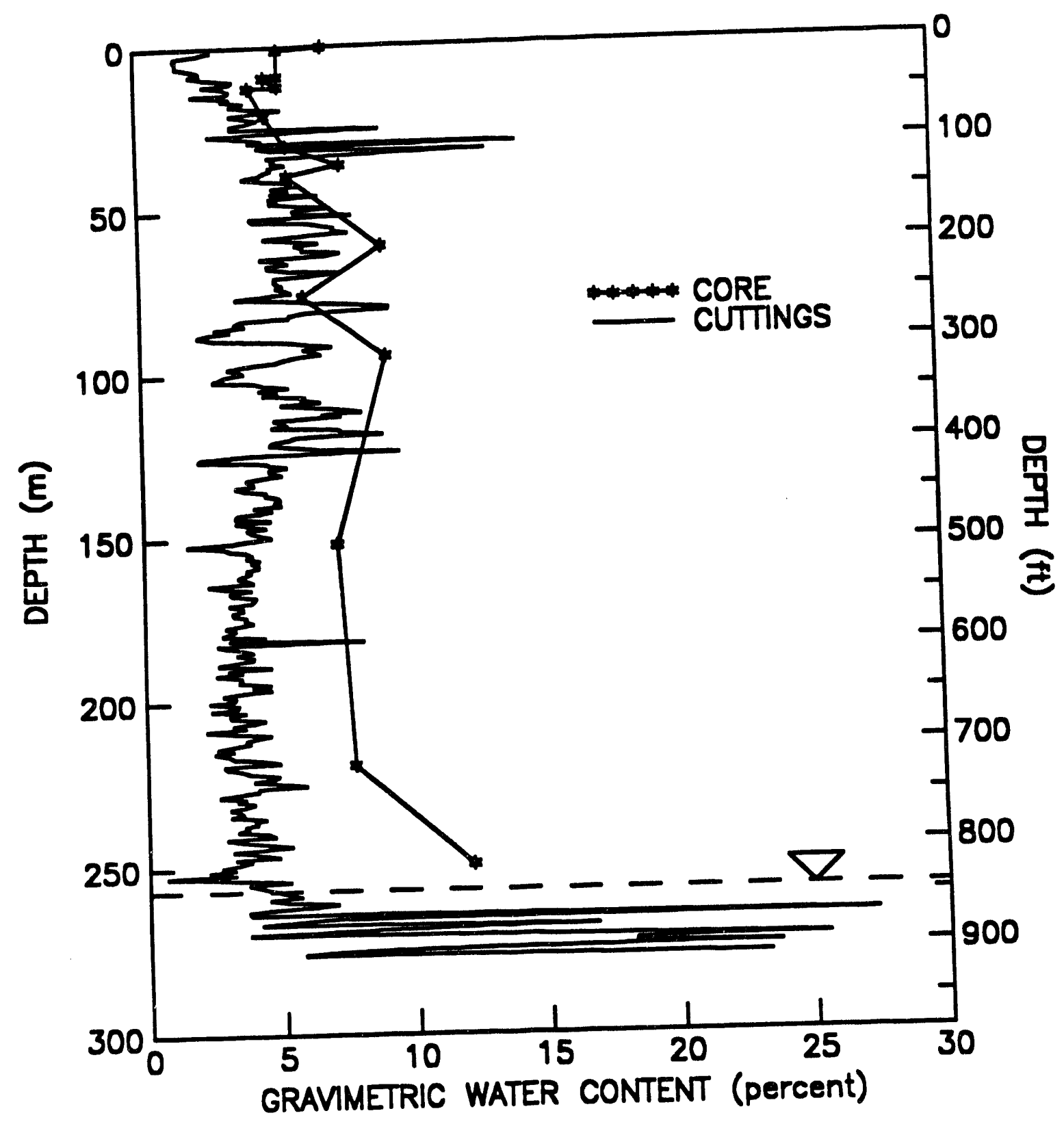

Figure 3.19 Depth profiles of gravimetric water content for core and drill cuttings samples from UESPW-2. 


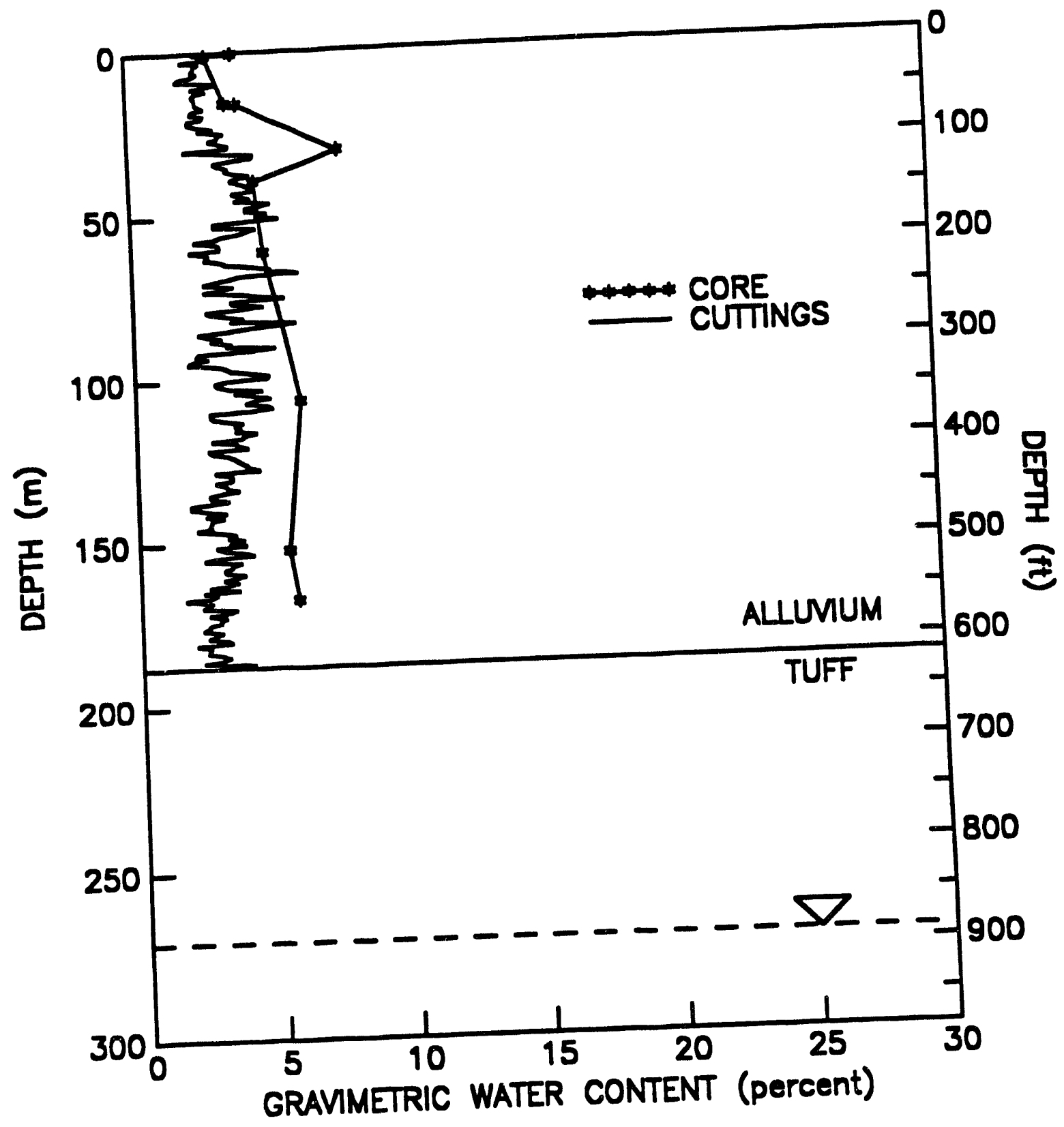

Figure 3.20 Depth profiles of water content for core and drill cuttings samples from UE5PW-3. 


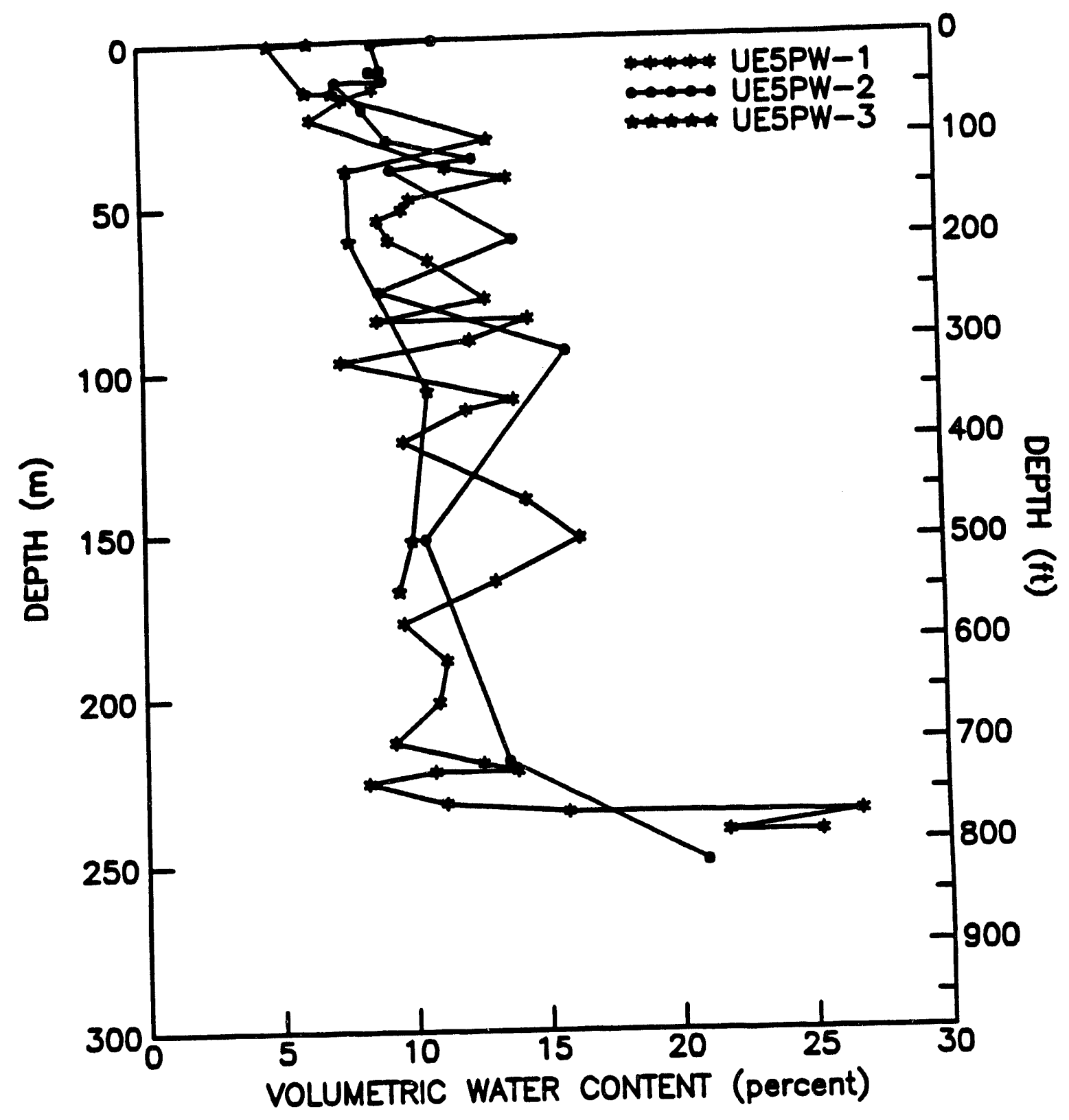

Figure 3.21 Depth profiles of volumetric water content for core samples from the Pilot Wells. 
calculated residual water contents (Table 3.6). This suggests that little, if any, water is presently draining from the system. Both the unsaturated hydraulic conductivity data discussed previously (Section 3.3.3) and the water potential data discussed below (Section 3.4.2) support this picture of the system.

\subsubsection{Water Potential}

Depth profiles of water potential data from geologic samples are summarized in tabular form in Appendix E.2, and descriptive statistics are given in Table 3.3 and 3.4. Water potential measurements were made on nearly every alluvial core sample, on two tuff core samples from UESPW-3, and on coarse drill cuttings fragments of tuff to supplement data from tuff core samples. Coarse drill cuttings were separated from composite drill cuttings obtained from the cyclone separator by sieving on a No. 4 mesh screen. It was thought that a smaller surface area-to-volume ratio of these coarse drill cuttings compared to a composite sample of drill cuttings would make them less susceptible to disturbance (e.g., drying) by the air drilling fluid.

It was expected that in situ water potentials would be nearly equal in alluvial and underlying tuff formations penetrated in UESPW-3, assuming quasi steady-state conditions exist as suggested in the previous section. This is true for alluvium and tuff core samples, however, the water potentials of coarse tuff fragments (sieved drill cuttings) were generally more than an order of magnitude less than alluvium core values. This suggests that water potentials of drill cuttings samples from the tuff were not representative of in situ conditions. Because of the highly nonlinear relationship between water potential and water content (Figures 3.12, 3.13, and 3.14), a small decrease in water content of coarse tuff drill cuttings resulting from the drying effects of the air drilling fluids could easily be responsible for the large order of magnitude decreases in water potential.

Water potential depth profile data (distance is positive downwards), shown in Figure 3.22, show a positive gradient (upward flow) to at least a depth of $30.5 \mathrm{~m}$ (100 ft) in each Pilot Well. These data, coupled with unsaturated hydraulic conductivity, indicate that liquid water is probably moving upward very slowly in this region. The water potential gradient is the principal driving force moving liquid water, because other potential gradients affecting water movement are small compared to the water potential gradient. For example, the water potential gradient near the ground surface is very large, the osmotic component of this potential has a value near zero based on dissolved salt data, and the gravitational potential gradient is equal to unity (1.0) by definition. The hydraulic potential gradient, which is the total driving force, can be defined as the gravitational potential gradient plus the water potential gradient minus the osmotic potential gradient.

Environmental tracer data from the Pilot Wells suggest that the upward movement of liquid water, indicated by water potential measurements, result from evaporation, at least in the upper $30.5 \mathrm{~m}$. These data will be presented in Section 3.5 . 


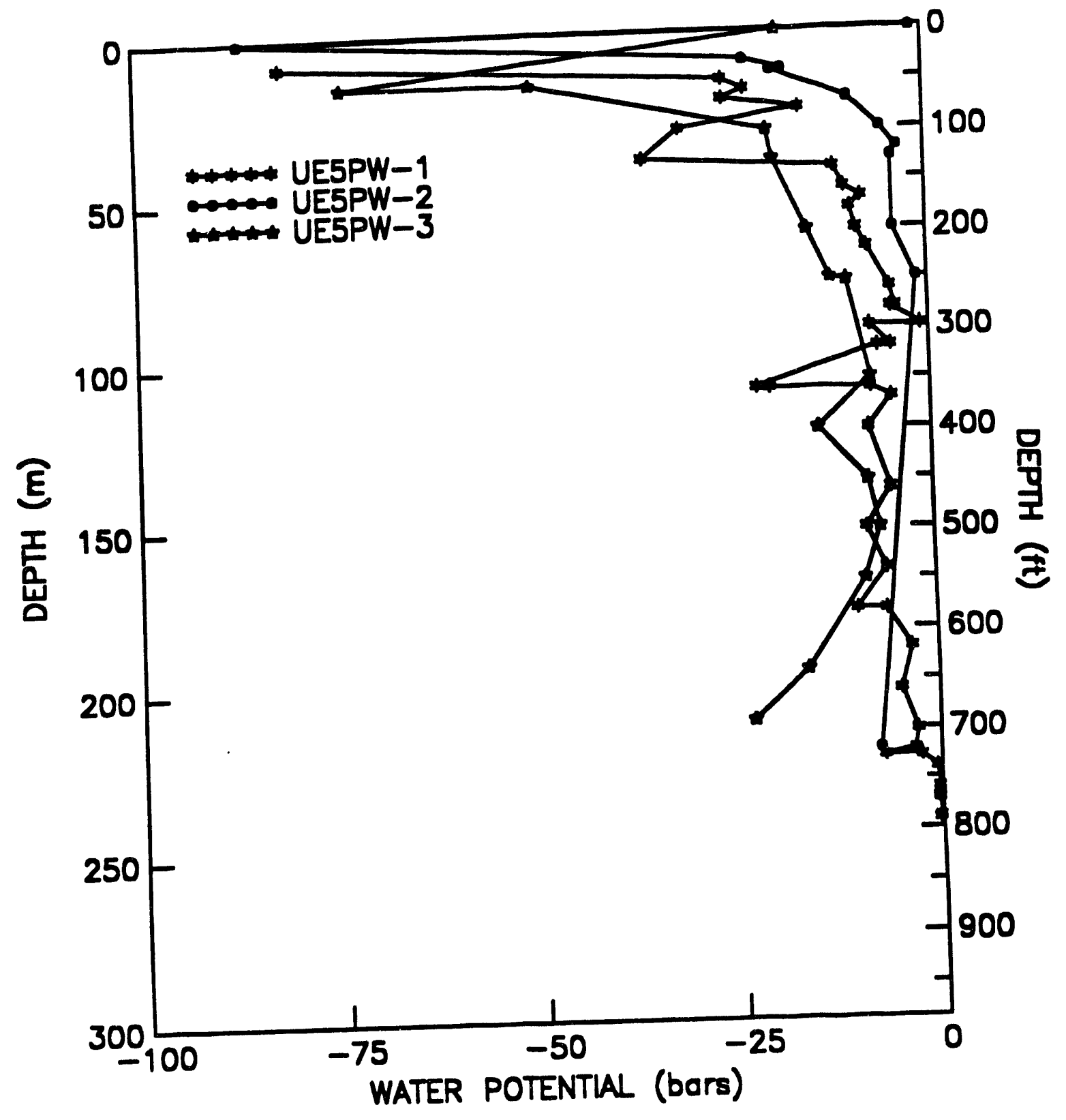

Figure 3.22 Depth profiles of water potential for core samples from the Pilot Wells. 
At greater depths the water potential gradient appears to be nearly zero. This is illustrated in Figure 3.22 and is supported by descriptive statistics for alluvium beneath $45.7 \mathrm{~m}$ (150 ft). Based on these data and unsaturated hydraulic conductivity data, it is possible to make an order of magnitude calculation of the rate of liquid water movement. The nearly zero water potential gradient at depth implies that the unit gravitational gradient is the main driver of liquid water movement and is equal to the hydraulic gradient. It follows then (from Darcy's law assuming one-dimensional flow) that the flux of water is equal to the unsaturated hydraulic conductivity at the water content of interest. Figure 3.15 for example, at the mean water content of 11.2 percent in UESPW-1, the unsaturated hydraulic conductivity (also water flux $)$ is in all cases below $1 \times 10^{-7} \mathrm{~cm} / \mathrm{s}\left(1 \times 10^{-4} \mathrm{in} / \mathrm{hr}\right)$, and for the median unsaturated hydraulic conductivity curve it is approximately $1 \times 10^{-9} \mathrm{~cm} / \mathrm{s}\left(1 \times 10^{-6} \mathrm{in} / \mathrm{hr}\right)$. Assuming a water-filled porosity of 10 percent, this average flux value is equivalent to a travel velocity ofapproximately $3 \times 10^{-3} \mathrm{~m} / \mathrm{yr}\left(1 \times 10^{-2} \mathrm{ft} / \mathrm{yr}\right)$. In other words, on the average it would take 1,000 yrs for water to travel $3 \mathrm{~m}$ (10 ft).

These "back of the envelope" calculations simply suggest that liquid water flow is not very important beneath the Area 5 RWMS, and hazardous constituents (e.g., most metals) that are dependent on water movement will be essentially immobile if the disposal unit design does not significantly disturb the natural hydrologic setting. At the same time, the very low water contents and liquid fluxes beneath the Area 5 RWMS imply that gas flow and transport are very important.

\subsection{Environmental Tracers}

Environmental tracers provide another method, independent of the hydraulic parameters mentioned above, for estimating water movement in the vadose zone, travel times, and recharge. The basic premise of this method is that infiltrating water (from precipitation and runoff) contains dissolved natural and man-made tracers that travel with the water as it moves into and through the vadose zone. The concentrations of these tracers were measured with depth, and the analysis of the profile data yields information concerning the history of water movement through the unsaturated zone. Further, it is assumed that formation materials do not contribute to the concentrations of these tracers. In the following sections, only general observations will be made concerning the tracer profile data.

\subsubsection{Chloride/Bromide Profiles}

Chloride and bromide ions can serve as tracers because their negative charge discourages sorption with negatively charged mineral surfaces at solution $\mathrm{pH}$ values commonly found in soils and alluvium. The chloride mass balance method for estimating recharge (Allison and Hughes, 1983) is based on the assumption that concentrations of chloride are relatively constant in precipitation, and as water evaporates from the soil leaving this ion behind, the concentration of chloride increase in the soil water. A mass balance approach using bromide has not been used, primarily because of the low concentrations of bromide in precipitation and the related absence of bromide concentration data. 
Chloride and bromide concentrations were measured on all drill cuttings and core samples. Tabular data are summarized in Appendix E.2. Descriptive statistics were calculated for chloride and bromide concentration data below $76.2,30.5$, and $121.9 \mathrm{~m}(250,100$, and $400 \mathrm{ft}$ ) in UESPW-1, UE5PW-2, and UESPW-3, respectively (Table 3.3). Beneath these depths the concentrations of chloride and bromide are very low and approximately constant.

Depth profiles of chloride concentrations (per unit dry weight of soil) for drill cuttings samples from all three Pilot Wells are illustrated in Figure 3.23, and similar profiles from core samples are presented in Figure 3.24. These concentration data will be converted to a per unit volume basis when quantitative analysis of the data is conducted. Depth profiles of bromide concentrations for core and drill cuttings samples (Figures 3.25 and 3.26, respectively) are virtually identical in shape to the chloride profiles.

Depth profiles of chloride/bromide ratios in both drill cuttings and core samples for each Pilot Well are presented in Figures 3.27, 3.28 and 3.29. The high variability in these ratios is most likely due to errors in bromide concentration measurements which increase greatly near the detection level of the instrument/method.

The relatively high concentrations of chloride in the shallow subsurface suggest that evaporation rates are high compared to the downward movement of water under the present climate. The very low concentrations of chloride at depth suggest that this water entered the system under a much wetter climate where recharge rates compared to evaporation rates were much higher than present rates (Conrad, 1993). These data support the general conclusion made previously from hydraulic data (Section 3.4.2); that is, the net downward movement of water under the present climate is very low, and in fact there may be a net upward movement of water.

The large differences in the shapes of the chloride (and bromide) profiles in the upper portions of each Pilot Well may be due to a number of factors. Differences in the amount of surface water runoff at each Pilot Well site (which is in tum related to proximity to upland mountains and to the size of the drainage basin) will definitely affect the amount of infiltration, and ultimately, the accumulation of chloride and bromide. Variations in plant communities and their rooting habits affect relative amounts of evapotranspiration and infiltration, and therefore chloride and bromide concentrations. Finally, the relative rates of aggradation and erosion may play an important role in affecting the concentration profiles. 


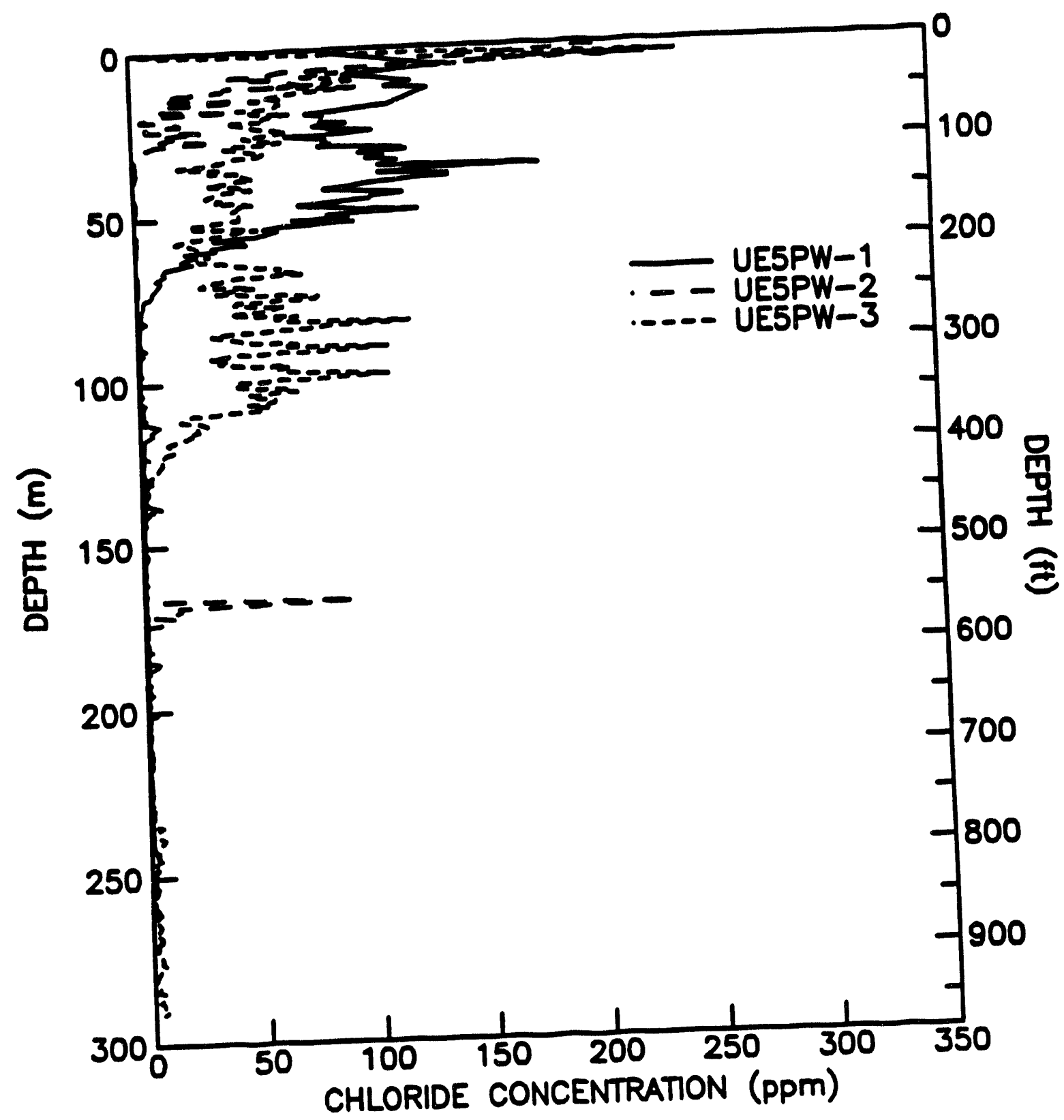

Figure 3.23 Depth profiles of dry soil chloride concentrations for drill cuttings samples from the Pilot Wells. 


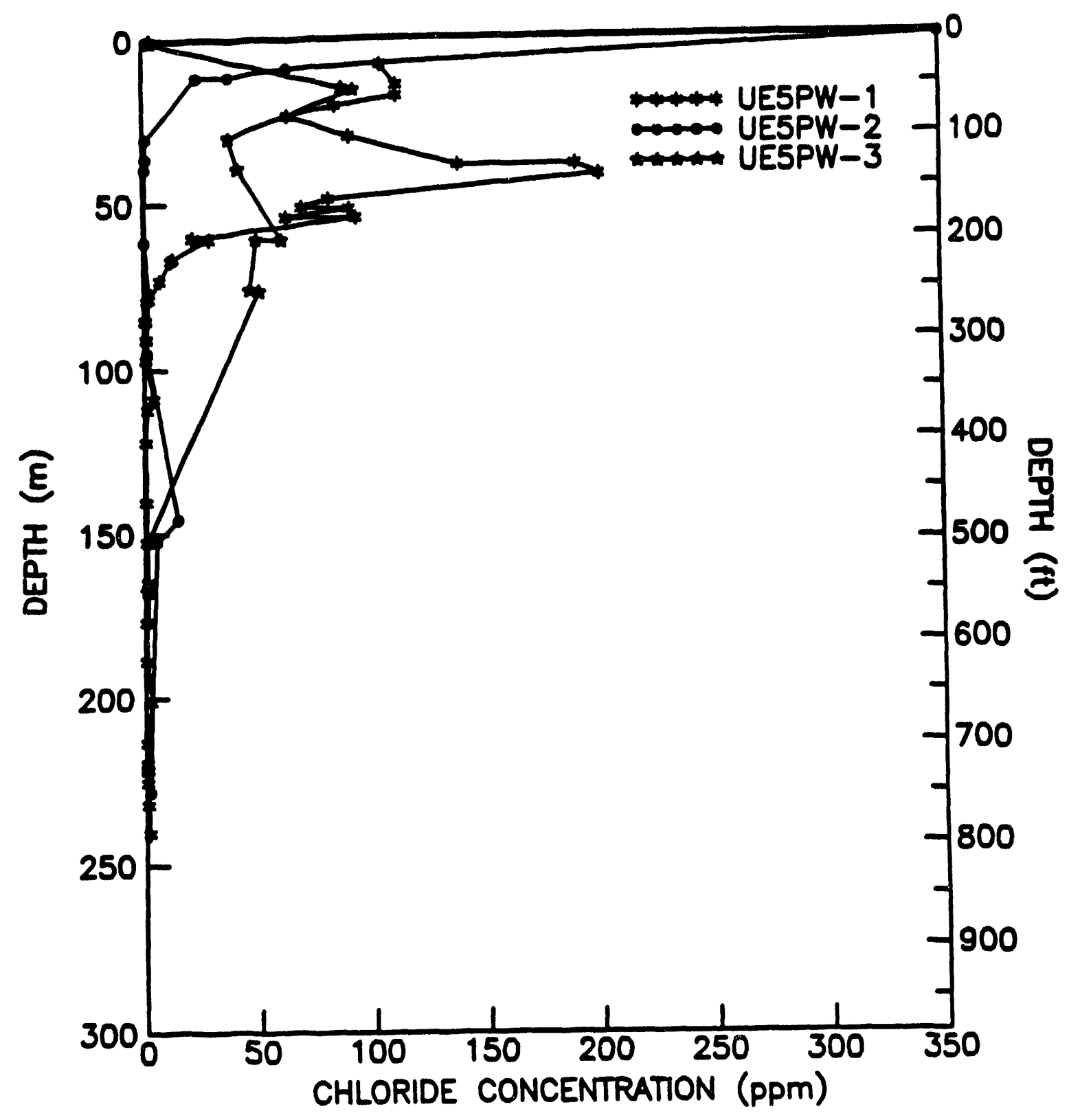

Figure 3.24 Depth profiles of dry soil chloride concentrations for core samples from the Pilot Wells. 


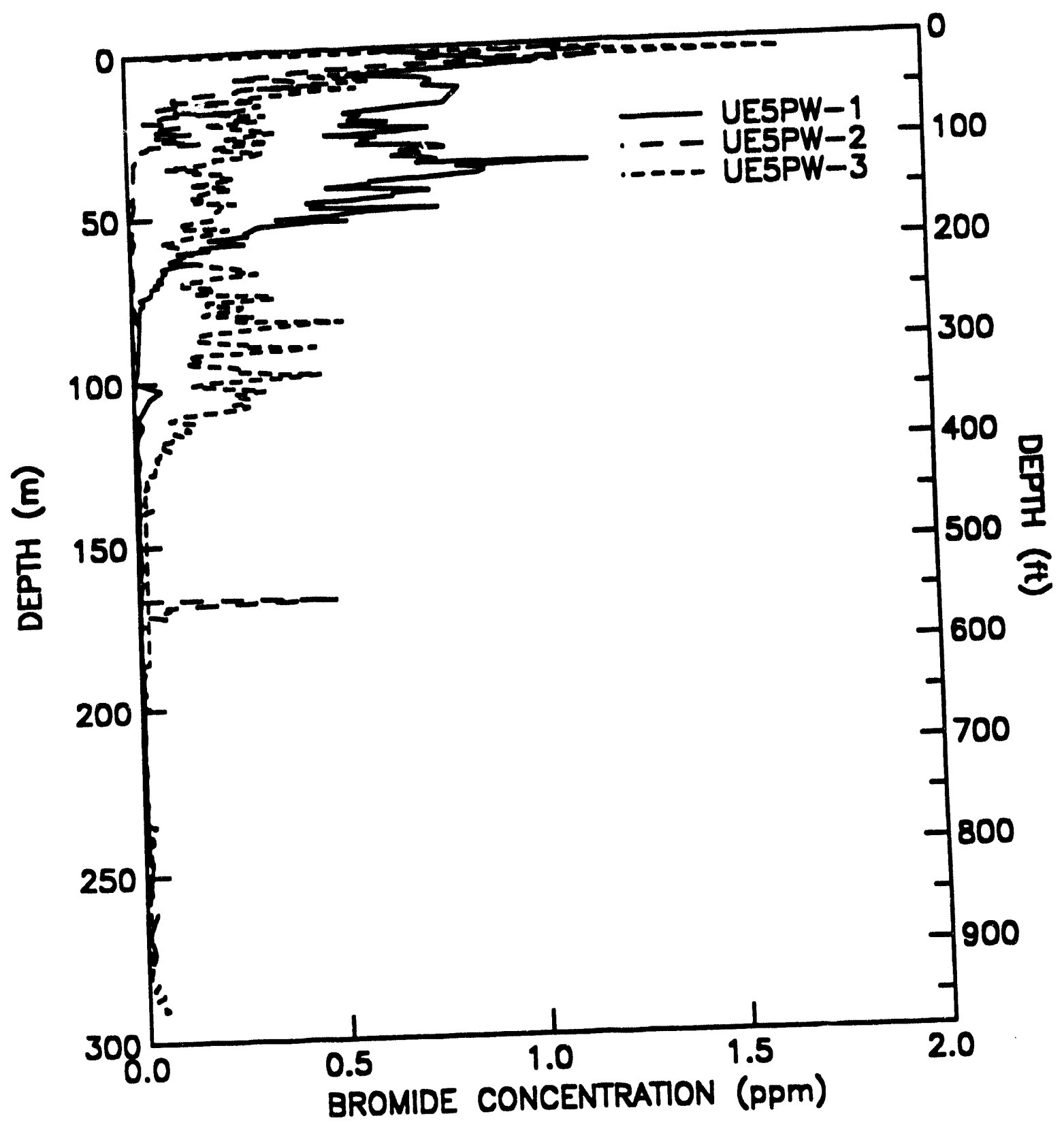

Figure 3.25 Depth profiles of dry soil bromide concentrations for drill cuttings samples from the Pilot Wells. 


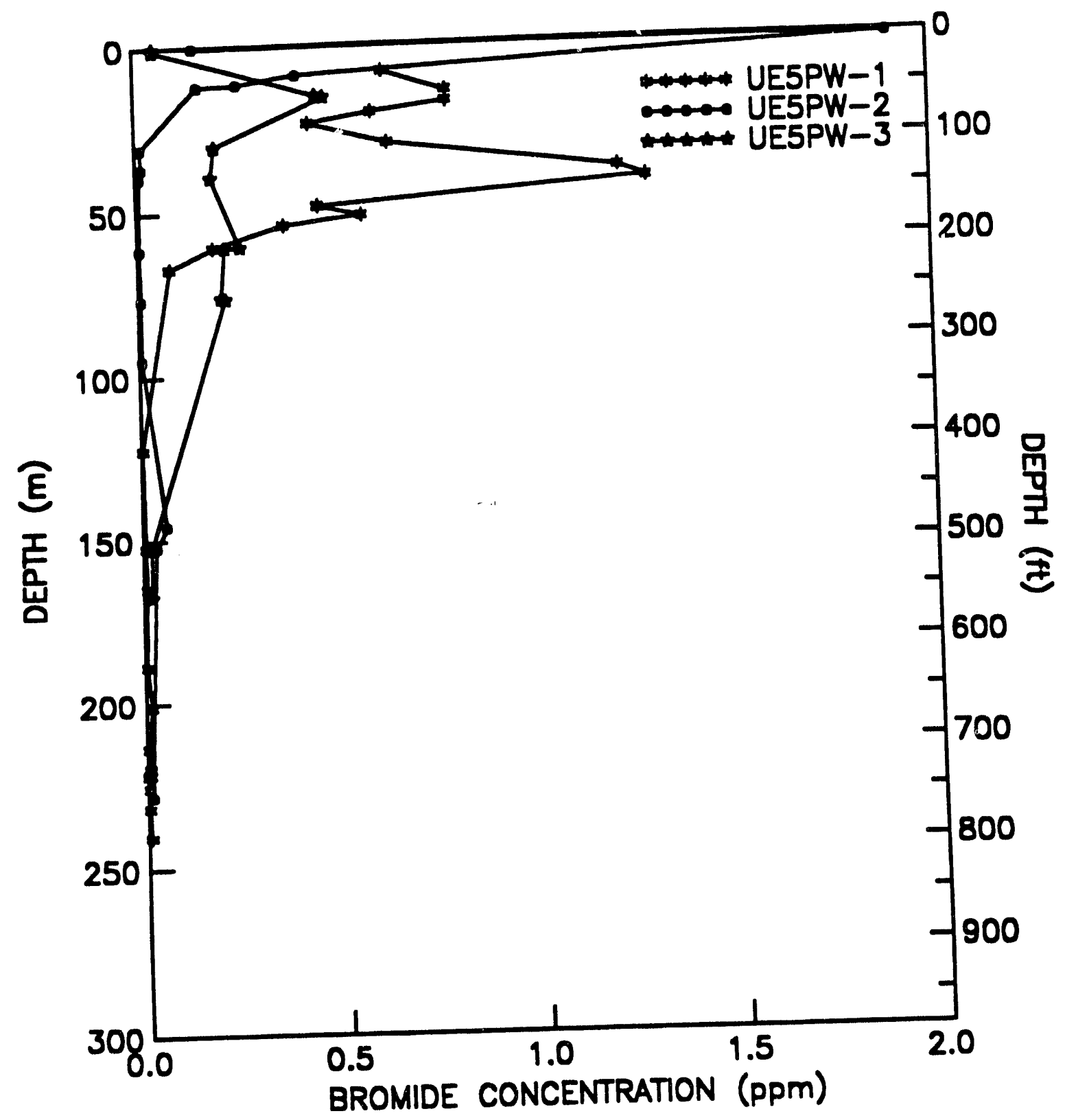

Figure 3.26 Depth profiles of dry soil bromide concentrations for core samples from the Pilot Wells. 


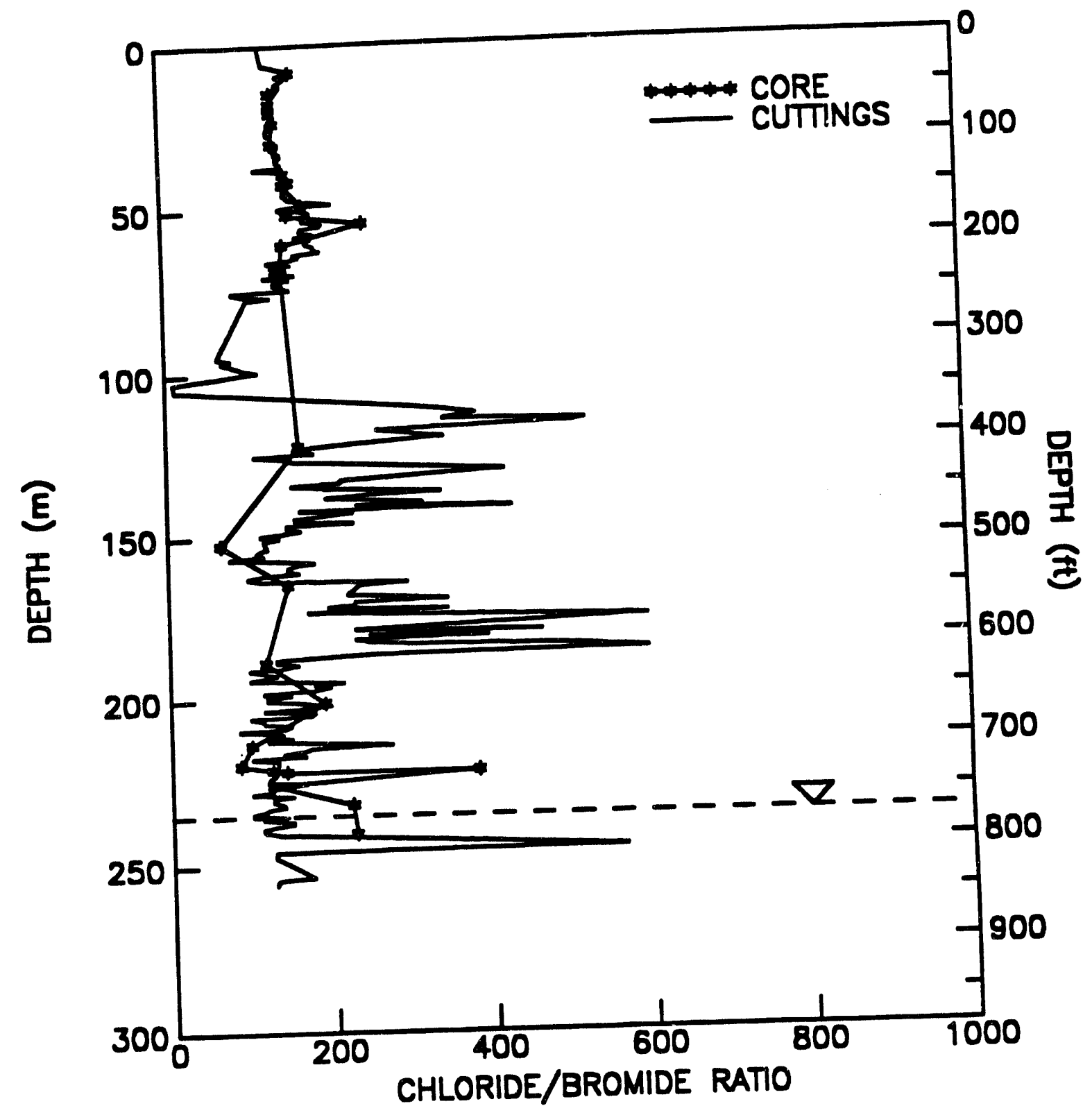

Figure 3.27 Depth profiles of dry soil chloride/bromide ratios for core and drill cuttings samples from UESPW-1. 


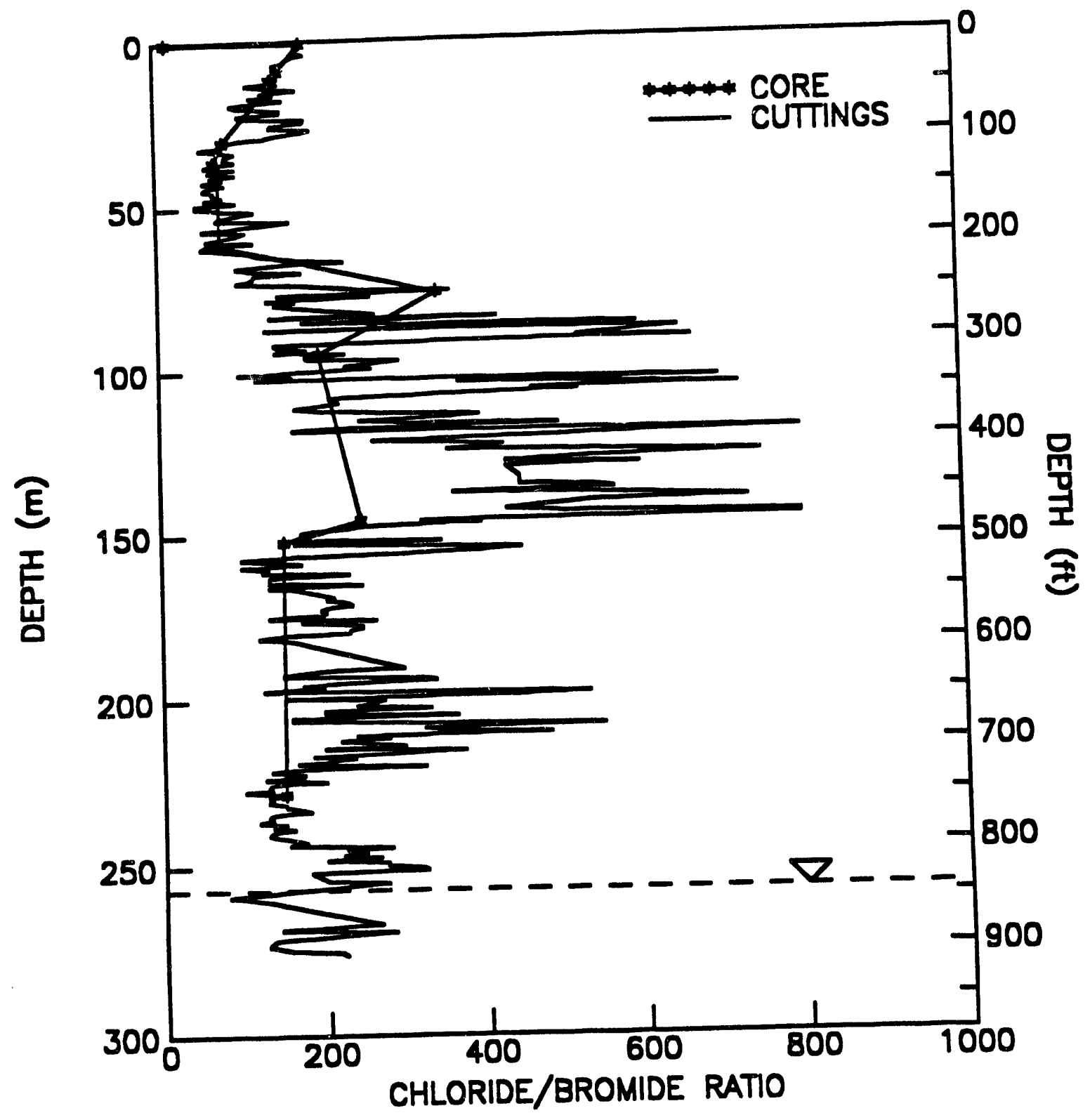

Figure 3.28 Depth profiles of dry soil chloride/bromide ratios for core and drill cuttings samples from UE5PW-2. 


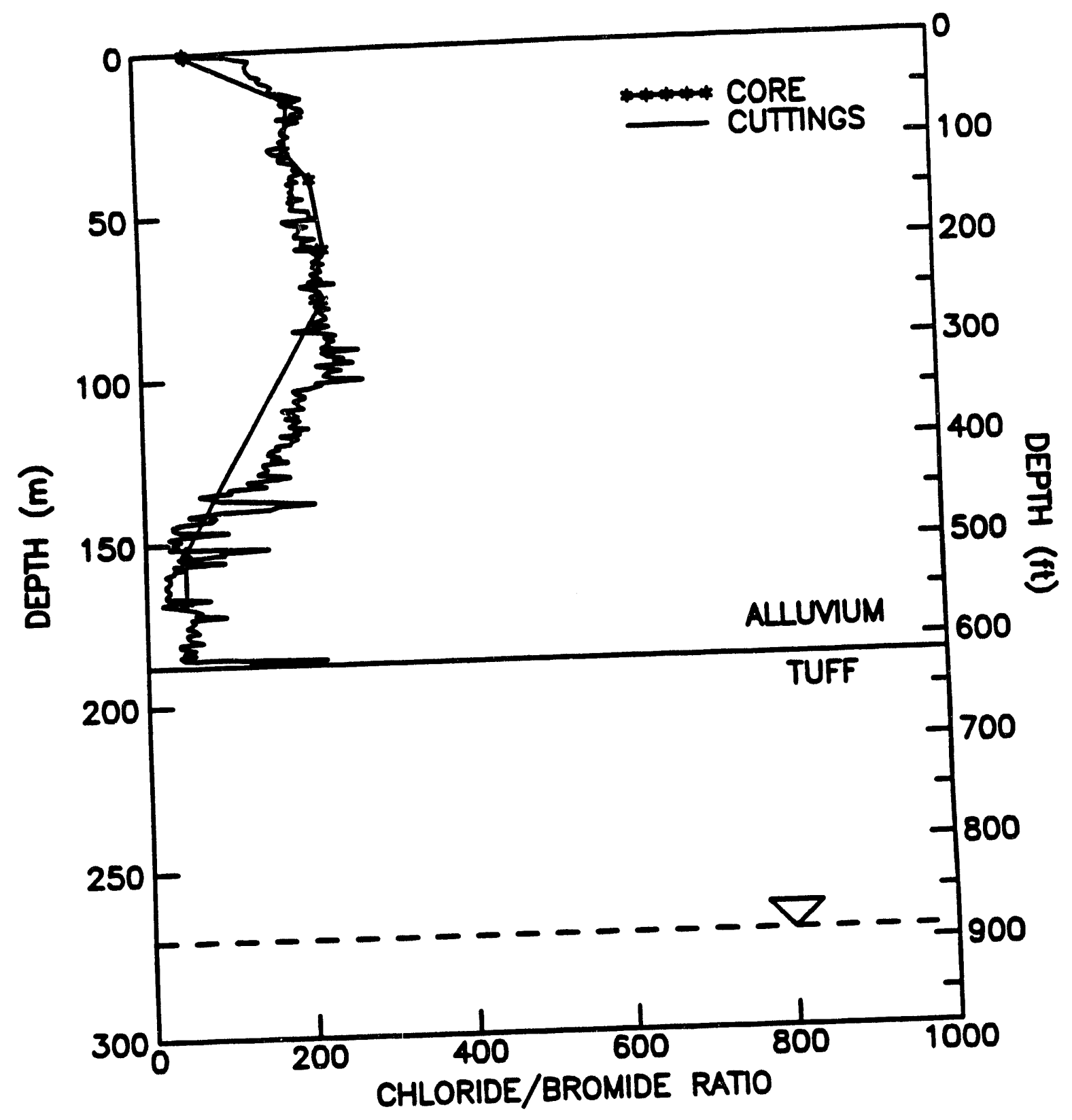

Figure 3.29 Depth profiles of dry soil chloride/bromide ratios for core and drill cuttings samples from UESPW-3. 


\subsubsection{Stable Isotope Profiles}

The stable isotopes of hydrogen $(\mathrm{D}$ and $\mathrm{H})$ and oxygen $\left({ }^{16} \mathrm{O}\right.$ and $\left.{ }^{18} \mathrm{O}\right)$ are excellent tracers of water movement because they are a component of the water molecule itself. Stable isotopes are used in unsaturated zone studies to infer the source of soil water and determine if evaporation has occurred. Results are reported as a ratio of light to heavy isotopes $(D / H$ and ${ }^{16} \mathrm{O} /{ }^{18} \mathrm{O}$ ) in delta notation $(\delta)$ relative to Standard Mean Ocean Water. Fractionation (a change in the ratio) occurs during phase change processes. Therefore, condensation and evaporation processes are both reflected in the isotopic ratios. The condensation of precipitation from the atmosphere occurs under very nearly thermodynamic equilibrium conditions, resulting in a linear relationship between hydrogen and oxygen isotopes in worldwide precipitation known as the meteoric water line (MWL). Evaporation of water generally occurs under non-equilibrium conditions and fractionation of the oxygen isotopes is greater than that of hydrogen isotopes. The water remaining behind in the evaporation process thus develops an isotopic composition that plots to the right of the MWL.

Stable isotope data from selected core samples from all Pilot Wells are presented in Appendix E.2. Depth profiles for these wells are presented in Figure 3.30. In general, these profiles show more enrichment of heavy isotopes in the upper vadose zone, suggesting that shallow water has been subjected to more evaporation. A plot of oxygen isotopic ratios from selected core samples, with the MWL for reference, is shown in Figure 3.31. The shallow samples plot to the right of the MWL on a line with a slope between 3.5 and 4 . This slope is consistent with the range found by Allison (1982) in experiments of water evaporating water from sand columns, and strongly supports the hypothesis (Section 3.4.2) that evaporation rates are high relative to the downward rate of water movement in the upper vadose zone under the present climate (J. Chapman, DRI, 1993, personal communication).

\subsubsection{Cosmogenic Chlorine-36 Data}

The radioisotope chlorine-36 $\left({ }^{36} \mathrm{Cl}\right)$ is continually produced in the upper atmosphere. This isotope together with the stable isotope, $\mathrm{Cl}$, (Section 3.5.1) is dissolved in ionic form in precipitation and enters the ground via infiltration. During periods of geomagnetic field fluctuations, increased production of ${ }^{36} \mathrm{Cl}$ is thought to occur (Blinov, 1988). Further, these field fluctuations and associated changes in ${ }^{36} \mathrm{Cl}$ production rates can possibly be dated. The relative magnitude of the ratios of these isotopes in the profiles provides information about the age of the soil water.

The depth profile of ${ }^{36} \mathrm{Cl} / \mathrm{Cl}$ ratios from selected UESPW-1 core samples is plotted in Figure 3.32. These data are presented in tabular form in Appendix E.2. Present day precipitation yields ${ }^{36} \mathrm{Cl} / \mathrm{Cl}$ ratios in the range of 450 to 550 times $10^{-15}$. The ratios found at depths up to $30.5 \mathrm{~m}(100 \mathrm{ft})$ are elevated above present-day conditions, suggesting that they were produced during the most recent period of the geomagnetic field fluctuations (Conrad, 


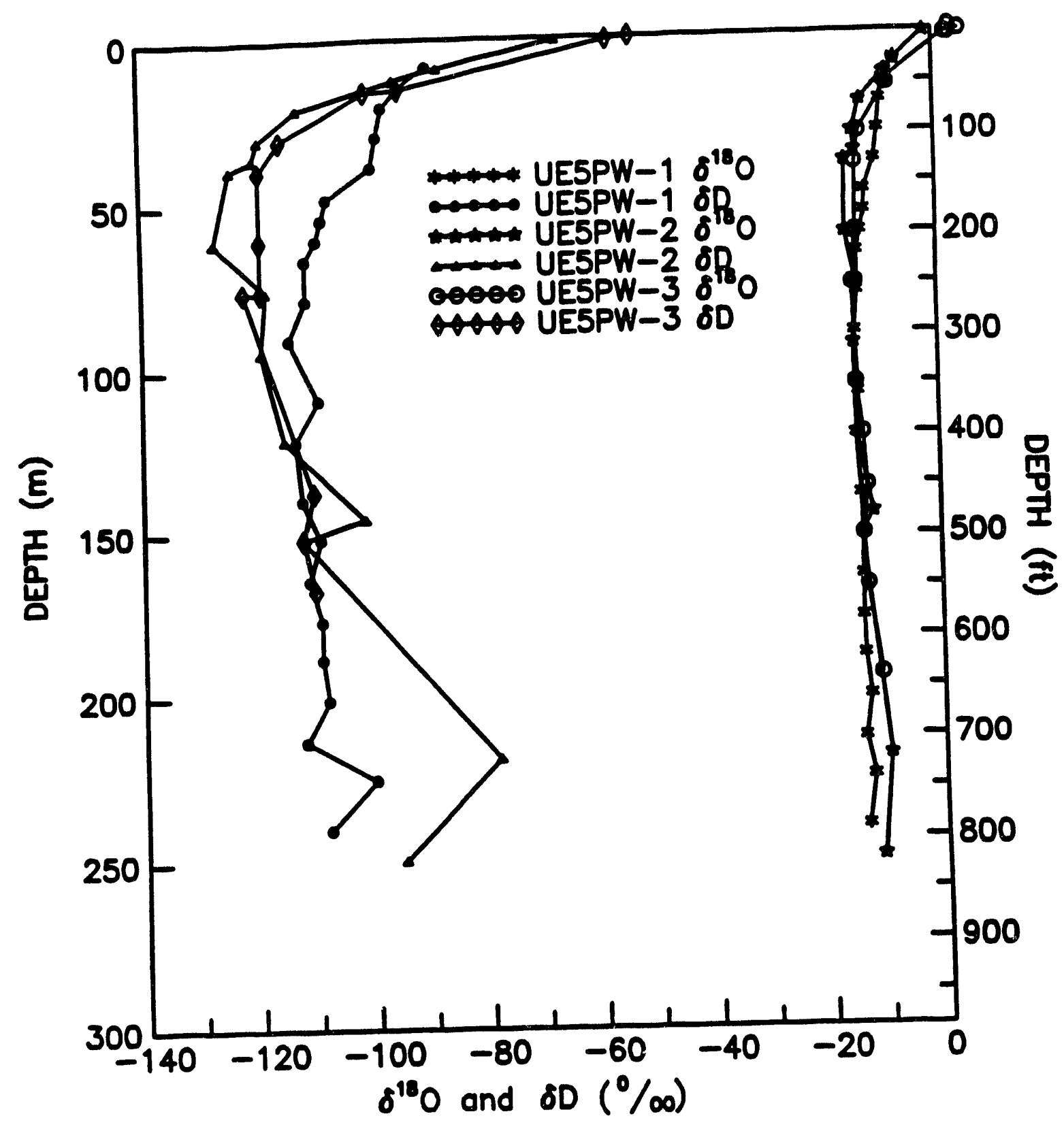

Figure 3.30 Depth profiles of stable isotope data for core samples from the Pilot Wells. 


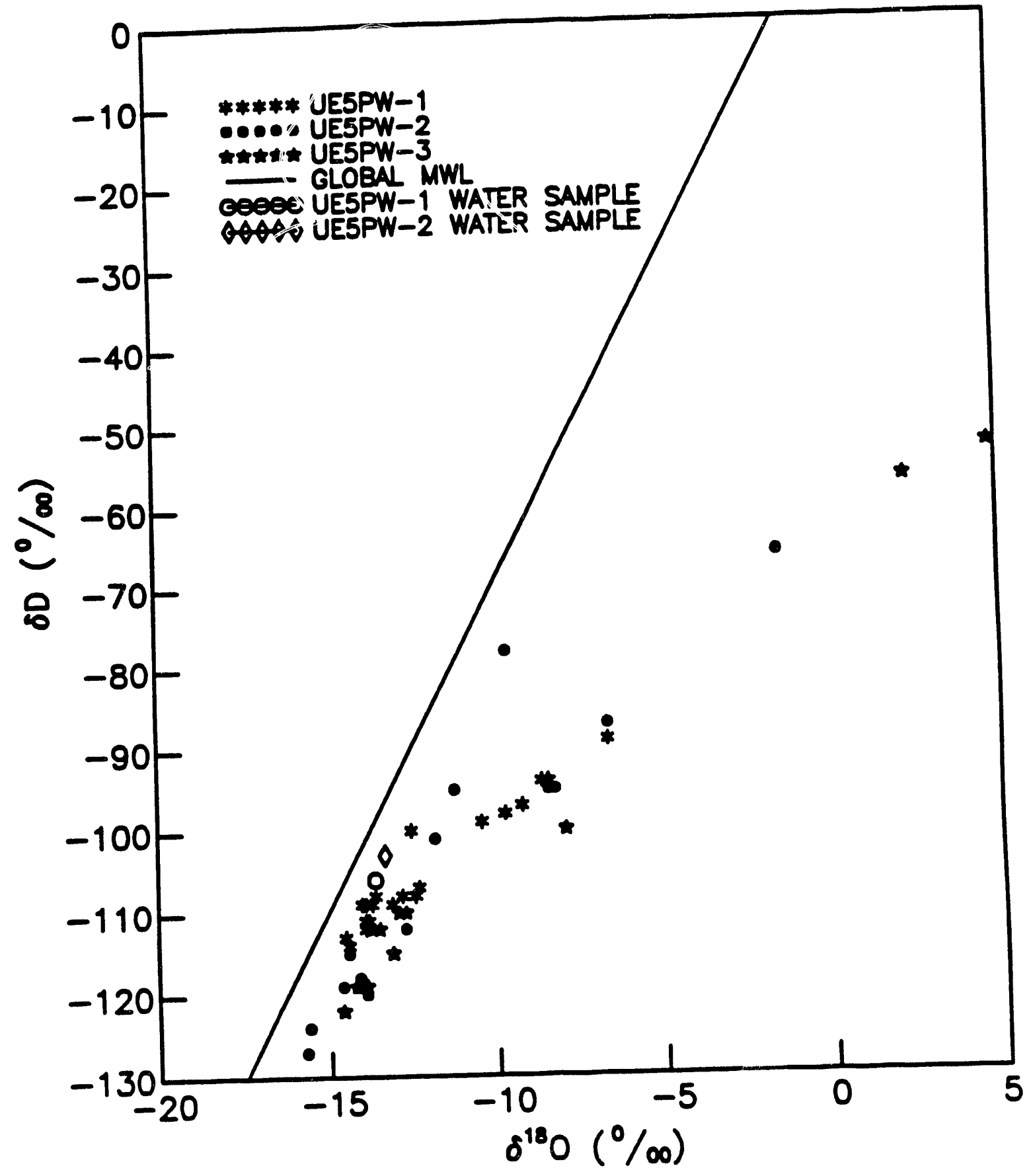

Figure 3.31 Comparison of measured stable isotopes for core and water samples from the Pilot Wells with stable isotope data for the global Meteoric Water Line (MWL). 


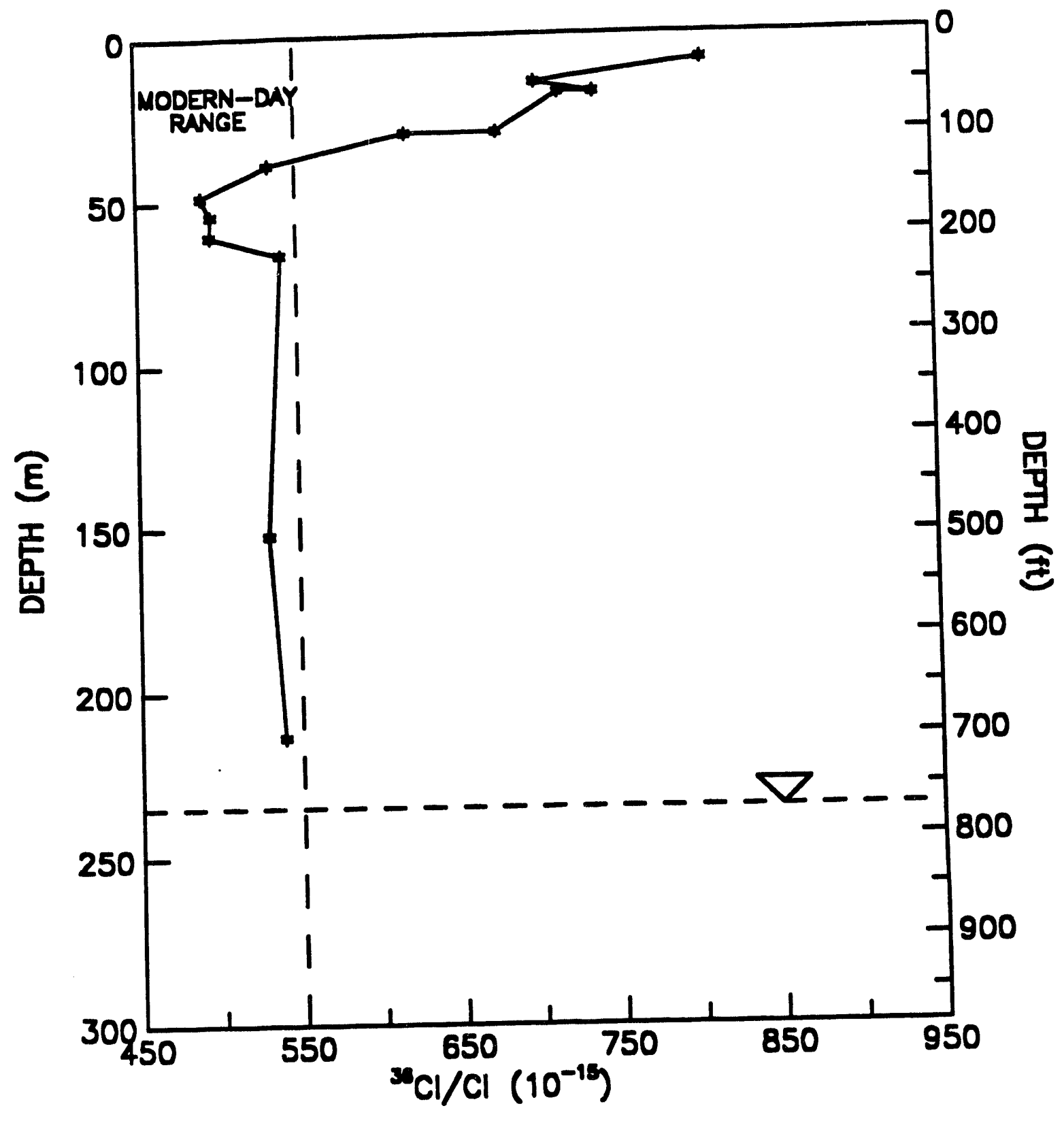

Figure 3.32 Depth profile of ${ }^{36} \mathrm{Cl} / \mathrm{Cl}$ ratios for core samples from UESPW-1. 
1993). Since this last period of fluctuations is thought to have occurred approximately 15,000 yrs ago, it has taken at least this amount of time for water to reach a depth of $30.5 \mathrm{~m}$. These elevated ratios have also been found in pack rat middens which have been tentatively dated to be approximately 21,000 yrs old by ${ }^{14} \mathrm{C}$ dating methods (Phillips et al., 1988). These data are consistent with both the hydraulic parameter data and the previously discussed environmental tracer data which indicate that the downward rate of liquid water movement is extremely slow if not zero.

\subsubsection{Soluble Sulfate}

Sulfate is not generally considered an environmental tracer because it is far less mobile than chloride and bromide for a number of reasons, including the lower solubility of sulfate salts. Moreover, there are many potentially important sources of sulfate, in addition to rainfall and runoff, which complicate the interpretation of depth concentration profile data. These sources include a number of common secondary minerals (e.g., gypsum) which occur in soils, alluvium, and source rock. Even with these complicating factors, sulfate depth profile data provide useful additional information concerning the relative importance of evaporation and infiltration processes under the present arid climate, as well as under a previous, more humid climate. These data are discussed below.

Soluble sulfate measurements were made on all core and drill cuttings samples from UESPW-2 and UESPW-3. Only a few samples from UESPW-1 were analyzed for soluble sulfate because the decision to add this measurement to the suite of wet chemical analyses (which included inorganic and organic carbon, chloride, and bromide) was made near the completion of testing on UESPW-1. Depth profiles of sulfate data from drill cuttings samples are presented for all three Pilot Wells in Figure 3.33, tabular data for both core and drill cuttings samples are presented in Appendix E.2, and descriptive statistics for the data in the lower vadose zone are presented in Table 3.3.

The data from drill cuttings samples for both UESPW-2 and UESPW-3 show relatively high and variable concentrations of sulfate in the upper portion of the profile and much lower and less variable concentrations in the lower portion of the profile. These profiles are somewhat similar in shape to chloride and bromide profiles (Section 3.5.1), however the depth at which these concentrations decrease to lower values is much shallower for sulfate. These differences are probably due to the lower mobility of the sulfate anion resulting (at least in part) from the generally lower solubility of sulfate salts compared to chloride and bromide salts.

In summary, these sulfate concentration profiles support the picture of water movement in the vadose zone suggested by the analysis of the other environmental tracers. In particular, these profiles imply under the present arid climate the liquid water which moves into the upper vadose zone moves out of the vadose zone primarily by vapor flow in response to a 


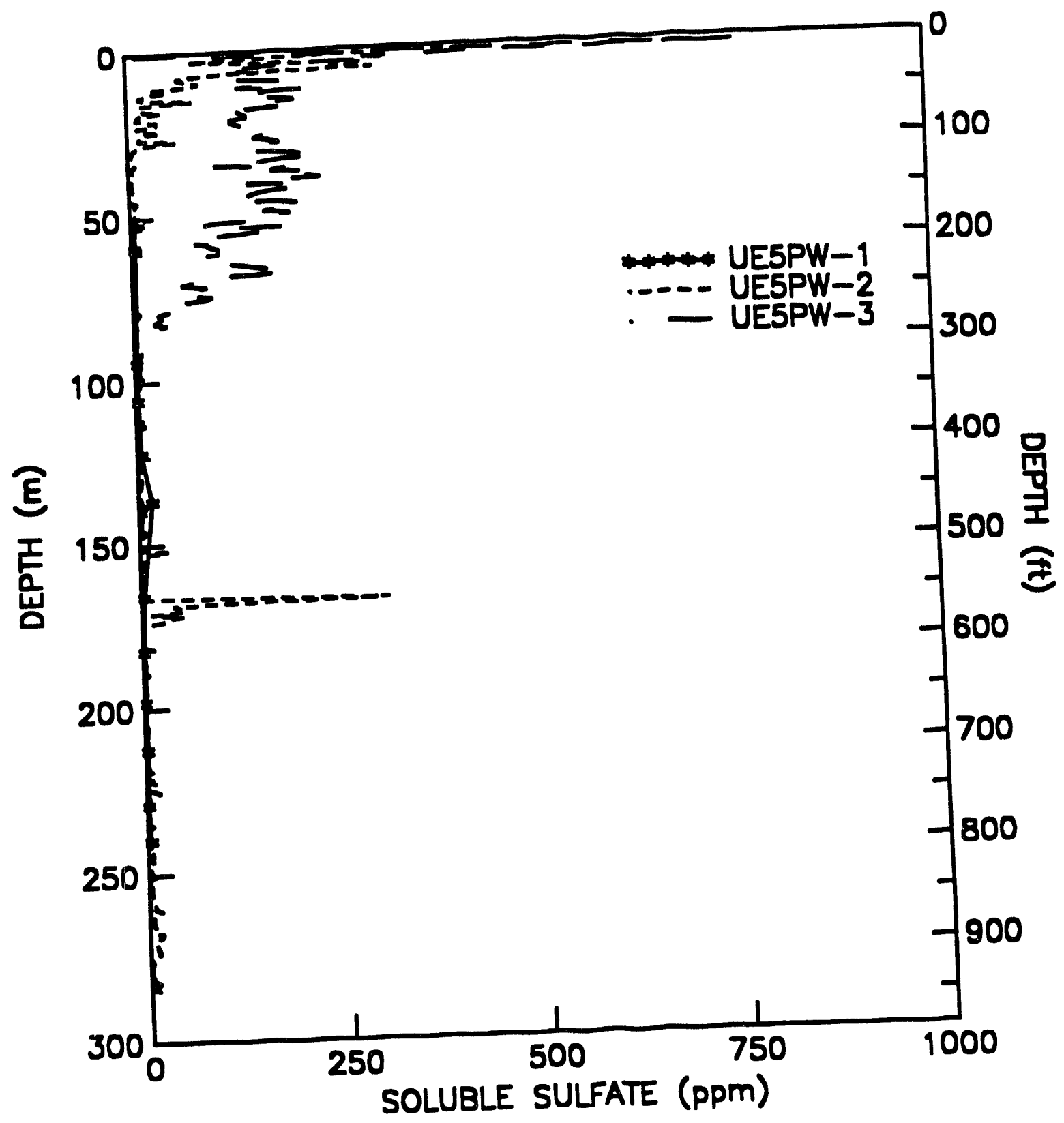

Figure 3.33 Depth profiles of soluble sulfate for drill cuttings samples from the Pilot Wells. 
high evaporative demand, and that the water which is presently in the lower vadose zone. infiltrated under a more humid climate where evaporation was not an important process.

\subsection{Sampling and Analysis of Core Samples for Hazardous and Radiological Parameters}

Alluvium samples were periodically collected during drilling and analyzed for selected hazardous and radiological parameters. The purpose of these analyses was to determine if core samples and the borehole were being contaminated by drilling and/or if the borehole had penetrated any contaminated regions.

Intact core samples were collected for analysis of volatile and semi-volatile organic compounds. Drill cuttings samples were collected for analysis of Total Kjeldahl Nitrogen (TKN), total metals (As, $\mathrm{Ba}, \mathrm{Cd}, \mathrm{Cr}, \mathrm{Pb}, \mathrm{Se}, \mathrm{Ag}$ and $\mathrm{Hg}$ ) and photon emitting radionuclides. Sample collection and field quality assurance procedures are described in a sampling and analysis TP (Table 2.1). In addition, these procedures contain additional information concerning sampling and analytical methods. The results of these analyses are tabulated in Appendix E.4.

The analytical results indicate that the concentrations of these constituents measured in core and drill cuttings were consistent with expected background levels. That is, elevated levels were not encountered while penetrating the thick vadose zone sediments and the upper portion of the alluvial aquifer.

Low levels of several volatile organic compounds, known to be common laboratory contaminates, were sporadically detected in alluvium samples. The presence of these compounds is likely attributable to laboratory contamination. Semi-volatile organic compounds were not detected. Total metals analyses and TKN analyses were characteristic of uncontaminated soils. The only radionuclides detected were naturally occurring primordial radionuclides. 


\subsection{FIELD TESTING METHODS AND RESULTS}

\subsection{Preliminary Surface Surveys of Potential Contaminants at Drill Sites}

Frenchman Flat and the Area 5 RWMS have been the site of numerous activities that could potentially have contaminated surface soils with hazardous constituents and radionuclides. From 1951 to 1961 Frenchman Flat, and Yucca Flat to the north, were the site of numerous atmospheric nuclear weapons tests. After 1961, several underground nuclear tests were conducted $4.4 \mathrm{~km}(2.4 \mathrm{mi})$ to the north and at several locations to the south of the Area 5 RWMS. Several safety tests also have been performed in the vicinity of the Area 5 RWMS. Safety tests involve chemical detonation of nuciear weapon components and may result in the dispersion of actinide contamination. Also, Area 5 has been the site for chemical spill tests. Finally, all three drill sites had been disturbed to some extent by vehicle traffic.

Prior to initiating drilling operations, surface soil and near-surface gas samples were collected from the Pilot Well sites, and analyzed to insure that the ground surfaces at these sites were free of elevated levels of contaminants that could be spread downward as a result of drilling. The results of these sampling and analysis activities are described below.

\subsubsection{Surface Soil Sampling, Analysis, and Results}

Surface soil samples were collected at each drill site prior to preparation and after grading and compaction. The purpose of these surveys was to determine if contamination existed at any of the drill sites at concentrations that could potentially result in contamination of the borehole through drilling activities. Samples from unprepared sites were analyzed for oil and grease, Total Petroleum Hydrocarbons (TPH) and photon emitting radionuclides. Samples from prepared drill sites were analyzed for all the above parameters plus plutonium isotopes.

Samples were collected from $20-\mathrm{cm}(7.9-\mathrm{in})$ by $20-\mathrm{cm}$ by $2-\mathrm{cm}(0.8-\mathrm{in})$ deep cells selected randomly from a $30-\mathrm{m}$ ( $98-\mathrm{ft})$ by $30-\mathrm{m}$ grid centered at the borehole. Four random samples were collected from each of the unprepared and prepared sites, the only exception being the unprepared site at UESPW-1. The UESPW-1 site was disturbed by vehicle traffic prior to sampling for TPH and oil and grease. Due to the extent of the disturbance it was impossible to collect samples from this site using a randomized design. Therefore, three TPH and oil and grease samples were collected $15.2 \mathrm{~m}(50 \mathrm{ft})$ east, west and north of the borehole. Finally, an additional grab sample was collected from a dark stained area southeast of the borehole location at the unprepared UESPW-2 site.

Details of sample collection and analytical methods together with the tabular testing results are given in Appendix F.1.1. No analyte was detected at concentrations that would have presented potential contamination problems during drilling operations. 


\subsubsection{Near-Surface Radon and Tritium Gas Sampling, Analysis, and Results}

Tritium oxide and radon-222 $\left.{ }^{222} \mathrm{Rn}\right)$ soil gas surveys were conducted at each of the Pilot Well locations in the near-surface soils prior to drilling operations. Tritium samples were obtained as water vapor (tritium oxide) and analyzed to insure that the Pilot Well sites were free of elevated levels of tritium near the ground surface that could be harmful to human health and/or could be carried downward by the drilling operations and contaminate the groundwater. Samples for ${ }^{222} \mathrm{Rn}$ were collected and analyzed to establish background concentrations which are dependent on site specific lithologies. In addition, ${ }^{222} \mathrm{Rn}$ samples were collected over time as part of a preliminary study of the effects of barometric pumping on the movement of gases in the near-surface.

Soil gas samples for both tritium oxide and $222 \% \mathrm{n}$ were collected from the same stainless steel sampling lines driven to depths of approximately $0.9,2.7$, and $6.4 \mathrm{~m}(3,9$, and $21 \mathrm{ft})$ at each of the locations using a hydraulically driven probe. At the UE5PW-3 location the hydraulic probe used to install sample lines met refusal at $5.2 \mathrm{~m}$ (17 ft) rather than the target depth of $6.4 \mathrm{~m}$ for the deepest sampling point. After the hyoraulic probe was driven to the depth of interest, a sample line with a filter tip was run to the bottom of the probe borehole, sand was then stemmed around the tip, and finally bentonite was stemmed around the sample line to the ground surface to prevent preferential flow.

\subsubsection{Radon Soil Gas Surveys}

Details of radon-222 $\left({ }^{22} \mathrm{Rn}\right)$ sample collection and counting measurement methods together with radon concentration data are summarized in Appendix F.1.2. Soil gas concentrations of ${ }^{222} \mathrm{Rn}$ sampled at each of the three Pilot Well locations show increasing concentration and decreasing temporal variability with depth. The wider range of variability in the near-surface samples can probably be attributed to barometric pumping, while the trend of decreasing concentrations towards the surface is likely due to a combination of barometric pumping and the diffusion process across the zero concentration soil/atmosphere boundary.

At the UE5PW-3 site, located near the Massachusetts Mountains, the ${ }^{222} \mathrm{Rn}$ concentrations were approximately three times that found at the UESPW-1 and UESPW-2 drill sites. The higher concentration of ${ }^{222} \mathrm{Rn}$ in the soils at the UE5PW-3 site is probably due to a change in lithology (e.g., tuff units closer to the ground surface) with a higher uranium content.

\subsubsection{Tritium Soil Gas Surveys}

Descriptions of tritium oxide sample collestion and analysis methods as well as analytical results for all three Pilot Well sites are given in Appendix F.1.2. With the exception of the 0.9-m (3-ft) depth at UESPW-1, all sample activities were below detection limits. Detection 
limits ranged between 592 to $1,776 \mathrm{Bg} / \mathrm{m}^{3}(0.16$ to $0.48 \mathrm{pCi} / \mathrm{ml})$ depending on sample size and counting time.

Samples from the UESPW-1 site were collected on October 24, 1991 and counted for $100 \mathrm{~min}$. This count of the sample from the $0.9-\mathrm{m}$ depth gave a sample activity of $1,850 \mathrm{~Bq} / \mathrm{m}^{3}(0.500 \mathrm{pCi} / \mathrm{ml})$ with a sample error of $825 \mathrm{~Bq} / \mathrm{m}^{3}(0.223 \mathrm{pCi} / \mathrm{ml})$ and a minimum detectable amount of $1,306 \mathrm{~Bq} / \mathrm{m}^{3}(0.353 \mathrm{pCi} / \mathrm{ml})$. The other samples were below the minimum detectable amount. The samples were then recounted using a $300 \mathrm{~min}$ count time resulting in a sample activity for the sample from the $0.9-\mathrm{m}$ depth of $1,550 \mathrm{~Bq} / \mathrm{m}^{3}$ $(0.419 \mathrm{pCi} / \mathrm{ml})$ and a sample error of $470 \mathrm{~Bq} / \mathrm{m}^{3}(0.127 \mathrm{pCi} / \mathrm{ml})$. The other samples were again found to be below the minimum detectable amount of $725 \mathrm{~Bq} / \mathrm{m}^{3}(0.196 \mathrm{pCi} / \mathrm{ml})$ using a single background count.

In order to firmly establish if these results were due to laboratory contamination or actual sample activity, a second sample was obtained from the UESPW-1 site on nctober 30, 1991. The results confirmed the original sampling, indicating very low environmental levels of tritium oxide at the $0.9-\mathrm{m}$ depth, and less than detection limits at the $2.7-\mathrm{m}$ and $6.4-\mathrm{m}(9-\mathrm{ft}$ and $21-\mathrm{ft}$ ) depths.

It should be emphasized that tritium oxide levels were in all cases below or very near to both detection levels and environmental background levels (even the 0.9-m depth sample in UESPW-1). Based on these results all sites were considered to be essentially free of elevated tritium oxide levels and were considered acceptable sites for drilling.

\subsection{Surface Geophysical Surveys}

A set of Schlumberger resistivity soundings as well as total field and gradiometer magnetic field data were obtained at each of the Pilot Well locations. These data were collected prior to drilling activities in order to establish background control data before the site wals disturbed by the cultural effects of drilling operations. The primary purpose of these surveys was to attempt to obtain preliminary information about any subsurface lithologic/hydrologic feature that could be used to help design and focus future sampling and analysis activities. These surveys would also provide the opportunity to determine if in fact these geophysical tools could be used to help define lithologic/hydrologic features (as determined from analysis of core and drill cuttings samples) in thick unsaturated alluvial settings. If a positive correlation was found between geophysical tool response and lithology, these geophysical methods would be useful in delineating the lithology at other sites (where borehole data do not exist) with thick sections of unsaturated alluvium. The resistivity and magnetic surveys were conducted under the applicable SOPs and TPs found in Table 2.1. 


\subsubsection{Resistivity Surveys}

The resistivity soundings were performed with a Schlumberger array and were taken using an ABEM SAS 300C Terrameter with an SAS 2000 booster capable of operating up to $500 \mathrm{ma}$ transmitted current. The soundings were centered over each borehole location and oriented in a manner which would minimize cultural effects from pipelines, powerlines, fences, and other structures. Current electrode separations $(A B / 2)$ were located logarithmically ranging from 0.6 to $853.4 \mathrm{~m}$ ( 2 to $2,800 \mathrm{ft}$ ). The receiver dipole $(\mathrm{mn} / 2)$ length ranged from 0.3 to $45.7 \mathrm{~m}(1$ to $150 \mathrm{ft})$ as required by signal strength. The resistivity sounding data and log plots of these data locations are found in Appendix F.2.1.

Apparent resistivity, $\rho$, in $\Omega-\mathrm{m}$, was calculated by:

$$
\rho=V / I\left[(A B / 2)^{2}-(\mathrm{mn} / 2)^{2}\right] \pi / \mathrm{mn}
$$

where $\mathrm{V}$ is the received voltage, $\mathrm{I}$ is the traismitted current, $\mathrm{AB}$ is the current electrode separation in meters, and $\mathrm{mn}$ is the receiver separation in meters.

The resistivity soundings (Figure 4.1) at UESPW-1 and UESPW-2 are similar and show high resistivity in the near-surface and decrease with depth. The water table is evident as the low resistivity bottom layer occurring past the $304.8 \mathrm{~m}(1,000 \mathrm{ft}) \mathrm{AB} / 2$ separation on each sounding. Overall resistivities are slightly higher at UESPW-2 than at UESPW-1 with the exception of the very near-surface reading.

Orthogonal Schlumberger arrays were used at UESPW-1 to determine anisotropic and threedimensional effects. Both soundings are remarkably similar indicating the alluvium is both isotrcpic and lacking in any three-dimensional effects in this area. Low resistivity was observed on both of these crossed arrays at an $A B / 2$ of 170.7 and $405.4 \mathrm{~m}$ (560 and $1,330 \mathrm{ft}$ ). It is thought that these features are artifacts caused by interference arising from man-made structures.

The sounding data obtained at UESPW-3 are clearly different than those seen at the other Pilot Well locations. It should be noted that the receiver-dipole porous-pot contact on this resistivity line became as high as $20,000 \mathrm{ohms}$, and the data may be somewhat noisy due to this. The layering seen on this line is a low/moderate/low/high/low sequence, whereas the other Pilot Wells showed a high/low/low layering. Finally, the deep high resistivity response at UESPW-3 is probably due to the volcanic tuffs which were encountered during drilling at $188.2 \mathrm{~m}(617.5 \mathrm{ft})$ below the ground surface, and the low resistivity bottom layer is probably the water table which was measured at approximately $271 \mathrm{~m}(888 \mathrm{ft})$. 


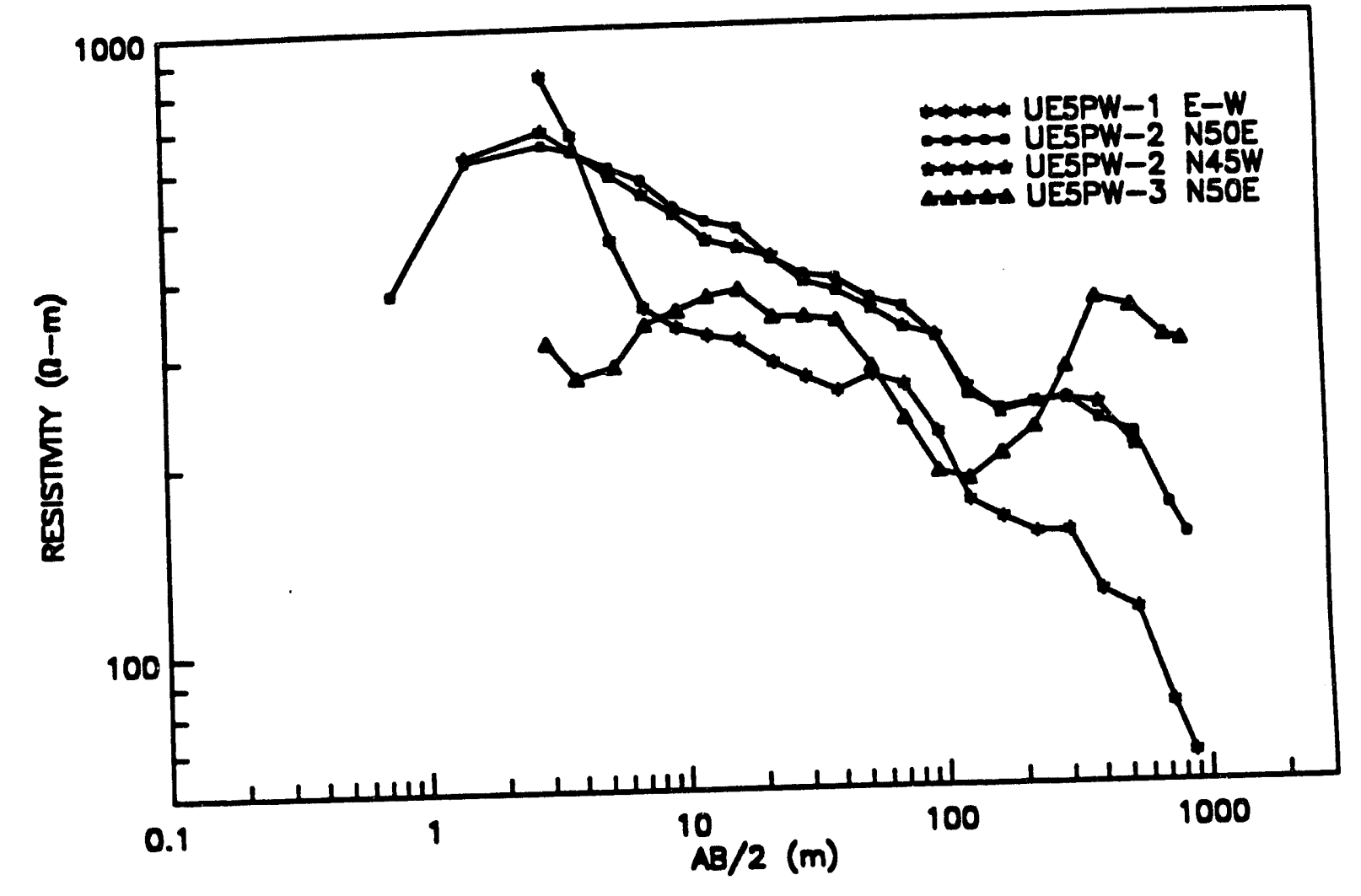

Figure 4.1 Resistivity soundings. 


\subsubsection{Magnetic Surveys}

The magnetometer surveys were centered at these locations with $304.8-\mathrm{m}(1,000-\mathrm{ft})$ profiles

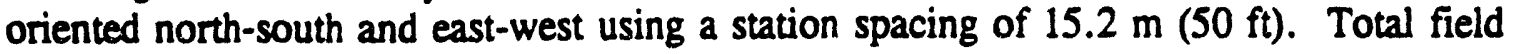
magnetic data, as well as the vertical gradient, were obtained using a GEM Systems GSM-19 Overhauser magnetometer/gradiometer. Three station in-phase and out-of-phase VLF data were also obtained while conducting the survey, but due to the lack of any significant response the data will not be reported here. A GEM systems recording base station was used to correct for diurnal variations and to monitor for magnetic storms during conduct of the survey. The base station and survey magnetometer clocks were synchronized which allowed discrete time corrections to be done for the reduction of diumal data. Magnetic survey data are found in Appendix F.2.2.

The total field and gradient data collected at each of the Pilot Well locations are uniform and well behaved which would be expected in homogeneous sedimentary alluvial basin fill. The total field intensity at UESPW-1, UESPW-2, and UESPW-3 is 50,975, 50,967, and 50,969 nanoteslas, respectively, while vertical gradients typically range between -2 to -6 nanoteslas $/ \mathrm{m}$. It is thought that these local disturbances of the gradient and total field are artifacts caused by interference arising from the same man-made cultural effects mentioned above in relation to resistivity surveys. Additional surveys in Frenchman Flat of the lithologic inhomogeneity are required to determine if magnetic surveys are useful tools to help delineate lithologies in alluvial basins with thick unsaturated zones.

\subsection{Borehole Geophysical Logging Surveys}

Borehole geophysical logging was conducted in each Pilot Well during different stages of drilling to attempt to obtain additional stratigraphic, mineralogic, hydrologic, and borehole condition information. This logging was conducted by Century Geophysical Corporation, Chino Valley, Arizona, under the direction of SPS personnel according to the applicable QA procedures listed in Table 2.1.

\subsubsection{Description of Borehole Logging Activities}

Borehole logs were conducted in each Pilot Well upon completion of three different stages of drilling and stemming activities. Each logging episode was conducted, at least in part, inside cased portions of each Pilot Well. The lower part of the tuff interval in UESPW-3 is the only uncased portion of borehole that was logged. Logging episodes in each Pilot Well, including casing diameter, casing depths, type of log conducted, and logging tool model number are summarized in Table 4.1 . 
Table 4.1 Borehole geophysical logging episodes in the Pilot Wells.

\begin{tabular}{|c|c|c|c|c|c|c|c|c|c|c|}
\hline \multirow[b]{2}{*}{ Borchole } & \multirow[b]{2}{*}{$\begin{array}{l}\text { Episode } \\
\text { Number }\end{array}$} & \multirow[b]{2}{*}{ Date } & \multirow[b]{2}{*}{$\begin{array}{l}\text { Casing } \\
\text { Outside } \\
\text { Diameter } \\
\text { mm (in) }\end{array}$} & \multirow[b]{2}{*}{$\begin{array}{l}\text { Casing } \\
\text { Depth } \\
\text { m (n) }\end{array}$} & \multicolumn{6}{|c|}{ Los type and Tool model number } \\
\hline & & & & & $\begin{array}{c}\text { Gamma Ray } \\
\text { (Natural } \\
\text { Gamma) }\end{array}$ & $\begin{array}{l}\text { Gamma } \\
\text { Density }\end{array}$ & Caliper & $\begin{array}{l}\text { Spectral } \\
\text { Gamma } \\
\text { (KUT) }\end{array}$ & Neviron & Deviation \\
\hline UESPW-1 & 1 & $4 / 20 / 92$ & $\begin{array}{c}273.0 \\
(10.750)\end{array}$ & $\begin{array}{c}112.0 \\
(367.5)\end{array}$ & 9030 & 9030 & 9030 & 9080 & 9055 & $\bullet$ \\
\hline & 2 & $6 / 16 / 92$ & $\begin{array}{r}273.0 \\
219.1 \\
(8.625)\end{array}$ & $\begin{array}{c}112.0 \\
255.1 \\
(837.0)\end{array}$ & 9035 & 9035 & 9035 & 9080 & 9071 & - \\
\hline & 3 & $2 / 24 / 93$ & $\begin{array}{c}73.0 \\
(2.875)\end{array}$ & $\begin{array}{c}250.5 \\
(822.0)\end{array}$ & $\bullet$ & $\bullet$ & $\bullet$ & $*$ & 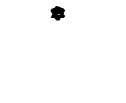 & 9095 \\
\hline UESPW-2 & 1 & $7 / 20 / 92$ & $\begin{array}{l}273.0 \\
219.1\end{array}$ & $\begin{array}{c}121.9 \\
(400.0) \\
167.9 \\
(551.0)\end{array}$ & $9035 * *$ & 9035 & 9035 & 9080 & 9055 & $*$ \\
\hline & 2 & $9 / 29 / 92$ & $\begin{array}{l}273.0 \\
219.1\end{array}$ & $\begin{array}{c}167.9 \\
259.1 \\
(850.0)\end{array}$ & 9035 & 9035 & 9035 & 9030 & 9071 & - \\
\hline & 3 & $2 / 25 / 93$ & 73.0 & $\begin{array}{c}271.3 \\
(890.0)\end{array}$ & $\bullet$ & $\bullet$ & $\bullet$ & $*$ & $\bullet$ & 9095 \\
\hline UESPW-3 & 1 & 9/28/92 & 273.0 & $\begin{array}{c}137.2 \\
(450.0)\end{array}$ & 9035 & 9035 & 9035 & 9010 & 9071 & $*$ \\
\hline & 2 & $11 / 12 / 92$ & $\begin{array}{l}273.0 \\
219.1\end{array}$ & $\begin{array}{c}137.2 \\
213.4 \\
(700.0)\end{array}$ & 9035 & 9035 & 9035 & 9080 & 9071 & $*$ \\
\hline & 3 & $2 / 25 / 93$ & 73.0 & $\begin{array}{c}289.6 \\
(950.0)\end{array}$ & $\bullet$ & $\bullet$ & $\bullet$ & $*$ & $\bullet$ & 9095 \\
\hline
\end{tabular}

\footnotetext{
- Logs not run during this logging episode.
} 
The first logging episode was conducted after driving the 273.0-mm (10.75-in) O.D. casing to roughly half the total planned depth of each well. In UESPW-2, a second $219.1-\mathrm{mm}$ (8.625-in) O.D. casing was advanced inside the 273.0-mm O.D. casing from 121.9 to $167.9 \mathrm{~m}$ (400 to $551 \mathrm{ft}$ ) before the first episode of logging could be conducted. Therefore logs in this borehole from 0 to $121.9 \mathrm{~m}$ ( 0 to $400 \mathrm{ft}$ ) were conducted inside telescoped $273.0-\mathrm{mm}$ and $219.1-\mathrm{mm}$ casings, and logs were run from 121.9 to $167.9 \mathrm{~m}$ inside the 219.1-mm casing only.

The second logging episode was conducted after drilling the approximate lower half of each borehole with 219.1-mm casing. This casing was run inside (telescoped) the 273.0-mm casing, therefore, second episode logs in the approximate upper half of each borehole were run inside two casings.

The final logging episode was conducted after removing the $273.0-\mathrm{mm}$ and $219.1-\mathrm{mm}$ casings and completing each well with an approximately $73.0-\mathrm{mm}(2.875$-in) O.D. stainlesssteel monitoring well casing. Vadose zone instruments were stemmed at different depths on the outside of this casing.

The first two logging episodes included neutron, density, natural gamma, and spectral gamma (potassium, uranium, and thorium [KUT]), and caliper logs. The caliper log data were obtained as part of the natural gamma and density tool output and are of use only in the uncased portion of the tuff in UESPW-3.

The final logging episode involved borehole deviation logging (inclinometer-gyro tool) only. More detailed equipment information, as well as graphs of the results from each borehole logging episode, are presented for each Pilot Well in Appendix F.3.

\subsubsection{Summary of Nuclear Logging Results}

Borehole geophysical log results in alluvium (Appendix F.3) will not be discussed in detail in this report because they provided little if any useful stratigraphic, mineralogic, and hydrologic information other than to confirm the homogeneity of the geophysical response. This homogeneous response was not surprising, considering that laboratory tests concucted on core and drill cuttings samples have indicated that the alluvial deposits penetrated by Science Trench Boreholes were relatively homogenous with respect to mineralogical, material, and hydrologic properties (Section 3.0). In addition, the fact that the logs in alluvium were conducted inside at least one steel casing further limited their potential usefulness. Steel casing dampens the response of most logs and greatly limits the usefulness of logging calibration curves which are usually generated in uncased boreholes. It should be noted that unstable borehole wall conditions in the alluvium required that all logs be conducted inside the casing. 
Several logs provided borehole condition information that was helpful in designing plans for instrumenting and stemming the vadose zone portion of each Pilot Well (Section 2.5). Both neutron and density logs identified regions of each borehole that were "washed out" (regions where borehole diameters became much larger than bit diameter). Density logs (including both short and long source/detector spacing) decreased significantly in these "washed out" regions, indicating the presence of void spaces behind the casing. Neutron logs, which are also dependent on formation (and casing) density, responded to these same "washed out" regions. As expected, the short neutron source/detector spacing logs (NEUT[S]) responded similarly to density logs and the long neutron source/detector spacing logs (NEUT[F]) responded in the opposite direction. Specific intervals of boreholes where "washed out" regions were significant included from 112.8 to $173.7 \mathrm{~m}$ (370 to $570 \mathrm{ft}$ ) and from 213.4 to $231.6 \mathrm{~m}(700$ to $760 \mathrm{ft})$ in UESPW-1, from 121.9 to $167.6 \mathrm{~m}$ (400 to $550 \mathrm{ft})$ and from 210.3 to $216.4 \mathrm{~m}$ (690 to $710 \mathrm{ft}$ ) in UESPW-2, and from 109.7 to $137.2 \mathrm{~m}$ (360 to $450 \mathrm{ft})$ in UESPW-3. Finally, it should be noted that problems were encountered with density log (both short and long source/detector spacings) outputs from UESPW-2 on July 20, 1992. The resulting logs should not be considered representative of either formation or borehole conditions.

An ash-flow tuff unit (Ammonia Tanks) was encountered at approximately $188.2 \mathrm{~m}$ (617.5 ft) in UESPW-3. When logs were conducted in the lower portion of this borehole on November 18, 1992, the 219.1- $\mathrm{mm}$ O.D. casing extended to a depth of approximately $213.4 \mathrm{~m}$ (700 ft). The natural gamma log results show a gradual increase in counts with depth in both the cased (188.2 to $213.4 \mathrm{~m}$ [617.5 to $700 \mathrm{ft}]$ ) and uncased regions (213.4 to $291.0 \mathrm{~m}$ [ 700 to $955 \mathrm{ft}]$ ) of the borehole. This response may be due to changes in lithology and/or degree of welding (Section 3.1.2).

While the natural gamma log shows a significant response in the uncased tuff region of UESPW-3, neutron and density logs show little variability in this region of borehole down to a depth of approximately $3.0 \mathrm{~m}$ (10 ft) above the water table (approximately $270.7 \mathrm{~m}$ [888 ft]). This indicates that depth profiles of moisture contents and densities were relatively constant until approximately $3.0 \mathrm{~m}$ above the water table where the logs exhibit a response indicative of increasing water contents.

Similar responses to increasing water contents beginning approximately $3.0 \mathrm{~m}$ above the water table were noted in neutron and density logs in alluvium for boreholes UESPW-1 and UESPW-2. These responses are consistent with drill cuttings and core water content data.

\subsubsection{Summary of Borehole Deviation Logs}

Borehole deviation logs were conducted after 73.0-mm (2.875-in) O.D. monitoring well casing was installed in each well. This log collects both angle (inclinometer) and direction (gyro) data to correct actual logging cable length to true vertical depth. True vertical depth is required to obtain accurate water table elevation measurements. 
The borehole deviation log data for UESPW-1, UESPW-2, and UESPW-3 are in Appendices F.3.4, F.3.7, and F.3.10, respectively, as well as a plan view graph of borehole deviation. An error analysis has been conducted on individual depth correction measurements and error bars have been developed for the total depth correction. This information is discussed in detail in relation to water table elevation measurements in Section 4.5.1 and Appendix F.5.1.

\subsection{In Sitv Air Permeability Testing}

Air permeability tests are being performed to address some of the data requirements for modeling the transport of water vapor, hazardous gases, and radioactive gases in the unsaturated alluvial materials found throughout Area 5 . In situ measurements provide estimates of both the magnitude and variability of the permeability of the gases of concern, as well as a means of determining if laboratory-measured saturated hydraulic conductivities from $76.2-\mathrm{mm}$ (3-in) by $76.2-\mathrm{mm}$ core samples are representative of permeabilities measured on a field scale.

In situ air permeability measurements in UESPW-1 using two different air injection methods are described in the following. Air permeabili.y measurements in UESPW-2 and UESPW-3 are currently in progress and will be reported in the annual Pilot Well data report.

\subsubsection{Air (Injection) Permeability Tests Below Drill Casing}

Single flow-rate air injection permeability measurements were made during the drilling of UESPW-1 by using the steel drill casing as an air conduit. These injection tests were conducted at both 8.4-m (27.5-ft) and 45.7-m (150-ft) depths, however, experimental difficulties prevented collection of data suitable for analysis from the $45.7-\mathrm{m}$ depth test.

Prior to beginning these tests, the drill rods, air-percussion hammer, and drill bits were removed from the borehole. Air was then injected into the approximately $304.8-\mathrm{mm}$ (12-in) diameter by $152.4-\mathrm{mm}$ (6-in) long uncased cylindrical cavity. This cavity is created by the pilot and reamer bits during drilling and located at the base of the outer $273.0-\mathrm{mm}$ (10.75-in) O.D. drill casing. It was assumed that the annular space between the drill casing and the formation did not provide a preferential flow path. Air pressures were monitored in two $25.4-\mathrm{mm}$ (1.0-in) O.D. by $12.7-\mathrm{mm}(0.5-\mathrm{in})$ I.D. monitoring holes installed using the Geoprobe hydraulic punch at horizontal distances of 4.6 and $9.1 \mathrm{~m}$ (15 and $30 \mathrm{ft}$ ) from UESPW-1. The Geoprobe holes were installed to a depth of $9.1 \mathrm{~m}$.

Data were analyzed using the extended Darcy equation. The air permeability for the injection test at 8.4-in was found to be $7.8 \times 10^{-12} \mathrm{~m}^{2}(7.8 \mathrm{D})$ using data from both the 4.6-m and $9.1-\mathrm{m}$ Geoprobe holes, which demonstrated good experimental reproducibility using this method. This value agrees well with field measurements of air permeability of 
NTS alluvium reported in the literature (Pasternak and McMullen, 1970; Morris et al., 1971; Snoeberger et al., 1974; Rozsa et al., 1975).

These tests were not repeated at additional depths in UESPW-1 or the other two Pilot Wells for several reasons. The expense of the drill rig for standby-time while conducting these tests, the additional disturbance of in situ gas composition and possibly the hydrologic conditions of the formation by the injection of large volumes of air into the formation, and the numerous experimental difficulties encountered during in situ testing were key reasons for the decision not to repeat testing.

\subsubsection{Post Drilling Air (Injection) Permeability Testing}

Injection tests were conducted in the type B instrument stations which consisted of one 20.7- $\mathrm{mm}(0.814-\mathrm{in})$ I.D. nylon injection tube and one 4.6- $\mathrm{mm}(0.18-\mathrm{in})$ I.D. stainless steel

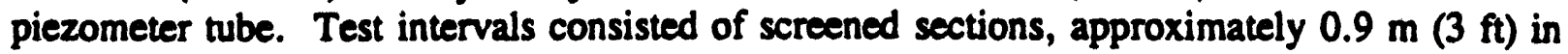
height filled with coarse sand. The annular space above and below the screened section was sealed with a low-permeability mixture of bentonite and sand. The depths and dimensions of the air permeability stations in the Pilot Wells are listed in Appendix F.4.1. The majority of the test intervals were located in unsaturated alluvial deposits. Laboratory analysis of cores taken during drilling indicated that the hydraulic properties of these deposits were remarkably constant with depth. The only interval not in alluvial deposits was the $210 \mathrm{~m}$ (689 ft) testing interval in UESPW-3 located in a rhylotic ash-flow tuff unit (Section 3.1.2).

The tests consisted of injecting air into the screened interval (through the $20.7-\mathrm{mm}$ I.D. nylon tube) at a constant flow-rate until the pressure in the interval (measured at the ground surface in the stainless steel piezometer tube) reached a steady value (less than $0.7 \mathrm{kPa}$ [0.1 $\left.\mathrm{lb} / \mathrm{in}^{2}\right]$ change in $10 \mathrm{~min}$ ). In most cases this occurred within $15 \mathrm{~min}$. The injection flow-rate was then inoreased and a new steady-state pressure was obtained. A minimum of four steady-state pressures corresponding to four constant flow-rates were measured for each screened interval.

In UE5PW-1, tests were successfully conducted in the test intervals at $45.7,73.2$, and $107 \mathrm{~m}$ $(150,240$, and $350 \mathrm{ft})$ depths. Application of $552 \mathrm{kPa}\left(80 \mathrm{lb} / \mathrm{in}^{2}\right)$ to the interval at $183 \mathrm{~m}$ $(600 \mathrm{ft})$ resulted in a flow-rate of only $3.4 \mathrm{~m}^{3} / \mathrm{hr}(2 \mathrm{ft} / \mathrm{min})$ with no detectable pressure increase in the interval. The lack of flow and pressure response indicated that this injection line possibly became plugged during stemming and no further testing was conducted in this interval. In UESPW-2, tests were completed in the intervals at $45.7,76.2,122$, and $183 \mathrm{~m}$ $(150,250,400$, and $600 \mathrm{ft})$. In UESPW-3, tests were successfully completed in the intervals at $76.2,107$, and $210 \mathrm{~m}(250,350$, and $689 \mathrm{ft})$. Flow and pressure testing from the $168 \mathrm{~m}$ (550 ft) testing interval in UESPW-3 resulted in an atypically low permeability estimate that may have been due to contamination of the testing interval with stemming material. The test data are summarized in Appendix F.4.2. Test results were analyzed using a form of Darcy's 
law modified for compressible flow. If inertial effects were observed an integrated form of the Forchheimer equation was used (Katz et al., 1959).

The estimates of apparent permeability and inertial coefficients obtained from the Pilot Wells are in Appendix F.4.3 with the permeabilities ranging from $0.9 \times 10^{-12}$ to $47.0 \times 10^{-12} \mathrm{~m}^{2}$ $(0.9$ to $47 \mathrm{D})$. These values are consistent with both the permeability value measured in the drill casing described in Section 4.4.1 and with the previous NTS studies also cited above.

Permeabilities to water were determined on 60 core samples. The mean value of liquid permeability for these samples was $1.1 \times 10^{-12} \mathrm{~m}^{2}(1.1 \mathrm{D})$. The mean value for air permeability for the tested intervals, excluding the test in the tuff unit, was $12 \times 10^{-12} \mathrm{~m}^{2}$ (12 D). Permeabilities to air and water differed by (approximately) an order of magnitude. This was expected; permeability of geologic materials to air generally exceeds permeability to water, due to water-matrix materials interactions. Air permeability was determined in the laboratory on three unfractured core samples of the tuff. The mean permeability for these laboratory measurements was $4.3 \times 10^{-13} \mathrm{~m}^{2}(4.3 \mathrm{D})$. The air permeability obtained from injection tests in the tuff unit at $210 \mathrm{~m}(689 \mathrm{ft})$ in UESPW-3 was $18 \times 10^{-12} \mathrm{~m}^{2}(18 \mathrm{D})$. This larger value from the in situ tests suggests that the tuff unit is fractured at this depth.

Because the stress induced in the formation by an air injection test is rapidly dissipated, the air permeability stations in the Pilot Wells can be tested repeatedly. Since the permeability is a strong, highly nonlinear, function of water content, these tests could potentially be used to monitor changes in water content. For example, an observed decrease in permeability would suggest an increase in water content.

\subsection{Upper Aquifer Hydraulic Parameter Testing}

\subsubsection{Water Table Elevations and Gradient}

The three Pilot Wells, drilled in the southeast and northeast alluvial aquifer and the northwest tuff aquifer, have defined an almost horizontal water table below the Area 5 RWMS. Water level measurements were made from the top of the monitoring well casing in each Pilot Well by REECo SPS personnel using a Solonist E-tape. The recorded depth and calculated water level elevations (uncorrected for borehole deviation) are presented in Table 4.2. These measurements indicate little variation in the water table and the changes that are seen are probably within the precision and accuracy of the instrument. U.S. Geological Survey (USGS) personnel also took water level measurements in each Pilot Well with a Solonist E-tape and are presented in Table 4.2. These measurements by the USGS were taken with an older E-tape and were slightly deeper than the REECo measurements taken on the same day. The USGS also used a calibrated steel tape (accurate to $\pm 0.003 \mathrm{~m}[ \pm 0.01 \mathrm{ft}]$ ) to measure the depth to water.

A borehole geophysical deviation survey log was run in each borehole (Section 4.3 .3 ) to attempt to correct for borehole deviations from a vertical straight line. It should be 
Table 4.2 Uncorrected water table elevation data.

\begin{tabular}{|c|c|c|c|c|c|c|}
\hline \multirow[b]{2}{*}{ Date } & \multicolumn{3}{|c|}{ Depth to water from TOC' $m$ (i) } & \multicolumn{3}{|c|}{ Water table elevation m (ft) } \\
\hline & UESPW-1 & UESPW-2 & UESPW-3 & UESPW-1 & UESPW-2 & UESPW-3 \\
\hline $2-28-93$ & $235.702(773.30)$ & $256.632(841.97)$ & $271.778(891.66)$ & $733.669(2407.05)$ & $733.486(2406.45)$ & $733.443(2406.31)$ \\
\hline $3-02-23$ & 235.677 (7773.22) & $256.672(842.10)$ & 271.805 (891.75) & 733.693 (2407.13) & $733.446(2406.32)$ & $733.416(2406.22)$ \\
\hline $3-02-93^{2}$ & $235.729(773.39)$ & $256.742(842.33)$ & 271.775 (891.65) & 733.641 (2406.96) & $733.376(2406.09)$ & $733.446(2406.32)$ \\
\hline 3-04-93 & $235.726(773.38)$ & $256.739(842.32)$ & $271.802(891.74)$ & 733.644 (2406.97) & $733.379(2406.10)$ & $733.419(2406.23)$ \\
\hline $3-08-93$ & $235.613(773.01)$ & $256.626(841.95)$ & $271.711(891.44)$ & $733.757(2407.34)$ & $733.492(2406.47)$ & $733.510(2406.53)$ \\
\hline 3-22-93 & $235.635(773.08)$ & $256.587(841.82)$ & $271.703(891.43)$ & $733.736(2407.27)$ & $733.532(2406.60)$ & $733.513(2406.54)$ \\
\hline 3-23-93 & $235.607(772.99)$ & $256.681(842.13)$ & $271.699(891.40)$ & $733.763(2407.36)$ & $733.437(2406.29)$ & $733.523(2406.57)$ \\
\hline $3-24-93$ & $235.610(773.00)$ & 256.565 (841.75) & $271.708(891.43)$ & 733.760 (2407.35) & $733.553(2406.67)$ & $733.513(2406.54)$ \\
\hline $3-25-93$ & $235.607(772.99)$ & $256.556(241.72)$ & $271.708(891.43)$ & $733.763(2407.36)$ & $733.562(2406.70)$ & $733.513(2406.54)$ \\
\hline $3-29-93$ & $235.671(773.20)$ & $256.559(841.73)$ & 271.747 (891.56) & $733.699(2407.15)$ & $733.559(2406.69)$ & $733.474(2406.41)$ \\
\hline $3-29-93^{2}$ & 235.711 (773.33) & $256.629(841.96)$ & $271.738(891.53)$ & 733.660 (2407.02) & $733.489(2406.46)$ & $733.483(2406.44)$ \\
\hline 3-29-93' & $235.641(773.10)$ & $256.535(841.65)$ & $271.683(891.35)$ & $733.730(2407.25)$ & $733.583(2406.77)$ & $733.538(2406.62)$ \\
\hline 3-29-933 & $235.609(773.06)$ & $256.541(841.67)$ & $271.693(891.38)$ & $733.742(2407.29)$ & $733.577(2406.75)$ & 733.529 (2406.59) \\
\hline $3-30-93$ & $235.705(773.31)$ & $256.636(841.98)$ & $271.772(891.64)$ & $733.666(2407.04)$ & $733.483(2406.44)$ & $733.449(2406.33)$ \\
\hline 4-01-93 & $235.620(773.03)$ & $256.578(841.79)$ & $271.708(891.43)$ & 733.751 (2407.32) & 733.541 (2406.63) & $733.513(2406.54)$ \\
\hline $4-05-93$ & 235.589 (772.93) & $256.553(841.71)$ & $271.693(891.38)$ & $733.762(2407.42)$ & 733.565 (2406.71) & $733.529(2406.59)$ \\
\hline $4-06-93$ & $235.671(773.20)$ & $256.611(841.90)$ & 271.769 (891.63) & $733.699(2407.15)$ & 733.507 (2406.52) & $733.452(2406.34)$ \\
\hline
\end{tabular}

'TOC: Top of monitor well casing

'USGS E-tape measurements

YUSGS Calibrated stoel lupe measurements 
emphasized that the error in the deviation logs may be equal to or greater than the differences in uncorrected water table elevations. For example, data from the manufacturer and operator of the deviation tool (Century Geophysics Corp.) indicate that the error in the corrected depth provided by this tool is $\pm 0.15 \mathrm{~m}$ ( $\pm 0.5 \mathrm{ft})$. This error is as large as the difference observed between water table elevations. In addition, estimated errors arising from the use of a water level measurement tape are on the order of $\pm 0.03 \mathrm{~m}( \pm 0.1 \mathrm{ft})$, and the error associated with surveying casing elevations is probably somewhat less. Because of these uncertainties, it is only reasonable to conclude that differences in water table elevations are within the error of measurement. The correction factors for UESPW-1, UE5PW-2, and UESPW-3 are $-0.08,-0.21$, and $-0.02 \mathrm{~m}(-0.27,-0.68$, and $-0.06 \mathrm{ft})$, respectively. The elevations and coordinates of the top of each monitoring well casing were surveyed by REECo Engineering and are listed in Table 2.2.

Efforts are continuing to identify methods and equipment that more accurately estimate borehole deviation, and therefore more accurately estimate water table elevations. In addition, water level measurements are currently being collected on a weekly basis to obtain data on the natural variations in water levels and to better estimate the precision of water level measurement methods.

Various methods were employed to determine the shape of the water table below the Area 5 RWMS utilizing available water table elevations. The shape of the water table must be known to estimate the gradient and the direction of flow. These methods include a planar approximation and a statistical analysis that includes uncertainties in measurements (Appendix F.5.1). The conclusions reached from these analyses are similar; that the water table below the Area 5 RWMS is approximately horizontal. Without elevation differences, the gradient is nearly zero and there will be essentially no horizontal movement in the uppermost aquifer.

\subsubsection{Hydraulic Conductivity Recovery Tests}

In situ hydraulic conductivity tests were conducted in the Pilot Wells following standard slug test techniques (Table 2.1). Standard single well pump test methods that would provide more reliable estimates of the uppermost aquifer hydraulic properties could not be conducted in the Pilot Wells primarily because of the small diameter of the monitoring well casing and the great depth to water. The high-volume, multi-stage pumps required to stress the permeable, relatively coarse-grained uppermost aquifer, approximately $243.8 \mathrm{~m}(800 \mathrm{ft})$ below the ground surface, are not available to fit in the $63.5-\mathrm{mm}(2.5-\mathrm{in})$ I.D. monitoring well casing. Pumps which do fit in this casing and are capable of lifting at least $243.8 \mathrm{~m}$ (e.g., Bennett sample pump) are, without exception, not capable of the high flow-rates required to create drawdowns in the alluvial aquifer.

Following weli development (Section 2.6), in situ hydraulic conductivity tests (ASTM D 4044-91, 1992) were conducted in the screened interval of each Pilot Well by 
submerging a $38.1-\mathrm{mm}$ (1.5-in) O.D. by $6.1-\mathrm{m}$ (20-ft) long mechanical slug, allowing the water level to stabilize, and then rapidly removing the mechanical slug and monitoring the recovery of the aquifer vs. time. Hydraulic conductivity values were calculated from a plot of the recovery data (log of water level) vs. time. Data were analyzed assuming the aquifer was partially penetrated, unconfined (or leaky confined), and incompressible. The average conductivities for UESPW-1, UESPW-2, and UESPW-3 were $1.3 \times 10^{-3}, 3.4 \times 10^{-4}$, and $1.4 \times 10^{-3} \mathrm{~cm} / \mathrm{s}(1.8,0.5$, and $2.0 \mathrm{in} / \mathrm{hr})$, respectively. The results of the individual slug test are presented in Appendix F.5.2. The mean in situ hydraulic conductivity values calculated for the upper portion of the alluvial aquifer in UESPW-1 and UESPW-2 were nearly identical to the mean hydraulic conductivities calculated from core samples collected over the entire depth of each borehole. The mean in situ hydraulic conductivity calculated for the upper portion of the tuff aquifer is within the range of hydraulic conductivities previously measured on bedded tuff core samples collected at the NTS (Winograd and Thordarson, 1975).

In addition, a separate slug test was conducted during the final stages of drilling UESPW-1 in an uncased portion of the borehole (occupied by the drill and reamer bits during drilling) located directly below the casing. Prior to the test, the drill string was removed from the borehole, leaving an uncased cylindrical cavity measuring approximately $304.8-\mathrm{mm}$ (12-in) diameter by $152.4-\mathrm{mm}(6-\mathrm{in})$ length available for testing. The mechanical slug was rapidly lowered into the water, and the aquifer recovery rate was monitored. The same assumptions, as described above, were made in analyzing the recovery data. The hydraulic conductivity value calculated from these data $\left(5 \times 10^{-1} \mathrm{~cm} / \mathrm{s}\left[7 \times 10^{-5} \mathrm{in} / \mathrm{hr}\right]\right)$ is many orders of magnitude less than mean conductivities calculated by the recovery test method described above and mean values from laboratory tests on core samples. The reason for the differences in these values may be that the exposed walls of the formation in the small cylindrical cavity may have been smeared with fine materials during drilling, which in tum greatly reduced the hydraulic conductivity.

Alternatively, the slug tests in the $63.5-\mathrm{mm}$ monitoring well casing described previously, did not stress the aquifer enough to provide recovery data representative of the formation. However, comparisons of saturated hydraulic conductivity from core samples (Section 3.3.1) indicate that this slug test was anomalous.

\subsection{Neutron Logging Calibration Boreholes}

Three shallow boreholes for neutron-moisture meter calibration were drilled and cased with the three different diameter CAU drilling systems being used in the Pilot Well Project. These boreholes were installed during the drilling of UESPW-2 when the drill casing became stuck and the drilling operations could not continue for approximately a week until equipment could be brought on site to free the casing. Rather than put the drilling rig and crew on "standby time", it was decided to drill and sample several 12.2-m (40-ft) deep boreholes 


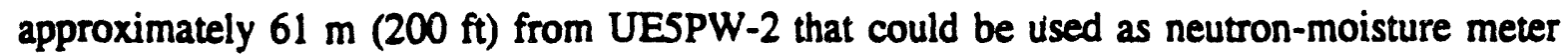
(and other borehole geophysical logging tool) calibration holes.

Neutron-moisture meter logging through large diameter steel casing has been proven to be a valuable method of monitoring changes in water content in alluvium at the NTS (Tyler, 1986). It was determined that this type of logging would prove useful during and after drilling future vadose zone exploratory and monitoring wells with the CAU drilling system at the Area 5 RWMS. REECo SPS currently operates a CPN Model 503DR neutronmoisture meter for vadose zone monitoring of a mixed-waste storage facility, and the meter would be readily available for logging in CAU drilling system boreholes.

The calibration boreholes, UESPW-2A, UESPW-2B, and UESPW-2C, were drilled with 219.1-mm (8.625-in) O.D., 193.7-mm (7.625-in) O.D., and 273.0-mm (10.75-in) O.D. CAU drilling system casing, respectively. The threaded connections on these casings had been damaged slightly during previous drilling activities and were not suited for deep drilling use making these casings ideal for use in these shallow calibration holes.

A shallow trench was excavated and filled with water for several days to create a wetting front with depth. The boreholes were then drilled in the trench with core and drill cuttings samples collected. The geologic samples collected from these boreholes were subjected to the same laboratory tests as samples from the Pilot Wells. Neutron-moisture logs were conducted immediately after completing each cased borehole, and periodically since completion. Depth profiles of neutron-moisture meter counts measured just after borehole completion are correlated with the volumetric water content from core samples to obtain calibration curves (relating counts to water content) for these different sized casings. Appendix $\mathrm{G}$ contains all pertinent drilling, sampling, laboratory results, neutron-moisture meter data, and calibrations for these shallow calibration holes. 


\section{S.0 UPPER AQUIFER WATER QUALITY}

\subsection{RCRA Groundwater Sampling and Analysis}

A primary objective of the Pilot Well Project is to characterize the water quality of the uppermost aquifer under the Area 5 RWMS. With this in mind, a test plan was developed consistent with the detection and monitoring requirements of 40 CFR 265, Subpart F (Table 2.1), and initial samples were collected from UESPW-1 and analyzed. Based on this initial sampling and analysis activity, a standard operating procedure was developed (draft procedure presently under REECo review) which will be used to implement a groundwater characterization program at all three Pilot Wells. Results from this site characterization program will be the subject of future groundwater characterization reports. Field and laboratory testing results from the initial samples collected at UESPW-1 are presented and discussed below.

Groundwater samples were collected with a submersible stainless-steel double-action piston pump operating at a flow-rate of approximately $2 \mathrm{~L} / \mathrm{min}(0.5 \mathrm{gal} / \mathrm{min})$. Three wellbore volumes were purged prior to sample collection. Water temperature, $\mathrm{pH}$, specific conductance and redox potential were monitored during purging and sample collection. Standard QA procedures (Table 2.1) governing sample collection and analysis (e.g., standard containers, preservatives, filtration, holding times, blanks, replicates, chain-of-custody, accuracy, and precision) were followed. Sample collection methods and a brief discussion of these results are described in more detail in Appendix H.1.

The chemical parameters analyzed and methods used are summarized in Table 5.1. All analyses were performed by the REECo Analytical Services Department (ASD), with the exception of total organic carbon (TOC), total organic halogens (TOX), and herbicides which were sent to subcontracted testing laboratories.

In summary, the concentrations of all parameters, including those required to assess the suitability of groundwater as drinking water, as well as parameters to establish groundwater quality, are below applicable standards. The only exception was manganese and possibly chromium. Manganese exceeds the state of Nevada secondary standards for drinking water. Chromium was not detected but the detection limit was slightly higher than the state of Nevada primary standards for drinking water. Moreover, the mean value of the $\mathrm{pH}(8.13)$ and specific conductance $(0.0389 \mathrm{~S} / \mathrm{m}[0.389 \mathrm{mmhos} / \mathrm{cm}])$ were indicative of good quality drinking water. Finally, organic contamination indicator parameters (TOC and TOX) were below or near detection levels. In conclusion, the initial sampling and analyses of groundwater from UESPW-1 indicate that it is of high quality and meets all standards concerning hazardous and radioactive constituents. 
Table 5.1 Testing laboratories, chemical parameters, and analytical methods.

\begin{tabular}{|c|c|c|}
\hline Laboratory & Sample Parameters & Method \\
\hline REECo ASD & Volatile Organics & $8240^{1}$ \\
\hline DataChem Laboratories & Total Organic Halogen & $9020^{1}$ \\
\hline DataChem Laboratories & Total Organic Carbon & $9060^{\prime}$ \\
\hline REECo ASD & Oil and Grease & $413.2^{2}$ \\
\hline REECo ASD & $\begin{array}{l}\text { Pesticides/PCBs: Toxaphene, } \\
\text { Lindane, Methoxychlor, Endrin }\end{array}$ & $8080^{\prime}$ \\
\hline DataChem Laboratories & Herbicides & $8150^{\prime}$ \\
\hline REECo ASD & Semivolatile Organics & $8270^{\prime}$ \\
\hline REECo ASD & $\begin{array}{l}\text { Total Metals: As, Ba, Cd, Cr, Fe, } \\
\mathrm{Hg}, \mathrm{Mn}, \mathrm{Na}, \mathrm{Pb}, \mathrm{Se}\end{array}$ & $6010^{1}$ \\
\hline REECo ASD & Total Silver & $6010^{1}$ \\
\hline REECo ASD & Cyanide & $335.2^{2}$ \\
\hline REECo ASD & Chloride, Sulfate, Fluoride, Nitrate & $300^{2}$ \\
\hline REECo ASD & $\begin{array}{l}\text { Total Gross Alpha/Beta } \\
\text { Gamma Spectroscopy }\end{array}$ & AABAB.D.04.303 \\
\hline REECo ASD & Strontium & AABAB.D.04.403 \\
\hline REECo ASD & Technetium & AAHCD.D. $04.40^{3}$ \\
\hline REECo ASD & Total Uranium & AABAB.D.04.20 \\
\hline REECo ASD & ${ }^{131}$ Iodine & AABAB.D.04.553 \\
\hline REECo ASD & 205.209 .200 Plutonium & AABAB.D.04.10 \\
\hline REECo ASD & 200.20 Radium & AAHCD.D.04.07 \\
\hline REECo ASD & $\begin{array}{l}\text { Dissolved Metals: As, } \mathrm{Ba}, \mathrm{Cd}, \mathrm{Cr} \text {, } \\
\mathrm{Fe}, \mathrm{Hg}, \mathrm{Mn}, \mathrm{Na}, \mathrm{Pb}, \mathrm{Se}\end{array}$ & $6010^{1}$ \\
\hline REECo ASD & Dissolved Silver & $6010^{1}$ \\
\hline REECo ASD & $\begin{array}{l}\text { Dissolved Gross Alpha/Beta } \\
\text { Gamma Spectroscopy }\end{array}$ & AABAB.D.04.303 \\
\hline REECo ASD & Total Dissolved Solids & $160.1^{2}$ \\
\hline REECo ASD & Tritium & $\begin{array}{l}\text { AABAB.D. } 04.70^{3} \\
\text { (Electrolytic Enrichment) }\end{array}$ \\
\hline
\end{tabular}




\subsection{Preliminary Comparison of General Water Chemistry}

A preliminary general chemical analysis of groundwater samples collected from the Pilot Wells and several existing wells in the northem part of Frenchman Flat was conducted by DRI. The general chemical parameters analyzed included pH, conductivity, major cations, anions, and several other indicator parameters. The purpose of this activity was to compare the general chemistries of the Pilot Wells and surrounding wells, to begin to characterize the variability in the water chemistry of the uppermost alluvial aquifer, and to obtain geochemical information relating to the possible source(s) of these waters and therefore possible directions of flow. Details of the methods, used together with the results from this preliminary general water chemistry survey, are presented in Appendix H.2 with a brief summary presented below.

It should be noted that the results discussed below are preliminary in nature. For example, groundwater samples were collected from undeveloped Pilot Wells and the results may not be representative of in situ water. Samples from a number of the surrounding wells were collected from screened intervals that were significantly below the uppermost zone sampled in the Pilot Wells. Additional sampling and analyses are planned in the near future for the recently developed Pilot Wells. In addition, future samples will be collected (where possible) in all wells at the same depth below the water table $(e .8 ., 15.2 \mathrm{~m}$ [50 ft]). Finally, the same sampling method (e.g., piston pump) will be used where possible.

Water quality data from UESPW-1 and UESPW-3, UESn and six nearby wells, all located in the Frenchman Flat area, were collected and analyzed by DRI. Water samples from the two Pilot Wells and well UESn were collected in January and February of 1993 and submitted for gross chemical analysis, stable isotope analysis, and enriched tritium counting. Water chemistry data for the six nearby wells were obtained from DRI archived data from past analyses. The conclusions are:

-

.

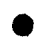

○

The gross chemical analyses for wells UESPW-1 and UESPW-3 are very similar.

These Pilot Well waters can be characterized as sodium bicarbonate waters with a total dissolved solid content of approximately $360 \mathrm{mg} / \mathrm{L}$.

All of the samples from the Pilot Wells were saturated with respect to calcite, dolomite and several forms of silica and calcium-magnesium silicates.

Pilot Well water chemistry was most similar to that of Water Well 4, located to the northwest, but presumably hydraulically separated from the Pilot Wells by the Cane Springs Fault. 
Analysis of the data with Stiff diagrams and tri-linear plots reveals that the Pilot Wells are higher in calcium and magnesium, relative to sodium, than most other wells.

The DRI report concluded that the groundwater from the Pilot Well area has had more contact with carbonate material than water sampled elsewhere in Frenchman Flat. The report states that this is most likely to have occurred by percolation srough alluvium derived from carbonate rocks; from the CP Hills area north of Water Well 4 and from Nye Canyon located east of the Area 5 RWMS. Further, they report that water samples from well UESn, located in the west-central part of Frenchman Flat were relatively calcium poor while still saturated with calcite. These findings were interpreted to mean that water from this well originated in volcanic terrain found to the west or alternatively that the water originated from downward percolation through carbonate poor alluvial material in this area. 


\subsection{PRELIMINARY VADOSE ZONE MONITORING DATA}

The installation and stemming of thermistors, air pressure transmitters, and thermocouple psychrometers at type A instrument stations have been previously described in Section 2.5.1. Calibration procedures together with preliminary data collected to date will be briefly described in the following. Delays in electric power distribution to each Pilot Well site has limited the data collection activities, but portable data loggers/controllers demonstrated that the instruments are in working order. Continuous monitoring of the vadose zone is expected to begin in the near future when permanent electrical power has been supplied to each Pilot Well and computer-controlled data acquisition can be used. These monitoring data will be reported in the annual Pilot Well data report.

\subsection{Temperature Profile Data}

The thermistors were calibrated for each mode of operation (resistance and voltage drop) following the methods developed by the USGS (J. Rousseau, USGS, 1993, personal communication) for the Yucca Mountain Project (USGS, 1990). These methods were made available through a Department of Energy technology transfer program. Summary calibration data are presented in Appendix I.1.

To date, thermistor temperatures (voltage drop method) have been measured at type A instrument stations in all three Pilot Wells. Temperature data was collected for Pilot Wells UESPW-1 and UESPW-3 in mid-April, 1993. Due to instrumentation problems data were not collected for UESPW-2 until mid July, 1993. Preliminary temperature profile data are plotted in Figure 6.1 and tabular temperature data are presented in Appendix 1.2. The high temperature measured at the $30.5-\mathrm{m}(100-\mathrm{ft})$ level in UESPW-3 is not plotted because it is probably an anomaly resulting from heat being generated from the nearby cement plug (Section 2.5.2) which had been recently poured. A similar anomaly was detected at the $30.5 \mathrm{~m}(100-\mathrm{ft})$ level in UESPW-2, and was likewise is not plotted in this data. Thermal gradients of $2.06^{\circ} \mathrm{C} / 304.8 \mathrm{~m}(1,000 \mathrm{ft})$ in UESPW- $1,4.30^{\circ} \mathrm{C} / 304.8 \mathrm{~m}$ in UESPW-2 and $3.83^{\circ} \mathrm{C} / 304.8 \mathrm{~m}$ in UESPW-3, have been calculated from these temperature profiles. Additional monitoring data are needed to determine if instruinent stations are in thermal equilibrium with the formation and the differences in thermal gradients between boreholes are significant.

\subsection{Formation Air Pressure Profile Data}

Factory calibrations supplied with Druck PTX pressure transmitters are summarized in Appendix 1.3 for the instruments installed in the three Pilot Wells. These pressure transmitters were also independently calibrated by the Physical Standards and Calibration Laboratory operated by REECo. However, problems identified with the calibration methods used by REECo have prevented the use of these calibration data. 


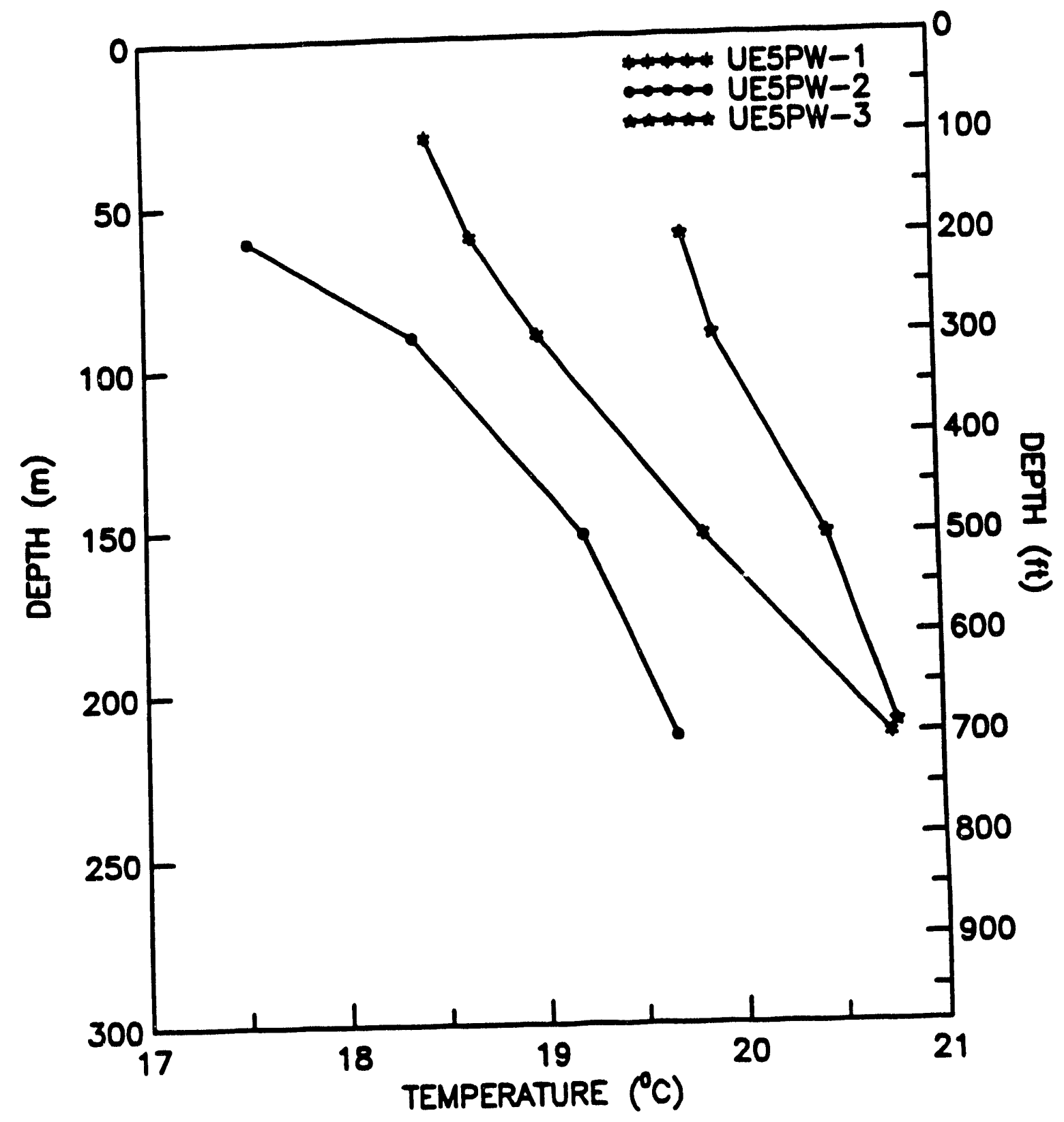

Figure 6.1 Depth profiles of in situ temperatures from the Pilot Wells. 
Preliminary formation air pressure measurements made at type B instrument stations in UESPW-1 and UESPW-3 are summarized in Appendix 1.4. It is difficult to determine if these measurements accurately reflect formation air pressures without monitoring these instruments as well as atmospheric air pressure over a period of time to observe at least several high and low pressure waves. However, these preliminary data indicate that nearly all transmitters are operational and produce pressure readings that appear to be within a reasonable range.

\subsection{Water Potential Profile Data}

Thermocouple psychrometer design, calibration equipment and methods, and field data acquisition systems developed by the USGS for the Yucca Mountain Project (USGS, 1993) were adopted for the Pilot Well Project. The USGS (J. Rousseau, USGS, 1993, personal communication) shared both calibration equipment and expertise. Tables of the calibration coefficients are in Appendix I.5.

A portable rack-mounted data acquisition system was built to perform baseline monitoring of the in situ thermocouple psychrometers. Psychrometer data are currently collected monthly until permanent electrical power is supplied and computer-controlled data acquisition can be used for continuous monitoring. Preliminary in situ psychrometer data obtained are presented in Appendix 1.6 and Figure 6.2. Water potential profile data (distance is positive downwards) show a positive gradient (upward flow) in the upper $61 \mathrm{~m}$ ( $200 \mathrm{ft}$ ). At deeper depths the potential gradient becomes nearly zero and constant. These preliminary in situ psychrometer data compare favorably with the water potentials measured in the laboratory for core samples (Section 3.4.2). 


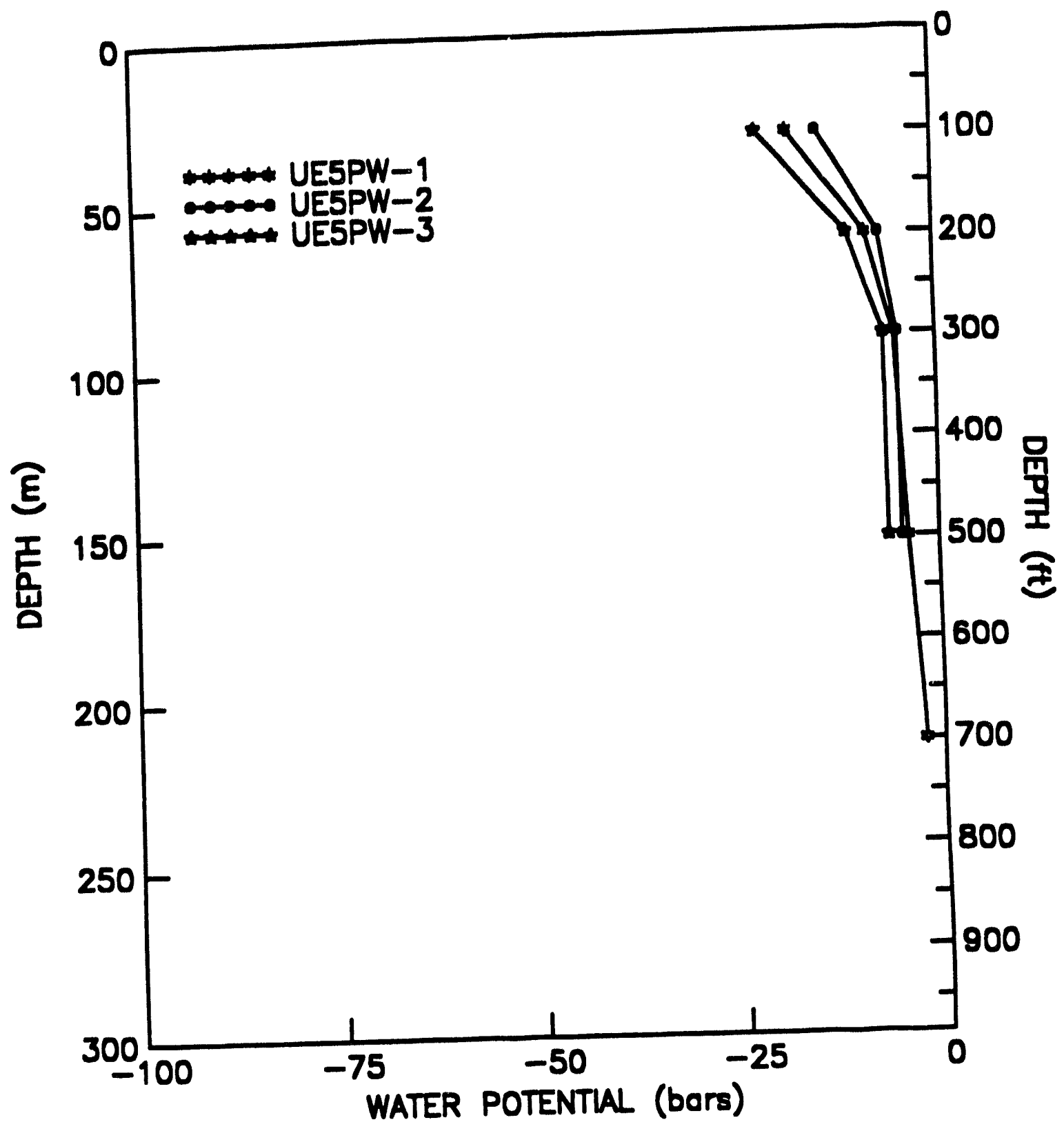

Figure 6.2 Depth profiles of in situ pschyometer data from the Pilot Wells. 


\subsection{SUMMARY}

Three Pilot Wells have been drilled and completed to the uppermost aquifer in the vicinity of the Area 5 RWMS to meet data needs mandated by regulatory requirements applicable to the disposal of low-level, mixed, and high-specific-activity waste at this site. This series of boreholes was specifically designed to characterize the hydrogeology of the thick vadose zone and to help define the water quality and hydraulic characteristics of the uppermost aquife.

This report has described the methods and results of Pilot Well borehole drilling, geologic sample collection, field geologic descriptions, laboratory testing of geologic samples, well and vadose zone monitoring system completion, geophysical logging and other in situ testing, well development and in situ aquifer testing, preliminary groundwater sampling and analyses, and preliminary vadose zone monitoring activities. These results (data) are required to understand and model flow and transport processes both in the vadose zone and uppermost aquifer. This report has provided only qualitative analyses and preliminary interpretations.

Some of the important findings of this study are:

The thick alluvial deposits penetrated by each Pilot Well are lithologically homogeneous and do not contain layers of secondary carbonate.

The alluvial deposits are virtually homogeneous with respect to particle size distribution and are primarily composed of sands with some gravel and small amounts of fines.

Hydrologic properties including porosity, saturated hydraulic conductivity, moisture retention relations, and unsaturated hydraulic conductivity are typical of coarse-grained materials.

Alluvial deposits are very dry near the surface and increase only slightly with depth until a capillary fringe is reached approximately $3.0 \mathrm{~m}(10 \mathrm{ft})$ above the water table.

Water potential measurements on core samples show a large positive potential gradient (water tends to move upward, rather than downward) in the upper $30.5 \mathrm{~m}$ (100 ft) in each borehole, and a nearly zero potential gradient throughout the remaining portion of the vadose zone.

Unsaturated hydraulic conductivity data, together with water potential data, indicate that very little liquid flow is occurring (if any) throughout the thick alluvial deposits, and the direction of liquid flow is upward in the upper portion of the vadose zone. 
Because liquid water movement is virtually negligible in the upper vadose zone, vapor movement is probably the dominant mechanism of water movement in this region.

Environmental tracer measurements of chloride, bromide, sulfate, hydrogen and oxygen stable isotopes, and cosmogenic chlorine- 36 concentrations in soil water vs. depth provi strong evidence that the direction of movement for both liquid water and ipor in the upper vadose zone is upward in response to the evaporative demand of the present arid climate.

Further, environmental tracer data suggest that water which is presently in the lower vadose zone infiltrated under a more humid climate when evaporation was not an important process.

The limited data collected from the tuff units underlying the alluvium below 188.2-m (617.5-ft) depth in UESPW-3 indicate that they have properties similar to those previously reported for these units.

A variety of geophysical and in situ hydrologic and pneumatic tests support results from core and drill cuttings data which suggest that vadose zone and uppermost aquifer alluvial deposits can be considered a homogenous hydrogeologic system.

Preliminary water quality data from each Pilot Well indicate that hazardous and radioactive constituents do not exceed appropriate standards in the uppermost aquifer.

The uppermost water table gradient is nearly horizontal, with essentially a zero slope and no horizontal movement.

Vadose zone monitoring instruments and equipment, which were stemmed in place around the central monitoring well casing in each Pilot Well, are being used to make in situ measurements of important hydrologic and pneumatic parameters and to monitor changes in these parameters over time. 


\subsection{REFERENCES}

Allison, G. B. 1982. The relationship berween $10 \mathrm{O}$ and deuterium in water in sand columns undergoing evaporation. Joumal of Hydrology, Vol. 55, 163-169.

Allison, G. B. and M. W. Hughes. 1983. The use of natural tracers as indicators of soilwater movement in a temperate semi-arid region. Joumal of Hydrology, Vol. 60, 157-173.

ASTM D 2216-80. 1980. Method for laboratory determination of water (moisture) content of soil, rock, and soil-aggregate mixtures. In: 1987 Annual book of ASTM standards, Vol. 04.08, American Society for Testing and Materials, Philadelphia, PA.

ASTM D 2434-68. 1974. Test method for permeability of granular soils (constant head). In: 1987 Annual book of ASTM standards, Vol. 04.08, American Society for Testing and Materials, Philadelphia, PA.

ASTM D 2325-68. 1981. Test method for capillary-moisture relationships for coarse- and medium-textured soils by pressure-plate apparatus. In: 1987 Annual book of ASTM standards, Vol. 04.08, American Society for Testing and Materials, Philadelphia, PA.

ASTM D 422-63. 1972. Method for particle size analysis of soils. In: 1987 Annual book of ASTM standards, Vol. 04.08, American Society for Testing and Materials, Philadelphia, PA.

ASTM D 2579-85. 1990. Test method for determining total organic carbon. In: 1990 Annual book of ASTM standards, Vol. 11.02, American Society for Testing and Materials, Philadelphia, PA.

ASTM D 2488-90. 1990. Standard recommended practice for the description of soils-visual manual procedure. In: 1990 Annual book of ASTM standards, Vol. 04.08, American Society for Testing and Materials, Philadelphia, PA.

ASTM D 4044-91. 1992. Standard test method (field procedure) for instantaneous change in head (slug test) for determining hydraulic properties of aquifers. In: ASTM standards on groundwater and vadose zone investigations (PCN: 03-418192-38), American Society for Testing and Materials, Philadelphia, PA.

Blake, G. R. and K. H. Hartge. 1986. Bulk density. In: Klute, A. L. (ed), Methods of soil analysis, Part 1, Physical and mineralogical methods, 2nd Ed., American Society of Agronomy, Madison, WI, Chap. 13, pp. 363-367. 
Blinov, A. 1988. The dependence of cosmogenic isotopic production rate on solar activity and geomagnetic field variations, in secular solar and geomagnetic variations in the last 10,000 years. Stephenson, F. R. and A. W. Wolfendale (eds), Klewer Academic Publishing Co., Nordrecht, Netherlands, pp. 329-340.

Byers, F. M., Jr., W. Carr, P. Orkild, W. Quinlivan, and K. Sargent. 1976. Volcanic suites and related cauldrons of Timber-Oasis Valley caldera complex, southem Nevada. USGS Professional Paper 919.

Campbell, G. S. and G. W. Gee. 1986. Water potential measurement using the filter paper technique. In: Klute, A. L. (ed), Methods of soil analysis, Part 1, Physical and mineralogical methods, 2nd Ed., American Society of Agronomy, Madison, WI, Chap. 25, pp. 628-630.

Conrad, S. H. 1993. Using environmental tracers to estimate recharge through an arid basin. 1993 International High-Level Radioactive Waste Management Conference, Las Vegas, NV, April 26-30, 1993.

Davis, J. C., I. D. Proctor, J. R. Southon, M. W. Caffee, D. W. Heikkinen, M. L. Roberts, K. W. Turtletaub, D. E. Nelson, D. H. Loyd, and J. S. Vogel. 1990. LLNL/UC AMS Facility and research program. Nuclear Instruments and Methods in Physics Research, Vol. B52, pp. 269-272.

Donaldson, R. E. and P. L. Sutherland. 1986. Total porosity. In: Klute, A. L. (ed), Methods of soil analysis, Part 1, Physical and mineralogical methods, 2nd Ed., American Society of Agronomy, Madison, WI, Chap. 18, pp. 444-445.

Dozier, B. L. and S. E. Rawlinson. 1991. Conceptual model for the geology in Area 5. DOE/NV/10630-14.

EG\&G/SAIC. 1991. Radiological performance assessment for the Area 5 Radioactive Waste Management Site at the Nevada Test Site. EG\&G Idaho, Inc. and Science Applications International Corporation (SAIC), Idaho Falls, ID.

Fenix and Scisson, Inc. 1987. Lithologic Descriptions of volcanic rocks. Memorandum GEO-0237.

Fenix and Scisson, Inc. 1990. The description of rock samples - Revision 1. Logging Procedure GPOO3.

Fernald, A. T., G. L. Dixon, W. J. Carr, and F. M. Byers, Jr. 1965. Geologic report on drill hole UE11a, Nevada Test Site. Technical Letter NTS-160. 
Freeze, R. A. and J. A. Cherry. 1979. Groundwater. Prentice-Hall, Inc., Englewood Cliffs, NJ.

Gee, G. W., M. D. Campbell, G. S. Campbell, and J. H. Campbell. 1992. Rapid measurement of low soil water potential using a water activity meter. Soil Sci. Soc. Am. J., Vol. 56, pp. 1068-1071.

Hammermeister, D. P., D. O. Blout, and J. C. McDaniel. 1986. Drilling and coring methods that minimize the disturbance of cuttings, core, and rock formations in the unsaturated zone, Yucca Mountain, Nevada, in Proceedings of the NWWA Conference on Characteri-zation and Monitoring of the Vadose (Unsaturated) Zone, Denver, CO, 1985, Worthington, OH, National Water Well Association, p. 507-541.

Hillel, D. 1980. Fundamentals of Soil Physics. Academic Press, New York.

Ingraham, N. L. and C. Shadel. 1992. A comparison of the toluene distillation and vacuum/heat methods for extracting soil water for stable isotope analysis. Journal of Hydrology, Vol. 140, pp. 371-387.

Jacobs, J. W., R. L. Korotev, D. P. Blanchard, and L. A. Haskins. 1977. A well-tested procedure for instrumental neutron activation analysis of silicate rocks and minerals. Journal of Radioanal. Chem. 40, pp. 93-114.

Katz, D. L., D. Comell, R. Kobayashi, F. H. Poettmann, J. A. Vary, J. R. Elenbaas, and C. F. Weinug. 1959. Handbook of natural gas engineering. McGraw-Hill, New York.

Klute, A. L. 1986. Water retention: Laboratory methods. In: Klute, A. L. (ed), Methods of soil analysis, Part 1, Physical and mineralogical methods, 2nd Ed., American Society of Agronomy, Madison, WI, Chap. 26, pp. 635-641.

Klute, A. L. and C. Dirksen. 1986. Hydraulic conductivity and diffusivity: Laboratory methods-Falling-head method. In: Klute, A. L. (ed), Methods of soil analysis, Part 1, Physical and mineralogical methods, 2nd Ed., American Society of Agronomy, Madison, WI, Chap. 28, pp. 700-703.

Los Alamos National Laboratory (LANL). 1991. Draft, Procedure for using ion chromatography to determine chloride and bromide concentrations. Los Alamos National Laboratory, Internal Report, LANL-INC-DP-94.RO, pp. 3-25.

Los Alamos National Laboratory (LANL). 1992. Sample leaching to extract soluble chloride and bromide. Los Alamos National Laboratory, Intemal Report, LANL-INC-DP-92.R0, pp. 3-15. 
Los Alamos Natio.sal Laboratory (LANL). 1993. Draft, Procedure, Preparation of samples for chlorine-36 analysis. LANL-INC-DP-95.R1. pp. 3-14.

Morris, G. A., D. Snoeberger, C. Morris, V. Du Val, 1971. Field measurements of permeability of NTS alluvium in Area 10. Lawrence Radiation Laboratory, UCID-15919.

Mualem, Y. 1976. A new model for predicting the hydraulic conductivity of unsaturated porous media. Water Resour. Res., Vol. 12, pp. 513-522.

Nelson, R. E. 1982. Carbonate and gypsum: pressure-calcimeter method. In: Page, A. L., R. H. Miller, and D. R. Keeney (eds). Methods of soil analysis, Part 2, Chemical and microbiological properties, 2nd Ed., American Society of Agronomy, Madison, WI, Chap. 11, pp. 188-192.

Norrish, K. and B. W. Chappell. 1977. X-ray fluorescence spectrometry. In: Zussman, J. (ed), Physical methods in determinative mineralogy, 2nd Ed., Academic Press, New York, pp. 210-272.

Norrish, K. and J. T. Hutton. 1969. An accurate X-ray spectrographic method for the analysis of a wide range of geochemical samples. Geochim. Cosmochim. Acta, Vol. 33, pp. $431-453$.

Pasternak, A. and E. T. McMullen. 1970. Field measurement of the permeability of NTS alluvium. Lawrence Radiation Laboratory, UCID-15727.

Phillps, F. M., J. L. Mattick, T. A. Duval, D. Elmore, and P. W. Kubick. 1988.

Chlorine-36 and tritium from nuclear weapons fallout as tracers for long-term liquid and vapor movement in desert soils. Water Resour. Res., Vol. 24, pp. 877-891.

Poole, F. G. 1965. Geologic map of the Frenchman Flat quadrangle, Nye, Lincoln and Clark Counties, NV. Map GQ-456, USGS.

REECo. 1993a. Hydrogeologic data for science trench boreholes at the Area 5 Radioactive Waste Management Site, Nevada Test Site, Nye County, Nevada. Special Projects Section, Environmental Management Division, Reynolds Electrical \& Engineering Co., Inc., Las Vegas, NV.

REECo. 1993b. Hydrogeologic data for existing excavations at the Area 5 Radioactive Waste Management Site, Nevada Test Site. Special Projects Section, Environmental Management Division, Reynolds Electrical \& Engineering Co., Inc., Las Vegas, NV.

Rozsa, R., D. Snoeberger, and J. Baker. 1975. Permeability of a nuclear chimney and surface alluvium, Area 2, ERDA, NTS. Lawrence Livermore Laboratory, UCID-16722. 
Snoeberger, D. F., J. Baker, C. J. Morris, and R. B. Rozsa. 1974. Permeability of a nuclear chimney and surface alluvium at the AEC Nevada Test Site. Lawrence Livermore Laboratory, UCID-16479.

Sully, M. J., D. E. Cawlfield, D. O. Blout, L. E. Barker, B. L. Dozier, and D. P. Hammermeister. 1993. Characterization of the spatial variability of hydraulic properties at the Area 5 Radioactive Waste Management Site. Submitted to DOE/NV for technical review on February 16, 1993.

Tabatabai, M. A. 1982. Sulfur: Inorganic sulfur. In: Page, A. L., R. H. Keeney (eds). Methods of soil analysis, Part 2, Chemical and microbiological properties, 2nd Ed., American Society of Agronomy, Madison, WI, Chap. 28, pp. 518-522.

Tyler, S. 1986. Moisture monitoring in large diameter boreholes, in Proceedings of the NWWA Conference on Characterization and Monitoring of the Vadose (Unsaturated) Zoize, Denver, CO, 1985, Worthington, OH, National Water Well Association, pp. 97-106.

USEPA. 1982. Methods for chemical analysis of water and wastes. EPA-600/4-82-055.

USEPA. 1986. EPA Method 9060. Total Organic Carbon. Test methods for evaluating solid waste (SW-846), Chapter 5, Miscellaneous Test Methods, 5 p.

USGS. 1990. Method for a thermistor calibration and testing in a USGS controlled temperature environment laboratory. USGS Technical Procedure NWM-USGS-HP-162, RO, Draft $9 / 10 / 90$.

USGS. 1993. Method for calibrating peltier-type thermocouple psychrometers for measuring water potentials of partially saturated media. USGS Technical Procedure NWM-USGS-HP. 14, R2.

van Genuchten, M. T. 1978. Calculating the unsaturated hydraulic conductivity with a new closed-form analytical model. Princeton University, New York.

van Genuchten, M. T. 1980. A closed-form equation for predicting the hydraulic conductivity of unsaturated soils. Soil Sci. Soc. Am. J., Vol. 45, pp. 892-898.

Winograd, I. J. and W. Thordarson. 1975. Hydrologic and hydrochemical framework, South-central Great Basin, Nevada-Califomia, with special reference to the Nevada Test Site. USGS Professional Paper 712-C. 

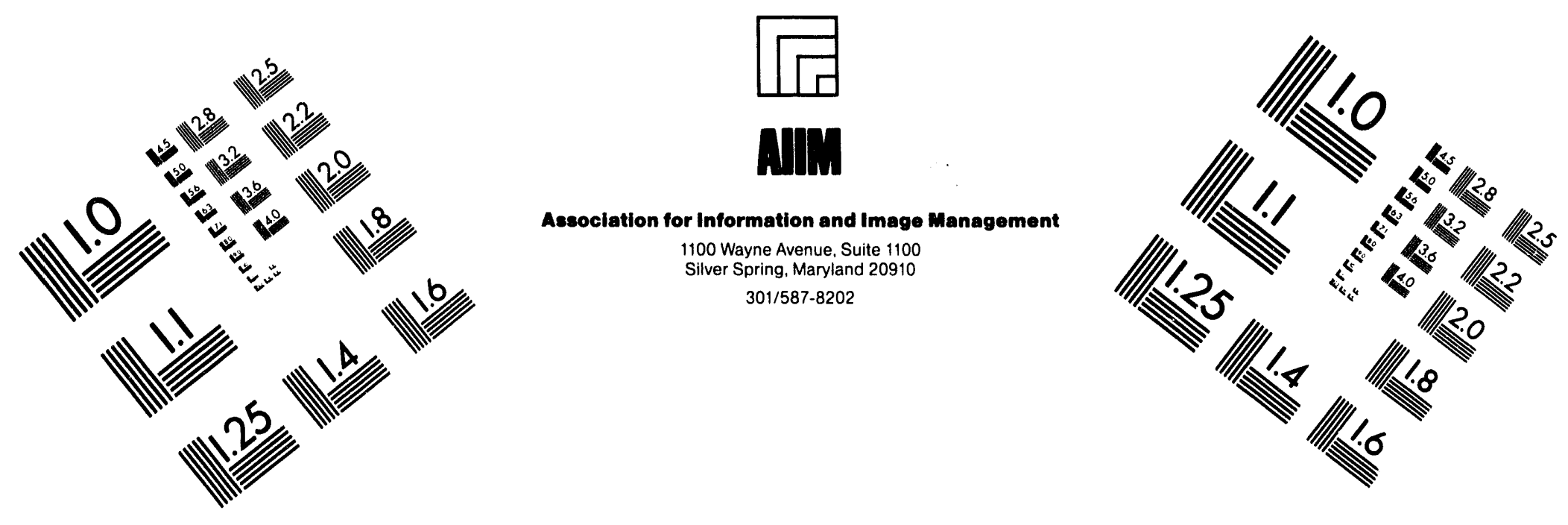

\section{Centimeter}

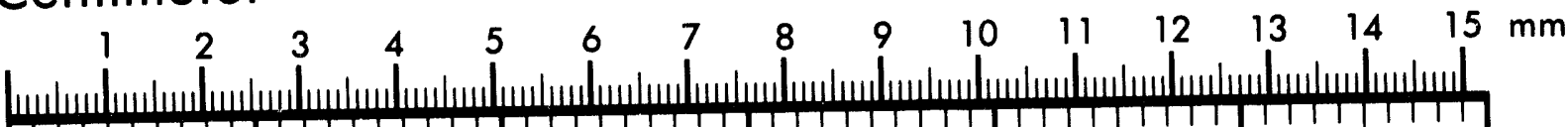

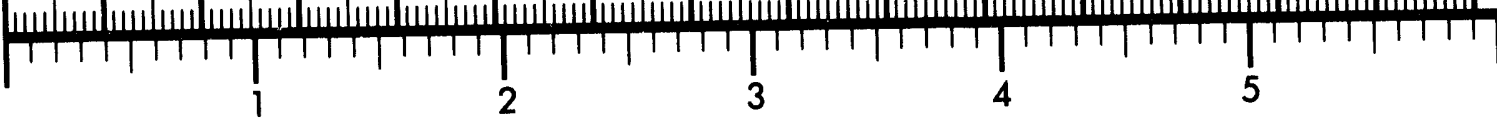
Inches
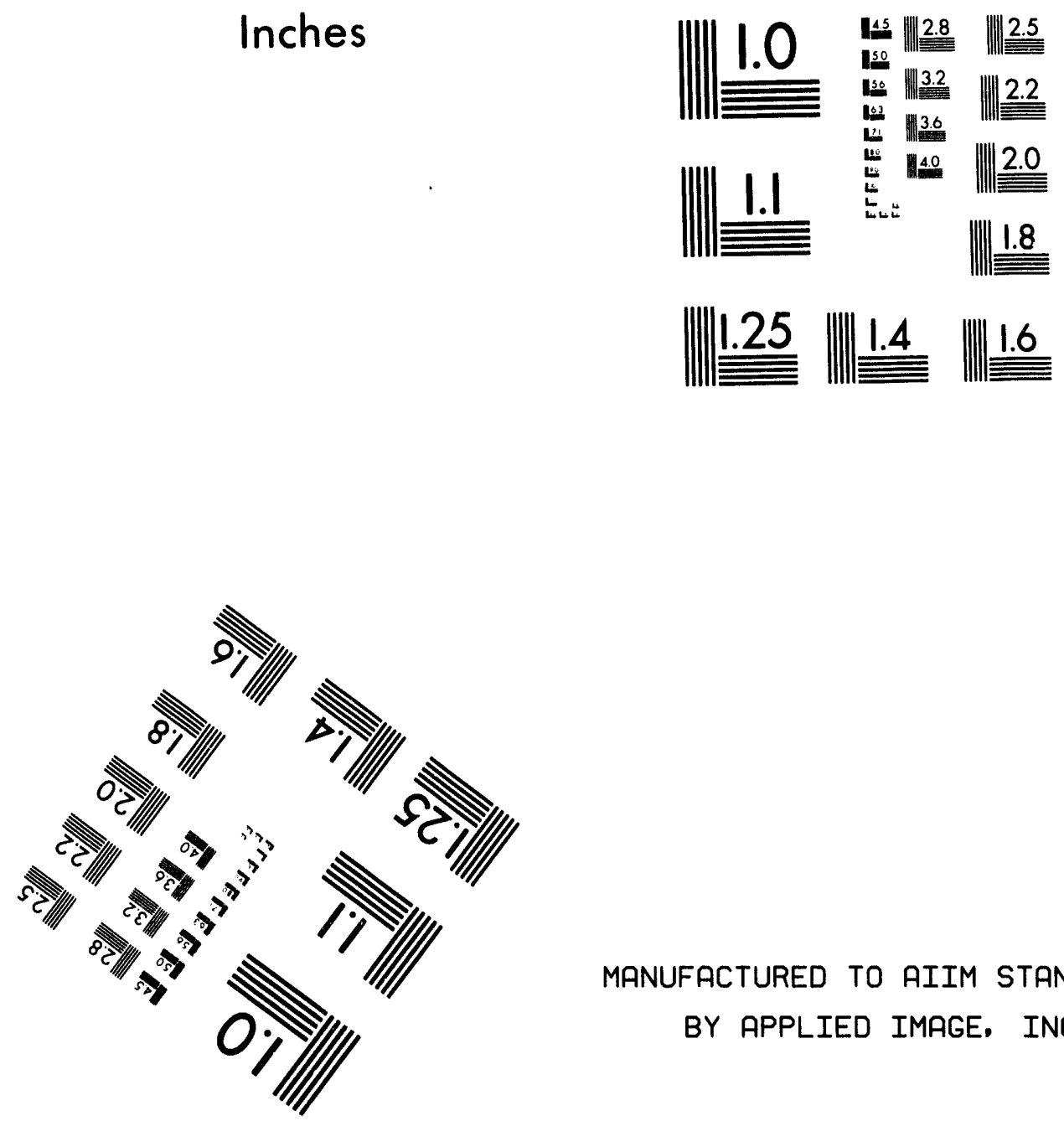

MANUFACTURED TO AIIM STANDARDS

$$
\text { BY APPLIED IMAGE. INC. }
$$

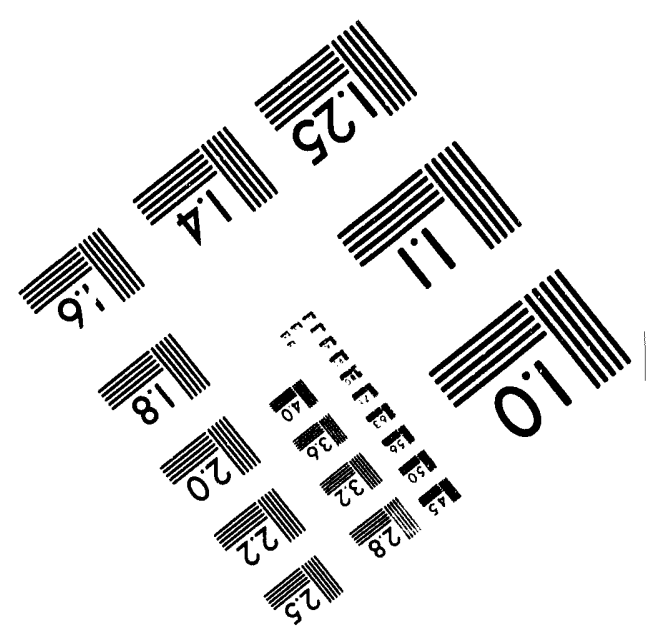



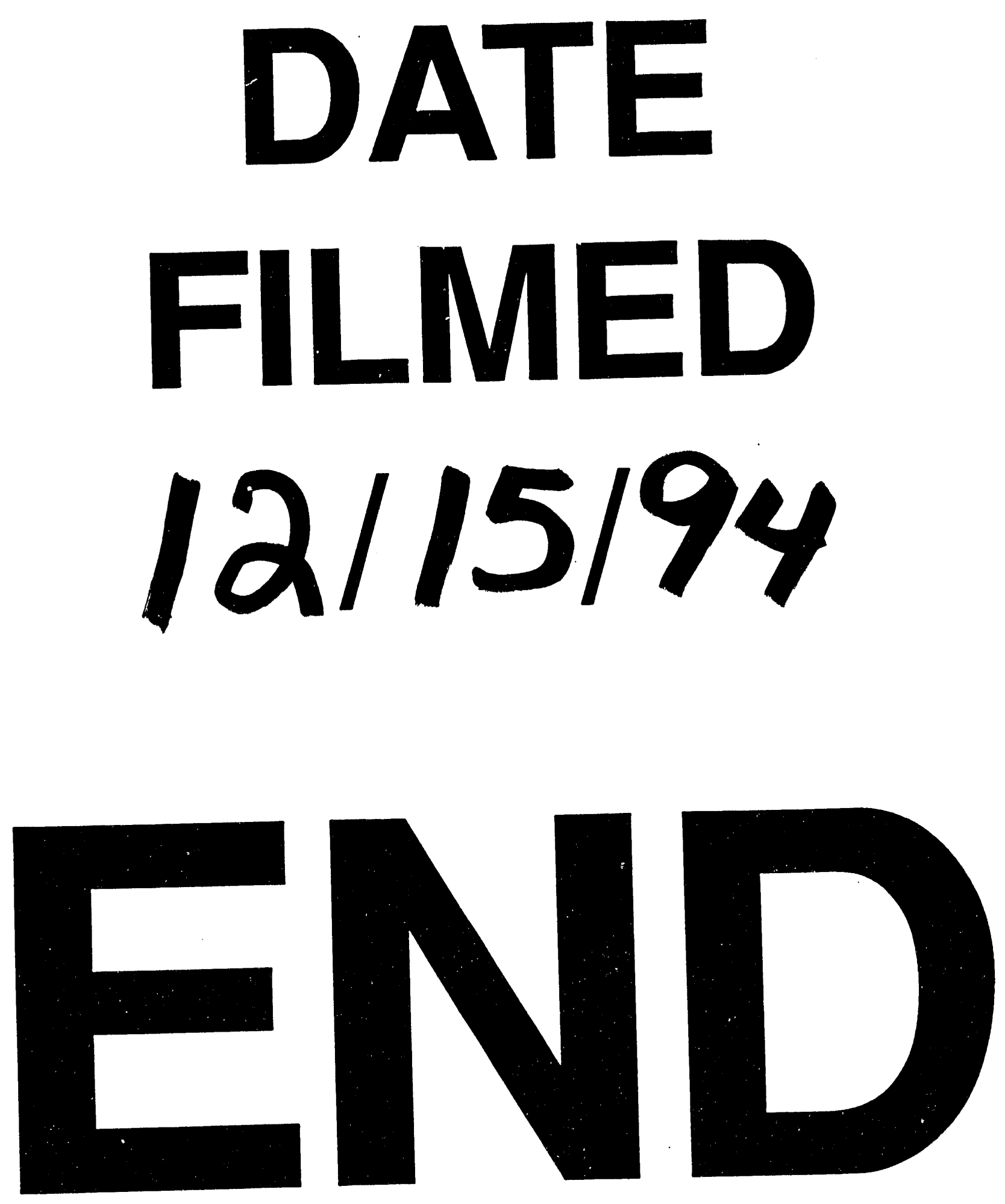